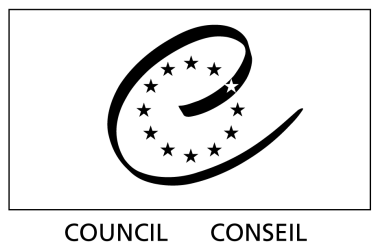

OF EUROPE DEL'EURO

Strasbourg, 23 September 2010

MIN-LANG/PR (2010) 7

European Charter for Regional or Minority Languages

Second periodical report

presented to the Secretary General of the Council of Europe

in accordance with Article 15 of the Charter

SERBIA 


\title{
The Republic of Serbia
}

\section{The European Charter for Regional or Minority Languages}

\author{
The Second Periodical Report \\ Submitted to the Secretary General \\ of the Council of Europe \\ Pursuant to Article 15 of the Charter
}

Belgrade, September 2010 


\section{CON T E N T S}

1. INTRODUCTION ................................................................6

2. Part I ................................................................................12

2.1. Legislative and institutional changes after the first cycle of monitoring of the implementation of the Charter ................................................ 12

2.1.1. Legislative changes ............................................. 12

2.1.2. The National Strategy for the Improvement of the Status of Roma ........17

2.1.3. Judicial Reform ..................................................17

2.1.4. Establishment of the Ministry of Human and Minority Rights ............23

2.2. Novelties expected during the next monitoring cycle of the implementation of the

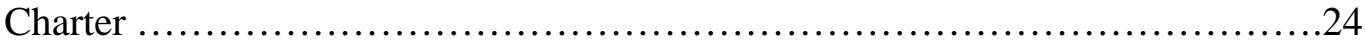

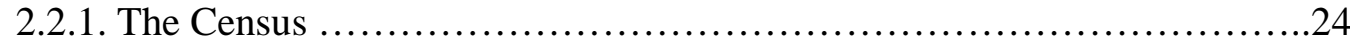

2.2.2. Election of the national councils of the national minorities ...............26

2.3. Implementation of the recommendations of the Committee of Ministers of the

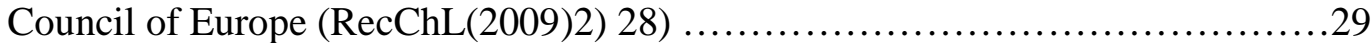

2.4. Activities for the implementation of the box-recommendation of the Committee of Experts with regard to the implementation of the Charter .......................33

3. PART II Implementation of Article 7 of the Charter ..............................38

3.1. Information on the policy, legislation and practice in the implementation of Part II -

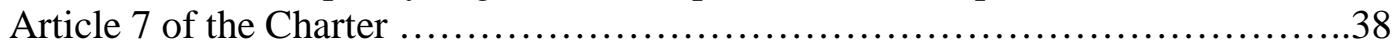

3.1.1. Recognition of minority languages as cultural wealth ...................39

3.1.2. Respect for the geographical areas of minority languages ................40

3.1.3. Resolute action to promote minority languages .........................40

3.1.4. Provision of conditions to facilitate and promote the use of minority languages .......................................................41

3.1.5. Establishment of cultural links between the groups speaking minority languages ......................................................4 41

3.1.6. Provision of the study of minority languages .........................41

3.1.7. Facilitation of the study of minority languages ........................41

3.1.8. Promotion of the studies and research of minority languages at universities ..................................................49

3.1.9. Promotion of trans-national exchange ..............................49

3.1.10. Elimination of unfavourable treatment of use of minority languages and adoption of special measures in favour of minority languages ..........52

3.1.11. Promotion of mutual understanding between all language groups ........54

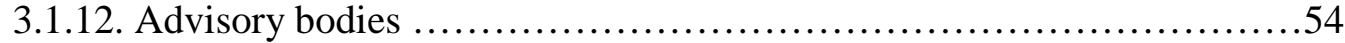

3.2. Information on the implementation of the Charter for Minority Languages for which obligations from Part III of the Charter are not taken over ....................54

3.2.1. Bunjevac speech ...............................................54

3.2.2. Vlach language .................................................. 57

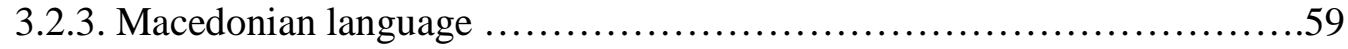

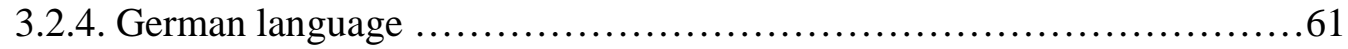

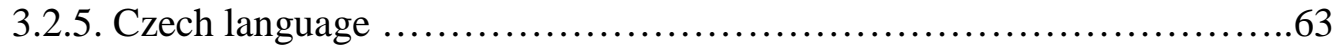


3.3. Activities for the implementation of box-recommendation of the Committee of Experts related to Article 7 of the Charter ..................................65

3.3.1. Information on the practical use of Czech language by the administrative authorities and at the Municipal Court of Bela Crkva

3.3.2. Information on the structured policy for the protection and promotion of Vlach language .................................................66

3.3.3. Information on the activities to provide for the teaching of PART II languages of the Charter ........................................67

3.3.4. Information on the activities to promote awareness and tolerance vis-à-vis the minority languages and the cultures they represent ................67

3.3.5. Information on provision of a stable legal basis for the functioning of national minority councils and magistrate meetings of the Republic of Serbia Council for National Minorities ................................72

\section{PART III IMPLEMENTATION OF MEASURES TO PROMOTE USE OF MINORITY LANGUAGES IN ACCORDANCE WITH THE OBLIGATIONS CONTAINED IN ARTICLE 2 PARAGRAPH 2 OF THE CHARTER ............75}

4.1. Article 8 -Education .......................................................75

4.1.1. Legislative changes of relevance for the implementation of Article 8 of the

Charter ......................................................... 76

4.1.2. Pre-School education ............................................ 79

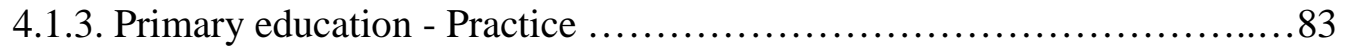

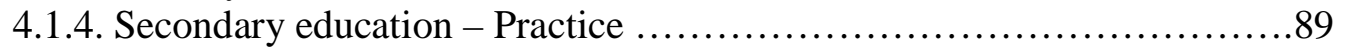

4.1.5. Technical and vocational education - Practice .......................992

4.1.6. University education - Practice ....................................99

4.1.7. Adult education -Practice ....................................... 100

4.1.8. Activities for the implementation of box-recommendation of the Committee of Experts concerning Article 8 of the Charter .....................100

4.2. Article 9 - Judicial Authorities ................................................102

4.2.1. Legislation relevant for the implementation of Article 9 of the Charter ..103

4.2.2. Criminal proceedings ............................................... 103

4.2.3. Civil proceedings ..............................................106

4.2.4. Administrative disputes .......................................110

4.2.5. Activities for the implementation of box-recommendation of the Committee of Experts concerning Article 9 of the Charter .......................111

4.2.5.1. Information to citizens about the possibility of using minority languages in courts ..............................................111

4.2.5.2. Availability of the most important statutory texts in minority languages ................................................. 112

4.3. Article 10 - Administrative Authorities and Public Services ..................113

4.3.1. Submission of applications in minority languages to the state administration bodies .......................................................114

4.3.2. Submission of applications in minority languages to local or regional authorities ................................................ 114

4.3.3. Publishing of regional documents in minority languages ...............117

4.3.4. Publishing of local documents in minority languages .................118 
4.3.5. Use of traditional forms of place names in minority languages ..........119

4.3.6. Submission of applications to public services in minority languages ....125

4.3.7. Engagement of speakers of minority languages in public services ......127

4.3.8. Use and adoption of family names in minority languages ..............127

4.3.9. Activities for the implementation of box-recommendations of the Committee of Experts concerning Article 10 of the Charter ............129

4.3.9.1. Activities to ensure submission of oral and written applications to State authorities in minority languages ............................129

4.3.9.2. Activities to ensure the publication of official documents in minority languages ............................................. 129

4.4. Article 11 - Media .........................................................131

4.4.1. Novelties after the first cycle of monitoring of the implementation of the Charter .........................................................132

4.4.1.1. Broadcasting licences for radio and TV programmes ...........132

4.4.1.2. Measures for resolution of media issues ......................133

4.4.2. Public broadcasting agencies ...................................... 134

4.4.3. Encouragement and facilitation of radio in minority languages..........137

4.4.4. Encouragement and facilitation of television programmes in minority

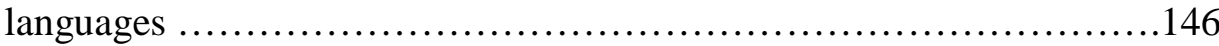

4.4.5. Encouragement and facilitation of production and distribution of audio and audio-visual works in minority languages .........................151

4.4.6. Encouragement or facilitation of establishment and preservation of at least one newspaper in minority languages ............................ 154

4.4.7. Representation of the interests of users of minority languages ...........166

4.4.8. Activities for the implementation of box-recommendation of the Committee of Experts concerning Article 11 of the Charter .............167

4.5. Article 12 - Cultural Activities and Facilities ......................................169

4.5.1. Encouragement of expression and access to works in minority

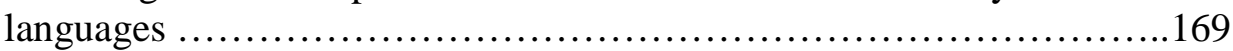

4.5.1.1. Libraries ............................................171

4.5.1.2. Cultural clubs, cultural centres and cultural institutes ..........173

4.5.1.3. Protection of cultural goods (cultural monuments, museums and archives) ...................................................174

4.5.1.4. Theatres ............................................... 176

4.5.1.5. Publishing (literary works) ..............................182

4.5.1.6. Cultural manifestations ...................................193

4.5.2. Encouragement of access to works produced in minority languages ......201

4.5.3. Promotion of access of minority languages to works produced in other languages .................................................203

4.5.4. Encouragement of direct participation of the users of minority languages in provision of the conditions and planning of cultural activities .........204

4.5.5. Encouragement and provision of cultural activities in the territories different from those where minority languages are not

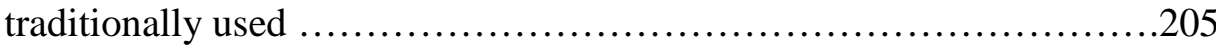

4.6. Article 14 - Trans-National Exchanges.....................................206

4.6.1. Application of bilateral and multilateral arrangements ..................206 
4.6.2. Facilitation and improvement of co-operation between regional and local authorities .......................................................206

5. SUPPLEMENTS ..............................................................209

5.1. Supplement of the National Council of the Bosniak National Minority ...209

5.2. Supplement of the National Council of the Bunjevac National Minority ..216

5.3. Supplement of the National Council of the Romanian National Minority ..219 


\section{INTRODUCTION}

1. Pursuant to the provision of Article 15 of the European Charter on Regional or Minority Languages (hereinafter referred to as the Charter), which is ratified with the Law on Ratification of European Charter on Regional or Minority Languages (the Official bulletin of Serbia and Montenegro - International Treaties, no. 18/05), the Republic of Serbia submits the Second Periodical Report within the period from 2007-2009, conducted in accordance with the Revised Draft for Periodical Reports (MIN-LANG (2009) 8), which was adopted at the $1056^{\text {th }}$ meeting of the Committee of Ministers of the Council of Europe held on 6 May 2009.

2. The Second Periodical Report on the implementation of the Charter was prepared by the Ministry of Human and Minority Rights. The following state bodies took part in the development of the Report: the Ministry of Culture, the Ministry of Education, the Ministry of Justice, the Ministry of Public Administration and Local Self-Government, the Ministry of Foreign Affairs, the Department for Legislature, as well as the provincial authorities of the Autonomous Province of Vojvodina: The Provincial Secretariat for Regulations, Administration and National Minorities, the Provincial Secretariat of Information, the Provincial Secretariat of Education and the Provincial Secretariat of Culture.

3. The following institutions were consulted in the compilation of the Report: The Jablanica Administrative District, the South Bačka Administrative District, the South Banat Administrative District, the Pčinjski Administrative District, the Pirot Administrative District, the Raška Administrative District, the North Bačka Administrative District, the North Banat Administrative District, the Middle Banat Administrative District, the Srem Administrative District, the West Bačka Administrative District and the Zlatibor Administrative District. The following local self-governments took part in the compilation of this Report - Ada, Aleksinac, Alibunar, Apatin, Bačka Palanka, Belgrade, Bečej, Bujanovac, Valjevo, Vladičin Han, Vlasotince, Vrbas, Dimitrovgrad, Doljevac, Žabalj, Žitište, Zrenjanin, Kanjiža, Kikinda, Kovin, Kragujevac, Lebane, Leskovac, Medveđa, Niš, Novi Bečej, Novi Pazar, Novi Sad, Odžaci, Pančevo, Pirot, Plandište, Požarevac, Preševo, Prijepolje, Senta, Sečanj, Sjenica, Smederevo, Sremska Mitrovica, Subotica, Surdulica, Titel, Šabac and Šid and Telekom Srbija a.d., Elektroprivreda Srbije and PTT Srbija public companies. The Statistical Institute of the Republic of Serbia, the Republic Broadcasting Agency and the Serbian Business Registers Agency participated and were consulted in the compilation of this Report. The High Judicial Council and the following courts took part in compilation of this Report: the Magistrate Courts in Vršac, Zrenjanin, Leskovac, Pančevo, Pirot, Sombor and Subotica, the High Courts in Leskovac, Novi Pazar, Novi Sad, Pančevo, Pirot, Sremska Mitrovica, Subotica, Užice and the Administrative Court in Belgrade. 
4. Contribution to the compilation of the Report were given by the following cultural institutions: the Institute of the Culture of the Hungarians of Vojvodina, the Institute of the Culture of the Slovaks of Vojvodina and by the following libraries: the Savraš Gabor Library in Ada, the Public Library in Apatin, the Public Library in Babušnica, the Vuk Karadžić Public Library in Bač, the Veljko Petrović Public Library in Bačka Palanka, the Public Library in Bačka Topola, the Štefan Homola Library in Bečej, the Public Library in Bor, the Hristov Botev Public Library in Bosilegrad, the 14th November Public Library in Bujanovac, the Danilo Kiš Public Library in Vrbas, the Town Library in Vršac, the Detko Petrov Public Library in Dimitrovgrad, the Public Library in Žagubica, the Branko Radičević in Žitište, the Žarko Zrenjanin Town Library in Zrenjanin, the Dr.Đorđe Natošević Public Library in Inđija, the Jožef Atila Library in Kanjiža, the Jovan Popović Public Library in Kikinda, the Municipal Library in Kovačica, the Vuk Karadžić Library in Kovin, the Public Library in Kula, the Petar Petrović Njegoš Municipal Library in Medveđe, the Stevan Sremac Public Library in Niš, the Dositej Obradović Public Library in Novi Pazar, the Town Library in Novi Sad, the Library of Matica Srpska in Novi Sad, the Town Library in Pančevo, the Public Library in Pirot, the Public Library in Plandište, the Town Library in Priboj, the Vuk Karadžić Library in Prijepolje, the Town Library in Senta, the Karlo Bijelicki Town Library in Sombor, the Gligorije Vozarević, Sremska Mitrovica, the Dositej Obradović Public Library, Stara Pazova, the Sirmai Karolj Library in Temerin, the Dr Ejup Mušović Public Library in Tutin and the Simeon Piščević Public Library in Sid; the publishing houses - the Magyar Szó in Novi Sad, the Zenta in Senta, the Ruske slovo in Novi Sad, the Hlas L'udu in Novi Sad, the Slovak Publiching Centre in Backi Petrovac and the Hrvatska Riječ in Subotica; Media the Republic and Provincial Public Service, RTV Bujanovac, RTV Valjevo, RTV Vrbas, RTV Viktorija, Vršac, RTV Caribrod, Dimitrovgrad, RTV Inđija, RTV Kruševac, RTV Kovačica, RTV Krajina, Negotin, RTV Nišava, Niš, RTV Pančevo, RTV Aldi,Preševo, RTV Panon, Subotica, RTV YU ECO, Subotica, RTV Trstenik, Radio Ada,Radio Far, Alibunar, Radio Bačka, Bač, Radio Trend, Bačka Topola, Radio Regije, Bačka Topola, Radio Bački Petrovac, Radio Bela Crkva, Radio Bosilegrad, Radio Ema, Bujanovac, Radio Zrenjanin, Panda Radio, Kanjiža, Radio Kikinda, Radio Bus, Kovin, RaDio Zenit, Kula, Radio Novi Bečej, Radio Kisač, Novi Sad, Radio Blue, Odžaci, Radio BluePlus, Odžaci, RAdio Odžaci, Radio Sečanj, Radio Sombor, Radio Srbobran, Radio Subotica, Radio Stara Pazova, Radio Temerin, Bosniak Radio, Tutin, Radio Šid, TV Petrovac, Bački Petrovac, Regional TV Novi Pazar, TV Mozaik, Novi Sad, TV Odžaci, TV ForUM, Prijepolje, TV Tutin and Sremska TV, Šid.

5. Although all national councils of the national minorities were invited to participate in the compilation of this Report, the National Council of the Bosniak National Minority, the National Council of the Bunjevac National Minority and the National Council of the Romanian National Minority only responded and their reports are presented in the supplements making an integral part of this Report. Around thirty relevant minority NGO's were invited but only four of them responded: the Paulj Matejić Vlach Community, the Vardar Civic Association of 
the Macedonian National Minority of the South Banat District, the Association for the Ruthenian Language, Literature and Culture and the Matica Češka.

6. The following national regulations were used in this Report:

Constitutional law, criminal law, the judiciary, state and public administration

- The Constitution of the Republic of Serbia (the Official Gazette of RS, no. 98/06)

- The Statute of the Autonomous Province of Vojvodina (the Official Gazette of APV, no. 17/91)

- The Statute of the Autonomous Province of Vojvodina (the Official Gazette of APV, no. 17/09)

- The Law on the Establishment of Specific Competences of AP Vojvodina (the Official Gazette of RS, nos. 6/02, 101/07 - other law, 51/09 - other law)

- The Law on the Establishment of Specific Competences of AP Vojvodina (the Official Gazette of RS, no. 99/09 - in force since 1 January 2010

- The Law on Prohibition of Discrimination (the Official Gazette of the RS, no. 22/09)

- The Law on Protection of Rights and Freedoms of National Minorities (the Official Gazette of FRY, no.11/02 and the Official Gazette of RS, no. 72/09 other law)

- The Law on the National Councils of the National Minorities (the Official Gazette of the Republic of Serbia, no. 72/09)

- The Decree on Establishment of the Council of National Minorities (the Official Gazette of RS, no. 50/09)

- The Law on Official Use of Languages and Scripts (the Official Gazette of RS, nos. 45/91, 53/93 - other law, 67/93 - other law, 48/94 - other law, 101/05, other law and 30/10)

- The Decision on More Specific Regulation of Certain Issues concerning Official Use of Languages and Scripts of National Minorities in the Territory of the Autonomous Province of Vojvodina (the Official Gazette of APV, nos. 8/03 and 9/03)

- The Criminal Procedure Code (the Official Gazette of FRY, nos. 70/01 and 68/02, the Official Gazette of RS, nos. 58/04, 85/05,115/05, 49/07, 122/08 - other law, 20/09 - other law and 72/09)

- The Law on Litigation (the Official Gazette of RS, nos. 125/04 and 111/09)

- The Law on General Administrative Procedure (the Official Gazette of FRY, nos. 33/97, 31/01 and the Official Gazette of RS, no. 30/10)

- The Law on Administrative Disputes (the Official Gazette of RS, no. 111/09)

- The Law on High Judicial Council, (the Official Gazette of the RS, no.116/08)

- The Law on Organization of Courts (the Official Gazette of RS, nos. 116/08 and 104/09)

- The Law on High Judicial Council (the Official Gazette of RS, no.116/08)

- The Law on Judges (the Official Gazette of RS, nos. 116/08, 58/09 - US and 104/09) 
- The Law on Public Prosecutor (the Official Gazette of the RS, nos.116/08 and 104/09)

- The Law on Seats and Territorial Jurisdiction of Courts and Public Prosecutor (the Official Gazette of RS, no. 116/08

- The Law on Territorial Organization of the Republic of Serbia (the Official Gazette of RS, no. 129/07)

- The Law on Local Self-Government (the Official Gazette of RS, no.129/07)

- The Law on Registers of Births, Marriages and Deaths (the Official Gazette of RS, no. 20/09)

- Instruction on Administration and Forms of Registers of Births, Marriages and Deaths (the Official Gazette of RS, nos. 109/09, 4/10 - correction and 10/10)

- The Law on Political Parties (the Official Gazette of RS, no. 36/09)

- The Law on Associations (the Official Gazette of RS, no. 51/09)

- The Law on Ministries (the Official Gazette of the RS, nos. 65/08 and 36/09 other law)

- The Law on Maximum Number of Employees in Local Administration (the Official Gazette of the RS, no. 104/09)

- The Law on Population Census, Households and Flats in 2011 (the Official Gazette of the RS, no. 104/09)

- The Decision on More Specific Regulation of Certain Issues concerning Official Use of Languages and Scripts of National Minorities in the Territory of the Autonomous Province of Vojvodina (the Official Gazette of APV, nos. 8/03, 9/03 and 18/09 - Documents Title Changes)

- The Provincial Decision on the Provincial Administration of Vojvodina (the Official Gazette of APV, no. 4/10)

- The Provincial Decision on the Government of the Autonomous Province of Vojvodina (the Official Gazette of APV, no. 4/10)

\section{Education}

- The Law on Basic Principles of the Educational System (the Official Gazette of RS, nos. 62/03, 64/03, 58/04, 62/04) - which was revoked on 11 September 2009

- The Law on Basic Principles of the Educational System (the Official Gazette of RS, no. 72/09)

- The Law on Primary Education (the Official Gazette of RS, nos. 50/92 and 22/02)

- The Law on Secondary Schools (the Official Gazette of RS, nos. 50/92, 24/96, 23/02 and 25/02)

- The Law on Higher Education (the Official Gazette of RS, nos. 76/05 and 97/08)

- The Law on Textbooks and Other Teaching Materials (the Official Gazette of RS, no.72/09)

- The Law on Pre-school Education (the Official Gazette of RS, no.18/10)

- The Strategy of Professional Training Development in the Republic of Serbia (the Official Gazette of RS, no.1/07)

\section{Culture}


- The Law on Activities of the Public Interest in the Field of Culture (the Official Gazette of RS, no. 49/92) - was revoked on 11 March 2010

- The Law on Culture (the Official Gazette of the Republic of Serbia, no. 72/09) applied since 11 March 2010)

- The Law on Librarianship (the Official Gazette of RS, no. 34/94)

- The Decision on the Foundation of the Institute for the Culture of Vojvodina (the Official Gazette of APV, nos. 10/03 and 8/06)

- The Decision on the Foundation of the Institute for the Culture of Vojvodina Hungarians (the Official Gazette of APV, no. 7/08)

- The Decision on the Foundation of the Institute for the Culture of Vojvodina Romanians (the Official Gazette of APV, nos. 7/08 and 3/10)

- The Decision on the Foundation of the Institute for the Culture of Vojvodina Ruthenians (the Official Gazette of APV, no. 7/08)

- The Decision on the Foundation the Institute for the Culture of Vojvodina Slovaks (the Official Gazette of APV, nos. 7/08 and 6/09)

- The Decision on the Foundation the Institute for the Culture of Vojvodina Croats (the Official Gazette of APV, nos. 7/08 and 6/09)

\section{Media}

- The Public Information Law (the Official Gazette of RS, nos. 43/03, 61/05 and 71/09)

- The Broadcasting Law (the Official Gazette of RS, nos. 42/02, 97/04, 76/05, $62 / 06,85 / 06,86 / 06$ and 41/09)

\section{Economic and Social Life}

- The Family Law (the Official Gazette of RS, no. 18/2005)

The Republic of Serbia is the successor to bilateral agreements on the protection of national minorities, which also regulate the use of minority languages in part.

- Agreement between Serbia and Montenegro and the Republic of Hungary on the Protection of Rights of the Hungarian National Minority Living in Serbia and Montenegro and of the Serbian National Minority Living in the Republic of Hungary (the Official Bulletin of Serbia and Montenegro - International Treaties, no. $14 / 04)$

- The Agreement between Serbia and Montenegro and the Republic of Macedonia on the Protection of the Serbian and Montenegrin National Minorities in the Republic of Macedonia and of the Macedonian National Minority in Serbia and Montenegro (the Official Bulletin of Serbia and Montenegro - International Treaties, no. 6/05)

- The Agreement between the Federal Government of the Federal Republic of Yugoslavia and the Government of Romania on Cooperation in the Field of the Protection of National Minorities (the Official Gazette of FRY - International Treaties , no. 14/04)

- The Agreement between Serbia and Montenegro and the Republic of Croatia on the Protection of Rights of the Serbian and Montenegrin Minorities in the 
Republic of Croatia and the Croatian Minority in Serbia and Montenegro (the Official Bulletin of Serbia and Montenegro - International Treaties, no. 3/05)

The Republic of Serbia is the successor to bilateral agreements on co-operation in the fields of culture and education, which are of relevance to minority languages:

- Agreement between Serbia and Montenegro and the Republic of Hungary on Cooperation in the Fields of Education, Culture, Youth and Sports (the Official Gazette of RS - International Treaties, no. 38/09)

- The Agreement on Co-operation in the Fields of Education, Culture and Sports between the Federal Government of FR Yugoslavia and the Government of the Slovak Republic( the Official Gazette of FRY - International Treaties, no. 4/96)

- The Agreement on Co-operation in the Fields of Education, Culture and Sports between the Federal Government of FR Yugoslavia and the Government of the Ukrainian (the Official Gazette of FRY - International Treaties, no. 4/96)

- The Agreement between the Federal Government of FR Yugoslavia and the Government of the Republic of Croatia (the Official Gazette of FRY International Treaties, no. 12/02)

7. In order to avoid unnecessary repetitions, the data on the financial support by the state contained in the Tables of the Report relate to the period of three years (2007-2009), unless indicated otherwise and these data are expressed in dinars. For the purpose of harmonization of the terms used with the Charter, the following expressions are used in the Report: minority language is the synonym for national minority language and user or minority language speaker as the synonym of a national minority member.

8. All expressions used in this Report in male gender also include the same expressions in female gender. 


\section{PART I}

\subsection{Legislative and institutional changes after the first cycle of monitoring of the implementation of the Charter}

\subsubsection{Legislative changes}

9. Within the period after the first monitoring cycle of the implementation of the Charter, a series of regulations containing the provisions of importance for the use and protection of minority languages has been adopted in the Republic of Serbia. The following paragraphs of this section give a review of those regulations, whereas their contents shall be explained in details in certain parts of the Report.

10. The Law on Prohibition of Discrimination, which was adopted in 2009, elaborates in details the prohibition of discrimination by the constitution, prescribes general prohibition of discrimination, forms and cases of discrimination, as well as the procedures for protection against discrimination and establishment of the Commissioner for protection of gender equality, as an independent state body, which is independent in the performance of jobs established by this law. The Law prescribes prohibition of discrimination of national minorities and the members of national minorities based on language, whereas incitement and encouragement of non-equality, hatred and intolerance are qualified as severe forms of discrimination, inter alia, on language basis.

11. The Law on the National Councils of the National Minorities, which was adopted in 2009, represents further elaboration of the Law on Protection of the Rights and Freedoms of National Minorities concerning the issues of competence and election procedure of national councils of national minorities, through which national minorities accomplish the right to self-government in the field of use of language and script, education, information and culture. This Law governs the competences of national councils of national minorities in the above mentioned fields, the relation with state bodies, bodies of autonomous provinces and with local self-government units, election procedure of national councils, financing of activities of national councils and other issues of importance for the activities of national councils.

12. The Law on Local Self-Government, which was adopted in 2007, regulates the units of local self-government, criteria of their establishment, competence, bodies, supervision over their acts and activities, protection of local self-government and other issues of importance for the accomplishment of rights and duties of the units of local self-government. A municipality is the basic territorial unit in which local self-government is accomplished, which is capable to exercise independently through its bodies all the rights and duties within its competence and which has at least 10,000 inhabitants (Article 18 of the Law). Article 20 prescribes competences of a municipality, among which in item 33 of the same Article it is prescribed that a municipality, through its bodies, in accordance with the 
Constitution and law, shall establish minority languages and scripts in official use in its territory, which are established in the statute of the municipality.

13. The Law on Fundamentals of Educational System, which was adopted in 2009, prescribes the bases of the system of pre-school, primary and secondary education, prepares legal support to the reform of educational system together with the reform of university education and introduces teaching assistants into the educational system at all schools. The mission of the teaching assistant is to render assistance and additional support to children and pupils, in compliance with their requirements as well as to render assistance to teachers, child minders and experts associates in order to promote their work with children and pupils who need additional educational support (which is of particular significance for the children and pupils of the Roma national minority). Article 9 paragraph 2 prescribes that education-teaching for the members of national minorities is carried out in their mother tongue. In exceptional cases it may be carried out bilingually or in Serbian language, in accordance with a special law.

14. The Law on Culture, which was adopted in August 2009, has been in force since 11 March 2010. According to this law the national councils of national minorities are given a possibility to take care of the implementation of the cultural policy of national minorities and, pursuant to law, to participate in the decision making process or to decide on their own on certain issues concerning their culture, to establish cultural institutions and other legal entities in culture (Article 5). Concerning the establishment of the National Council of Culture, which is established as an expert-consulting body, for the purpose of provision of permanent expert support to maintenance, development and spreading of culture (Article 15), two members of national minorities are elected under the proposal of national councils of national minorities (Article 16 Paragraph 2 Item 7). The Republic of Serbia, the Autonomous Province and the unit of local selfgovernment may establish institutions to preserve, promote and develop cultural specificies and to preserve national identity of national minorities, namely, they may, under the proposal of the national council of national minority, by amending the document on incorporation for certain existing institutions define that such institutions are of particular importance for preservation, promotion and development of cultural specificies and preservation of national identity of national minorities (Article 24 Paragraph 1). Also, the board of directors of the institution being established in accordance with the mentioned Article of this law, must include at least one member of the board elected under the proposal of the relevant national council of national minority. If several national councils of national minorities propose some member of the board of directors, this proposal is to be jointly submitted by all interested national councils of national minorities (Article 42 Paragraph 3). If it is about the supervision board of the institution, at least one member of the supervision board is to be elected under the proposal of the relevant national council of national minority (Article 46 Paragraph 2). An artist, namely an expert in culture who had supremely contributed to the national culture by his/her activities in the field of culture, namely who had contributed to 
culture of national minorities in the Republic of Serbia and who meets other requirements prescribed by this law and regulations adopted to implement this law, may gain the status of a distinguished artist, namely the status of a distinguished expert in culture (Article 68).

15. In the course of 2009 another two laws were also adopted, which forward and affirm the use of minority languages. The Law on Political Parties defines the notion of a political party of some national minority (Article 3), and pursuant to this, the use of the name of a political party of some national minority in minority language as well (Article 18 Paragraph 2). This Law prescribes that the name of a political party of some national minority, if stipulated by the statute, may also be in the minority language and script, and that it is to be entered in the Registry of Political Parties after its name in Serbian and Cyrillic script. The Law on Associations contains a provision prescribing that the name of an association, if prescribed by the statute, may also be in minority language and script. The name in minority language and script is entered in the Registry of Associations after its name in Serbian and Cyrillic script (Article 13 Paragraph 4).

16. The Law on the Establishment of Competence of the Autonomous Province of Vojvodina, which was adopted in 2009, and has been in force since 1 January 2010, prescribes that the AP of Vojvodina, through its bodies, shall define in more details and secure the accomplishment of the rights of national minorities in the territory of AP of Vojvodina to education in mother tongue, at all educational levels, in accordance with the Law (Article 38); it prescribes the needs and the interest of national minorities in the field of culture and secures funds for their accomplishment (Article 41 Item 2); it provides a part of funds or other conditions for the operations of public media in minority languages in order that national minorities accomplish their right to information in their mother tongue and cherish their own cultures and identity (Article 62 Item 3); it prescribes in more details the official use of minority languages and scripts in the territory of AP of Vojvodina, pursuant to the law and also performs supervision (Article 76 Paragraphs 1 and 2).

17. The Statute of the Autonomous Province of Vojvodina in Article 7 stipulates that multi-linguistic, multi-cultural and multi-religious properties present a general value of particular importance for AP of Vojvodina. All provincial bodies and organizations have the duty, within the framework of their rights and obligations, to encourage and help to maintain and develop multi-linguistic and cultural heritage of national minorities traditionally living in AP of Vojvodina, as well as to promote mutual respect and learning of different languages, cultures and religions in AP of Vojvodina through special measures and activities. The Statute expands the scope of languages in official use in the operations of bodies and organizations of the Autonomous Province of Vojvodina for another language.

Namely, $\quad$ Article $\quad 26 \quad$ paragraph 1 http://www.puma.vojvodina.gov.rs/dokumenti/zakoni/Statut APV 2009.pdfregul ates that in addition to Serbian language and Cyrillic script, Hungarian, Slovak, 
Romanian and Ruthenian languages and their scripts, which have already been officially used, Croatian language is also officially used, which was only officially used in the activities of the Assembly of the Autonomous Province of Vojvodina. Paragraph 3 of this Article defines that the right to official use of minority languages not stated otherwise, is accomplished in accordance with ratified international treaties, laws and by the decision of the Provincial Assembly.

18. The Law on Amendments and Supplements to the Law on the Official Use of Language and Script, which was adopted in 2010, made co-ordinations with the Constitution, and it simultaneously made co-ordination with international treaties and the Law on Protection of Rights and Freedoms of National Minorities. The amendment of the provision of Article 1 of this Law prescribes, pursuant to Article 10 paragraph 1 of the Constitution of the Republic of Serbia, that Serbian language and Cyrillic script are in the official use in the Republic of Serbia. The amendment of Article 7 and Article 11 of this Law, made the co-ordination of the text of the law with the recognized Framework Convention on Protection of Rights of National Minorities (Article 11 paragraph 3). In this sense, the provision of Article 7 paragraph 3 of this Law was deleted, according to which geographic names and personal names contained in public notifications could not be replaced with other names, and they were written in the language of national minorities in compliance with the spelling of the language concerned. By amending Article 11 of this Law and by adding new Article 18a, the text of the law was also coordinated with the Law on Protection of Rights and Freedoms of National Minorities (the provisions of Articles 9 and 11), as well as with the Constitution of the Republic of Serbia (the provision of Article 79 paragraph 1). The new text of the provision of Article 11 paragraph 1 defines that in the territory of the unit of local self-government where the members of national minorities traditionally live, their language and script may be equally officially used, and it shall by all means be introduced by the unit of self-government by its statute, if the percentage of the members of the national minority concerned in the total number of population in its territory reaches $15 \%$ according to the results of the last census (paragraph 2). Paragraph 3 of this Article defines what the official use of some national minority language implies in particular (use of languages of national minorities in administrative and court proceedings and conduct of administrative and court proceedings in the language of national minorities; use of the language of national minorities in communications of the bodies having public powers with citizens; issuance of public documents and keeping official records and personal data basis in the languages of national minorities and acceptance of documents in those languages as valid documents; use of the languages of national minorities in election lists and election materials; use of the languages of national minorities in the activities of representation bodies, and paragraph 4 prescribes that in the units of local self-government where a minority language had been introduced into official use, this national minority language and script is also used to write, according to the tradition of the speaker of the language concerned, the names of bodies exercising public powers, names of the units of 
local self-government, names of dwelling areas, squares and streets and other topographic signs. Minority languages in official use in the activities of the bodies of the autonomous province are specified in its statute (paragraph 5), and laws and regulations are also published in minority languages, in accordance with special law (paragraph 6). Amendments and supplements to the Law on the Official Use of Language and Script in Article 11 paragraphs 7 and 8 define the right of members of national minorities whose number in the total population of the Republic of Serbia reaches at least $2 \%$ according to the latest census to refer to the republic bodies in their languages and the right to get a reply in the language concerned, namely the right of the members of national minorities whose number in the total population of the Republic of Serbia does not reach $2 \%$ to refer to the republic bodies in their languages and the right to get a reply in the language concerned through the unit of local self-government where the language of the national minority concerned is in official use, whereas the unit of local selfgovernment shall provide translations and bear the costs of translation of a letter addressed to the republic body and of the reply to it. By adding new Article 18a it is prescribed that the members of national minorities have the right to free choice and use of personal names and names of their children, as well as to entering these personal names in all public books, public records and personal data basis according to the minority language and spelling, which does not exclude that those names are also parallelly written according to Serbian language and spelling. The amendments and supplements of the Law on Official Use of Language and Script regulate that in the unit of local self-government where the national minority was in official use on the date of this law entering into force, the language concerned remains in official use, in accordance with the provision of Article 20 paragraph 2 of the Constitution of the Republic of Serbia, which establishes that the achieved level of human and minority rights may not be decreased.

19. The Decree on the Council of National Minorities of the Republic of Serbia, which was adopted by the Government in 2009, prescribes that Council shall preserve, improve and protect national, ethnic, religious, linguistic and cultural specific properties of the members of the national minorities in the Republic of Serbia. Its competences are: affirmation of national symbols and national minority holidays under the proposal of the councils of national minorities; consideration of bills and other regulations of significance for the fulfilment of national minority rights and the submission of its opinions to the Government; monitoring and consideration of achievements of the rights of the national minorities in the Republic of Serbia and the status of relations between the national minorities in the Republic of Serbia; proposals of measures for the promotion of the full and effective equality of the members of the national minorities and consideration of measures proposed for these purposes by other bodies and authorities; monitoring of achievement of co-operation of national councils with the competent authorities of the Republic of Serbia, autonomous provinces, municipalities, towns and the city of Belgrade; consideration of conditions for the activities of national councils; consideration of accomplishment of international obligations in 
respect of the achievement of the rights of the members of national minorities in the Republic of Serbia and accomplishment of international co-operation of the national councils; consideration of the list of candidates for the National Educational Council in accordance with Article 11 of the Law on Fundamentals of Educational System, and consideration of international or regional agreements related to the status of national minorities and protection of their rights in the process of conclusion of such agreements. The members of the Council are: the Prime Minister of the Government of the Republic of Serbia, who is also the President of the Council, the ministers of human and minority rights, state administration and local self-government, culture, education, youth and sports, religion, justice and internal affairs as the representatives of the Government, and the presidents of national councils of national minorities and the president of the Federation of Jewish Communities in Serbia whose position is equal to the position of the presidents of national councils. The Decree prescribes that that the National Council shall meet when necessary, however at least four times per year. The National Council enacts decisions by the majority of votes of all the representatives of the Government and the majority of votes of all presidents of national councils. At the request of the presidents of at least half of the presidents of national councils, the President of the National Council has a duty to call for a meeting not later than 30 days. Experts and administrative-technical support to the National Council is provided by the Ministry of Human and Minority Rights.

\subsubsection{The National Strategy for the Improvement of the Status of the Roma}

20. With the aim to improve the status of the Roma national minority, which is characterized as the most vulnerable minority group in the Republic of Serbia and its integration in public, economic, cultural and political life, in 2009 the Government of the Republic of Serbia adopted the Strategy for the Improvement of the Status of the Roma and the Action Plan for its implementation with the projection of budgetary funds for the implementation of planned measures and activities for the period 2009-2011. Beside this aim, the Strategy gives the basis for identification and implementation of affirmative action, primarily in the field of education, health, employment and housing. The Acton Plan, which presents operationalisation of the priorities and recommendations of the Strategy, includes 13 fields in total: in addition to action plans in four priority fields (the Roma Decade, employment, housing, education and health, adopted in 2005, which had been revised, the Action Plan also prescribes measures and activities in the field of social care, internally displaced persons, returnees pursuant to the readmission agreements and it also covers the field of improvement of the status of women, than the field of media, culture and information in mother tongue as well as in the fields of discriminations and political participation

\subsubsection{Judicial reform}

21. Since the establishment of the Government of the Republic of Serbia in 2008, the Ministry of Justice started root reforms with the aim to recover the obsolete and 
non-functional judicial system. In this respect, a large number of researches and analyses on the conditions and problems of the judiciary sector has been carried out. The necessity to carry out the reform is caused by the fact that the judicial system did not function in accordance with the European standards and the needs of the citizens of the Republic of Serbia in a longer period of time, in spite of numerous legal amendments made since 2000. The necessity to carry out the reform is also caused by numerous complaints by citizens related to the proceedings not conducted within reasonable time, impossibility of execution of judgements, as well as to corruption. Some of the failures found are: excessively complex and wide system of courts, unclear election standards, discharge from duty, results of activities and progress of judges, lack of capacities for integrated budget planning and definition and measuring of the system results, obsolete models of functioning of judiciary administration, as well as the lack of continuing training of judges and other holders of judiciary positions. The reform of the judiciary has the aim to provide fair and just trials, facilitate access to justice, proceedings in the language of the party in the place of residence, responsibility of judges for unprofessional and unconscious work, closure of proceedings within reasonable time, as well as efficient execution of final court decisions. The members of national minorities are enabled to have an easier access to justice and to accomplish their rights before courts in accordance with the European standards. In December 2008, the National Assembly of the Republic of Serbia adopted a package of laws on judiciary, which included the following laws: the Law on High Judicial Council, the Law on the State Council of Prosecutors, the Law on Judges, the Law on Public Prosecutor's Office, the Law on Organization of Courts, the Law on Seats and Territorial Jurisdiction of Courts and Public Prosecutor's Offices, the Law on Amendments and Supplements to the Law on Torts. The judicial laws organize the judicial network in an entirely new way, including new institutions to guarantee independence and numerous mechanisms that should enable higher efficiency and better functioning of the system. These laws establish the High Judicial Council and the State Council of Prosecutors as new institutions of judiciary and a new network of judicial institutions that should considerably contribute to the improvement of efficiency and decrease the workload of the existing network of courts. The new laws also prescribe the establishment of an independent judiciary budget, as well as the elaboration of clear and measurable criteria for the election, progress, disciplinary procedure and discharge from duty of judges and prosecutors, to be managed by the High Judicial Council and the State Council of Prosecutors on the occasion of assessment of the work of judges and prosecutors.

22. The new legal solutions have also amended the competence and the organization of courts. Article 11 of the Law on Organization of Courts establishes that judicial power in the Republic of Serbia belongs to courts of general and special jurisdiction. The courts of general jurisdiction are magistrate courts, high courts, appellate courts and the High Court of Cassation, whereas the courts of special jurisdiction are commercial courts, the Commercial Appellate Court, misdemeanour courts, the High Misdemeanour Court and the Administrative 
Court. The introduced appellate courts adopt decisions on appeals against the decisions of the magistrate and the high courts. The High Court of Cassation is the highest court in the Republic of Serbia.

23. The Law on Seats and Regions of Courts and Public Prosecution Offices has been in force since 1 January 2010, which establishes, inter alia, magistrate and high courts, defines their seats and regions where they have jurisdiction and specify the departments of the Administrative Court and the regions where they exercise jurisdiction ${ }^{1}$. The new organization of the judicial network enables the citizens of the Republic of Serbia to have access to justice in the same places where they had accomplished this right before, and it should also considerably contribute to more efficient, impartial and objective trials. The 138 existing municipal courts have been reorganized into 34 magistrate courts, of which each one has court units. Specialization within the framework of municipal courts has also been foreseen to contribute to considerably higher efficiency and quality of judgements. Article 3 of this Law prescribes the following magistrate courts: 1) The First Magistrate Court in Belgrade, for the territory of the municipalities of Vrčar, Voždovac, Zvezdara, Zemun, Novi Beograd, Palilula, Rakovica, Savksi venac, Stari grad and Čukarica; 2) The Second Magistrate Court in Belgrade for the territory of the municipalities of Barajevo, Grocka, Lazarevac, Mladenovac, Obrenovac, Sopot and Surčin, with court units in Lazarevac, Mladenovac, Obrenovac and Sopot; 3) The Magistrate Court in Bor, for the territory of the municipality of Bor; 4) The Magistrate Court in Valjevo, for the territory of the municipalities of Lajkovac, Ljig, Mionica, Osečina and Ub and for the town of Valjevo, with court units in Lajkovac, Ljig, Mionica, Osečina and Ub; 5) The Magistrate Court in Vranje, for the territory of the municipalities of Bosilegrad, Bujanovac, Vladičin Han, Preševo, Surdulica and Trgovište and for the town of Vranje, with the court units in Bosilegrad, Bujanovac, Vladičin Han, Preševo and Surdulica; 6) The Magistrate Court in Vršac, for the territory of the municipalities of Bela Crkva, Vršac and Plandište, with the court units in Bela Crkva and Plandište; 7) The Magistrate Court in Zaječar, for the territory of the municipalities of Boljevac, Knjaževac and Sokobanja and for the town of Zaječar, with the court units in Boljevac, Knjaževac and Sokobanja; 8) The Magistrate Court in Zrenjanin, for the territory of the municipalities Žitište, Novi Bečej and Sečanj and for the town of Zrenjanin, with the court units in Novi Bečej and Sečanj; 9) The Magistrate Court in Jagodina, for the territory of the municipalities of Rekovac and Svilajnac and for the town of Jagodina, with the court units in Rekovac and Svilajnac; 10) The Magistrate Court in Kikinda, for the territory of the municipalities of Kikinda, Nova Crnja, Novi Kneževac and Čoka, with the court units in Nova Crnja and Novi Kneževac, 11) The Magistrate Court in Kosovska Mitrovica, for the territory of the Autonomous Province Kosovo and Metohija, with the court units in Goraždevac, Gračanica, Ranilug and Štrpac; 12) The Magistrate Court in Крагујевцу, for the territory of the municipalities of Aranđelovac, Batočina, Knić, Lapovo, Rača and Topola and for the town of Kragujevac, with the court

\footnotetext{
1 The newly organized judicial network shows only the types of courts of relevance for the implementation of the Charter.
} 
units in Aranđelovac, Batočina, Rača and Topola; 13) The Magistrate Court in Kraljevo, for the territory of the municipalities of Vrnjačka Banja and Raška and for the town of Kraljevo, with the court units in Vrnjačka Banja and Raška; 14) The Magistrate Court in Kruševac, for the territory of the municipalities of Aleksandrovac, Brus, Varvarin, Ćićevac and Trstenik and for the town of Kruševac, with court units in Aleksandrovac, Brus, Varvarin and Trstenik; 15) The Magistrate Court in Leskovac, for the territory of the municipalities of Bojnik, Vlasotince, Lebane, Medveđa and Crna Trava and for the town of Leskovac, with court units in Vlasotince and Lebane; 16) The Magistrate Court in Loznica, for the territory of the municipalities of Krupanj, Ljubovija and Mali Zvornik and for the town of Loznica, with court units in Krupanj and Ljubovija; 17) The Magistrate Court in Negotin, for the territory of the municipalities of Kladovo, Majdanpek and Negotin, with court units in Kladovo and Majdanpek; 18) The Magistrate Court in Niš, for the territory of the municipalities of Aleksinac, Gadžin Han, Doljevac, Ražanj and Svrljig and for the town of Niš, with court units in Aleksinac, Ražanj and Svrljig; 19) The Magistrate Court in Novi Pazar, for the territory of the municipalities of Sjenica and Tutin and for the town of Novi Pazar, with court units in Sjenica and Tutin; 20) The Magistrate Court in Novi Sad, for the territory of the municipalities of Bač, Bačka Palanka, Bački Petrovac, Beočin, Bečej, Vrbas, Žabalj, Srbobran, Sremski Karlovci, Temerin and Titel and for the town of Novi Sad, with court units in Bač, Bačka Palanka, Bački Petrovac, Beočin, Bečej, Vrbas, Žabalj, Srbobran, Temerin and Titel; 21) The Magistrate Court in Pančevo, for the territory of the municipalities of Alibunar, Kovačica, Kovin and Opovo and for the town of Pančevo, with court units in Alibunar, Kovačica and Kovin; 22) The Magistrate Court in Paraćin, for the territory of the municipalities of Despotovac, Paracin and Cuprija, with court units in Despotovac and Ćuprija; 23) The Magistrate Court in Pirot, for the territory of the municipalities of Babušnica, Bela Palanka, Dimitrovgrad and Pirot, with court units in Babušnica, Bela Palanka and Dimitrovgrad; 24) The Magistrate Court in Požarevac, for the territory of the municipalities of Veliko Gradište, Golubac, Žabari, Žagubica, Kučevo, Malo Crniće and Petrovac na Mlavi and for the town of Požarevac, with court units in Veliko Gradište, Žabari, Žagubica, Kučevo and Petrovac na Mlavi; 25) The Magistrate Court in Požega, for the territory of the municipalities of Arilje, Ivanjica Kosjerić and Požega, with court units in Arilje, Ivanjica and Kosjerić; 26) The Magistrate Court in Prijepolje, for the territory of the municipalities of Nova Varoš, Priboj and Prijepolje, with court units in Nova Varoš and Priboj; 27) The Magistrate Court in Prokuplje, for the territory of the municipalities of Blace, Žitorađa, Kuršumlija, Merošina and Prokuplje, with court units in Blace and Kuršumlija; 28) The Magistrate Court in Smederevo, for the territory of the municipalities of Velika Plana and Smederevska Palanka and for the town of Smederevo, with court units in Velika Plana and Smederevska Palanka; 29) The Magistrate Court in Sombor, for the territory of the municipalities of Apatin, Kula and Odžaci and for the town of Sombor, with court units in Apatin, Kula and Odžaci; 30) The Magistrate Court in Sremska Mitrovica, for the territory of the municipalities of Inđija, Irig, Pećinci, Ruma, Stara Pazova and Šid and for the town of Sremska Mitrovica, with 
court units in Inđija, Irig, Pećinci, Ruma, Stra Pazova and Šid; 31) The Magistrate Court in Subotica, for the territory of the municipalities of Ada, Bačka Topola, Kanjiža, Mali Iđoš and Senta and for the town of Subotica, with court units in Ada, Bačka Topola, Kanjiža and Senta; 32) The Magistrate Court in Užice, for the territory of the municipalities of Bajina Bašta and Čajetina and for the town of Užice, with court units in Bajina Bašta and Čajetina; 33) The Magistrate Court in Čačak, for the territory of the municipalities of Gornji Milanovac and Lučani and for the town of Čačak, with court units in Gornji Milanovac and Guča; 34) The Magistrate Court in Šabac, for the territory of the municipalities of Bogatić, Vladimirci and Koceljeva and for the town of Šabac, with court units in Bogatić, Vladimirci and Koceljeva. Article 4 of the Law prescribes that high courts are: 1) the High Court in Belgrade, for the territory of the First and the Second Magistrate Courts in Belgrade; 2) the High Court in Valjevo, for the territory of the Magistrate Court in Valjevo; 3) the High Court in Vranje, for the territory of the magistrate Court in Vranje; 4) the High Court in Zaječar, for the territory of the Magistrate Court in Bor and for the territory of the Magistrate Court in Zaječar; 5) the High Court in Zrenjanin, for the territory of the Magistrate Court in Zrenjanin and for the territory of the Magistrate Court in Kikinda; 6) the High Court in Jagodina, for the territory of the Magistrate Court in Jagodina and for the territory of the Magistrate Court in Paraciin; 7) the High Court in Kosovska Mitrovica, for the territory of the Magistrate Court in Kosovska Mitrovica; 8) the High Court in Kragujevac, for the territory of the Magistrate Court in Kragujevac; 9) the High Court in Kraljevo, for the territory of the Magistrate Court in Kraljevo; 10) the High Court in Kruševac, for the territory of the Magistrate Court in Kruševac; 11) the High Court in Leskovac, for the territory of the Magistrate Court in Leskovac; 12) the High Court in Negotin, for the territory of the Magistrate Court in Negotin; 13) the High Court in Niš, for the territory of the Magistrate Court in Niš; 14) the High Court in Novi Pazar, for the territory of the Magistrate Court in Novi Pazar; 15) the High Court in Novi Sad, for the territory of the Magistrate Court in Novi Sad; 16) the High Court in Pančevo, for the territory of the Magistrate Court in Vršac and for the territory of the Magistrate Court in Pančevo; 17) the High Court in Pirot, for the territory of the Magistrate Court in Pirot; 18) the High Court in Požarevac, for the territory of the Magistrate Court in Požarevac; 19) the High Court in Prokuplje, for the territory of the Magistrate Court in Prokuplje; 20) the High Court in Smederevo, for the territory of the Magistrate Court in Smederevo; 21) the High Court in Sombor, for the territory of the Magistrate Court in Sombor; 22) the High Court in Sremska Mitrovica, for the territory of the Magistrate Court in Sremska Mitrovica; 23) the High Court in Subotica, for the territory of the Magistrate Court in Subotica; 24) the High Court in Užice, for the territory of the Magistrate Court in Požega, the Magistrate Court in Prijepolje and the Magistrate Court in Užice; 25) the High Court in Čačak, for the territory of the Magistrate Court in Čačak; 26) the High Court in Šabac, for the territory of the Magistrate Court in Loznica and for the territory of the Magistrate Court in Sabac. Article 8 of this Law prescribes the following departments of the Administrative Court, which has been established for the territory of the Republic of Serbia, with the seat in Belgrade: 1) 
Department in Kragujevac, for the territories of the high courts in Jagodina, Kragujevac, Kruševac, Kraljevo, Novi Pazar, Užice and Čačak; 2) Department in Niš, for the territory of the high courts in Vranje, Kosovska Mitrovica, Leskovac, Niš, Prokuplje and Pirot; 3) Department in Novi Sad, for the territory of the high courts in Zrenjanin, Novi Sad, Pančevo, Sombor, Sremska Mitrovica and Subotica.

24. Minority languages have been in official use at the following magistrate courts:

\begin{tabular}{|l|l|}
\hline The Magistrate Courts & Minority languages in official use \\
\hline Magistrate Court in Vranje & Albanian; Bulgarian \\
\hline Magistrate Court in Vrsac & Hungarian, Romanian, Slovak and Czech \\
\hline Magistrate Court in Zrenjanin & Hungarian, Romanian, Slovak \\
\hline Magistrate Court in Kikinda & Hungarian \\
\hline Magistrate Court in Leskovac & Albanian \\
\hline Magistrate Court in Novi Pazar & Bosniak \\
\hline Magistrate Court in Novi Sad & Hungarian, Ruthenian, Slovak \\
\hline Magistrate Court in Pancevo & Hungarian, Romanian, Slovak \\
\hline Magistrate Court in Pirot & Bulgarian \\
\hline Magistrate Court in Prijepolje & Bosniak \\
\hline Magistrate Court in Sombor & Hungarian, Ruthenian, Slovak \\
\hline Magistrate Court in Sremska Mitrovica & Ruthenian, Slovak \\
\hline Magistrate Court in Subotica & Hungarian, Croatian \\
\hline
\end{tabular}

Minority languages have been in official use at the following high courts:

\begin{tabular}{|l|l|}
\hline The High Courts & Minority languages in official use \\
\hline High Court in Vranje & Albanian; Bulgarian \\
\hline High Court in Zrenjanin & Hungarian, Romanian, Slovak \\
\hline High Court in Leskovac & Albanian \\
\hline High Court in Novi Pazar & Bosniak \\
\hline High Court in Novi Sad & Hungarian, Ruthenian, Slovak \\
\hline High Court in Pancevo & Hungarian, Romanian, Slovak and Czech \\
\hline High Court in Pirot & Bulgarian \\
\hline High Court in Sombor & Hungarian, Ruthenian, Slovak \\
\hline High Court in Sremska Mitrovica & Ruthenian, Slovak \\
\hline High Court in Subotica & Hungarian, Croatian \\
\hline High Court in Užice & Bosniak \\
\hline
\end{tabular}

25. Minority languages have been in official use at the following departments of the Administrative Court:

\begin{tabular}{|l|l|}
\hline Administrative court units & Minority languages in official use \\
\hline Units in Kragujevac & Bosniak \\
\hline Units in Niš & Albanian; Bulgarian \\
\hline Units in Novi Sad & $\begin{array}{l}\text { Hungarian, Romanian, Ruthenian, Slovak, } \\
\text { Croatian and Czech }\end{array}$ \\
\hline
\end{tabular}


26. The set of judicial laws prescribes novelties related to election of judges and prosecutors being the members of national minorities. For example, in Article 46 the Law on Judges prescribes that on the occasion of election and proposals for election of judges discrimination on any grounds is prohibited, that care should be taken of the national composition of population, adequate representation of the members of national minorities and of the knowledge of professional legal terminology in minority languages, which is in official use at court. The election procedure has entirely been transferred to the new body, the High Judicial Council, which had adopted the Rules on the Criteria and Norms for Assessment of Qualifications, Skills and Adequacy of Judges. The Law on Public Prosecution Offices prescribes in Article 182, which relates to the proposal and election of candidates for the position of public prosecutors, that the new body, the State Council of Prosecutors, on the occasion of proposals and election, shall take into account qualifications, skills and adequacy of candidates, according to the criteria and norms for the assessment of qualifications, skills and adequacy prescribed by this body in accordance with the law. On the occasion of election and proposal of candidates for the position of public prosecutor, any discrimination on any grounds is prohibited, and care shall be taken of the national composition of population, adequate representation of the members of national minorities and knowledge of professional legal terminology in the minority language in official use at court. The similar rule also applies to prosecution apprentices. Namely, Article 122 of the Law on Public Prosecution Offices prescribes that on the occasion of employment of prosecution apprentices special care shall be taken of the national composition of population, adequate representation of the members of national minorities and knowledge of professional legal terminology in the minority language in official use at court.

\subsubsection{Establishment of the Ministry of Human and Minority Rights}

27. The establishment of the Government of Republic of Serbia in July 2008 also included the establishment of the Ministry for Human and Minority. Article 26 of the Law on Ministries prescribes that the Ministry for Human and Minority Rights shall perform the jobs of state administration related to: the general issues of the status of the members of the national minorities, keeping the registry of the national councils of the national minorities, election of the national councils of the national minorities, protection and promotion of human and minority rights, preparation of regulations on human and minority rights, monitoring of harmonization of the national regulations with the international treaties and other international legal documents on human and minority rights, representation of the Republic of Serbia before the European Court of Human Rights, the status of the members of the national minorities living in the territory of the Republic of Serbia and accomplishment of minority rights, accomplishment of contacts of the national minorities with their native countries, policy against discrimination, the status and accomplishment of competence of the national councils of the national minorities, co-ordination of activities of the state administration bodies in the 
areas of protection of human rights and other activities prescribed by law. The establishment of the Ministry of Human and Minority Rights, which also includes the Sector for Improvement and Protection of Rights of National Minorities, the institutional bases for a comprehensive and entire approach in protection, affirmation and improvement of minority rights in the Republic of Serbia in accordance with the Constitution, positive regulations and the ratified international treaties in this field.

\subsection{Novelties expected during the next monitoring cycle of the implementation of the Charter}

\subsubsection{The Census}

28. The last population census in the Republic of Serbia was conducted in 2002, and the new population census shall be conducted in 2011. The Law on Census of Population, Households and Flats prescribes that the census shall include the following: citizens of the Republic of Serbia, foreign citizens and stateless persons who have residence in the Republic of Serbia, whether at the time of the census they shall be in the Republic of Serbia or abroad, households of the mentioned persons and flats and other dwelling premises. The census shall also include the citizens of the Republic of Serbia, foreign citizens and stateless persons who have residence abroad who shall be living in the Republic of Serbia at the time of the census for at least one year. The following data shall be collected about the persons to be covered by the census: name and surname, sex, date of birth and personal identification number of citizens, place of birth, place of residence of the mother at the time of the person's birth, dwelling area from which the person had moved in and the year of moving in, state from which the person moved in, year of moving in and the main reason of moving in, marital status, number of live-born children and years of their birth, citizenship, national affiliation, mother tongue, religion, literacy, education, title, school attendance, activity, profession, employment status, activity, sources of income, capacity of supporting person, place of work, namely, place of school attendance and frequency of return to place of permanent residence, functional capacity of persons to perform everyday actions, relation with the person the household is registered with and the reason of absence, namely, presence in the place of census. The Law on Census prescribes the role and the jobs of the Republic Statistical Institute, census commissions and units of local self-government in the performance of census, the jobs of ministries and special organizations, as well as the role of the Republic Geodetic Institute. Also, this Law prescribes the obligations and duties of the person providing such data and of the persons performing jobs related to the census. The census officials, instructors, controllers and other persons performing jobs related to the census are obliged to take strict care of the precision of entered data, namely, of the precise data processing provided by the persons giving such data. Since this Law prescribes the protection of the collected data, persons performing jobs related to the census are obliged to keep the data collected from the persons subject to the census as confidential, 
whereas the data collected in the census shall be explicitly used for statistical purposes. Any person included in the census is obliged to provide the data required from him/her in the census and to provide exact and complete replies in the census forms. The data about the absent members of households shall be provided by the person who knows such data best, and for children younger than fifteen years, such data shall be provided by parent, adopter parent or custodian.

29. Within the framework of ethnic properties of the population, the census shall collect the data about national affiliation, religion and mother tongue (mother tongue means the language the person learned in the earliest childhood, namely, the language the person concerned finds to be his/her mother tongue, if several languages are spoken within the household; for dumb and deaf persons, it is prescribed to enter the language mainly spoken at their home as a reply to this question). It has been foreseen that the question concerning national affiliation and mother tongue shall be designed as an open reply (Article 27 of this Law). The methodological instructions specify that the person performing the census is obliged to enter the exact reply of the person being asked to the question concerning ethnic properties. In case some person shall not wish to declare himself/herself about national affiliation, the person performing the census shall write as a reply to this question: „Not declare“. The very Census Form contains legal remedy that pursuant to Article 47 of the Constitution of the Republic of Serbia a citizen is not obliged to declare himself/herself about his/her national affiliation. The Law on the Census (Article 30) prescribes penalty provisions in case the persons performing the jobs related to the census, contrary to the will of the person included in the census, require that such a person declares himself/herself about his/her national affiliation or religion. The basic census forms shall be printed in Serbian in Cyrillic script. To enter the replies, the persons performing the census may use both Cyrillic and Latin scripts. The basic census forms shall be translated into the language of 6 mostly represented national minorities (according to the results of the 2002 Census), as well as in English. The persons performing the census shall use these forms only as samples. In view of extraordinary delicacy of the questions concerning ethnic characteristics of the population, the methodological instructions strictly prescribe that in case the person performing the census makes an error when entering the replies to these questions, even if a letter is wrong, no corrections are permitted. In such cases, the person performing the census is obliged to fill in a new Census Form, whereas the Census containing an error must be cancelled and returned to the instructor. The instructor shall keep records of each person performing the census within his/her competence (in average from 8 to 10 persons performing the census) concerning the total number of forms he/she had received, the number of filled in forms, the number of returned forms having an error and the number of returned -empty forms.

30. Intensive methodological-organizational preparations for the forthcoming census have been in progress at the Republic Institute of Statistics, which relate to: preparation of final content of basic census forms (Questionnaire or Question List 
and Questionnaire for Households and Flats), preparation of methodological instructions, definitions of programme how to make tables of census results, preparation of media campaign, co-operation with ministries, which have, according to the Law on Census, obligations in preparation and implementation of the census of specific categories of persons, such as listing of persons assigned to diplomatic-consular and other representative institutions of the Republic of Serbia and who work with commercial companies abroad, listing of military and civil persons living at the time of the census at military camps, military schools and similar military institutions, etc. Preparation of classification of national affiliation, mother tongue and religion has been in progress. Before the adoption of the final decision on modalities of these categories, the classification shall be forwarded to the competent institutions for verification (the Ministry of Human and Minority Rights, the Ministry of Religions, the Ombudsman, etc.).

31. The new population census shall also provide the statistical data on ethnic characteristics, which are the base for the continuation of the policy of affirmation, as well as undertaking of measures for further promotion of minority rights in the Republic of Serbia, including the right to use minority languages, too.

\subsubsection{Election of the national councils of the national minorities}

32. The elections of the members of all national councils were held simultaneously on 6 June 2010. Bearing in mind the assessments and opinions of the Committee of Experts, stated in its first report, that the national councils of national minorities present a particularly suitable method of taking into accounts the needs and wishes of the groups using regional or minority languages, and that additional efforts must be made in order that the speakers of the Albanian and Czech languages also have representatives in the form of such bodies, the Ministry of Human and Minority Rights had held meetings with the representatives of the interested national minorities, especially with the representatives of the Albanian national minority, at which the Law and the obligations to be fulfilled by them were presented in order to be able to establish their national councils. During the elections for the national councils of the national minorities, 436,334 members of 16 national minorities (Albanian, Ashkali, Bosnian, Bunjevac, Bulgarian, Vlach, Greek, Egyptian, Hungarian, German, Romani, Romanian, Ruthenian, Slovak, Ukrainian and Czech national minorities) registered in the special election list before 21 May 2010, when the election list was closed, had opportunities to vote directly for the members of the national councils of the national minorities. Direct elections were carried out at 858 polling stations. Three national minorities (Macedonian, Slovak and Croatian) elected their national councils the same day through the electronic assembly. The entire election material was available in bilingual forms, Serbian and minority language and script in the official use in the unit of local self-government where the election took place.

33. By the election of their national councils, national minorities get legitimate representatives for protection, maintenance, fostering and improvement of the 
rights to their identity and their own language and script, as guaranteed by the Constitution and the national regulations, as well as the international treaties on human and minority rights signed by the Republic of Serbia. Since the national councils of national minorities are also advisory bodies to the state authorities, by the election of minority representatives as their members, the state gets the partners in creation and implementation of minority policy the final strategic goal is the integration of national minorities into all spheres of social life of the Republic of Serbia.

34. In the Section 2.12. of the First Periodic Report on the implementation of the Charter it is explained that the national councils of national minorities are a form of cultural autonomy of national minorities and functional decentralization introduced into the legal system in 2002, by the adoption of the Law on Protection of Rights and Freedoms of National Minorities. The elaboration of this Law on the issues of competences and procedure of election of national councils of national minorities, through which the members of national minorities accomplish the right to self-government in the field of official use of language and script, education, information and culture, is the Law on the National Councils of the National Minorities. Article 10 of this Law prescribes general competences of national councils. National councils adopt and amend their statutes, financial plans and statements, they dispose of their own property, decide on the names, symbols and seals of national councils, establish national symbols, signs and holidays of national minorities, establish institutions, associations, foundations and commercial companies in the field of culture, education, information and official use of language and script, propose representatives of national minorities in the council of ethnic relations in the units of local self-government and establish and grant recognitions. The power of national councils to initiate adoption of laws and other regulations in the field of education, culture, information and official use of language and script is of particular importance, as well as the power to monitor their implementation in practice. In addition to the above mentioned powers, national councils also have the right to initiate before the Constitutional Court, the Ombudsman, the provincial and local ombudsmen, under certain conditions, the procedure of decision making on protection of individual and collective rights of national minorities.

35. The competences of the national councils in the field of education are prescribed in the provisions of Articles 12-15 of the Law. The national councils may, in accordance with the law, establish institutions for education and up-bringing, accommodation of pupils and students and exercise the rights of founders. The Republic, the Autonomous Province and the units of local self-government may either entirely or partially transfer the founders' rights in respect of these institutions to the national councils. The national councils have special powers at the educational institutions where the teaching is also carried out in minority languages or where speech, language or culture of national minority is studied as a special subject. The national council shall propose to the National Educational Council general guidelines of pre-school programmes, curricula and the 
programmes of primary and secondary education and up-bringing, the programme of primary and secondary education and up-bringing for minority languages and shall give the opinion to the National Educational Council on the curricula for Serbian language as a non-mother tongue. The National Educational Council may, only under the previous approval of the national council, propose to the ministry in charge of educational affairs to approve the use of textbooks and teaching aids the contents of which express specific properties of the national minorities concerned. The Minister shall approve the use of domestic or imported textbooks in the language of national minority under the proposal of the national council. The national councils also have other powers in the field of education.

36. In the field of culture (Article 16-18 of the Law), the competences of the national councils are defined in a similar way as the competences in the field of education. The national councils shall establish cultural institutions to preserve cultural specific properties and national identity of national minorities and shall exercise the rights and obligations of founders. The Republic, the Autonomous Province and the units of local self-government may either entirely or partially transfer the founders' rights to the national councils. The national councils have the power to appoint a member of the board of directors of the institution concerned, give opinions on the proposed members of the board of directors and give opinion in the procedure of appointment of the director of the institution that the national council had established to be of special importance for preservation of identity of national minority. The national councils shall establish the strategy of cultural development of national minority, define which institutions and manifestations in the field of culture are of special importance for preservation, promotion and development of specific properties and national identity of a certain national minority, propose at least one candidate for the joint list of candidates for the election of the National Council for Culture and also have other competences in the field of culture.

37. In the field of information (Article 19-21 of the Law), the national councils may either independently or together with other legal entities establish the institutions and commercial companies to perform newspaper-publishing and radio-television activities, printing and reproducing of media programmes and exercise the rights and duties of founders. The founder's rights in the public companies and institutions in the field of public information, which had been established by the Republic, the Autonomous Province or the unit of local self-government may be transferred to the national councils. The Law prescribes that the national councils shall participate in the management of the relevant institutions, give opinions in the procedure of appointment of the members of the board of directors, the programme board and the managing director of the Radio-Broadcasting Agency of Serbia, give opinions in the procedure of appointment of the members of the board of directors, the programme board and the managing director of the RadioBroadcasting Agency of Vojvodina, establish the criteria for the election of the editor in charge of the programme in minority language at the public service institution, etc. The national council shall adopt the strategy of information 
development in minority language and give proposals to the Republic RadioBroadcasting Agency on the occasion of preparation of the strategy of radiobroadcasting development.

38. In respect of the competences in the field of the official use of language and script, (Article 22 of the Law), the national councils shall establish the traditional names of the units of local self-government, settlements and other geographic names in minority languages if some minority language is in the official use in such areas, propose to the competent authority to display the names of the units of local self-government, settlements and other geographic names in minority languages, propose to establish minority language and script as the official language and script in the unit of local self-government, propose to amend the names of streets, squares and other parts of settlements that had been established to be of special importance for the national minority concerned, propose to the competent authority to supervise the official use of minority language and script, etc..

\subsection{Implementation of the recommendations of the Committee of Ministers of the Council of Europe (RecChL(2009)2)}

39. On the occasion of assessment of the First Period Report on the implementation of the Charter, the Committee of Ministers of the Council of Europe recommended to the authorities of the Republic of Serbia to take into account all observations of the Committee and stressed the following recommendations as priorities:

Recommendation 1: promote awareness and tolerance in Serbian society at large vis-à-vis the regional or minority languages and the cultures they represent.

40. Chapters 3.3.4, 4.4. and 4.5. of this Report contain detailed information on awareness and tolerance raising activities in the Serbian society concerning regional or minority languages and the cultures they represent.

Recommendation 2: clarify the status of Bunjevac and Vlach in consultation with representatives of all speakers.

41. In the Section 3.3.2. of the First Periodic Report on the implementation of the Charter, the languages in the Republic of Serbia the Charter is applied to are precisely stated, not including the Bunjevac language, explaining that the language concerned has not been standardized yet. It is stressed in the mentioned Report that the State does not deny the possibility that the Bunjevac language shall be treated as minority language as long as standardization is not a condition for the application of certain measures. In view of the efforts being made by the National Council of the Bunjevac National Minority in order to have the Bunjevac language standardized, as well as in view of the measures undertaken by the State with the aim to preserve it, which had been assessed in the first report by the Committee of Experts to be relevant for the application of the Charter to the 
Bunjevac language and in which it had expressed its appraisal for such activities of the State, after having consultations with the Bunjevac speakers, it was decided that in the Second Report Part II of the Charter would be applied to the Bunjevac language. A detailed report on the Bunjevac language is contained in Section 3.2.1. of the Report.

42. In the same Section (3.3.2) of the First Periodic Report on the implementation of the Charter, the Vlach language is also stated as the language the Charter is applied to, and in Section 4.2. this language is mentioned as the language for which no obligations contained in Part III of the Charter were taken over. The Republic of Serbia applies Part II of the Charter to the Vlach language, treating it as a special language, which is considered to be their mother tongue by 54,818 persons (according to the 2002 Population census). The National Council of the Vlach National Minority, as the institution in charge of cultural autonomy, regulated by the Statute that the Romanian literature language was the mother tongue of the Vlachs and requested that it was introduced into the official use and into the educational system in the territories where the Vlachs traditionally lived in the East of Serbia. In essence, such a request reflects the debates present in the Republic of Serbia lately concerning the national identity of the Vlach, the relation between the Romanian and the Vlach national minorities and the accomplishment of the rights of the Vlach national minority in the Republic of Serbia. In their activities up to now the competent state authorities have not been included in the debates on the national affiliation of the Vlach, having the standpoint that the authorities in the Republic of Serbia may not and must not interfere into the debates on national identity, that they must not arbitrate in disputes on national identity of certain national communities, nor impose national identity to any national community. Any support to the activities in this context would mean imposition of national identity to certain communities, which is contrary to the Constitution and the positive legal regulations in the Republic of Serbia, and also contrary to the international treaties signed by the State. It is also stressed this time that the authorities of the Republic of Serbia had explicitly decided not to take part in the debates on ethnic affiliation of any national minorities, including the Vlach and the Romanian national minority. Proceeding from the constitutional solutions (Article 47) and the Law on Protection of Rights and Freedoms of National Minorities (Article 5), the State also applies in practice the basic principle of freedom of national affiliation and expression and treats the Vlach and the Romanian minorities as equal and separate identities. The fact that the National Council of the Vlach national minority established the Romanian language to be the mother tongue of the Vlach national minority thus ignoring, during the 2002 census, freely expressed will of persons related to their national identity and the language they speak, is of no importance for the State. Namely, according to the Constitution and the laws of the Republic of Serbia, the national councils have no competences to establish or proclaim what language the members of the national minority they represent speak. The policy of the State towards national minorities is explicitly based on self-identification and selfdetermination of persons belonging to national minorities, namely on the 
individual right. All activities of the national councils, as legitimate representatives of the communities and the holders of cultural rights, which do not comply with them, in the opinion of the State, are not only contrary to the provisions of the Constitution, the national laws and the international treaties, but they would also present elusion of the right through disclaiming individual rights based on the alleged accomplishment of collective rights. Moreover, once elected, the national councils have the duty to exercise their competences, namely to participate in the decision making process or adopt decisions on their own, in fact to protect the identity of their minority. To conclude, neither the National Council of the Vlach national minority, as long as there are persons who do not declare themselves to be the Vlachs during the census and as long as there is expressed care of such persons to preserve their common identity, not only through the National Council, but also through other forms of organization and activities, could disclaim the Vlach specific properties or the Vlach language. In this context, it is important to mention that by the recognition of the right to form two separate national councils, the Vlach and the Romanian, the State also accepted all those specific properties implying identity of national minority, including also, in this case, based on the will expressed in the census, the language they speak. In consultations for the purpose of clarification of the status of the Vlach language according to the Charter, the representatives of the National Council of the Vlach national minority regained their opinions that the Romanian language is the language of the Vlach national minority and that it should be introduced into the official use and into the educational system in the Republic of Serbia, in spite of the fact they said themselves that the Romanian language is not spoken, read and written by over $98 \%$ of the Vlachs. Proceedings from the above mentioned and in view of the fact that a certain group of citizens in the territory of the Republic of Serbia use the Vlach language, in the opinion of the State, make this language a minority language as defined within the framework of the Charter, and accordingly, Part II of the Charter is applied to the Vlach language. A detailed report on the Vlach language is contained in the Section 3.2.2. of this Report.

Recommendation 3: introduce teaching of/in Part II languages at primary and secondary levels.

43. The information on the activities for the provision of teaching of languages from Part II at primary and secondary schools are contained in chapter 3.3.3. of this Report.

Recommendation 4: strengthen teacher training and provide adequate teaching materials for all regional or minority languages.

44. The information on the activities for the improvement of training of teachers and provision of adequate teaching materials for all regional and minority languages contained 4.1.8. of this Report.

Recommendation 5: secure the implementation of Articles 9 and 10, in particular regarding Romani and Ukrainian, and ensure that the Part III languages can be 
used in relations with local branches of the State authorities.

45. The legal regulations of the Republic of Serbia ensure in full the implementation of selected paragraphs and sub-paragraphs of Article 9 of the Charter. As stated in the Section 4.2. of the Report, in the proceedings before the courts of the Republic of Serbia, all participants have the right to use their language through interpreters and learn the facts in their language, which primarily relates to the speakers of minority languages, but to the speakers of other languages as well. The right of speakers of minority languages to use their minority languages through court-tosworn translators and interpreters, if the proceedings are not held in their language, is strictly complied with, and the costs of translations and interpretations are on the account of courts. The problem of use of Romani and Ukrainian languages in the proceedings before the courts has been noticed in practice. With the aim to ensure and accomplish the rights of the members of all national minorities to use their languages in the proceedings before the courts, measures have been undertaken in order to increase the number of sworn-to-court interpreters for the Romani and the Ukrainian languages and to increase the number of lay-judges who are the members of the Romani and the Ukrainian nationalities, namely, the speakers of those languages. In this sense, in 2007 the Ministry of Justice issued advertisements for sworn-to-court interpreters with permanent commission on the grounds of previously established needs of municipal and district courts in the Central Serbia and for the sworn-to-court interpreters for the Ukrainian language in the territory of AP of Vojvodina. On the grounds of this advertisement, two sworn-to-court interpreters for the Romani language for the courts in Belgrade have been employed and one for the territory of courts in Vranje. No persons applied for the job of a sworn-to-court interpreter for the Ukrainian language. The High Judicial Council, under the proposal of the ministry in charge of judiciary, shall appoint lay-judges. A certain number of layjudges who are the members of the Romani and the Ukrainian national minorities has also been appointed lay-judges at the following courts: the Magistrate Court in Vranje - 2, the Magistrate Court in Leskovac - 1, the High Court in Leskovac 2 and the High Court in Niš - 2 lay-judges of the Romani nationality; the Magistrate Court in Sremska Mitrovica - one lay-judge of the Ukrainian nationality. The Section 2.4. of the Report contains the reasons of non-existence of any unit of local self-government in the Republic of Serbia in the territory of which the Romani and the Ukrainian languages are in the official use. Since the implementation of the Charter is considered to be an on-going process promoting the forms of use of minority languages, in the forthcoming period, as signified by the Provincial Secretariat for Regulations, Administration and National Minorities of AP of Vojvodina, a co-ordinated initiative of the ministries and the provincial bodies in charge of administration and local self-government and national minorities, should follow, as well as by the national councils of the Romani and the Ukrainian minorities, towards the units of local self-government where a considerable number of the members of the Ukrainian and the Romani national communities live, under the conditions of formal-legal and economic feasibility, to start the procedures to introduce these languages into the official use. 
46. All Part III languages of the Charter, which are in the official use, may be used in the relations with the offices of the state authorities in the administrative districts. However, this right has not been accomplished in practice due to the lack of applications by the speakers of minority languages who are the holders of this right. For example, on the grounds of the information obtained from all administrative districts in the territories where minority languages are in some form of official use, no application had been filed, which means that no administrative proceedings had been carried out in any of the minority languages.

Recommendation 6: take the necessary legal and practical measures to ensure that personal names and place names in the regional or minority languages can be used officially in conformity with the tradition and orthography of the languages concerned.

47. The information on legal and practical measures to ensure that personal names and place names in the regional or minority languages can be used officially in conformity with the tradition and orthography of the languages concerned are contained in the Sections 4.3.8. and 4.3.5. of this Report.

\subsection{Activities for the implementation of the box-recommendation of the Committee of Experts with regard to the implementation of the Charter}

48. In the Report on the implementation of the Charter in the first cycle of reporting, the Committee of Experts stated the following recommendation:

The Committee of Experts encourages the Serbian authorities to take steps to secure the implementation of the Charter in all municipal territories where the regional or minority languages are present in sufficient numbers for the application of provisions of the Charter, including where necessary changes to statutes of municipalities.

49. The regulations of the Republic of Serbia establish only the conditions in percents for the compulsory introduction into an equal use of some minority language and script in the unit of local self-government. Namely, the established percentage wise participation of $15 \%$, namely of $25 \%$ of the members of the national minorities in the total number of inhabitants in the territory of the unit of local self-government where some minority language and script is introduced into an equal use, namely in the territory of the settlement or local office in the territory of AP of Vojvodina, presents the bottom limit when the unit of local selfgovernment must introduce some minority language and script into an equal use according to the statute. However, numerous examples from practice the Committee of Experts also knows of, indicate that the condition of percentage wise participation of the members of national minorities in the units of local selfgovernment is not crucial for the introduction of some minority language and script into an equal use. 
50. Within the period after the first cycle of monitoring of the implementation of the Charter, by their statutes some units of local self-government established the new official use of minority languages, thus increasing the number of the units of local self-governments, namely the number of settlements or local communities where some of the minority languages is in the official use. The following paragraphs of the report contain the data on the official use of minority languages in the units of local self-government in the territory of the Republic of Serbia.

51. Albanian language and script are in official use in 3 municipalities: Bujanovac, Medveđa and Preševo.

52. Bosniak language and script are officially used in 4 units of local self-government in the town of Novi Pazar and in the municipalities of Prijepolje, Sjenica and Tutin. After the first cycle of monitoring of the implementation of the Charter, it was established that Bosniak language and script are officially used in the municipality of Prijepolje.

53. Bulgarian language and script are officially used in the municipalities of Bosilegrad and Dimitrovgrad. The Statute of the town of Pančevo prescribes the official use of Bulgarian language and script in the village of Ivanovo. After the first cycle of monitoring of the implementation of the Charter, it was established that Bulgarian language and script are officially used in Ivanovo.

54. Hungarian language and script are in official use in the entire territory of 28 towns and municipalities, such as: Ada, Bač, Bačka Topola, Bela Crkva, Bečej, Vrbas, Vršac, Žitište, Zrenjanin, Kanjiža, Kovačica, Kovin, Kula, Mali Iđoš, Nova Crnja, Novi Bečej, Novi Kneževac, Novi Sad, Odžaci, Plandište, Senta, Sečanj, Sombor, Srbobran, Subotica, Temerin, Titel and Čoka. In addition, Hungarian language is also in the official use in four settlements in the municipality of Kikinda (Banatska Topola, Kikinda, Rusko Selo and Sajan, two settlements in the municipality of Apatin (Kupusina, Svilojevo), as well as in the town of Pančevo in the cadastre municipality of Vojlovica and in the village of Ivanovo. After the first cycle of monitoring of the implementation of the Charter, the municipality of Vršac, through the amendments of the statute of the municipality, brought back Hungarian language and script into official use in the entire territory of the municipality at the beginning of 2008, which was officially used in certain dwelling areas until then, and it was also established to use Hungarian language and script in Vojlovica and Ivanovo.

55. Macedonian language is officially used in the settlement of Jabuka in the town of Pančevo and in the settlement of Dužine in the municipality of Plandište, which were introduced in the official use after the first cycle of monitoring of the implementation of the Charter.

56. Romanian language is officially used in the following nine towns and municipalities: Alibunar, Bela Crkva, Vršac, Žitište, Zrenjanin, Kovačica, Kovin, 
Plandište, Sečanj, as well as in the town of Pančevo, in the settlement of Banatsko Novo Selo. After the first cycle of monitoring of the implementation of the Charter, it was established that Romanian language and script are officially used in Banatsko Novo Selo, and the municipality of Vršac, through the amendments of its statute at the beginning of 2008 brought back Romanian language and script into the official use in the entire territory of the municipality, which was officially used in certain settlements until then.

57. Ruthenian language is in official use in Vrbas, Žabalj, Kula, Novi Sad and in Šid. In addition, this language is in official use in the settlement of Novo Orahovo in the municipality of Bačka Topola.

58. Slovak language is officially used in the entire territory of 10 towns and municipalities, as follows: Alibunar, Bač, Bačka Palanka, Bački Petrovac, Zrenjanin, Kovačica, Novi Sad, Odžaci, Plandište and Šid. This language is also officially used in the settlement of Stara Pazova (the municipality of Stara Pazova), in the settlements of Bajša (the municipality of Bačka Topola) and Lug (the municipality of Beočin).

59. Croatian language is officially used in the town of Subotica, as well as in the territory of the settlement of Stara Bingula (the town of Sremska Mitrovica), the settlements of Bački Breg and Bački Monoštor (the town of Sombor) and Sonta (the municipality of Apatin). After the first cycle of monitoring of the implementation of the Charter, it was established that Croat language and script are officially used in Bački Breg and Bački Monoštor.

60. Czech language is officially used in the municipality of Bela Crkva.

61. Romani and Ukrainian languages and scripts are not officially used in any unit of local self-government in the territory of the Republic of Serbia, namely in no settlement or local community in AP of Vojvodina, because they do not meet the requirements of percentage wise participation of the members of those national minorities in the total number of population of local communities. Namely, in the territory of the Republic of Serbia, according to the last 2002 census, there is no unit of local self-government where the number of the members of Romani and Ukrainian national minorities reaches $15 \%$ of the total number of population of unit of local self-government, and in the territory of AP of Vojvodina there is no settlement or local community where the number of members of Romani or Ukrainian national minority reaches $25 \%$ of the total number of population of settlement or local community. Although the national legislation prescribes the opportunity for the bodies of local self-government to introduce minority language and script into official use by means of their statutes, even if they do not meet the above mentioned requirement, according to the information provided by the state and the provincial bodies, there have been no concrete initiatives so far by the legitimate representative bodies of Romani and Ukrainian national minorities to introduce Romani and Ukrainian into official use, and units of local 
self-government, where there could be any sense to introduce these languages into official use, have not recognized on their own that it was justified to introduce them into official use. The newly elected national councils, as legitimate representatives of national minorities and holders of cultural autonomy, have the key role in making those initiatives, since the Law on the National Councils of the National Minorities also specifies competences of national councils in the proposals for establishing minority language and script as the official language in the units of local self-government (Article 22 item 3 of the Law).

62. However, it should be stressed that almost all bodies ensuring the right to the official use of minority language face financial problems, because it presents additional costs on their account, whereas this fact is not taken into account when planning the funds necessary for their activities. The method of financing of the bodies is the same in both the territory of those units of local self-government where no minority language is in the official use and the territory of those units where some minority language, or even several minority languages are introduced in the official use for which reason they have increased expenditures for translations, installation of adequate computer programmes, provision of forms, professional training of employees and similar activities. In order to mitigate financial difficulties of those units of local self-government providing the right to the official use of minority language, with the aim to improve multi-linguistics and for more efficient accomplishment of the right of citizens to use their languages, the Provincial Secretariat for Regulations, Administration and National Minorities of AP of Vojvodina issues tenders to finance, namely to participate in financing of training of employees with the bodies and organizations where they use minority language established to be officially used language, especially for training of those employees who make contacts with customers (attending courses, seminars and in other ways foreseen for the same purpose) and for the development of the system of electronic administration for activities under the conditions of multi-linguistics; costs of preparation and erection of boards with names of bodies and organizations, names of dwelling areas on roads, names of streets and squares written also in minority languages officially used in town, municipality or dwelling area, and for printing of bi-lingual and multi-lingual forms, as well as for printing of official gazettes and other public printed matter. The bodies of towns and municipalities explicitly in the territory of AP of Vojvodina could participate in the tender, where the official use of minority language and script is established by the statute in the entire territory of town, municipality or certain dwelling areas in their territory; local self-governments in the territory of towns and municipalities; other bodies, organizations, services and institutions in the territory of towns and municipalities. On the grounds of the relevant criteria, in 2008 the funds were transferred pursuant to 78 applications and in 2009 (in two tender cycles) the funds were transferred pursuant to 187 applications in the total amount of 22,650,000.00 dinars. It is necessary to stress that the method of preparation and acting according to the tender documentation until now show the importance and contribution of multi-linguistics. Namely, the text of the tender and the application forms for the tender are prepared and 
published in Serbian language and Cyrillic script, then in Hungarian, Slovak, Croat, Romanian and Ruthenian languages and scripts. The tender documentation in those languages could be found on the official website of the Secretariat for regulations, Administration and National Minorities, a copy of the tender documentation is also sent to all town and municipal administration in AP of Vojvodina where some minority language is officially used (39 of 45 administrations), which further deliver it to the local self-governments in their territory. The tender is also published in the newspapers published in minority languages. The national councils of the Hungarian, Slovak, Croat, Romanian and Ruthenian national minorities are informed about the tender including documentation. The tender applications and the documentation for the tender issued in 2008 were mainly in Serbian language. In the meantime there has been noticeable progress so that for the latest tender half of the received applications were in Hungarian language from the communities where Hungarian is officially used and there were several applications in Croat language. It is also noticed that there is an increased number of reports on the funds spent (although only in Hungarian language and script). 


\section{PART II. IMPLEMENTATION OF ARTICLE 7 OF THE CHARTER}

\subsection{Information on the policy, legislation and practice in the implementation of Part II - Article 7 of the Charter}

\section{Article 7 \\ Objectives and principles}

1. In respect of regional or minority languages, within the territories in which such languages are used and according to the situation of each language, the Parties shall base their policies, legislation and practice on the following objectives and principles:

a) the recognition of the regional or minority languages as an expression of cultural wealth;

b) the respect for the geographical area of each regional or minority language in order to ensure that existing or new administrative divisions do not constitute an obstacle to the promotion of the regional or minority language in question;

c) the need for resolute action to promote regional or minority languages in order to safeguard them;

d) the facilitation and/or encouragement of the use of regional or minority languages, in speech and writing, in public and private life;

e) the maintenance and development of links, in the fields covered by this Charter, between groups using a regional or minority language and other groups in the State employing a language used in identical or similar form, as well as the establishment of cultural relations with other groups in the State using different languages;

f) the provision of appropriate forms and means for the teaching and study of regional or minority languages at all appropriate stages;

g) the provision of facilities enabling non-speakers of a regional or minority language living in the area where it is used to learn it if they so desire;

$\boldsymbol{h})$ the promotion of study and research on regional or minority languages at universities or equivalent institutions;

i) the promotion of appropriate types of transnational exchanges, in the fields covered by this Charter, for regional or minority languages used in identical or similar form in two or more States.

2. The Parties undertake to eliminate, if they have not yet done so, any unjustified 
distinction exclusion, restriction or preference relating to the use of a regional or minority language and intended to discourage or endanger the maintenance or development of it. The adoption of special measures in favour of regional or minority languages aimed at promoting equality between the users of these languages and the rest of the population or which take due account of their specific conditions is not considered to be an act of discrimination against the users of more widely-used languages.

3. The Parties undertake to promote, by appropriate measures, mutual understanding between all the linguistic groups of the country and in particular the inclusion of respect, understanding and tolerance in relation to regional or minority languages among the objectives of education and training provided within their countries and encouragement of the mass media to pursue the same objective.

4. In determining their policy with regard to regional or minority languages, the Parties shall take into consideration the needs and wishes expressed by the groups which use such languages. They are encouraged to establish bodies, if necessary, for the purpose of advising the authorities on all matters pertaining to regional or minority languages.

5. The Parties undertake to apply, mutatis mutandis, the principles listed in paragraphs 1 to 4 above to non-territorial languages. However, as far as these languages are concerned, the nature and scope of the measures to be taken to give effect to this Charter shall be determined in a flexible manner, bearing in mind the needs and wishes, and respecting the traditions and characteristics, of the groups which use the languages concerned.

\subsubsection{Recognition of minority language as cultural wealth}

63. The most significant measures recognizing minority languages as an expression of cultural wealth in the Republic of Serbia have the aim to preserve minority languages, and they consist of studying minority languages, promotion of their use, as well as of financial support and other forms of support to information and works in minority languages. Such measures are explained in the Sections 3.2. and 4.1, 4.4. and 4.5. of the Report.

64. In the Republic of Serbia special manifestations are also organized presenting minority languages explicitly as an expression of cultural wealth. Every year, an increasingly larger number of organizations, schools, competent state and provincial bodies, as well as of units of local self-governments, especially those having mixed national composition, mark through different manifestations the International Day of Mother Tongue - 21 February. The aim of these manifestations is to show that there are linguistic differences and to improve awareness and tolerance in the society related to minority languages on one side and to preserve and develop minority languages, as the most powerful instrument for the protection of identity and culture of those who use then, on the other side. Since 2009 the Ministry of Human and Minority Rights has joined the celebration 
of the International Day of Mother Tongue, which is marked in co-operation with the national councils of national minorities.

\subsubsection{Respect for the geographical areas of minority languages}

65. Respect for geographic areas of certain minority languages has also been regained in the new Law on Territorial Organization of the Republic of Serbia, which was adopted in 2007. The adoption of this Law was the base for the establishment of the new system of provincial autonomy and local self-government, and no new territorial units were established in the new legal solutions, but the existing ones were kept, whereas it is prescribed that also those units of local self-government that do not meet the criteria in respect of minimum number of population still exist as municipalities, provided they were formed before this Law enter into force. The basic solutions of this Law define territorial organization of the Republic of Serbia, the notion of municipal territory, town and city of Belgrade and their borders. This Law also defines the grounds for establishment of new units of local self-government, merger, cancellation and change of territory of the existing ones, whereas an essential novelty is that the establishment of new units of local self-government, cancellation and change of territory of the existing ones is only possible according to the previously held referendum in the territory of the unit of the local self-government concerned. The Law prescribes that the procedure of establishment, merger and cancellation of municipalities, as well as the changes of their territory, pursuant to the Constitution, must be preceded by referendum, which is of advisory character. The change of territorial organization may be initiated by assemblies of municipalities or $10 \%$ of voters who have residence in the territory of the municipality the change relates to, and it may also be proposed by the authorized proposers of the law.

66. As stated in the Section 4.1.2.1. of the First Periodic Report on the implementation of the Charter, in the Republic of Serbia there is no policy with the aim to create obstacles for the promotion of minority languages and, according to the opinion of the power, the existing division of powers does not present an obstacle for the promotion of minority languages, either. The new Law on Territorial Organization of the Republic of Serbia does not form new territorial units, and there is no change of the territory of the existing units of local selfgovernment, either. Also, during the implementation of previous law, and during the implementation of the law in force, none of the national minorities, including also the Bulgarian, made initiative to change the territory of municipalities.

\subsubsection{Resolute action to promote minority languages}

67. Action to promote minority languages with the aim to protect them includes the application of measures to promote full and effective equality based on the constitutional and legal provisions specified in the statement-of-reasons for the application of Article 7 paragraph 2 of the Charter. Creation and application of 
such measures should be carried out in co-operation with the relevant bodies the competences of which are explained in the Section 2.2.2. of this Report.

\subsubsection{Provision of conditions to facilitate and/or promote the use of minority languages}

68. The Republic of Serbia, aware of importance of preservation and development of minority languages as a segment of its minority policy, whose final aim is the integration of national minorities in social life, together with further preservation and development of their national and cultural specificies, pays particular attention to the provision of conditions to facilitate and/or encourage the use of minority languages. It is achieved by continuous monitoring of legal regulations and by elimination of observed deficiencies aggravating their application.

69. A series of system laws, which regulate the method of achievement of the right guaranteed by the Constitution to use minority languages, is explained in the relevant parts of the Report.

\subsubsection{Establishment of cultural links between the groups speaking minority languages}

70. The establishment of cultural links between the groups speaking minority languages is explained in the comment on the implementation of Article 1, sub-Article $\mathrm{g}$ and paragraph 3 .

\subsubsection{Provision of the study of minority languages}

71. The data on the practice of study of minority languages of Part III of the Charter at adequate levels and academic bodies, which ensure their studying at the level of university education, are contained in the Section 4.1 of this Report. The data on the practice of study of other minority languages and about academic bodies ensuring their study at the level of university education, are contained in the Section 3.2. of this Report.

\subsubsection{Facilitation of the study of minority languages}

72. In the Section 4.1.7. of the First Periodic Report on the implementation of the Charter, the legislative framework for the implementation of the curricula in minority language is stated, as well as the legislative framework for the provision of the curricula of mother tongue with elements of national culture during primary and secondary education. Such solutions created the possibilities for those who do not speak minority languages but live in the area where these languages are spoken, to learn them, if they wish to do so. The questionnaire conducted by the Provincial Secretariat of Education of AP of Vojvodina on national affiliation of children/pupils and the progress of their education and up-brining in certain minority languages shows that the number of pupils studying minority languages 
does not coincide with the national structure and that there are cases of studying of minority languages by those who do not use them as mother tongue, namely by those who do not speak them. On the grounds of this questionnaire it is possible to monitor availability of education in certain minority languages in the territory of AP of Vojvodina to those who are not native speakers of such languages as well. The following tables contain the data on national affiliation of children /pupils who attend school in certain minority languages in the territory of AP of Vojvodina.

\section{National affiliation of the children attending preparatory pre-school programme} conducted in minority languages in the 2009/2010 school year

\begin{tabular}{|c|c|c|c|c|c|c|c|c|c|c|c|c|c|c|c|c|c|c|c|c|}
\hline \multicolumn{21}{|c|}{ EDUCATION IN HUNGARIAN LANGUAGE } \\
\hline $\begin{array}{l}\hat{0}^{n} \\
\overline{0} \\
\tilde{n}\end{array}$ & 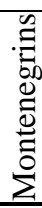 & 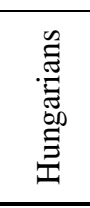 & $\frac{\hat{y}}{\tilde{c}} \frac{0}{\tilde{c}}$ & 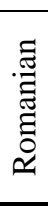 & 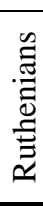 & 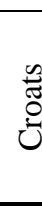 & 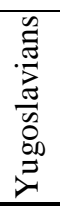 & 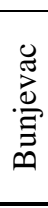 & 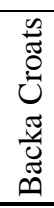 & 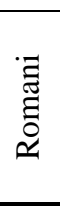 & 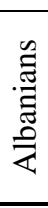 & 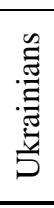 & 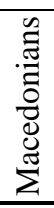 & 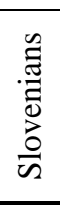 & 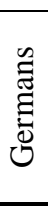 & 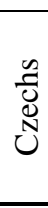 & 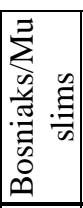 & 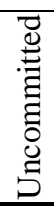 & $\frac{\mathscr{d}}{\stackrel{D}{0}}$ & 疍 \\
\hline
\end{tabular}

\begin{tabular}{|c|c|c|c|c|c|c|c|c|c|c|c|c|c|c|c|c|c|c|c|c|}
\hline \multicolumn{21}{|c|}{ EDUCATION IN SERBIAN AND HUNGARIAN LANGUAGES } \\
\hline $\begin{array}{l}n \\
\stackrel{0}{0} \\
n\end{array}$ & 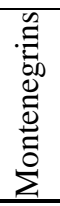 & 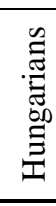 & $\begin{array}{l}\frac{n}{n} \\
\frac{n}{n} \\
\tilde{a}\end{array}$ & 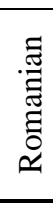 & 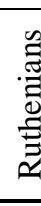 & $\begin{array}{l}\stackrel{0}{0} \\
\stackrel{0}{0}\end{array}$ & 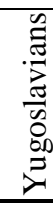 & 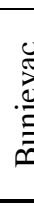 & 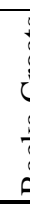 & & . & $\cdot \frac{\pi}{\Xi}$ & 西 & 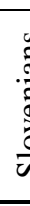 & 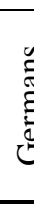 & 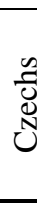 & 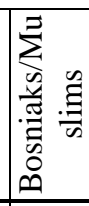 & 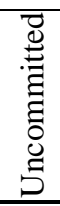 & 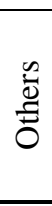 & 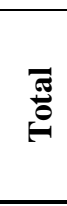 \\
\hline 54 & 1 & 98 & 0 & 0 & 1 & 1 & 1 & 2 & 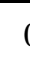 & 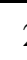 & 0 & 0 & 0 & 0 & 0 & 0 & 0 & 5 & 0 & 165 \\
\hline
\end{tabular}

\begin{tabular}{|c|c|c|c|c|c|c|c|c|c|c|c|c|}
\hline \multicolumn{13}{|c|}{ EDUCATION IN UNGARIAN AND GERMAN LANGUAGES } \\
\hline 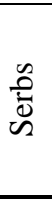 & 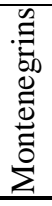 & 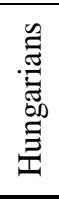 & $\begin{array}{l}\frac{n}{n} \\
\frac{\partial}{n}\end{array}$ & 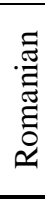 & 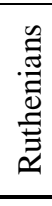 & $\begin{array}{l}\tilde{\tilde{J}} \\
\stackrel{0}{U}\end{array}$ & 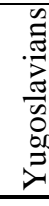 & 苞 & 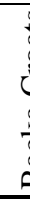 & & & $\stackrel{\bar{\sigma}}{\theta}$ \\
\hline 0 & 0 & 1 & 0 & 0 & 0 & 0 & 1 & 0 & 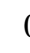 & 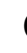 & & 3 \\
\hline
\end{tabular}


EDUCATION IN ROMANIAN LANGUAGE

\begin{tabular}{|c|c|c|c|c|c|c|c|c|c|c|c|c|c|c|c|c|c|c|c|c|}
\hline $\begin{array}{l}0 \\
\overline{0} \\
\tilde{D}\end{array}$ & 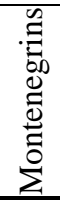 & 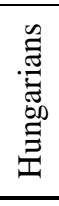 & $\begin{array}{l}\frac{n}{\tilde{w}} \\
\frac{\partial}{\tilde{v}} \\
\end{array}$ & 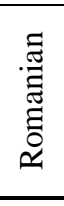 & 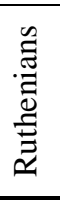 & $\begin{array}{l}\stackrel{0}{0} \\
\stackrel{0}{0}\end{array}$ & 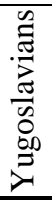 & 苛 & 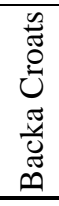 & 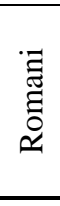 & . & 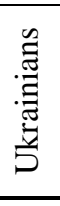 & 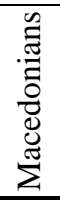 & 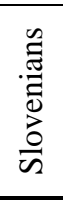 & 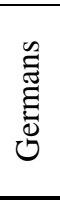 & 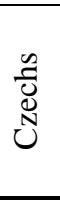 & 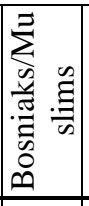 & 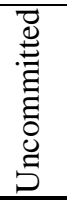 & $\begin{array}{l}\text { 节 } \\
\text { tँ }\end{array}$ & 吾 \\
\hline 0 & 0 & 0 & 0 & 120 & 0 & 0 & 0 & 0 & 0 & 0 & 0 & 0 & 0 & 0 & V & 0 & 0 & 0 & 0 & 120 \\
\hline
\end{tabular}

\begin{tabular}{|c|c|c|c|c|c|c|c|c|c|c|c|c|c|c|c|c|c|c|c|c|}
\hline \multicolumn{21}{|c|}{ EDUCATION IN SERBIAN AND ROMANIAN LANGUAGES } \\
\hline $\begin{array}{l}0 \\
\overline{0} \\
\tilde{D}\end{array}$ & 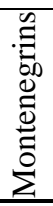 & 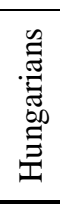 & $\begin{array}{l}\frac{n}{\pi} \\
\frac{\partial}{n} \\
n\end{array}$ & 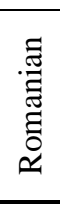 & 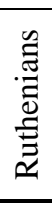 & 苛 & 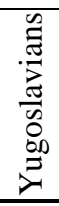 & 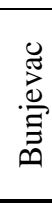 & 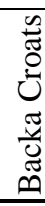 & 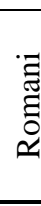 & $\begin{array}{l}\text {. } \\
\text { ]్ } \\
\text { ह }\end{array}$ & 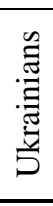 & 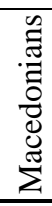 & 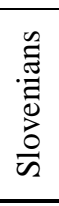 & 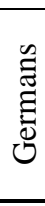 & $\begin{array}{l}\frac{\tilde{a}}{\tilde{U}} \\
\text { UN }\end{array}$ & 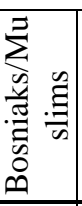 & 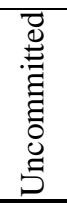 & $\begin{array}{l}\text { 离 } \\
\text { ప̃ }\end{array}$ & 吾 \\
\hline 40 & 0 & 1 & 1 & 40 & 0 & 0 & 0 & 0 & 0 & 4 & 0 & 0 & 0 & 0 & 0 & 0 & 0 & 0 & 0 & 86 \\
\hline
\end{tabular}

\begin{tabular}{|c|c|c|c|c|c|c|c|c|c|c|c|c|c|c|c|c|c|c|c|c|}
\hline \multicolumn{21}{|c|}{ EDUCATION IN RUTHENIAN LANGUAGE } \\
\hline $\begin{array}{l}0 \\
\stackrel{0}{\nu} \\
\tilde{n}\end{array}$ & 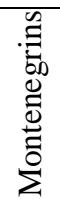 & 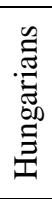 & $\begin{array}{l}\frac{n}{\tilde{w}} \\
\frac{\partial}{\omega}\end{array}$ & 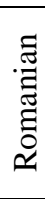 & 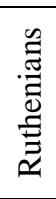 & 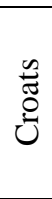 & 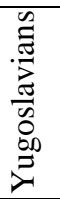 & 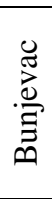 & 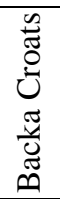 & 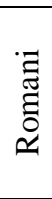 & 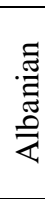 & 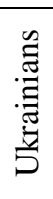 & 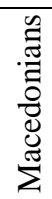 & 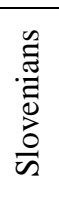 & 节 & 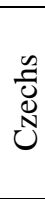 & 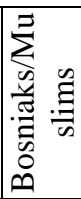 & 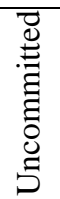 & 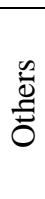 & $\stackrel{\bar{\Xi}}{0}$ \\
\hline 3 & 0 & 0 & 0 & 0 & 87 & 0 & 0 & 0 & 0 & 3 & 0 & 0 & 0 & 0 & 0 & 0 & 2 & 0 & 0 & 95 \\
\hline
\end{tabular}

\begin{tabular}{|c|c|c|c|c|c|c|c|c|c|c|c|c|c|c|c|c|c|c|c|c|}
\hline \multicolumn{21}{|c|}{ EDUCATION IN SLOVAK LANGUAGE } \\
\hline $\begin{array}{l}\stackrel{\infty}{\bar{D}} \\
\stackrel{D}{n}\end{array}$ & 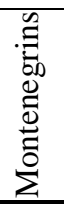 & 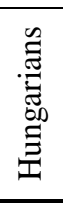 & $\begin{array}{l}\frac{\tilde{v}}{\tilde{\sigma}} \\
\frac{0}{\tilde{n}}\end{array}$ & 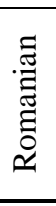 & 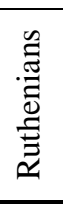 & $\begin{array}{l}\stackrel{n}{0} \\
\stackrel{0}{0}\end{array}$ & 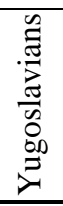 & 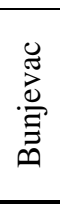 & 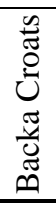 & $\begin{array}{l}\text { 䛃 } \\
\text { है }\end{array}$ & $\begin{array}{l}\text {. } \\
\text { हैँ } \\
\text { है }\end{array}$ & 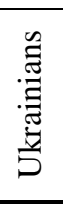 & 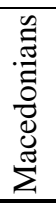 & 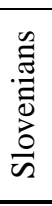 & 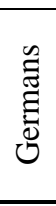 & $\begin{array}{l}\frac{\pi}{\bar{J}} \\
\text { J }\end{array}$ & 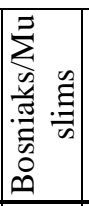 & 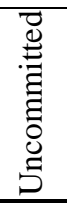 & 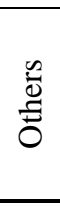 & 丞 \\
\hline 18 & 0 & 0 & 378 & 0 & 0 & 0 & 0 & 0 & 0 & 1 & 0 & 0 & 0 & 0 & 0 & 0 & 0 & 4 & 0 & 401 \\
\hline 18 & 0 & 0 & 378 & 0 & 0 & 0 & 0 & 0 & 0 & 1 & 0 & 0 & 0 & 0 & 0 & 0 & 0 & 4 & 0 & 401 \\
\hline
\end{tabular}




\begin{tabular}{|c|c|c|c|c|c|c|c|c|c|c|c|c|c|c|c|c|c|c|c|c|}
\hline 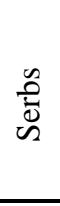 & 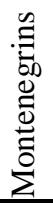 & 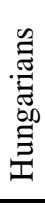 & $\begin{array}{l}\frac{n}{n} \\
\frac{\tilde{v}}{n} \\
\frac{0}{n}\end{array}$ & 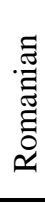 & 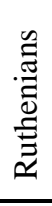 & 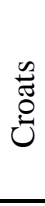 & 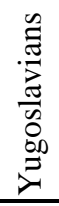 & 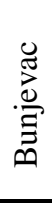 & 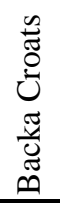 & $\begin{array}{l}\tilde{\Xi} \\
\tilde{\Xi} \\
\simeq \\
\simeq\end{array}$ & 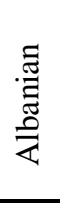 & 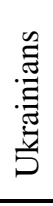 & 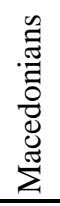 & 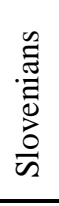 & 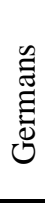 & 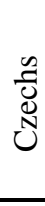 & 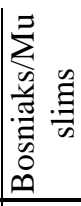 & 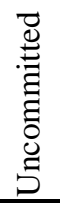 & 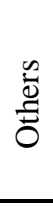 & 窇 \\
\hline 23 & 0 & 0 & 15 & 0 & 0 & 0 & 0 & 0 & 0 & 0 & 0 & 0 & 0 & 0 & 0 & 0 & 0 & 0 & 0 & 38 \\
\hline
\end{tabular}

\begin{tabular}{|c|c|c|c|c|c|c|c|c|c|c|c|c|c|c|c|c|c|}
\hline \multicolumn{18}{|c|}{ EDUCATION IN CROATIAN LANGUAGE } \\
\hline $\begin{array}{l}\stackrel{0}{\bar{D}} \\
\stackrel{0}{n}\end{array}$ & 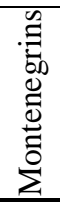 & 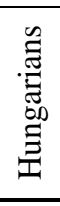 & $\begin{array}{l}\frac{n}{5} \\
\frac{n}{n} \\
\end{array}$ & 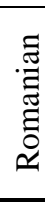 & 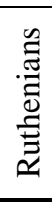 & 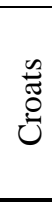 & 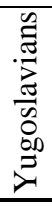 & : & 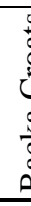 & 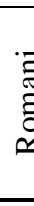 & & & & 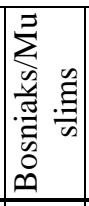 & 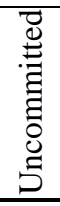 & 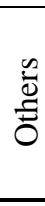 & 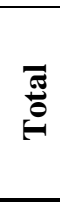 \\
\hline 0 & 0 & 0 & 0 & 0 & 0 & 25 & 0 & 2 & ( & 0 & & 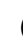 & & 0 & 0 & 0 & 27 \\
\hline
\end{tabular}

\begin{tabular}{|c|c|c|c|c|c|c|c|c|c|c|c|c|c|c|c|c|c|c|c|c|}
\hline \multicolumn{21}{|c|}{ EDUCATION IN SERBIAN AND GERMAN LANGUAGES } \\
\hline $\begin{array}{l}0 \\
\stackrel{0}{\vec{v}} \\
\tilde{n}\end{array}$ & 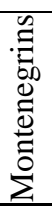 & 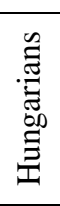 & $\begin{array}{l}\frac{v}{n} \\
\frac{a}{v} \\
\frac{a}{n}\end{array}$ & 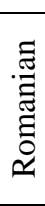 & 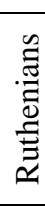 & $\begin{array}{l}\tilde{\Xi} \\
\dot{0} \\
\dot{U}\end{array}$ & 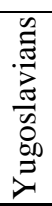 & 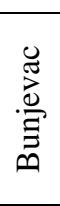 & 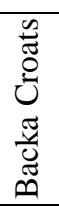 & 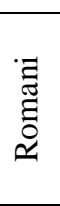 & 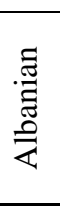 & 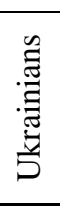 & 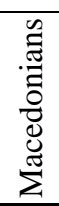 & 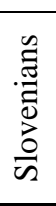 & 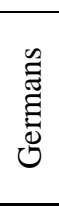 & $\begin{array}{l}\text { 岕 } \\
\text { UN }\end{array}$ & 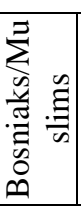 & 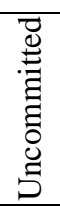 & 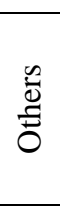 & : \\
\hline 6 & 0 & 0 & 0 & 0 & 1 & 0 & 0 & 0 & 0 & 0 & 0 & 0 & 0 & 0 & 0 & 0 & 0 & 1 & 0 & 8 \\
\hline
\end{tabular}

73. The possibility of studying minority languages also exists at primary and secondary schools. The following Tables contain the data about national affiliation of pupils(students) whose primary education is conducted in the following minority languages in the territory of AP of Vojvodina

National affiliation of pupils attending primary schools in the minority languages in the $2009 / 2010$ school year

\begin{tabular}{|c|c|c|c|c|c|c|c|c|c|c|c|c|c|c|c|c|c|c|c|}
\hline \multicolumn{20}{|c|}{ EDUCATION IN HUNGARIAN LANGUAGE } \\
\hline $\begin{array}{l}\stackrel{\tilde{0}}{\tilde{D}} \\
\tilde{n}\end{array}$ & 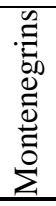 & 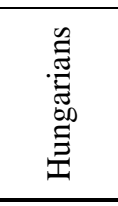 & 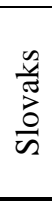 & 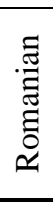 & 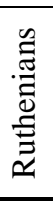 & 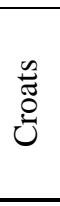 & 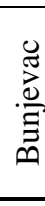 & 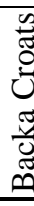 & $\begin{array}{l}\tilde{\Xi} \\
\bar{\Xi} \\
\tilde{a}\end{array}$ & 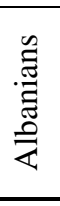 & 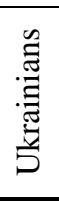 & 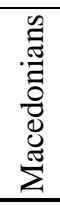 & 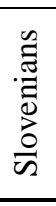 & $\begin{array}{l}\tilde{E} \\
\tilde{\Xi} \\
\tilde{D}\end{array}$ & 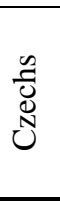 & 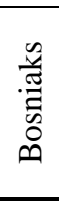 & 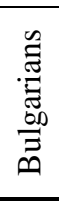 & 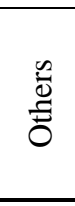 & 囟 \\
\hline 56 & 1 & 15,516 & 16 & 0 & 0 & 25 & 18 & 0 & 379 & 5 & 2 & 1 & 1 & 0 & 0 & 0 & 1 & 147 & 16,168 \\
\hline
\end{tabular}




\begin{tabular}{|c|c|c|c|c|c|c|c|c|c|c|c|c|c|c|c|c|c|c|c|}
\hline $\begin{array}{l}n \\
\stackrel{0}{0} \\
\tilde{n}\end{array}$ & 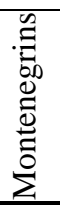 & 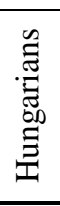 & 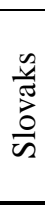 & 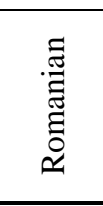 & 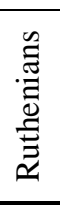 & $\begin{array}{l}\stackrel{\mathscr{J}}{0} \\
\stackrel{0}{0}\end{array}$ & 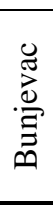 & 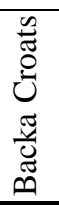 & 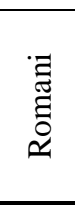 & 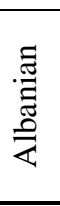 & 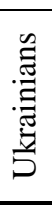 & 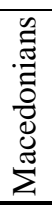 & 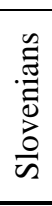 & 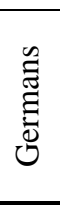 & $\begin{array}{l}\text { 先 } \\
\text { N } \\
\text { Un }\end{array}$ & 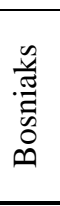 & 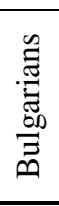 & 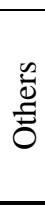 & 㐫 \\
\hline 21 & 0 & 3 & 0 & 1,092 & 0 & 0 & 0 & 0 & 133 & 0 & 0 & 2 & 0 & 0 & 0 & 0 & 0 & 7 & 1,258 \\
\hline
\end{tabular}

\begin{tabular}{|c|c|c|c|c|c|c|c|c|c|c|c|c|c|c|c|c|c|c|c|}
\hline \multicolumn{20}{|c|}{ EDUCATION IN RUTHENIAN LANGUAGE } \\
\hline $\begin{array}{l}0 \\
\stackrel{0}{0} \\
\tilde{n}\end{array}$ & 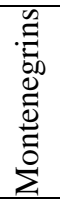 & 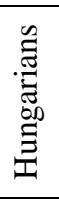 & $\begin{array}{l}\frac{\tilde{v}}{\tilde{N}} \\
\frac{\vec{\sigma}}{\omega}\end{array}$ & 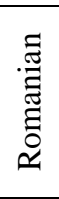 & 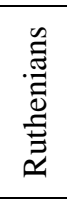 & $\begin{array}{l}\tilde{\Xi} \\
\stackrel{0}{0} \\
\text { Un }\end{array}$ & 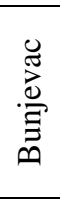 & 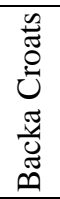 & 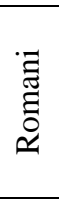 & 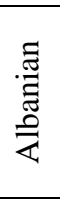 & 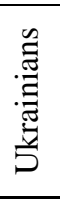 & 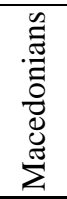 & 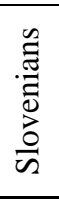 & $\begin{array}{l}\tilde{E} \\
\text { हूँ } \\
\text { हू }\end{array}$ & $\begin{array}{l}\tilde{U} \\
\tilde{D} \\
\tilde{J}\end{array}$ & 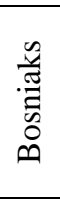 & 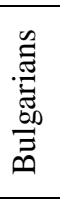 & 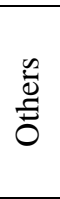 & $\stackrel{\bar{\sigma}}{0}$ \\
\hline 28 & 1 & 16 & 4 & 0 & 446 & 3 & 0 & 0 & 18 & 2 & 2 & 0 & 0 & 0 & 0 & 1 & 0 & 2 & 523 \\
\hline
\end{tabular}

\begin{tabular}{|c|c|c|c|c|c|c|c|c|c|c|c|c|c|c|c|c|c|c|c|}
\hline \multicolumn{20}{|c|}{ EDUCATION IN SLOVAK LANGUAGE } \\
\hline $\begin{array}{l}0 \\
\stackrel{0}{ \pm} \\
\tilde{D}\end{array}$ & 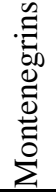 & 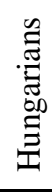 & $\begin{array}{l}\frac{n}{\pi} \\
\frac{a}{n} \\
\frac{0}{n}\end{array}$ & 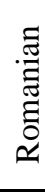 & 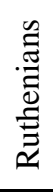 & 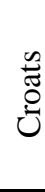 & 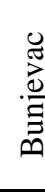 & 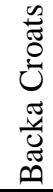 & 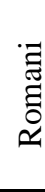 & 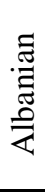 & 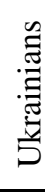 & 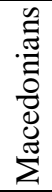 & 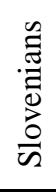 & 节 & 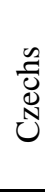 & 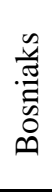 & 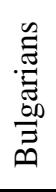 & $\frac{\tilde{d}}{\tilde{\Xi}}$ & 吾 \\
\hline 31 & 3 & 3 & 3,062 & 0 & 2 & 3 & 0 & 0 & 32 & 1 & 0 & 0 & 0 & 0 & 0 & 0 & 0 & 41 & 3,178 \\
\hline
\end{tabular}

\begin{tabular}{|c|c|c|c|c|c|c|c|c|c|c|c|c|c|c|c|c|c|c|c|}
\hline \multicolumn{20}{|c|}{$\begin{array}{l}\text { EDUCATION IN CROATIAN LANGUAGE } \\
\text { (The data refer to the } 2008 / 2009 \text { school year) }\end{array}$} \\
\hline 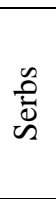 & 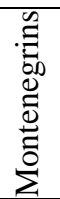 & 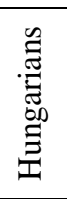 & 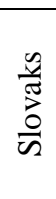 & 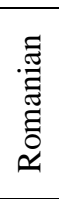 & 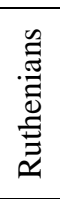 & $\begin{array}{l}\stackrel{0}{0} \\
\stackrel{0}{U}\end{array}$ & 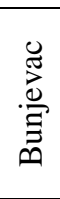 & 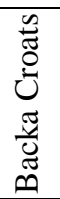 & 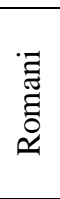 & 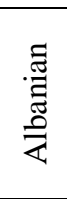 & 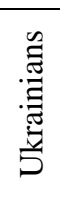 & 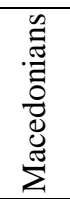 & 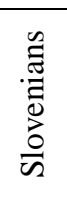 & 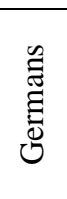 & 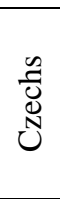 & 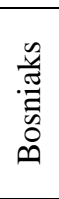 & 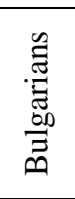 & 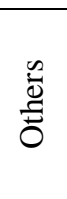 & $\stackrel{\frac{\pi}{0}}{\theta}$ \\
\hline 1 & 0 & 3 & 0 & 0 & 0 & 311 & 3 & 0 & 0 & 0 & 0 & 0 & 0 & 0 & 0 & 0 & 0 & 1 & 319 \\
\hline
\end{tabular}

Primary school pupils according to national affiliation and language of instruction in the 2009/2010 school year

\begin{tabular}{|l|l|l|l|l|l|l|l|l|}
\hline & \multicolumn{9}{|c|}{ Number of Hungarian pupils who are educated in: } & $\begin{array}{l}\text { Total } \\
\text { number of } \\
\text { pupils who } \\
\text { are } \\
\text { educated } \\
\text { in the }\end{array}$ & $\begin{array}{l}\text { Number of } \\
\text { pupils who } \\
\text { are } \\
\text { educated in } \\
\text { Hungarian } \\
\text { language } \\
\text { and did not } \\
\text { TOmber of } \\
\text { Hungarian }\end{array}$ & & & & & & & \\
\cline { 2 - 6 }
\end{tabular}




\begin{tabular}{|l|l|l|l|l|l|l|l|l|}
\hline & pupils & $\begin{array}{l}\text { Hungarian } \\
\text { language }\end{array}$ & $\begin{array}{l}\text { Serbian } \\
\text { language }\end{array}$ & $\begin{array}{l}\text { Slovak } \\
\text { language } \\
\text { language }\end{array}$ & $\begin{array}{l}\text { Romanian } \\
\text { language }\end{array}$ & $\begin{array}{l}\text { Croatian } \\
\text { language }\end{array}$ & $\begin{array}{l}\text { Hungarian } \\
\text { language } \\
\text { Hungarian } \\
\text { as their } \\
\text { nationality }\end{array}$ \\
\hline Total & 19,435 & 15,516 & 3,894 & 3 & 3 & 16 & 3 & 16,168 \\
\hline
\end{tabular}

\begin{tabular}{|c|c|c|c|c|c|c|c|c|c|}
\hline & \multirow[b]{2}{*}{$\begin{array}{l}\text { TOTAL } \\
\text { number of } \\
\text { Romanian } \\
\text { pupils }\end{array}$} & \multicolumn{6}{|c|}{ Number of Romanian pupils who are educated in: } & \multirow{2}{*}{$\begin{array}{l}\text { Total } \\
\text { number of } \\
\text { pupils who } \\
\text { are } \\
\text { educated in } \\
\text { the } \\
\text { Romanian } \\
\text { language }\end{array}$} & \multirow{2}{*}{$\begin{array}{l}\text { Number of } \\
\text { pupils who } \\
\text { are } \\
\text { educated in } \\
\text { Romanian } \\
\text { language } \\
\text { and did not } \\
\text { cite } \\
\text { Romanian } \\
\text { as their } \\
\text { nationality }\end{array}$} \\
\hline & & $\begin{array}{l}\text { Hungarian } \\
\text { language }\end{array}$ & $\begin{array}{l}\text { Serbian } \\
\text { language }\end{array}$ & $\begin{array}{l}\text { Slovak } \\
\text { language }\end{array}$ & $\begin{array}{l}\text { Romanian } \\
\text { language }\end{array}$ & $\begin{array}{l}\text { Ruthenian } \\
\text { language }\end{array}$ & $\begin{array}{l}\text { Croatian } \\
\text { language }\end{array}$ & & \\
\hline Total & 2.008 & 0 & 916 & 0 & 1.092 & 0 & 0 & 1.258 & 166 \\
\hline
\end{tabular}

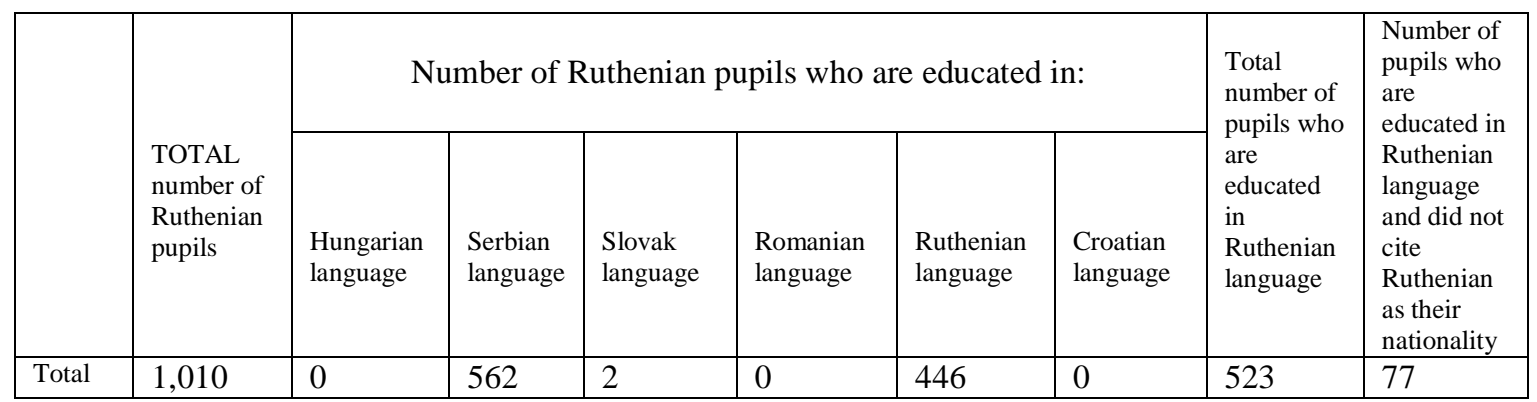

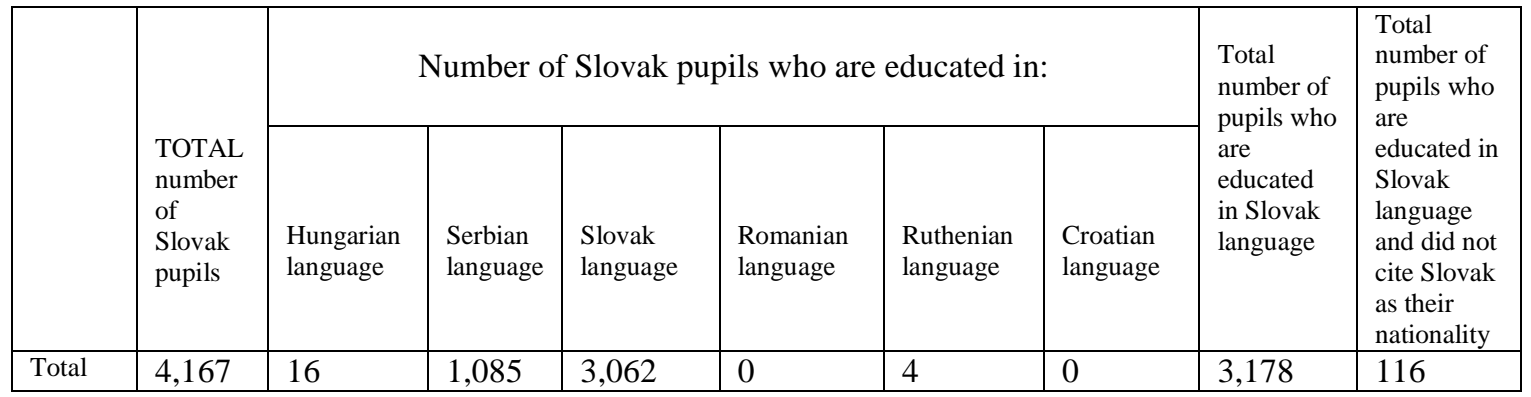

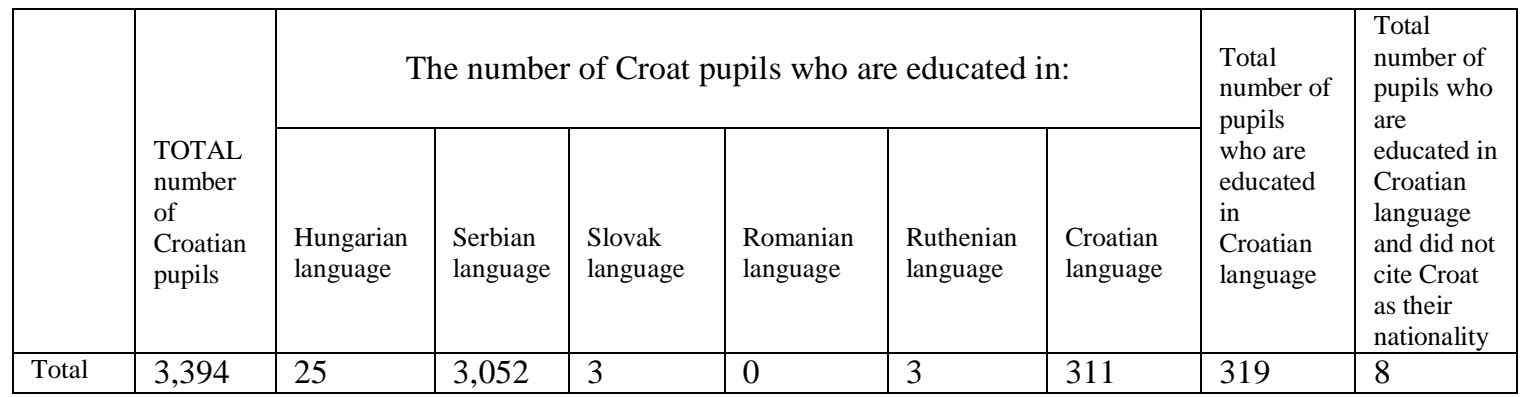

74. The Provincial Secretariat of Education of AP of Vojvodina made a proposal to include in the Rules on the Curricula for the second cycle of primary education all minority languages officially used- as a compulsory optional teaching subject. This proposal was addressed to the Minister of Education for approval. A proposal was also made to introduce teaching subject of Social Environment Language into the list of teaching subjects in the first and the second cycles of 
primary education and up-bringing including curricula proposals, in order to enable the pupils living in the area where there is a large number of members of the national minorities and in the classes where teaching is conducted in Serbian language to study minority languages.

75. There is also a possibility to study minority languages at the level of secondary school. The following tables contain the data on national affiliation of pupils attending secondary schools entirely in certain minority languages in the territory of AP of Vojvodina in the 2009/2010 school year.

National structure of pupils attending secondary schools where education is conducted in one of the minority languages in the 2009/2010 school year

\begin{tabular}{|c|c|c|c|c|c|c|c|c|c|c|c|c|c|c|c|c|c|c|c|}
\hline \multicolumn{20}{|c|}{ Hungarian language } \\
\hline 离 & 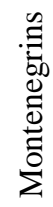 & 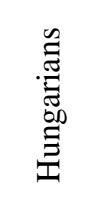 & $\begin{array}{l}\frac{n}{\tilde{w}} \\
\frac{\tilde{a}}{v}\end{array}$ & 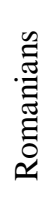 & 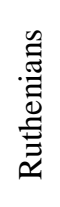 & $\begin{array}{l}\tilde{\Xi} \\
\stackrel{0}{0} \\
\tilde{U}\end{array}$ & 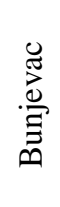 & 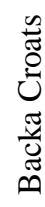 & 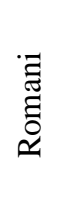 & 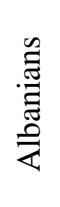 & 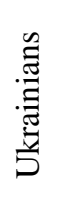 & 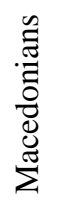 & 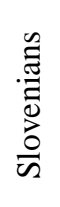 & 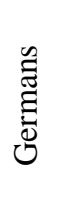 & $\begin{array}{l}\frac{n}{0} \\
\text { N } \\
\text { Un }\end{array}$ & 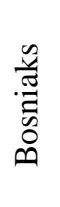 & 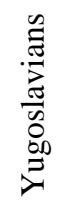 & 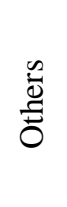 & 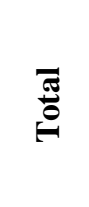 \\
\hline 37 & 0 & 6,406 & 1 & 0 & 1 & 21 & 6 & 0 & 22 & 1 & 0 & 1 & 2 & 1 & 0 & 0 & 28 & 52 & 6,579 \\
\hline
\end{tabular}

\begin{tabular}{|c|c|c|c|c|c|c|c|c|c|c|c|c|c|c|c|c|c|c|c|}
\hline \multicolumn{20}{|c|}{ Romanian language } \\
\hline $\begin{array}{l}0 \\
\stackrel{0}{0} \\
\tilde{n}\end{array}$ & 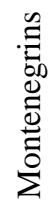 & 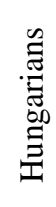 & $\begin{array}{l}\frac{n}{\sigma} \\
\frac{0}{n} \\
\frac{0}{n}\end{array}$ & 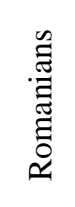 & 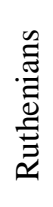 & $\begin{array}{l}\stackrel{0}{\tilde{\Xi}} \\
\stackrel{0}{0}\end{array}$ & 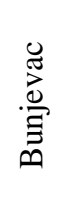 & 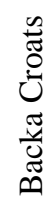 & 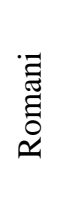 & 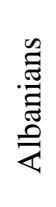 & 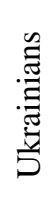 & 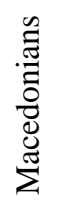 & 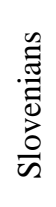 & 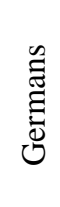 & 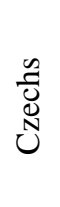 & 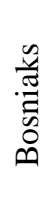 & 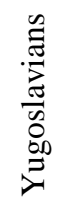 & $\frac{\tilde{\Xi}}{\tilde{\Xi}}$ & $\begin{array}{l}\overline{\frac{\pi}{0}} \\
\stackrel{\theta}{0}\end{array}$ \\
\hline 0 & 0 & 0 & 0 & 240 & 0 & 0 & 0 & 0 & 0 & 0 & 0 & 0 & 0 & 0 & 0 & 0 & 0 & 0 & 240 \\
\hline
\end{tabular}

\begin{tabular}{|c|c|c|c|c|c|c|c|c|c|c|c|c|c|c|c|c|c|c|c|}
\hline \multicolumn{20}{|c|}{ RUTHENIAN LANGUAGE } \\
\hline 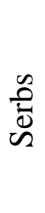 & 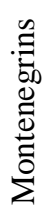 & 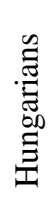 & $\begin{array}{l}\frac{\tilde{v}}{\pi} \\
\frac{\tilde{\sigma}}{\tilde{\omega}}\end{array}$ & 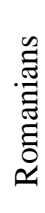 & 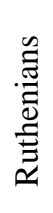 & 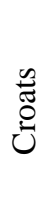 & 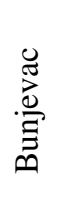 & 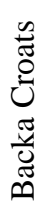 & $\begin{array}{l}\text { 'ี } \\
\text { है } \\
\text { \& }\end{array}$ & 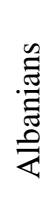 & 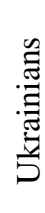 & 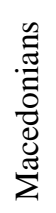 & $\begin{array}{l}\text { 离 } \\
\frac{0}{0} \\
\frac{0}{n}\end{array}$ & 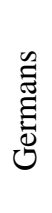 & 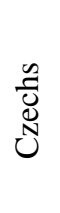 & 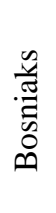 & 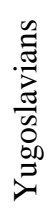 & $\begin{array}{l}\text { 峁 } \\
\text { 苛 }\end{array}$ & 吾 \\
\hline 4 & 1 & 1 & 0 & 1 & 55 & $\overline{0}$ & 0 & 0 & $\overline{0}$ & 0 & $\overline{0}$ & 1 & 0 & 0 & 0 & 0 & 0 & 0 & 63 \\
\hline
\end{tabular}




\begin{tabular}{|c|c|c|c|c|c|c|c|c|c|c|c|c|c|c|c|c|c|c|c|}
\hline \multicolumn{20}{|c|}{ SLOVAK LANGUAGE } \\
\hline $\begin{array}{l}0 \\
\stackrel{0}{0} \\
\tilde{n}\end{array}$ & 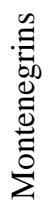 & 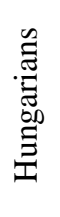 & $\begin{array}{l}\frac{n}{n} \\
\frac{\partial}{n} \\
\frac{0}{n}\end{array}$ & 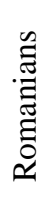 & 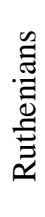 & $\begin{array}{l}\stackrel{0}{\tilde{U}} \\
\stackrel{0}{0}\end{array}$ & 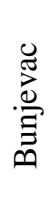 & 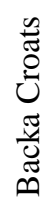 & 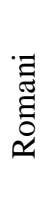 & 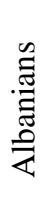 & 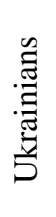 & 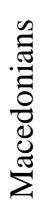 & $\begin{array}{l}\tilde{\Xi} \\
\frac{\tilde{J}}{\tilde{D}} \\
\frac{0}{\tilde{a}}\end{array}$ & 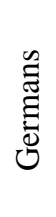 & 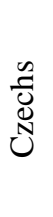 & 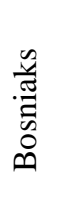 & 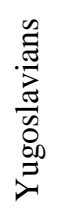 & 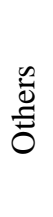 & $\stackrel{\bar{\Xi}}{0}$ \\
\hline 2 & 0 & 0 & 338 & 0 & 1 & 2 & 0 & 0 & 0 & 0 & 0 & 0 & 0 & 0 & 0 & 0 & 1 & 1 & 345 \\
\hline
\end{tabular}

\begin{tabular}{|c|c|c|c|c|c|c|c|c|c|c|c|c|c|c|c|c|c|c|c|}
\hline \multicolumn{20}{|c|}{ CROATIAN LANGUAGE } \\
\hline $\begin{array}{l}0 \\
\stackrel{0}{0} \\
\tilde{D}\end{array}$ & 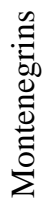 & 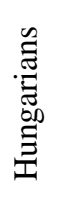 & $\begin{array}{l}\frac{\tilde{u}}{\tilde{\omega}} \\
\frac{\overrightarrow{0}}{\tilde{n}}\end{array}$ & 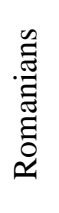 & 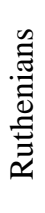 & 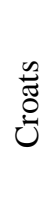 & 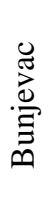 & ש & 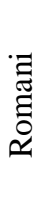 & $\stackrel{2}{a}$ & 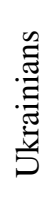 & 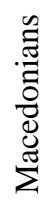 & 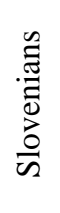 & 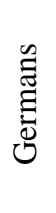 & 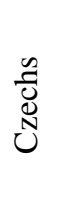 & 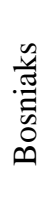 & 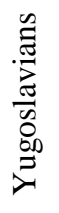 & $\begin{array}{l}\text { 节 } \\
\text { tँ }\end{array}$ & 吾 \\
\hline 2 & 0 & 0 & 0 & 0 & 0 & 59 & 4 & 0 & 0 & 1 & 0 & 0 & 0 & 0 & 0 & 0 & 0 & 3 & 69 \\
\hline
\end{tabular}

76. In the Republic of Serbia there is a possibility to learn German language as a foreign language at primary and secondary schools. German language, as the first foreign language was introduced into the educational system in Serbia already in 1808. Depending on the economic-political circumstances in the country, German language had a different status at educational institutions- from studying it as the first or the second foreign language to exclusion from teaching within the period after the World War II. At present German is taught at primary and secondary schools as the first or the second foreign language. According to the information of the Ministry of Education, about 5\% of pupils is currently studying this language at primary and secondary schools in the Central Serbia. For illustration purposes, the table below contains the data on the number of pupils at primary schools who studied German as a foreign language in the 2007/2008 school year.

\begin{tabular}{|l|c|c|c|}
\hline \multicolumn{1}{|c|}{ G R A D E } & $\begin{array}{c}\text { Total Number of } \\
\text { Pupils }\end{array}$ & \multicolumn{2}{|c|}{ German Language } \\
\hline & & TOTAL & $\%$ \\
\hline $1^{\text {st }}$ GRADE & 52,591 & 586 & 1.11 \\
\hline $2^{\text {nd }}$ GRADE & 50,271 & 824 & 1.64 \\
\hline $3^{\text {rd }}$ GRADE & 51,398 & 901 & 1.75 \\
\hline $4^{\text {th }}$ GRADE & 56,910 & 879 & 1.54 \\
\hline TOTAL & $\mathbf{2 1 1 , 1 7 0}$ & $\mathbf{3 , 1 9 0}$ & $\mathbf{1 . 5 1}$ \\
\hline & & & \\
\hline $5^{\text {th }}$ GRADE & 57,896 & 5,424 & 9.37 \\
\hline $6^{\text {th }}$ GRADE & 58,455 & 3,110 & 5.32 \\
\hline $7^{\text {th }}$ GRADE & 58,310 & 2,728 & 4.68 \\
\hline
\end{tabular}




\begin{tabular}{|l|c|c|c|}
\hline $8^{\text {th }}$ GRADE & 58,416 & 2,316 & 3.96 \\
\hline TOTAL & $\mathbf{2 3 3 , 0 7 7}$ & $\mathbf{1 3 , 5 7 8}$ & $\mathbf{5 . 8 3}$ \\
\hline
\end{tabular}

77. According to the information of the Provincial Secretariat of Education of AP of Vojvodina, at primary schools in the territory of AP of Vojvodina, German is studied as the first and the second foreign language by the following number of pupils:

\begin{tabular}{|c|c|c|c|}
\hline School year & $\begin{array}{c}\text { Number of Local Self- } \\
\text { Governments }\end{array}$ & $\begin{array}{c}\text { NUMBER OF } \\
\text { SCHOOLS }\end{array}$ & Number of Pupils \\
\hline 2006.2007 & 36 & 141 & 25,131 \\
\hline $2007 / 2008$ & 40 & 227 & 33,084 \\
\hline $2008 / 2009$ & 41 & 231 & 42,011 \\
\hline
\end{tabular}

78. The table below contains the data on the number of pupils at secondary schools in the territory of AP of Vojvodina, who selected to study German as a foreign language in the 2009/2010 school year.

\begin{tabular}{|l|c|c|c|}
\hline $\begin{array}{c}\text { Study of German } \\
\text { Language }\end{array}$ & $\begin{array}{c}\text { Number of Pupils in 3 years } \\
\text { of education }\end{array}$ & $\begin{array}{c}\text { Number of pupils in 4 } \\
\text { years of education }\end{array}$ & Total \\
\hline First foreign language & 1,853 & 4,308 & 6,161 \\
\hline Second foreign language & 500 & 9,902 & 10,402 \\
\hline Total & 2,353 & 14,210 & 16,563 \\
\hline
\end{tabular}

\subsubsection{Promotion of the study and research of minority languages at universities}

79. The data on the practice in study and research of minority languages at universities are contained in the Section 3.2 and in the Section 4.1.6. of this Report.

\subsubsection{Promotion of trans-national exchange}

80. As stated in the Section 4.1.9. of the First Periodic Report on the implementation of the Charter, promotion of adequate forms of trans-national exchanges in the fields of social life the Charter addresses, is regulated in the provisions of the Constitution of the Republic of Serbia, laws and the provisions of international treaties governing the protection of national minorities. The Republic of Serbia is a contracting party to several bilateral agreements on protection of national minorities, as well as to several agreements on co-operation in the field of education, culture and other fields, which also contain the provisions of importance for trans-national co-operation in the fields of social life a minority language is used in.

81. Within the period after the first cycle of monitoring of the implementation of the Charter, the activities of inter-governmental mixed commissions were activated again, namely of minority committees with Hungary and Croatia, which had been 
established in accordance with the agreements on protection of the rights of the Serbian national minority in these countries and of the Hungarian, namely of the Croatian national minorities in Serbia. The third meeting of the InterGovernmental Mixed Commission for Minorities with Hungary was held on 21 and 22 May 2009 in Novi Sad and the third meeting of the Inter-Governmental Mixed Committee for Minorities with the Republic of Croatia was held on 14 and 15 October 2009 in Belgrade and Subotica. Both these meetings were held to consider on-going and current issues related to the Serbian minority in Hungary and Croatia, namely to Hungarian and Croatian minorities in Serbia, to examine the fulfilment of obligations resulting from the mentioned agreements, implementation of recommendations adopted at previous meetings and giving of new recommendations to the governments of the contracting parties in respect of the implementation of the agreements. The fourth meeting of the InterGovernmental Mixed Committee for Minorities, monitoring the implementation of the provisions of the Agreement between the Republic of Serbia and the Republic of Croatia on protection of minority rights was held on 17 and 18 June 2010 in Zagreb and in Vukovar, respectively. In addition to consideration of implementation of recommendations adopted at the previous meeting and establishment of the new ones, the current state of affairs in the two minority communities was also discussed. The first meeting of the Inter-Governmental Mixed Commission for Minorities with Romania was held on 23 November 2009 in Bucharest (Romania). The text of the Rules of the Commission was consolidated and signed at this meeting, as well as the text of the Minutes of the first meeting. It was agreed that the degree of fulfilment of obligations undertaken by the states in respect of protection of the rights of minorities shall be analyzed at the next meeting and to adopt concrete recommendations with the aim to improve the fulfilment of such obligations. It is expected that in the forthcoming period the first meeting of the Inter-Governmental Mixed Commission with Macedonia shall be also held.

82. In the middle of 2009, as the legal successor of the State Union of Serbia and Montenegro, the National Assembly of the Republic of Serbia upheld the Agreement between the Ministers of Serbia and Montenegro and the Government of the Republic of Hungary on co-operation in the field of education, science, culture, youth and sports, which was signed on 13 March 2006. It is prescribed in Article 2 of this Agreement that the contracting parties shall take special care of the support to be rendered by the institutions and experts who deal with languages, history, culture and art of the other contracting party, as well as about linguistic and professional education and advancement of interpreters. After this Agreement had entered into force on 5 June 2009, the Ministry of Education and Culture of the Republic of Hungary submitted its draft of the Co-operation Programme in the field of culture between the Ministry of Education and Culture of the Republic of Hungary and the Ministry of Culture of the republic of Serbia on 18 February 2010 for the period 2010 - 2011. The texts of the Programme shall be conformed in the forthcoming period, which are to be signed by the Ministers of Culture of the two countries concerned. The Programme shall define in more 
details all the actions and activities in all fields of culture and the financial conditions for their implementation. In spite of the lack of the relevant programme, co-operation with Hungary is achieved in culture in all fields.

83. Based on the Agreement between the Government of the Federal Republic of Yugoslavia and the Government of the Republic of Macedonia in the field of education, culture and sports, which was signed in 1997 and entered into force in 1998, the Co-operation Programme in the field of culture was signed on 22 July 2009 between the Ministry of Culture of the Republic of Serbia and the Ministry of Culture of the Republic of Macedonia for 2009, 2010 and 2011.The Programme prescribes co-operation in various fields of culture (music, theatre, painting, cultural heritage, archives and libraries, literature and publishing, film, public information means). In the past period several significant actions were performed (the Cultural days of Serbia in Macedonia in November 2009) and the direct co-operation of theatres from the two countries should be stressed in particular.

84. Based on the Agreement between the Government of the Federal Republic of Yugoslavia and the Government of the Republic of Slovakia in the field of education, culture and sports, which was signed in 1996 and entered into force the same year, the Co-operation Programme in the field of culture was signed on 26 February 2010 between the Ministry of Culture of the Republic of Serbia and the Ministry of Culture of the Republic of Slovakia for the period 2010-2013. The Programme prescribes co-operation in various fields of culture. Special attention is paid to participation of music and theatre groups at the international music and theatre festivals that are held in the two countries, direct co-operation between museums and galleries, protection of monuments of culture, co-operation in the field of literature and publishing, co-operation between libraries, co-operation in the field of film.

85. The Co-operation Programme in the field of culture between the Ministry of Culture of the Republic of Serbia and the Ministry of Culture and Tourism of Ukraine for 2009, 2010 and 2011 was signed in Kiev on 7 April 2009. On the grounds of this Programme the Cultural Days of Serbia were implemented in Ukraine in April 2009, and the representatives of the Ukrainian national minority in Serbia also took part at this manifestation.

86. The Agreement between the Government of the Federal Republic of Yugoslavia and the Government of the Republic of Macedonia on co-operation in the field of culture and education was signed in 2002 and entered into force in 2003. In March 2003, the Ministry of Foreign Affairs initiated the procedure for the preparation of the Co-operation Programme in the field of education, culture and sports between the Council of Ministers of Serbia and Montenegro and the Government of the Republic of Croatia for the period 2004-2006. On two occasions the Ministry of Culture submitted its supplements, objections and suggestions in respect of the proposed document. The Croatian party showed no 
interest to continue the programme making. The co-operation with Croatia in the field of modern art is satisfactory, in spite of the fact that no Co-operation Programme in the field of culture had been concluded. After the democratic changes in the Republic of Serbia in 2000, it may be noticed that groups and artists from the two countries visit the countries concerned more frequently, and the largest scope of co-operation was achieved between theatre groups from both the countries concerned.

\subsubsection{Elimination of unfavourable treatment of use of minority languages and adoption of special measures in favour of minority languages}

87. The legal ground for elimination of any unjustified distinction exclusion, restriction or preference relating to the use of a regional or minority language and intended to discourage or endanger the maintenance or development of it is contained in the provisions of the Constitution on equality, as well as in the provisions of laws legally protecting the use and the right to use of minority languages, which was contained in the Section 3.4. of the First Periodic Report on implementation of the Charter. Within the period after the first cycle of monitoring of implementation of the Charter, in 2003 the National Assembly of the Republic of Serbia adopted the Law on Prohibition of Discrimination, thus creating a general anti-discrimination standardized and institutional framework that define in an uniform way the field of anti-discrimination in one place and in a comprehensive way. The Law on Prohibition of Discrimination, as a general law, shall provide general definition of discrimination and affirmative actions; establish the definitions of discrimination against certain categories of persons and in certain cases; prescribe the forms of discrimination; prescribe a special body or authority to co-ordinate actions related to prohibition of discrimination, which shall have different options in relation to the bodies and persons violating prohibition of discrimination; prescribe special civil proceedings for protection against discrimination, establish tortuous liability and prescribe offences for discriminatory behaviour, and it shall also resolve other issues that should render, as a general framework, sufficient institutional guarantees to prevent discrimination. Supervision over its implementation is carried out by the ministry in charge of human and minority rights. The adoption of this Law does not mean any obstacle to adopt in future other special laws in this field because the general anti-discrimination law provides uniform and efficient system guarantees for prevention of discrimination, and adopt possibly other laws and regulations for special fields and for special categories of persons. In this sense, legally established independent and impartial body for protection of equality - the Commissioner for Protection of Equality, has a particular importance for it is the very body that should encourage and ensure future development of legislation in this field. The Commissioner for Protection of Equality receives and examines the complaints because of violations of the provisions of the law and adopts sanctions. The Commissioner has also been granted legal capacity to sue, namely, it has the right to file actions. This independent body should have the role of a coordinator in establishing the future uniform system of prohibition of 
discrimination. Since the budget for 2010 also includes the necessary financial means for the activities of the Commissioner and its professional services, as well as for the exercise of its competences, material assumptions for its activities have been created. On 5 May 2010 the National Assembly of the Republic of Serbia elected the Commissioner for Protection of Equality.

88. The Law on Prohibition of Discrimination prescribes that causing and incitement of inequality, hate and intolerance on the grounds of minority languages are severe forms of discrimination, which results in the initiation of a trial and ordering of sanctions to responsible subjects, according to the seriousness of the form of committed discrimination. Severe forms of discrimination are defined in respect of the position of the offender or in respect of the way discrimination is committed - public position (public authority or in the proceedings before the public authority and the method in which the act of discrimination is committed (through the media). The Law on Protection of Minority Languages included in the wider context prohibitions of discrimination against national minorities and their members on the grounds of national affiliation, ethnic origin, religious beliefs and language. The legal ground of prohibition of discrimination is the principle of equality because discrimination exists if citizens are placed in an unequal position due to some personal characteristic, because of the language in in this case. The Law prescribes that everyone enjoys equal position and equal legal protection, regardless of his/her personal properties.

89. In the Section 4.1.10.2. of the First Periodic Report on the implementation of the Charter, as a special example of adoption of measures in favour of minority languages, which would have the aim to improve equality among those who use the languages concerned and the rest of the population or which take into account their specific conditions, the measures such as the introduction of so-called Romani assistants in the teaching process are mentioned. In the meantime, this measure has become a system measure because the new Law on Fundamentals of Educational and Up-bringing System prescribes the existence of assistants at schools, whose task is to render assistance and additional support to children and pupils, in accordance with their needs, as well as assistance to teachers, child minders and expert associates with the aim to improve their activities with children and pupils who need additional educational support. For the work with pupils of Romani nationality who need additional support and assistance 61 pedagogue assistants are engaged at primary schools in 28 units of local selfgovernment (Aleksinac, Alibunar, Вас̌ка Palanka, Bela Palanka, Belgrade, Beočin, Bor, Bujanovac, Valjevo, Vladičin Han, Vranje, Jagodina, Kikinda, Kostolac, Koceljeva, Kragujevac, Kraljevo, Kruševac, Leskovac, Mol, Niš, Novi Sad, Odžaci, Prokuplje, Subotica, Surdulica, Čurug and Šabac). It has been planned that another 128 pedagogue assistants at 80 primary schools and 48 preschool institutions in the territory of the Republic of Serbia shall be engaged as from the next school year. 


\subsubsection{Promotion of mutual understanding between all language groups}

90. Within the period after the first cycle of monitoring of the implementation of the Charter, laws encouraging the spirit of tolerance and inter-cultural dialogue (see Section 2.1.1.) between all language groups were adopted, which contribute to the improvement of mutual respect, understanding and co-operation between all people living in the territory of the Republic of Serbia, regardless of their ethnic, cultural, linguistic or religious identity. The activities for the improvement of mutual understanding between all language groups are contained in the Section 3.3.4. of this Report.

\subsubsection{Advisory bodies}

91. National councils of national minorities, according to the constitutional and legal solutions, are special bodies that are also competent to advise the authorities in respect of minority languages. The competences of national councils of national minorities are contained in the Section 2.2.2. of this Report. The presidents of the national councils of national minorities are the members of the Council of the Republic of Serbia for National Minorities, which, inter alia, takes care of preservation, improvement and protection of linguistic and cultural specificies of the members of national minorities in the Republic of Serbia (see Section 2.1.1.)

\subsection{Information on the implementation of the Charter for Minority Languages for which obligations from Part III of the Charter are not taken over}

92. In the First Periodic Report on the Implementation of the Charter, the republic of Serbia precisely stated that the following languages are minority languages in the Republic of Serbia: Albanian, Bosniak, Bulgarian, Vlach, Hungarian, Macedonian, German, Romani, Romanian, Ruthenian, Slovak, Ukrainian, Croatian and Czech, as well as that Bunjevac will be treated as a minority language as long as the standardization is not a condition for the implementation of certain measures. In view of the fact that the Republic of Serbia took over the obligations from Part III of the Charter concerning Albanian, Bosniak, Bulgarian, Hungarian, Romani, Romanian, Ruthenian, Slovak, Ukrainian and Croatian languages, it is necessary to examine the data on the state of other minority languages, including Bunjevac, too, which it decided to treat as a minority language of Part II of the Charter after consultations with the speakers of this language.

\subsubsection{Bunjevac speech}

93. Bunjevac is not officially used in any unit of local self-government because it has not been standardized yet.

94. According to the information obtained from the National Council of the Bunjevac national minority, the standardization process has been in progress, and its more 
serious stage started in 2009 by the implementation of the project for the preparation of grammar of Bunjevac language, which also included, in addition to the National Council, the Faculty of Philosophy in Novi sad and the Balkan Institute of the Serbian Academy of Science and Art from Belgrade. After the field researches of Bunjevac speech in Subotica, Sombor and in the surroundings of these two towns, which are considered to be cultural and historic centres by the Bunjevac people, a lot of documentation was collected. It is planned that this project will be completed in 2012 and the grammar and spelling rules of Bunjevac will follow, and this whole process should be completed by ratification of Bunjevac language as a standard language of the Bunjevac national minority.

95. Although Bunjevac language is not standardized, the Republic of Serbia encourages or facilitates its use by undertaking measures in certain fields where standardization of a language is not a condition of its use.

96. There is no pre-school education in Bunjevac speech at any pre-school institution or school in the Republic of Serbia. According to the information of the Provincial Secretariat of Education of AP of Vojvodina, in the territory of AP of Vojvodina, in two local self-governments, in Subotica and Sombor, there are 87 children in total of pre-school age of the Bunjevac nationality. Out of this number, for 83 children pre-school education is arranged in Serbian language, for 2 children in Croatian language and for 2 children it is arranged bilingually, in Serbian and Hungarian languages. There is no comprehensive teaching in Bunjevac speech at primary and secondary schools. At primary schools in Subotica and since 2009/2010 school year at one primary school in Sombor Bunjevac speech with elements of national culture is taught as a school subject. The Table below shows the number of pupils studying this subject.

\begin{tabular}{|l|l|l|c|}
\hline $\begin{array}{l}\text { School } \\
\text { Year }\end{array}$ & $\begin{array}{l}\text { Number of Local } \\
\text { Self-Governments }\end{array}$ & $\begin{array}{l}\text { NUMBER OF } \\
\text { SCHOOLS }\end{array}$ & $\begin{array}{l}\text { Number of } \\
\text { Pupils }\end{array}$ \\
\hline $2007 / 2008)$ & 1 & 9 & 81 \\
\hline $2008 / 2009$ & 1 & 10 & 138 \\
\hline $2009 / 2010$ & 2 & 12 & 171 \\
\hline
\end{tabular}

97. The Table below shows the number of pupils who are the members of the Bunjevac national minority who attend primary schools in the territory of AP of Vojvodina.

\begin{tabular}{|l|l|l|l|}
\hline \multirow{2}{*}{ Level of Education } & \multicolumn{3}{|c|}{ School Year } \\
\cline { 2 - 4 } & $\mathbf{2 0 0 6 / 2 0 0 7}$ & $\mathbf{2 0 0 7 / 2 0 0 8}$ & $\mathbf{2 0 0 8 / 2 0 0 9}$ \\
\hline Primary education & 926 & 908 & 933 \\
\hline
\end{tabular}

98. According to the information of the Provincial Secretariat of Education of AP of Vojvodina, there is no teaching of Bunjevac language with elements of national culture in the 2009/2010 school year at secondary schools, since no pupils expressed such wishes. The Table below shows the number of pupils who are the 
members of the Bunjevac national minority who attend secondary schools in the territory of AP of Vojvodina.

\begin{tabular}{|l|l|l|l|}
\hline \multirow{2}{*}{ Level of Education } & \multicolumn{3}{|c|}{ School Year } \\
\cline { 2 - 4 } & $\mathbf{2 0 0 6 / 2 0 0 7}$ & $\mathbf{2 0 0 7 / 2 0 0 8}$ & $\mathbf{2 0 0 8 / 2 0 0 9}$ \\
\hline Secondary education & 402 & 344 & 403 \\
\hline
\end{tabular}

99. In the sphere of public information in the Republic of Serbia Bunjevac speech is represented in radio programme. In addition to programme broadcasting within the Public Broadcasting Agency of Vojvodina, on the Novi Sad Radio, weekly programmes in Bunjevac of half an hour are broadcast on the Trend Radio from Вас̌ка Topola, the Radio Subotica and the Radio Sombor. At the tender for cofinancing of projects/programmes in the field of public information in minority languages, the Ministry of Culture - Media Sector awarded 257,000.00 dinars in 2007 for the Bunjevačka rič radio programme. The National Council of the Bunjevac national minority is the founder of the Bunjevački informativni centar newspaper publishing institution in Subotica, which publishes the Bunjevacke novine information-political monthly of the Bunjevac national minority and the Tandrčak children's newspapers, which is written in štokavian ikavian dialect, namely speech, before the language is standardized. The Provincial Secretariat of Information of AP of Vojvodina financially supports publishing of these printed media, and the data on subsidies are shown in the Table below.

\begin{tabular}{|l|r|}
\hline \multicolumn{1}{|c|}{ Paper } & \multicolumn{1}{c|}{ Subsidy } \\
\hline The Bunjevačke novine & $14,634,000.00$ \\
\hline The Tandrčak & $4,549,000.00$ \\
\hline
\end{tabular}

100. In 2008 the Ministry of Culture also co-financed periodical publications in Bunjevac - the Bunjevački kalendar za 2009 (almanac) with 150,000.00 dinars. The Bunjevački informativni centar is the main publisher of books in Bunjevac. In the course of 2008 and 2009 it published 5 books, of which one in co-operation with the Matica srpska. Publishing of books in Bunjevac is co-financed by the funds from the republic and provincial budgets on tender basis. The tables below show examples of such co-financing:

Funds awarded by the Ministry of Culture for projects/programmes whose quality contributes to development and presentation of art and culture of national minorities in the field of publishing

\begin{tabular}{|l|l|r|}
\hline \multicolumn{1}{|c|}{ Beneficiary } & \multicolumn{1}{|c|}{ Project } & Granted funds \\
\hline The Bunjevačka Matica,Subotica & Dida,pripovidaj mi & $80,000.00$ \\
\hline $\begin{array}{l}\text { The Bunjevac Information Centre, } \\
\text { Subotica }\end{array}$ & $\begin{array}{l}\text { The Tandrčak } i \text { njegovo blago } 2 \\
\text { children's book }\end{array}$ & $150,000.00$ \\
\hline
\end{tabular}

Funds awarded by the Provincial Secretariat of Culture of AP of Vojvodina for publishing of books in Bunjevac 


\begin{tabular}{|l|l|r|}
\hline \multicolumn{1}{|c|}{ Publisher } & \multicolumn{1}{|c|}{ Author and Book's Title } & Granted Funds \\
\hline $\begin{array}{l}\text { The Matica Srpska, } \\
\text { Novi Sad }\end{array}$ & Dragoljub Petrović, Rečnik Bačkih Bunjevaca & $40,000.00$ \\
\hline The Bunjevačka & Group of authors, Lipota naših riči & $35,000.00$ \\
Matica, Subotica & Tamara Baić, Muzička baština Bunjevaca & $50,000.00$ \\
\hline The Bunjevac & Gabrijela Diklić, Snaš Kata na mrginju & $50,000.00$ \\
Information Centre, & Marija Horvat, Promaja kroz pendžere rimena & $34,000.00$ \\
Subotica & Saša Marković, Politička istorija Bunjevaca 1918-1941 & $20,000.00$ \\
\hline
\end{tabular}

101. For fostering of language and culture they represent, cultural manifestations of speakers of such languages are of importance. Cultural manifestations related to Bunjevac are co-financed on tender basis from the republic and provincial budgets. The tables below show examples of such co-financing:

Funds awarded by the Ministry of Culture for projects/programmes whose quality contributes to development and presentation of art and culture of national minorities to hold cultural manifestations related to Bunjevac

\begin{tabular}{|l|l|r|}
\hline \multicolumn{1}{|c|}{ Beneficiary } & \multicolumn{1}{|c|}{ Project } & Granted Funds \\
\hline The Bunjevačko Kolo, Sombor & Dužionica 2007, 2008 & $270,000.00$ \\
\hline The Bunjevka, Subotica & $\begin{array}{l}9^{\text {th }}, 10^{\text {th }} \text { and } 11^{\text {th }} \text { Festival of Bunjevac } \\
\text { Traditional Works }\end{array}$ & $310,000.00$ \\
\hline The Bunjevačka Matica, Subotica & $\begin{array}{l}\text { Bunjevačka lipa rič, } 1^{\text {st }} \text { and } 2^{\text {nd }} \text { Festival } \\
\text { of Literature Works of Young People in } \\
\text { Bunjevac }\end{array}$ & $100,000.00$ \\
\hline
\end{tabular}

Funds awarded by the Provincial Secretariat of Culture of AP of Vojvodina to hold cultural manifestations related to Bunjevac

\begin{tabular}{|l|l|l|c|}
\hline \multicolumn{1}{|c|}{ Place } & \multicolumn{1}{|c|}{ Beneficiary } & \multicolumn{1}{|c|}{ Purpose } & Amount \\
\hline Sombor & $\begin{array}{l}\text { The Bunjevačko Kolo, } \\
\text { Association of Citizens }\end{array}$ & Dužionica 2007, 2008 & $250,000.00$ \\
\hline Subotica & The Bunjevka & $\begin{array}{l}9^{\text {th }}, 10^{\text {th }} \text { and } 11^{\text {th }} \text { Festival of } \\
\text { Bunjevac Traditional Works }\end{array}$ & $245,000.00$ \\
\hline Subotica & The Bunjevačka Matica & Tuesday Evenings & $45,000.00$ \\
\hline
\end{tabular}

\subsubsection{Vlach language}

102. Vlach is not officially used in any unit of local self-government because it has not been standardized yet. Although there is no agreement among the speakers of this language about the standardization of the language, according to the information obtained from the Zajednica Vlaha P. Matejić, an association of citizens, in 2008 this association made an initiative to standardize Vlach script and formed the initiative committee and informed the authorities of the Republic of Serbia accordingly. 
103. Since Vlach language is not standardized, there is no teaching of the members of the Vlach national minority at any level of education. Vlach language with elements of national culture is not taught as the school subject at primary and secondary schools. The National Council of the Vlach National Minority, as the institution in charge of cultural autonomy and the holder of the initiative to provide education in mother tongue, established by its statute Romanian language to be mother tongue of this national minority and addressed a request to the Ministry of Education to introduce Romanian language with elements of national culture as the school subject, although, according to the allegations of the very National Council, over $98 \%$ of speakers of Vlach language do not either understand or speak Romanian.

104. In spite of the fact that Vlach language is not standardized, there are certain measures by the state encouraging or facilitating the use of Vlach language in the field of public information and culture. The Ministry of Culture granted funds for the projects in Vlach language within the tenders for co-financing of projects /programmes in the field of public information in minority languages, as shown in the Table below.

\begin{tabular}{|c|c|c|}
\hline Project Applicant & Project Title & Granted Funds \\
\hline $\begin{array}{l}\text { RTV Zaječar, } \\
\text { Zaječar }\end{array}$ & TV Journal in Vlach language & $357,000.00$ \\
\hline $\begin{array}{l}\text { Radio Magnum, } \\
\text { Zaječar }\end{array}$ & $\begin{array}{l}\text { Da se ne zaboravi - informative } \\
\text { programme in Vlach and series of } \\
\text { programmes on life and customs of } \\
\text { Vlach }\end{array}$ & $480,000.00$ \\
\hline $\begin{array}{l}\text { 3A Media } \\
\text { Zaječar }\end{array}$ & $\begin{array}{l}\text { Series of TV programmes in Vlach and } \\
\text { Romanian languages }\end{array}$ & $641,250.00$ \\
\hline $\begin{array}{l}\text { Radio Djerdap, } \\
\text { Kladovo }\end{array}$ & Buna zia prieteni - aici radio Djerdap & $409,000.00$ \\
\hline $\begin{array}{l}\text { RTV Kladovo, } \\
\text { Kladovo }\end{array}$ & Život i običaji Vlaha u Ključu & $742,600.00$ \\
\hline $\begin{array}{l}\text { STV Negotin, } \\
\text { Negotin }\end{array}$ & News in the Vlach language & $387,600.00$ \\
\hline $\begin{array}{l}\text { RTV Krajina, } \\
\text { Negotin }\end{array}$ & $\begin{array}{l}\text { Programmes in Vlach - documentary } \\
\text { stories } \\
\text { Informative programme in Vlach } \\
\text { language }\end{array}$ & $\begin{array}{l}400,000.00 \\
276,000.00\end{array}$ \\
\hline
\end{tabular}

105. The Ministry of Culture also co-financed three projects whose quality contributes to development and presentation of art and culture of speakers of Vlach language. On tender basis, the funds were awarded to co-finance the projects shown in the Table below.

\begin{tabular}{|c|c|c|}
\hline Beneficiary & Project & Granted Funds \\
\hline $\begin{array}{l}\text { Paun es Durlić } \\
\text { Balkankult fondacija, Belgrade }\end{array}$ & $\begin{array}{l}\text { Poslednji orfeji Balkana, } \\
\text { Collection, processing and bilingual } \\
\text { publishing of Vlach oral and music } \\
\text { works }\end{array}$ & $160,000.00$ \\
\hline
\end{tabular}




\begin{tabular}{|l|l|r|}
\hline $\begin{array}{l}\text { The National Council of the Vlach } \\
\text { National Minority, Bor }\end{array}$ & Muma Paduri & $340,000.00$ \\
\hline Izvor Cultural Art Club, Laznica & $\begin{array}{l}\text { Priveg i rajska sreća - sačuvano od } \\
\text { zaborava }\end{array}$ & $80,000.00$ \\
\hline
\end{tabular}

\subsubsection{Macedonian language}

106. Macedonian language is not officially used in any unit of local self-government because in the territory of the Republic of Serbia there is no unit of local selfgovernment where the number of the members of the Macedonian national minority reaches $15 \%$ of the total number of population according to the last census, which represents a condition for compulsory introduction into equal official use of a minority language and script, pursuant to the Law on Protection of Rights and Freedoms of National Minorities (Article 11 paragraph 2), namely pursuant to the amended and supplemented Law on Official Use of Language and Script (Article 11 paragraph 2). However, on the grounds of the provisions of the decision on more precise resolution of certain issues of official use of language and script of national minorities in the territory of AP of Vojvodina, which prescribe that the language and script of a national minority shall be introduced into the official use in the settlement or local community in the unit of local selfgovernment where the language and script concerned are not officially used in the entire territory, if the percentage of the members of certain national minority, according to the results of the last census reaches $25 \%$ of the total number of inhabitants of the settlement or local community concerned, Macedonian language was introduced into official use in Pančevo, in the territory of Jabuka and Plandište settlements, in the territory of Dužine settlement. Although it is a certain progress for the Vardar association of Macedonians from the South Banat District from Pančevo, it has the standpoint that on the occasion of adoption of decisions on introduction of the language concerned into the official use, local self-government were explicitly lead by the numerical quantitative principle (legal threshold of 25\%), ,not taking into account the needs of Macedonian community from neighbouring villages and at the level of the entire municipality, to enjoy, foster and develop the right to use mother tongue in public life. This has the consequence that only $38.91 \%$ of the members of the Macedonian community in Pančevo enjoy the right of use Macedonian language and script officially, while the major part (61.8\%), in the same town, has nothing of this benefit".

107. In the educational system of the Republic of Serbia, at pre-school level, at primary and secondary schools there is no teaching in Macedonian language arranged. Study of Macedonian language with elements of national culture as the school subject at primary and secondary schools is not arranged, because there were no requests by any pupils to do so according to the information of the Provincial Secretariat of Education. The number of pupils of Macedonian nationality attending primary and secondary schools in the territory of AP of Vojvodina is shown in the Table below: 


\begin{tabular}{|l|l|l|l|}
\hline \multirow{2}{*}{ Level of Education } & \multicolumn{3}{|c|}{ School Year } \\
\cline { 2 - 4 } & $\mathbf{2 0 0 6 / 2 0 0 7}$ & $\mathbf{2 0 0 7 / 2 0 0 8}$ & $\mathbf{2 0 0 8 / 2 0 0 9}$ \\
\hline Primary education & 696 & 755 & 682 \\
\hline Secondary education & 301 & 291 & 308 \\
\hline
\end{tabular}

108. The National Council of the Macedonian National Minority has prepared the curricula for Macedonian language with elements of national culture to be taught from the first to the fourth grade of primary school. After the provision of the positive opinion from the Ministry of Education, teaching of Macedonian language with elements of national culture will be introduced into primary schools in settlements where a larger number of the members of the Macedonian national minority live (Jabuka, Kačarevo, Plandište, Hajdučica, Gudurica), if the pupils express interest to study this subject. Macedonian language is studied at three faculties in the Republic of Serbia. At the Faculty of Philology in Belgrade, Department of Serbian Language and South Slav Languages, Macedonian is studied as an optional subject. Study is arranged at the level of foreign-language instructorship and takes place at the third year within two semesters. 10 students enrolled to study Macedonian language in 2009/2010 school year. At the Faculty of Philosophy in Novi Sad, Macedonian language is studied as an optional subject at the Department of Serbian Language, Department of Serbian Literature and Department of Russian Language and Literature. The study of this subject takes place at the fourth year and lasts for two semesters. 57 students enrolled to study Macedonian language at all three departments in the 2009/2010 school year. At the Faculty of Philosophy in Niš, Macedonian is studied as an optional language within the Study programme of Serbian Language and Literature. The study of this subject takes place at the first year and lasts for two semesters. 48 students enrolled to study Macedonian language in the 2009/2010 school year.

109. In the sphere of public information in the Republic of Serbia Macedonian language is represented in electronic and printed media. In addition to half an hour programmes broadcast once a week with the Public Broadcasting Agency of Vojvodina, the Novi Sad Radio and the RTV Vojvodina, Pančevo TV broadcasts half an hour programme in Macedonian language once a week. The National Council of the Macedonian National Minority is the founder of the Macedonian Information and Publishing Centre, which is the publisher of the Makedonska videlina, also including the Sunica (Rainbow) children's newspaper. Subsidies of the Provincial Secretariat of Information of AP of Vojvodina for this magazine amounted to 12,490,000.00 dinars. In 2008 the Ministry of Culture also cofinanced periodical publications in the field of art and culture in Macedonian language. The Videlo, magazine for literature, art and culture was co-financed with 50,000.00 dinars, which is published by the Macedonian Information and Cultural Centre. This Centre is also the main publisher of books in Macedonian language, which, in addition to books in Macedonian language, also publishes translations of the books written by Macedonian authors into Serbian language 
and translations of the books written by Serbian authors into Macedonian language. Five books were published within the previous two years.

110. For fostering of language and culture they represent, cultural manifestations of speakers of such languages are of importance. Cultural manifestations related to Macedonian language are co-financed on tender basis from the republic and provincial budgets. The tables below show examples of such co-financing:

Funds awarded by the Ministry of Culture for projects/programmes whose quality contributes to development and presentation of art and culture of national minorities to hold cultural manifestations related to Macedonian language

\begin{tabular}{|l|l|c|}
\hline \multicolumn{1}{|c|}{ Beneficiary } & \multicolumn{1}{|c|}{ Project } & Granted Funds \\
\hline $\begin{array}{l}\text { The Kiril } \text { i Metodije, Association of } \\
\text { Citizens of Macedonian National } \\
\begin{array}{l}\text { Minority in the South Bačka District, } \\
\text { Novi Sad }\end{array}\end{array}$ & $\begin{array}{l}\text { Days of Macedonian Culture in Novi } \\
\text { Sad }\end{array}$ & $200,000.00$ \\
\hline $\begin{array}{l}\text { The National Council of the } \\
\begin{array}{l}\text { Macedonian National Minority, } \\
\text { Pančevo }\end{array}\end{array}$ & $\begin{array}{l}\text { Денови на македонското творештво } \\
\text { во Република Србија - Кон себе бо } \\
\text { поход/Sеві и роһоде }\end{array}$ & $150,000.00$ \\
\hline $\begin{array}{l}\text { Macedonian Information and } \\
\text { Publishing Centre, Pančevo }\end{array}$ & $\begin{array}{l}\text { Second Days of Macedonian Culture in } \\
\text { Serbia - Себи у походе }\end{array}$ & $450,000.00$ \\
\hline
\end{tabular}

Funds awarded by the Provincial Secretariat of Culture of AP of Vojvodina to hold cultural manifestations related to Macedonian language

\begin{tabular}{|l|l|l|c|}
\hline \multicolumn{1}{|c|}{ Place } & \multicolumn{1}{|c|}{ Beneficiary } & \multicolumn{1}{c|}{ Purpose } & Amount \\
\hline Jabuka & The Kosta Racin, Culture Club & $\begin{array}{l}\text { 4th, } 5^{\text {th }} \text { and 6th Theatre Festival for } \\
\text { Children }\end{array}$ & $80,000.00$ \\
\hline Pančevo & $\begin{array}{l}\text { The National Council of the } \\
\text { Macedonian National Minority }\end{array}$ & $\begin{array}{l}\text { Days of Macedonian Tradition }- \text { Sebi } \\
\text { upohode }\end{array}$ & $105,000.00$ \\
\hline
\end{tabular}

\subsubsection{German language}

111. German language is not officially used in any unit of local self-government because it does not meet legal requirements for compulsory introduction into equal official use for in the territory of the Republic of Serbia there is no unit of local self-government, namely in the territory of AP of Vojvodina there is no settlement or local community where the number of the members of the German national minority reaches $15 \%$, namely $25 \%$ of the total number of inhabitants of the unit of local self-government concerned, namely of the settlement or local community.

112. For children of pre-school age at a pre-school institution in Subotica bilingual teaching is arranged in Serbian and German languages. 


\begin{tabular}{|l|l|l|l|l|}
\hline School Year & $\begin{array}{l}\text { Number of Local Self- } \\
\text { Governments }\end{array}$ & $\begin{array}{l}\text { Number of Pre-School } \\
\text { Institutions }\end{array}$ & $\begin{array}{l}\text { Number } \\
\text { of } \\
\text { Groups }\end{array}$ & $\begin{array}{l}\text { Number } \\
\text { of } \\
\text { Children }\end{array}$ \\
\hline $2007 / 2008$ & 1 & 1 & 1 & 22 \\
\hline $2008 / 2009$ & 1 & 1 & 2 & 43 \\
\hline $2009 / 2010$ & 1 & 1 & 2 & 50 \\
\hline
\end{tabular}

113. Teaching in German and Hungarian languages is carried out at a pre-school institution in Subotica.

\begin{tabular}{|l|l|l|l|l|}
\hline School Year & $\begin{array}{l}\text { Number of Local Self- } \\
\text { Governments }\end{array}$ & $\begin{array}{l}\text { Number of Pre-School } \\
\text { Institutions }\end{array}$ & $\begin{array}{l}\text { Number } \\
\text { of } \\
\text { Groups }\end{array}$ & $\begin{array}{l}\text { Number } \\
\text { of } \\
\text { Children }\end{array}$ \\
\hline $2007 / 2008$ & 1 & 1 & 1 & 18 \\
\hline $2008 / 2009$ & 1 & 1 & 1 & 22 \\
\hline $2009 / 2010$ & 1 & 1 & 1 & 23 \\
\hline
\end{tabular}

114. In the educational system the Republic of Serbia at primary and secondary schools there is no teaching in German language or study of German language with elements of national culture as the school subject. Study of German language with elements of national culture at primary and secondary schools is not arranged since the pupils did not express wishes to do so. Nevertheless, thanks to the fact that German language is one of the world languages, it is present as one of foreign languages at schools and faculties in Serbia. It is a good opportunity for children of the German national minority to learn and improve their mother tongue at school during classes of German language as a foreign language subject. The number of pupils of the German nationality attending primary and secondary schools in the territory of AP of Vojvodina is contained in the Table below:

\begin{tabular}{|l|l|l|l|}
\hline \multirow{2}{*}{ Level of Education } & \multicolumn{3}{|c|}{ School Year } \\
\cline { 2 - 4 } & $\mathbf{2 0 0 6 / 2 0 0 7}$ & $\mathbf{2 0 0 7 / 2 0 0 8}$ & $\mathbf{2 0 0 8 / 2 0 0 9}$ \\
\hline Primary & 111 & 90 & 99 \\
\hline Secondary & 63 & 58 & 54 \\
\hline
\end{tabular}

115. In the Republic of Serbia, German language and literature are studied at the Faculty of Philology in Belgrade, Department of German Language and Literature, the Faculty of Philosophy in Novi Sad, Department of German Language and Literature and at the Faculty of Philology in Kragujevac, Department of German Studies, Section of German Language and Literature. The Table below contains the data about the number of students studying German language and literature at the above mentioned university institutions.

\begin{tabular}{|l|c|c|c|}
\hline School Year & $\begin{array}{l}\text { Faculty of Philology in } \\
\text { Belgrade }\end{array}$ & $\begin{array}{l}\text { Faculty of Philosophy in } \\
\text { Novi Sad }\end{array}$ & $\begin{array}{l}\text { Faculty of Philology in in } \\
\text { Kragujevac }\end{array}$ \\
\hline $2007 / 2008$ & 384 & 231 & 27 \\
\hline $2008 / 2009$ & 375 & 254 & 30 \\
\hline $2009 / 2010$ & 306 & 248 & 30 \\
\hline
\end{tabular}


116. In the sphere of public information in the Republic of Serbia, German language is represented in the programme of Radio Subotica, with 0.5 hours weekly, and the programme on Radio Odžaci is also being prepared, which shall be broadcasted weekly for up to 2 hours. Until March 2010, TV Panonija from Novi Sad also broadcasted supplements in German language within the weekly programme of Multietnik in co-operation with the National Council of the German National Minority. All supplements within this programme were broadcasted in minority languages with dubbing in Serbian language, which contributes to learning of the majority population about minority languages and cultures thy represent.

117. The cultural days of the German national minority were held for the first time in June 2008 in Novi Sad and then in October the same year in Subotica. This manifestation was supported by the Ministry of Culture with 200,000.00 dinars, based on the tender for co-financing of projects/programmes whose quality contributes to development and presentation of art and culture of national minorities. On tender basis, the Provincial Secretariat of Culture of AP of Vojvodina supported the following cultural manifestations related to German language:

\begin{tabular}{|l|l|l|r|}
\hline \multicolumn{1}{|c|}{ Place } & \multicolumn{1}{c|}{ Beneficiary } & \multicolumn{1}{c|}{ Purpose } & Amount \\
\hline $\begin{array}{l}\text { Sremski } \\
\text { Karlovci }\end{array}$ & $\begin{array}{l}\text { The Karlovic, German } \\
\text { Association for Good } \\
\text { Neighbourhood Relations }\end{array}$ & Gathering of Publicists & $44,000.00$ \\
$\begin{array}{l}\text { Sremska } \\
\text { Mitrovica }\end{array}$ & Gete, German Cultural Centre & Fostering of tradition and culture & $20,000.00$ \\
\hline
\end{tabular}

\subsubsection{Czech language}

118. In addition to Serbian language and Cyrillic script, Hungarian, Romanian and Czech languages and scripts are officially used in the territory of Bela Crkva. Within the last three years, in the territory of the municipality of Bela Crkva no certificate from the registry books was issued in Serbian-Czech form and no administrative proceedings were held in Czech language because no application was submitted in this respect. It is similar in respect of the use of Czech language at courts. Although necessary legal conditions to accomplish the right to use of Czech language are fulfilled, this right is not accomplished in practice in full because there are no requests by the holders of such right. The Matica Češka from Bela Crkva stresses that ,the members of the Czech national community are not in the position to use mother tongue in curt and administrative proceedings, primarily because of the lack of personnel to perform those jobs".

119. At primary and secondary schools in the educational system of the Republic of Serbia there is no entire teaching in Czech and there is no teaching of Czech language with elements of national culture. The curricula for 2007/2008 school 
year provided introduction of the second foreign language as an optional subject, but the Matica Češka stressed that ,the members of this national minority could not win that Czech language is equal with other languages in official use in primary education", and it expects that the things in respect of education in minority languages, as well as in other fields, will be improved and the requests by the speakers of Czech language be strengthened by the election of the National Council of the Czech National Minority. The number of pupils of the Czech nationality attending primary and secondary schools in the territory of AP of Vojvodina is contained in the Table below:

\begin{tabular}{|l|l|l|l|}
\hline \multirow{2}{*}{ Level of Education } & \multicolumn{3}{|c|}{ School Year } \\
\cline { 2 - 4 } & $\mathbf{2 0 0 6 / 2 0 0 7}$ & $\mathbf{2 0 0 7 / 2 0 0 8}$ & $\mathbf{2 0 0 8 / 2 0 0 9}$ \\
\hline Primary & 133 & 120 & 104 \\
\hline Secondary & 38 & 46 & 51 \\
\hline
\end{tabular}

120. In the Republic of Serbia Czech language and literature are studied at the Faculty of Philology in Belgrade, Department of Czech Language and Literature. The Table below shows the number of students studying this language.

\begin{tabular}{|l|l|l|}
\hline School Year & $\begin{array}{l}\text { Number of Enrolled } \\
\text { Students at First Year }\end{array}$ & $\begin{array}{l}\text { Total Number of } \\
\text { Students in All } \\
\text { Four Years }\end{array}$ \\
\hline $2007 / 2008$ & 24 & 82 \\
\hline $2008 / 2009$ & 23 & 82 \\
\hline $2009 / 2010$ & 15 & 55 \\
\hline
\end{tabular}

121. In the sphere of public information, Czech is only represented on Radio Bela Crkva, with one hour programme weekly. The Ministry of Culture - Media Sector, on tender basis for co-financing of projects/programmes in the field of public information in minority languages, awarded the funds for projects in Czech language as shown in the Table below.

\begin{tabular}{|l|l|r|}
\hline Project Applicant & Project Title & Granted Funds \\
\hline Lui Studio- Radio sunce, Bela Crkva & $\begin{array}{l}\text { Initiation of Programmes in Czech } \\
\text { Language for Young People }\end{array}$ & $120,000.00$ \\
\hline The BC info, Bela Crkva & $\begin{array}{l}\text { Preservation of Czech Cultural } \\
\text { Heritage in the Municipality of Bela } \\
\text { Crkva }\end{array}$ & $253,346.00$ \\
\hline
\end{tabular}

122. In order to promote and preserve Czech language and culture it represents, cultural manifestations on tender basis from the republic and provincial budgets were also co-financed. Examples of such financing are shown in the Table below:

Funds awarded by the Ministry of Culture for projects/programmes whose quality contributes to development and presentation of art and culture of national minorities to hold cultural manifestations related to Czech language 


\begin{tabular}{|l|l|r|}
\hline \multicolumn{1}{|c|}{ Beneficiary } & \multicolumn{1}{|c|}{ Project } & Granted Funds \\
\hline The Matica Češka, Bela Crkva & $\begin{array}{l}\text { Presentation of monography - } \\
\text { Kolonizacija Čeha u Banatu }\end{array}$ & $50,000.00$ \\
\hline $\begin{array}{l}\text { Radio Sunce - Glas južnog Banata, } \\
\text { Bela Crkva }\end{array}$ & Pričam ti priču & $100,000.00$ \\
\hline Čška beseda, Kruščica & Folklore Festival of Czechia in Serbia & $50,000.00$ \\
\hline
\end{tabular}

Funds awarded by the Provincial Secretariat of Culture of AP of Vojvodina to hold cultural manifestations related to Czech language

\begin{tabular}{|l|l|l|r|}
\hline \multicolumn{1}{|c|}{ Place } & \multicolumn{1}{|c|}{ Beneficiary } & \multicolumn{1}{c|}{ Намена } & Amount \\
\hline Bela Crkva & KPU Česi Južnog Banata & Days of Czech Culture & $128,000.00$ \\
\hline Bela Crkva & $\begin{array}{l}\text { The Dositej Obradović School } \\
\text { Plus }\end{array}$ & $\begin{array}{l}\text { Traditional Works of Czechs in the } \\
\text { South Banat }\end{array}$ & $35,000.00$ \\
\hline
\end{tabular}

\subsection{Activities for the implementation of box-recommendation of the Committee of Experts related to Article 7 of the Charter}

123. In the Report on the Implementation of the Charter in the first reporting cycle, the Committee of Experts established five box-recommendations related to Article 7 of the Charter. The following paragraphs contain the information on the activities undertaken by the state for their implementation.

\subsubsection{Information on the practical use of Czech language by the administrative authorities and at the Municipal Court of Bela Crkva}

The Committee of Experts encourages the Serbian authorities to take measures to facilitate the practical use of Czech by the administrative authorities and the municipal court of Bela Crkva.

124. The Statute of the municipality of Bela Crkva establishes that Czech language and script are officially used in the territory of the municipality. The official use of language and script of national minorities implies in particular: use of minority languages in administrative and court proceedings and conduct of administrative and court proceedings in minority languages, use of minority language in communications of bodies having public powers with citizens; issuance of public documents and keeping of official records and collections of personal data in minority languages and acceptance of such documents in minority languages as valid, use of language in election lists and election materials, use of language in the activities of representation bodies. In addition, the employees of the body issuing public documents are obliged to notify to the member of national minority his/her right to request that public document is issued in two languages - in Serbian and in minority language and script, in the form published in two languages. Certificates of education, if teaching was carried out in minority language, other public documents, as well as other documents of interest for the accomplishment of the rights of citizens prescribed by law and other regulations, 
which are issued based on records, at the request of members of national minorities, are also issued in his/her language. The forms of public documents, as well as the forms of records for the requirements of the area where minority languages are officially used, are printed in two languages, in Serbian and in minority language officially used. A member of the national minority has the right to provide oral, namely written reply in the language he/she referred to the body. Therefore, the introduction of Czech language and script into the official use in the territory of Bela Crkva, provided assumptions that citizens may use their rights resulting from it, but so far there has been interest for the concrete accomplishment of that established right by the citizens of the municipality of Bela Crkva. At the municipal administration and related local offices there was supervision related to the official use of language and script, and accordingly, in the places where irregularities were noticed, orders were issued to eliminate them. The Government of AP of Vojvodina considered in June 2010 the information on the implementation of the Provincial Assembly decision in multi-lingual forms of certificates from registry books and on the method of entry of data into them, and on this occasion it adopted conclusions charging, inter alia, the Provincial Secretariat for Regulations, Administration and National Minorities to supervise continually the implementation of the mentioned decision in the units of local self-government, especially in the municipalities where no certificate from the registry books in two languages was issued, then in the municipalities where no certificate from the registry books in two languages was issued, namely certificate of citizenship in two languages or no administrative proceedings conducted in minority languages, also indicating the municipality of Bela Crkva.

125. Although there was an option to use Czech language at the Municipal Court in Bela Crkva, according to the information obtained from the Magistrate Court in Vršac (to which, according to the new network of courts of 1 January 2010, the competences of the Municipal Court in Bela Crkva were transferred), no court proceedings were held in this language, and the accused and the witnesses did not use their right to use this minority language. The Magistrate Court in Vršac has a court unit in Bela Crkva, where there is only one judge in charge of civil cases, while criminal proceedings are held in Vršac. After the re-organization of courts and the introduction of the new system, in the forthcoming period the Ministry of Justice intends to pay more attention to the creation of positive measures to facilitate practical use of minority languages at courts, including Czech as well.

\subsubsection{Information on the structured policy for the protection and promotion of Vlach language}

The Committee of Experts encourages the Serbian authorities to adopt a structured policy for the protection and promotion of Vlach and to strengthen its use in public life.

126. As stated in the Section 3.2.2. of the Report, Vlach language is not standardized and the speakers of this language do not agree about its standardization. The very 
example of Vlach language shows that the lack of standardized language represents the basic obstacle for its introduction into public life. Namely, since Vlach language is not standardized the state is not in the position to undertake the activities and measures to organize education in this language, through opening of university institutions where teaching of this language would be organized, which would contribute to the provision of teaching personnel for the performance of teaching in Vlach language in the educational system of the Republic of Serbia. The lack of study of Vlach language further results in the impossibility of use of this language in all spheres of public life, and it generally disables the state to adopt structured policy for the protection and promotion of Vlach language. That is why the standardization of Vlach language is the most important prerequisite for the approach of the state to the issues of full protection of this language. Standardization of Vlach language must be initiated and performed within the framework of Vlach national minority, without interference of the state and the state authorities. In spite of the lack of standardization of this language, in certain spheres which do not require standardization of language there are certain encouragements by the state in using Vlach language, e. g. in information or culture, affirming and promoting this language.

\subsubsection{Information on the activities to provide for the teaching of Part II languages of the Charter}

The Committee of Experts encourages the Serbian authorities to provide for the teaching offin Part II languages within the 3 models of regional or minority language education at all appropriate stages.

127. In relation to the First Periodic Report on the Implementation of the Charter, certain steps forward are reported in the Republic of Serbia in provision for the teaching of Part II languages of the Charter. The section 3.2. contains a review of teaching of these languages at all levels of education, as well as the reasons preventing the organization of teaching in certain languages or their teaching within the school subject of mother tongue with elements of national culture. The adoption of the new Law on Fundamentals of Educational System, as well as the election of national councils of national minorities, which also prescribe the formation of educational boards, will enable essentially new approach to the issues of education in minority languages, too. The Republic of Serbia is willing to support and encourage any initiative in the field of education in minority languages, which would make them an integral part of its educational system. Parallelly to this process, the assumptions to perform education in minority languages must also be ensured in co-operation with all interested social factors, primarily to resolve the issue of deficit of teaching staff by securing continuing education in minority languages.

3.3.4. Information on the activities to promote awareness and tolerance vis-à-vis the minority languages and the cultures they represent 
The Committee of Experts encourages the Serbian authorities to continue their efforts to promote awareness and tolerance vis-à-vis the regional or minority languages and the cultures they represent as an integral part of the cultural heritage of Serbia, both in the general curriculum at all stages of education and in the media.

128. Encouragement and fostering of the spirit of tolerance and inter-cultural dialogue is of priceless importance in multi-ethnic, multi-linguistic and multi-cultural societies such as the society of the Republic of Serbia. The Republic of Serbia undertakes considerable measures at various levels in the development of the spirit of tolerance and inter-cultural dialogue. The implementation of Articles 11 and 12 of the Charter includes the measures of the state and provincial authorities to raise awareness in respect of minority languages and cultures they represent, through co-financing of projects affirming minority languages and developing awareness on the existence of diversities in the Serbian society.

129. The programmes/projects of promotion of multi-cultural and inter-cultural dialogue and better knowledge and understanding between various communities also contribute to the development of the spirit of tolerance, which are cofinanced by the Ministry of Culture - Media Sector. For example, in 2007, out of the totally disbursed sum at the tender (11,170,245.00 dinars), almost two million dinars were awarded to multi-cultural and inter-cultural projects, in 2008 $6,029,772.00$ dinars out of 23,527,056 dinars in total, and at the tender in 2009 in the total sum of $18,118,604.00$ dinars, these projects participated with $3,850,000.00$ dinars. In addition to continuing subsidies to minority media and the support to information in minority languages, since 2009 the Provincial Secretariat of Information of AP of Vojvodina has been issuing the tender for cofinancing projects affirming multi-culture and development of multi-linguistics and inter-culturalism in public media. The amount of funds awarded or this purpose amounted to 3,500,000.00 dinars.

130. In co-operation between the Ministry of State Administration and Local SelfGovernment and the UNDP, the preparation processes of the projects of Promotion of Peace Keeping in the South Serbia and Strengthening of Capacities for Inclusive Local Development in the South Serbia were completed, the implementation of which started at the end of 2009. These two projects are aimed at rendering support to the activities for the maintenance of stability in the South Serbia, and the employees of local self-government and specialized institutions, vulnerable communities, the young and women are the target group. The projects will contribute to the improvement of interethnic understanding and respect for diversities through strengthening of local institutions, improvement of public services rendering and encouragement of economic development. Both the projects are aimed at: improvement of co-living of all nations in the South Serbia; further development of relations between the local population of different nationalities, mainly the Serbs, the Albanians and the Roma through strengthening of local community and institutions in charge of peace making; training of local 
officials, media and the young with the aim to qualify them to mediate and hold dialogues, as well as to raise awareness of gender equality, national tolerance and respect for diversities; promotion of active participation of women, the young and the members of national minorities in political, economic and cultural life; improvement of access to state/local administration bodies for women and the members of national minorities as well as encouragement of equality in power; incitement of economic development and employment; implementation of priority regional development projects and building of capacities of units of local selggovernment to manage migrations. The implementation of the project of Promotion of Peace Keeping in the South Serbia is planned within the period of 2.5 years and the funds had been provided from the Fund for Encouragement of Millennium Development Goals of the Kingdom of Spain (MDGF), while the implementation of the project of Strengthening of Capacities for Inclusive Local Development in the South Serbia is planned within the period of 3 years, while the funds had been provided by the development agencies: SIDA from Sweden, SDC from Switzerland, NOK from Norway, UNDP, BCPR. In addition to the Ministry of State Administration and Local Self-Government, other partners at the national, namely local level are: the Ministry of Youth and Sports, the Ministry of Economy and Regional Development, the Ministry of Education, the Ministry of Health, the Ministry of Labour and Social Policy - Directorate of Gender Equality, the Ministry of Human and Minority Rights, the Office of the Commissioner for refugees, the Co-ordinating Body of the Government of the Republic of Serbia for the Municipalities of Preševo, Bujanovac and Medveđa, the office of the Ombudsman, municipalities and youth offices.

131. The project of the Government of the Autonomous Province of Vojvodina of Affirmation of Multiculturalism and Tolerance in Vojvodina, whose primary goal is to foster cultural diversities and development of the spirit of inter-ethnic tolerance among the citizens of Vojvodina has been successfully implemented since 2005. The main project partner is the Provincial Secretariat for Regulations, Administration and National Minorities. The project has been designed as the complex multi-thematic and multi-cultural programme, aimed at the idea of strengthening of inter-ethnic confidence among the young in Vojvodina. The long-term basic aim of this project is to develop the spirit of tolerance, mutual respect and confidence among the citizens of Vojvodina, with the engagement of all relevant stakeholders. At present, the project is in its fifth stage of implementation. It includes several sub-projects.

- The sub-project of Sports Competitions with an additional content of Tolerance Cup represents organization of sports competitions with additional cultural contents by pupils of primary and secondary schools in five popular team sports, according to the cup system, in 7 towns of Vojvodina. The attention is primarily directed towards the young, as the main target group, and through the cooperation with educational institutions from the whole of Vojvodina a large number of participants has been achieved thus enabling the main message of the project to reach a large number of young people. Together with sports 
competitions, whole day accompanying cultural-entertainment programme is organized for all participants of competitions. The teams are formed as multiethnic teams, and all competitions are covered by multi-lingual signs and referral in the languages of the environments the competitions take place in. Cultural programmes are designed to reflect representation of all communities in the territory of Vojvodina.

- The sub-project of How We Know Each Other includes several activities:

1) The television quiz competition of secondary school pupils in history and culture of national communities from the territory of Vojvodina. The goal of the sub-project is to educate the population, primarily the young, about the common history and culture of various national communities living in Vojvodina. The documentation for the preparation of competitors had been translated into the languages officially used in the territory of AP of Vojvodina, in order to achieve linguistic equality of competitors.

2) How We Know Each Other - Send SMS, a quiz radio version, is designed as a contact programme in the form of a quiz with historical and cultural topics related to national minorities of Vojvodina, where the replies are provided by sending SMS messages for which listeners get awards.

3) We also know it is the competition of disabled persons in knowledge of history and culture of national minorities of Vojvodina.

4) How We Know Each Other - the Book about Vojvodina, is aimed at preparation and publishing of handbooks about Vojvodina, in which relevant experts are included, stressing multi-perspective approach to this issue and promotion of the publication as an additional teaching aid and secondary literature. This project is also partly aimed at education of teaching staff of higher levels of primary and secondary schools, in the sense of improvement of knowledge about the events from common history, cultural and other links of the nations in the territory of Vojvodina. It is planned to print this publication in all officially used languages in AP of Vojvodina, and in English, too.

- The sub-project of Living Together also includes several activities:

1) Homeland on the Danube - Co-living of Germans and Serbs in Vojvodina, implies the preparation of museum exhibition and organization of visits to several towns in Europe (Ulm, Brussels...) and Vojvodina. The goals of these activities are affirmation of positive values from the common history of the two nations, cross-cuttings and cultural influences between the Serbs and the Germans, as a considerable contribution to historic and European experiences in the development of multi-culturalism and multi-ethnic tolerance.

2) Living Together-Co-Living of the Serbs and the Hungarians-Mobile Form, implies the implementation of an exhibition that in an original, modern and multimedia manner presents the topics from the common history and culture and the resulting cross-cutting and influences of the members of the Serbian and the Hungarian community in Vojvodina. The exhibition has been prepared in two languages (Serbian and Hungarian), it is accompanied by catalogues and 
explanations in two languages provided by the custodians who speak both Serbian and Hungarian.

3) Wealth of Diversities prescribes that a tender shall be issued for the best amateurish photograph on the subject of multi-culturalism of Vojvodina, the selection of the best photographs by the expert jury and organization of exhibitions of received photographs in several places in Vojvodina. The direct goal of these activities is to draw the attention of the public to the goals of the project through information about the tender and announcement of the exhibition, namely visits to different places and thus direct promotion of multi-culturalism as the value of Vojvodina through a modern artistic expression.

4) Together is a documentary TV series, which treats and presents diversities of Vojvodina in an original way, as well as the common living and customs of its population. Common history, cross-cuttings and influences, differences and similarities, multi-ethnicity of Vojvodina are presented by means of film and music records. Its television presentation should considerably contribute to system education of population, especially of the young, to better learning about each other, understanding, common living and more tolerant relations. The series is made and broadcasted in the language of the environment where the programmes had been recorded with subsequent dubbing (in several languages officially used in AP of Vojvodina) in order to make it suitable to the large public.

- The sub-project of Media Campaign - Multiculturalism of Vojvodina represents a media promotion and stressing of ideas of multi-culturalism and tolerance as universal values of each society by means of various forms of media presentation, through short messages related to the mentioned topics. It is implemented through print campaign (making of promotional printed matter), television and radio campaign and activities concerning promotion and information to the public about the activities in the implementation of the project.

- The sub-project of Ethno Day implies the creation and organization of the series of presentations of national communities living in Vojvodina with all linguistic, dance, cultural, historic, gastronomic and other characteristics, which are performed by the pupils of primary schools in Vojvodina and training of teaching staff to implement the presentations on their own. The goals of the sub-project are the improvement of awareness and knowledge of different properties of culture, dance, history, etc. of various national communities living in Vojvodina and acceptance of diversities as advantages and wealth of this region.

- The sub-project of Interetno Festival includes arrangement of exhibitions stands - exhibitions of craftsmen works, mixed programmes, ethno concerts, dance and music groups from Vojvodina and abroad, in the form of permanent programmes and programmes of variable contents. It is held every year in Subotica in August. The goal of the project is to provide conditions to learn about the tradition of folk art and cultures of other nations, through participation of the largest possible number of citizens, especially the young, which shall result in direct better 
learning of Vojvodina cultural heritage and contribute to the level of knowledge about multi-cultural Vojvodina.

- The sub-project of Evaluation of State of Inter-Ethnic Relations among the Young in Vojvodina is implemented through expert and system monitoring and evaluation of the present state of inter-ethnic relations among the young in Vojvodina, and through the introduction of the mechanism of monitoring of the state of affairs at educational institutions and training of staff for independent evaluation of state of affairs.

132. All the above mentioned sub-projects and activities deal with the subject of multiculturalism as the value of importance for cultural identity of Vojvodina including respect and affirmation of multi-ethnicity and multi-linguistics in various forms by means of publishing the project documentation in several languages, by providing display and boards in several languages for manifestations, use of traditional names of places at manifestations related to the projects, by applying the criteria of multi-ethnicity when appointing and forming teams of participants in certain project activities, by broadcasting the contents of the project in several languages.

\subsubsection{Information on provision of a stable legal basis for the functioning of national minority councils and magistrate meetings of the Republic of Serbia Council for National Minorities}

The Committee of Experts encourages the Serbian authorities to secure a stable legal basis for the functioning of national minority councils and ensure magistrate meetings of the Republic of Serbia Council for National Minorities.

133. The adoption of the Law on the National Councils of the National Minorities, which rounded the legislative framework for promotion and protection of the rights of national minorities in the Republic of Serbia, also including the rights to use minority languages, and the elections for national councils of national minorities as explained in the Section 2.2.2. of the Report., stable legal basis were secured for the functioning of national councils of national minorities in the Republic of Serbia.

134. The funds for the functioning of national councils of national minorities are provided from the budget of the Republic of Serbia, the budget of the Autonomous Province and the budgets of units of local self-governments, from donations and other income. The Table below contains the data on financing of the functioning of national councils of national minorities from the republic and provincial budgets, which, in the opinion of the authorities of the Republic of Serbia represent a stable financial support for the performance of their activities.

Subsidies from the republic budget for the financing of the functioning of national councils of national minorities, paid through the Ministry of Human and Minority Rights 


\begin{tabular}{|l|r|r|}
\hline \multicolumn{1}{|c|}{ NATIONAL COUNCIL } & Subsidies During 2008 & Subsidies During 2009: \\
\hline the Hungarian National Minority & $21,097,566.00$ & $19,797,776.00$ \\
\hline the Bosniak National Minority & $15,060,516.00$ & $14,104,854.00$ \\
\hline the Romani National Minority & $12,982,716.00$ & $12,150,567.00$ \\
\hline the Croatian National Minority & $11,334,666.00$ & $10,592,802.00$ \\
\hline the Slovak National Minority & $10,176,666.00$ & $9,559,013.00$ \\
\hline the Vlach National Minority & $8,478,216.00$ & $8,029,570.00$ \\
\hline the Romanian National Minority & $8,238,066.00$ & $7,802,987.00$ \\
\hline the Macedonian National Minority & $7,854,966.00$ & $7,434,787.00$ \\
\hline the Bulgarian National Minority & $7,620,819.00$ & $7,222,365.00$ \\
\hline the Bunjevac National Minority & $7,599,516.00$ & $7,194,042.00$ \\
\hline the Ruthenian National Minority & $7,094,316.00$ & $6,755,036.00$ \\
\hline the Ukrainian National Minority & $6,631,866.00$ & $6,316,029.00$ \\
\hline the German National Minority & $6,568,116.00$ & $6,259,383.00$ \\
\hline the Union of Jewish Municipalities of & $6,407,010.00$ & $6,146,091.00$ \\
Serbia & & $6,131,930.00$ \\
\hline the Egyptian National Minority & $6,432,816.00$ & $6,117,768.00$ \\
\hline the Greek National Minority & $6,422,166.00$ & $\mathbf{1 4 1 , 6 1 5 , 0 0 0 . 0 0}$ \\
\hline TOTAL & $\mathbf{1 5 0 , 0 0 0 , 0 0 0 . 0 0}$ & \\
\hline
\end{tabular}

Co-financing of costs for the regular functioning of national councils of national minorities having the seat in the territory of AP of Vojvodina, from the budgetary funds of the Provincial Secretariat for Regulations, Administration and National Minorities

\begin{tabular}{|l|r|r|}
\hline \multicolumn{1}{|c|}{ NATIONAL COUNCIL } & $\mathbf{2 0 0 8}$ & $\mathbf{2 0 0 9}^{\mathbf{3}^{2}}$ \\
\hline the Hungarian National Minority & $11,880,000.00$ & $4,617,500.00$ \\
\hline the Slovak National Minority & $3,375,000.00$ & $1,332,500.00$ \\
\hline the Croatian National Minority & $3,375,000.00$ & $1,331,500.00$ \\
\hline the Romanian National Minority & $2,415,000.00$ & $962,500.00$ \\
\hline the Bunjevac National Minority & $2,030,000.00$ & $799,000.00$ \\
\hline the Ruthenian National Minority & $1,880,000.00$ & $743,000.00$ \\
\hline the Macedonian National Minority & $1,740,000.00$ & $689,000.00$ \\
\hline the Ukrainian National Minority & $1,480,000.00$ & $586,500.00$ \\
\hline the German National Minority & $1,425,000.00$ & $563,500.00$ \\
\hline TOTAL & $\mathbf{2 9 , 6 0 0 , 0 0 0 . 0 0}$ & $\mathbf{1 1 , 6 2 5 , 0 0 0 . 0 0}$ \\
\hline
\end{tabular}

135. The new decree on the Council of the Republic of Serbia for National Minorities secured magistrate meetings of this body. Article 5 of the decree prescribes that the Council shall meet as required, however, at least four times a year. At the request of at least half of the national councils, the president of the Council is obliged to summons a meeting within the period not longer than 30 days.

136. The first meeting of the Council of the Republic of Serbia for National Minorities was held on 30 October 2009, when this body was constituted, the secretary of the

\footnotetext{
${ }^{2}$ Due to the economic crisis, the budget re-balance for 2009 reduced the amount of originally planned funds for financing of the activities of the national councils.

${ }^{3}$ Ibid.
} 
Council was appointed and the Rules of Procedure were adopted. At the request of national councils, the Council recognized the symbols (court of arms and flag) and the national holidays of the Bulgarian, Vlach, Macedonian, Romanian, Ruthenian and Ukrainian national minorities, while for the German and Slovak national minorities it recognized court of arms and flag. The members of the Council agreed that they will discuss the information concerning the state of national minorities in Serbia at the next meeting. 


\title{
4. PART III IMPLEMENTATION OF MEASURES TO PROMOTE USE OF MINORITY LANGUAGES IN ACCORDANCE WITH THE OBLIGATIONS CONTAINED IN ARTICLE 2 PARAGRAPH 2 OF THE CHARTER
}

4.1.

\author{
Article 8 \\ Education \\ Selected paragraphs and sub-paragraphs
}

1. With regard to education, the Parties undertake, within the territory in which such languages are used, according to the situation of each of these languages, and without prejudice to the teaching of the official language(s) of the State:

a)

(iii) to apply one of the measures provided for under (i) and (ii) above at least to those pupils whose families so request and whose number is considered sufficient; or

(iv) if the public authorities have no direct competence in the field of pre-school education, to favour and/or encourage the application of the measures referred to under (i) to (iii) above;

b)

(iv) to apply one of the measures provided for under (i) to (iii) above at least to those pupils whose families so request and whose number is considered sufficient;

c)

(iv) to apply one of the measures provided for under (i) to (iii) above at least those pupils who, or where appropriate whose families, so wish in a number considered sufficient;

d)

(iv) to apply one of the measures provided for under (i) to (iii) above at least to those pupils who, or where appropriate whose families, so wish in a number considered sufficient;

e)

(ii) to provide facilities for the study of these languages as university and higher education subjects; or

f)

(iii) if the public authorities have no direct competence in the field of adult education, to favour and/or encourage the offering of such languages as subjects of adult and continuing education;

g) to make arrangements to ensure the teaching of the history and the culture which is reflected by the regional or minority language; 


\subsubsection{Legislative changes of relevance for the implementation of Article 8 of the Charter}

137. The Law on Fundamentals of Educational System governs the grounds of preschool, primary and secondary education and up-brining. The provision of Article 4 paragraph 1 item 14 of this Law prescribes, inter alia, that the goal of education and up-brining is also to respect and foster tradition and culture of national minorities and ethnic communities, as well as that the educational and up-brining activities are carried out in mother tongue, bilingually or in Serbian language, in accordance with another law. The provision of Article 9 paragraph 2 of this Law prescribes that education and up-brining for the members of national minorities is to be performed in their mother tongue. In exceptional cases, they may also be performed bilingually or in Serbian language, in accordance with another law. In the units of local self-government where the language and script of some national minority is officially used, the document on the network of pre-school institutions and primary schools shall be adopted after previously obtained opinion of the national council of the national minority concerned, the language and script are officially used, namely the language and script are in use in educational and upbrining activities (Article 29 paragraph 4). Article 54 of this Law prescribes that the management bodies of pre-school institutions and schools, consisting of three representatives of each employees, parents and unit of local self-government, shall be appointed and discharged by the assembly of the unit of local selfgovernment. Article 58 paragraph 3 of this Law prescribes that the representatives of national minorities shall be proportionally represented in the council of parents at the institutions where the speakers of minority languages are educated and the representatives of ethnic groups, respectively. At the institutions where educational and up-bringing activities are also carried out in minority language, the members of the management bodies - the representatives of the unit of local self-government will be appointed after the opinion of the relevant national council of national minority had been obtained. At an institution where in the majority of classes education and up-brining are performed in some minority language or if it had been established according to the law governing the competences of national councils of national minorities that they are of particular importance for the national minority concerned, the national council of the national minority shall propose at least one member of the unit of local selfgovernment in the management body (Article 54 paragraphs 4 and 5). At such institutions the management body shall, pursuant to Article 60 paragraph 2, appoint the manager after the opinion of the relevant national council of national minority had been obtained. In Article 69 this Law gives an opportunity to primary and secondary schools to accomplish individual educational programme for minority languages, too for pupils who do not know the language of teaching. The provision of Article 74 paragraph 1 item 4 of this Law prescribes that the curriculum for primary and secondary education shall be adopted in accordance with the established general and special standards and it shall include, inter alia, the recommended method of adjustment of the curriculum of subjects of importance for the national minority concerned and bilingual education. The 
Minister in charge of education shall adopt the curricula for primary and secondary education for the members of national minorities at the proposal of the national council of national minority and the opinion of the National Educational Council (Article 79 paragraph 4). At the proposal of the national council of national minority, the school shall engage an interpreter if there is no other way to test a child in mother tongue enrolled into primary school by the psychologist and the pedagogue, pursuant to the provisions of Article 98 paragraph 4. This Law also prescribes the conditions for the performance of educational and up-brining activities in mother tongue at educational institutions. The provisions of Article 121 paragraphs 6-8 prescribe that the jobs of child minder at pre-school institutions and class teachers, if education and up-bringing are performed in minority language, except for Romani language, may also be performed by a person that had obtained adequate knowledge in the language the education is carried out or passed an exam including methodics, according to the curriculum of an adequate university institution, whereas the jobs of a teacher and expert associate at school may be performed by a person that had obtained secondary, higher or university education in minority language or passed an exam in the language concerned according to the programme of an adequate university institution. A teacher and a teaching assistant shall evidence the knowledge of Romani language before the commission to be established by the Minister also including a proposal of the national council elected for the Romani national minority.

138. The Law on Textbooks and Other Teaching Aids governs preparations, approvals, publishing and selection of textbooks and textbook sets for primary and secondary schools, as well as their monitoring and assessment during the use in educational and up-bringing activities. Article 3 paragraph 2 of this Law prescribes that a textbook shall be printed in minority languages and scripts for pupils for whom education and up-brining are performed in the language concerned. The National Educational Council shall, at the proposal of the Institute for the Promotion of Education and Up-Bringing and the national councils of national minorities, establish the necessity of textbooks in minority language and textbooks in subjects of interest for national minorities (Article 9 paragraph 2). Preparations of textbooks shall be carried out according to the procedure established by this Law, and the Minister in charge of education shall approve textbooks for minority languages and for certain subjects of interest for national minorities at the proposal of the National Educational Council and on the grounds of positive opinion of the national council of national minority. The textbooks approved by the Minister for publishing in Serbian language - after the translation into minority language and script, shall be approved after the expert opinion on the quality of the manuscript of the textbook had been obtained from the Institute for the Promotion of Education and Up-Bringing (Article 20 paragraphs 3 and 4). Pursuant to Article 21 of this Law, the body of the Autonomous Province in charge of educational affairs shall approve publishing and use of the textbooks in the territory of the Autonomous Province, at the proposal of the council concerned and the national council of national minority. This Law gives an option 
to the Minister and to the body in charge of educational affairs in the territory of the Autonomous Province respectively, to approve, at the explained request of an adequate expert body at school, the textbook for the relevant subject and class in use in the native country and that is printed in minority language and script, after the positive opinion of the national council of national minority and the Institute for the Promotion of Education and Up-Bringing had been obtained (Article 28 paragraphs 3 and 4).

139. The Law on Pre-school Education, which governs pre-school education, as a part of uniform system of education and up-bringing, prescribes in Article 5 paragraph 2 that education shall be performed in mother tongue for the members of national minorities, and that it may also be performed bilingually or in Serbian language, if at least $50 \%$ of parents and custodians of children so desire. The statute of a preschool institution shall establish the language in which education shall be performed, and pre-school curriculum shall define the method how to accomplish it. Article 6 of this Law prescribes that a pre-school institution and a school, which implement pre-school curriculum, shall keep records of their activities and issue certificates of attendance of preparatory pre-school classes. If education is performed in minority language, a pre-school institution and a school respectively, which performs preparatory pre-school classes, shall keep records in the language concerned, and forms of certificates of attendance of pre-school classes shall be printed in Serbian language in Cyrillic script and bilingually, in Serbian language and in minority language being officially used. Article 19 of this law provides an option that within the pre-school curriculum it is possible to implement special curricula, including, inter alia, fostering of language and culture of national minorities. More detailed conditions of types, method of accomplishment and financing of those curricula shall be defined by the Minister in charge of educational affairs. This Law also prescribes the number of children who are to enrol into each group organizing education and up-brining of children. Article 32 defines that education and up-bringing in bilingual groups may be implemented if the number of children is for $10 \%$ less than the number of children established by this Law. This Law also specifies fines for offences by pre-school institutions, namely by schools organizing pre-school curriculum, as well as for managers and responsible persons at the institutions concerned, if, inter alia, they do not enable parents to declare in which language their children shall attend preschool classes (Article 53).

140. The national councils of national minorities have, inter alia, special powers at educational institutions where teaching is performed in a minority language or where speech, language or culture of a national minority are taught as a special teaching subject. The national council proposes to the National Educational Council the fundamentals of pre-school programme, curricula and programmes of primary and secondary education for a minority language and gives opinions to the National Educational Council about the curricula for Serbian language as nonmother tongue. The National Educational Council may propose, only under the approval of the national councils of national minorities, to the Minister in charge 
of educational affairs to give approval to use textbooks and teaching aids the contents of which express specific properties of national minorities. The Minister shall approve the use of domestic or imported textbooks in minority languages at the proposal of the national council of national minority.

\subsubsection{Pre-school education - practice}

\section{Teaching language: Albanian}

141. Pre-school education in Albanian language is carried out in the municipalities of Bujanovac, Medveđa and Preševo at 5 pre-school institutions.

\begin{tabular}{|l|l|l|l|l|}
\hline School Year & $\begin{array}{l}\text { Number of } \\
\text { Municipalities (Local } \\
\text { Self-Governments) }\end{array}$ & $\begin{array}{l}\text { Number of Pre-school } \\
\text { Institutions }\end{array}$ & $\begin{array}{l}\text { Number } \\
\text { of } \\
\text { Groups }\end{array}$ & $\begin{array}{l}\text { Number } \\
\text { of } \\
\text { Children }\end{array}$ \\
\hline $2007 / 2008$ & 3 & 5 & 56 & 997 \\
\hline $2008 / 2009$ & 3 & 5 & 54 & 958 \\
\hline $2009 / 2010$ & 3 & 5 & 54 & 843 \\
\hline
\end{tabular}

\section{Bilingual teaching: Serbian and Albanian}

142. Bilingual teaching in Serbian and Albanian languages was carried out at preschool institutions in the above mentioned three municipalities where there were 31 children in the 2007/2008 and 35 children in the 2008/2009 school year.

\section{Teaching language: Bosniak}

143. A pre-school institution in Bosniak is opened with the Islamic Community Board in Novi Pazar, which has 140 children. Teaching is organized in six groups.

\section{Bilingual teaching: Serbian and Bosniak}

144. In Sjenica there is a pre-school institution attended by 350 children in three shifts, but because of the similarity between the two languages there is no precise difference between the speakers of Serbian and Bosniak languages. The procedure of submission of applications and declaration of parents about the language they want their children to study was not carried out at this pre-school institution. In the municipality of Tutin there is a pre-school institution in two locations attended by about 680 children in 45 groups and the state of teaching languages is identical to the one in Sjenica.

\begin{tabular}{|l|l|l|}
\hline MUNICIPALITY & Number of Groups & Number of Children \\
\hline Sjenica & 16 & 350 \\
\hline Tutin & 45 & 680 \\
\hline
\end{tabular}

Teaching language: Bulgarian 
145. There is no organized pre-school education in Bulgarian in the Republic of Serbia.

\section{Bilingual teaching: Serbian and Bulgarian}

146. Bilingual pre-school education in Serbian and Bulgarian is carried out in the municipalities of Bosilegrad and Dimitrovgrad at two pre-school institutions.

\begin{tabular}{|l|l|l|}
\hline School Year & Number of Groups & Number of Children \\
\hline $2007 / 2008$ & 15 & 324 \\
\hline $2008 / 2009$ & 16 & 341 \\
\hline $2009 / 2010$ & 16 & 330 \\
\hline
\end{tabular}

\section{Teaching language: Hungarian}

147. Organized education in Hungarian language is carried out at 20 pre-school institutions in 20 local self-governments in the territory of AP of Vojvodina (Ada, Apatin, Bačka Topola, Bečej, Žitište, Zrenjanin, Kanjiža, Kikinda, Kovin, Kula, Mali Iđoš, Novi Kneževac, Novi Sad, Odžaci, Senta, Sombor, Srbobran, Subotica, Temerin and Čoka) and at three primary schools in Zrenjanin, Nova Crnja and Čantavir.

\begin{tabular}{|l|l|l|l|l|}
\hline School Year & $\begin{array}{l}\text { Number of Local Self- } \\
\text { Governments }\end{array}$ & $\begin{array}{l}\text { Number of Pre-school } \\
\text { Institutions/schools }\end{array}$ & $\begin{array}{l}\text { Number } \\
\text { of } \\
\text { Groups }\end{array}$ & $\begin{array}{l}\text { Number } \\
\text { of } \\
\text { Cchildren }\end{array}$ \\
\hline $2007 / 2008)$ & 22 & 23 & 256 & 4,839 \\
\hline $2008 / 2009$ & 24 & 24 & 245 & 4,602 \\
\hline $2009 / 2010$ & 21 & 23 & 231 & 4,447 \\
\hline
\end{tabular}

\section{Bilingual Education: Serbian and Hungarian}

148. Organized bilingual education in Serbian and Hungarian languages is carried out in 12 local self-governments in the territory of AP of Vojvodina (Ada, Bačka Topola, Bečej, Žitište, Mali Iđoš, Inđija, Pančevo, Srbobran, Senta, Sombor, Subotica and Čoka).

\begin{tabular}{|l|l|l|l|l|}
\hline School Year & $\begin{array}{l}\text { Number of Local Self- } \\
\text { Governments }\end{array}$ & $\begin{array}{l}\text { Number of Pre-school } \\
\text { Institutions }\end{array}$ & $\begin{array}{l}\text { Number } \\
\text { of } \\
\text { Groups }\end{array}$ & $\begin{array}{l}\text { Number } \\
\text { of } \\
\text { Children }\end{array}$ \\
\hline $2007 / 2008$ & 12 & 12 & 54 & 896 \\
\hline $2008 / 2009$ & 12 & 12 & 77 & 1,469 \\
\hline $2009 / 2010$ & 12 & 12 & 47 & 923 \\
\hline
\end{tabular}

Bilingual education: Hungarian and German

149. Organized bilingual education in Hungarian and German languages is carried out at one pre-school institution in Subotica. 


\begin{tabular}{|l|l|l|l|l|}
\hline School Year & $\begin{array}{l}\text { Number of Local Self- } \\
\text { Governments }\end{array}$ & $\begin{array}{l}\text { Number of Pre-School } \\
\text { Institutions }\end{array}$ & $\begin{array}{l}\text { Number } \\
\text { of } \\
\text { Groups }\end{array}$ & $\begin{array}{l}\text { Number } \\
\text { of } \\
\text { Children }\end{array}$ \\
\hline $2007 / 2008$ & 1 & 1 & 1 & 18 \\
\hline $2008 / 2009$ & 1 & 1 & 1 & 22 \\
\hline $2009 / 2010$ & 1 & 1 & 1 & 23 \\
\hline
\end{tabular}

\section{Teaching language: Romani}

150. There is no organized pre-school education in Romani language in the Republic of Serbia.

\section{Bilingual teaching: Serbian and Romani}

151. In the municipalities of Prokuplje, Surdulica, Bela Palanka, Pirot, Bojnik, Lebane, Vladičin Han and towns of Kruševac and Vranje, non-governmental Romani organizations, supported by the donations of REF and UNICEF have formed development educational centres whose purpose is to organize and include Romani children in education, which is carried out bilingually, in Serbian and Romani languages. The table below contains the data about the number of children attending education in two languages in Vranje and Kragujevac.

\begin{tabular}{|l|l|l|l|}
\hline Town & School Year & Number of Groups & Number of Children \\
\hline \multirow{2}{*}{ Vranje } & $2007 / 2008$ & 6 & 230 \\
\cline { 2 - 4 } & $2008 / 2009$ & 6 & 150 \\
\hline Kruševac & $2009 / 2010$ & 6 & 55 \\
\hline
\end{tabular}

152. In AP of Vojvodina in the 2007/2008 school year the programme of care and education for children from 6 months to 3 years and the educational programme for children from 3 years up to the primary school age in Romani language were accomplished for 1,002 children, and in the 2008/2009 school year for 960 children. In relation to the previous year the number of children was decreased for $4.19 \%$.

\section{Teaching language: Romanian}

153. Organized education for children from 3 years of age up to the primary school age in Romanian language is carried out at 5 pre-school institutions in 5 local selfgovernments in the territory of of AP of Vojvodina (Alibunar, Bela Crkva, Žitište, Kovačica, Plandišteand at 4 primary schools in the municipalities of Vršac, Zrenjanin and Pančevo).

\begin{tabular}{|l|l|l|l|l|}
\hline School Year & $\begin{array}{l}\text { Number of Local Self- } \\
\text { Governments }\end{array}$ & $\begin{array}{l}\text { Number of Pre-School } \\
\text { Institutions/schools }\end{array}$ & $\begin{array}{l}\text { Number } \\
\text { of } \\
\text { Groups }\end{array}$ & $\begin{array}{l}\text { Number } \\
\text { of } \\
\text { Children }\end{array}$ \\
\hline $2007 / 2008$ & 4 & 4 & 15 & 175 \\
\hline $2008 / 2009$ & 5 & 5 & 14 & 183 \\
\hline $2009 / 2010$ & 8 & 9 & 17 & 138 \\
\hline
\end{tabular}




\section{Bilingual teaching: Serbian and Romanian}

154. Organized bilingual education in Serbian and Romanian languages is carried out at 4 pre-school institutions and at one primary school in 4 local self-governments (Alibunar, Kovačica, Vršac and Žitište and at the primary school in Uljma, the municipality of Vršac).

\begin{tabular}{|l|l|l|l|l|}
\hline School Year & $\begin{array}{l}\text { Number of Local Self- } \\
\text { Governments }\end{array}$ & $\begin{array}{l}\text { Number of Pre-School } \\
\text { Institutions/schools }\end{array}$ & $\begin{array}{l}\text { Number } \\
\text { of } \\
\text { Groups }\end{array}$ & $\begin{array}{l}\text { Number } \\
\text { of } \\
\text { Children }\end{array}$ \\
\hline $2007 / 2008$ & 3 & 3 & 3 & 40 \\
\hline $2008 / 2009$ & 4 & 4 & 4 & 72 \\
\hline $2009 / 2010$ & 4 & 5 & 5 & 106 \\
\hline
\end{tabular}

\section{Teaching language: Ruthenian}

155. Organized education in Ruthenian language is carried out at 3 pre-school institutions in 3 local self-governments in the territory of AP of Vojvodina (Vrbas, Žabalj and Kula).

\begin{tabular}{|l|l|l|l|l|}
\hline School Year & $\begin{array}{l}\text { Number of Local Self- } \\
\text { Governments }\end{array}$ & $\begin{array}{l}\text { Number of Pre-School } \\
\text { Institutions }\end{array}$ & $\begin{array}{l}\text { Number } \\
\text { of } \\
\text { Groups }\end{array}$ & $\begin{array}{l}\text { Number } \\
\text { of } \\
\text { Children }\end{array}$ \\
\hline $2007 / 2008$ & 3 & 3 & 10 & 173 \\
\hline $2008 / 2009$ & 3 & 3 & 11 & 213 \\
\hline $2009 / 2010$ & 3 & 3 & 8 & 171 \\
\hline
\end{tabular}

\section{Teaching language: Slovak}

156. Organized education in Slovak language is carried out at 5 pe-school institutions in 5 local self-governments of AP of Vojvodina (Alibunar, Bač, Bački Petrovac, Stara Pazova, Novi Sad and at 3 primary schools in 2 local self-governments (Bačka Palanka and Zrenjanin).

\begin{tabular}{|l|l|l|l|l|}
\hline School Year & $\begin{array}{l}\text { Number of Local Self- } \\
\text { Governments }\end{array}$ & $\begin{array}{l}\text { Number of Pre-School } \\
\text { Institutions/schools }\end{array}$ & $\begin{array}{l}\text { Number } \\
\text { of } \\
\text { Groups }\end{array}$ & $\begin{array}{l}\text { Number } \\
\text { of } \\
\text { Children }\end{array}$ \\
\hline $2007 / 2008$ & 6 & 7 & 48 & 1,002 \\
\hline $2008 / 2009$ & 7 & 7 & 48 & 960 \\
\hline $2009 / 2010$ & 7 & 8 & 37 & 785 \\
\hline
\end{tabular}

\section{Bilingual teaching: Serbian and Slovak}

157. Organized bilingual education in Serbian and Slovak languages is carried out at 2 pre-school institutions in 2 local self-governments in the territory of AP of Vojvodina (Pančevo and Bačka Topola). 


\begin{tabular}{|l|l|l|l|l|}
\hline School Year & $\begin{array}{l}\text { Number of Local Self- } \\
\text { Governments }\end{array}$ & $\begin{array}{l}\text { Number of Pre-School } \\
\text { Institutions }\end{array}$ & $\begin{array}{l}\text { Number } \\
\text { of } \\
\text { Groups }\end{array}$ & $\begin{array}{l}\text { Number } \\
\text { of } \\
\text { Children }\end{array}$ \\
\hline $2007 / 2008$ & 3 & 3 & 3 & 50 \\
\hline $2008 / 2009$ & 3 & 3 & 3 & 49 \\
\hline $2009 / 2010$ & 2 & 2 & 2 & 66 \\
\hline
\end{tabular}

\section{Teaching language: Ukrainian}

158. According to the data of the Provincial Secretariat of Education of AP of Vojvodina for the 2009/2010 school year, there are 28 children of Ukrainian nationality in total at pre-school institutions in 4 local self-governments: Vrbas, Inđija, Kula and Sremska Mitrovica. The parents of these children expressed no interest that their children are educated in Ukrainian language for which reason the children of the Ukrainian nationality attend school in Serbian language.

\section{Teaching language: Croatian}

159. Organized education in Croatian language is carried out at one pre-school institution in Subotica.

\begin{tabular}{|l|l|l|l|l|}
\hline School Year & $\begin{array}{l}\text { Number of Local Self- } \\
\text { Governments }\end{array}$ & $\begin{array}{l}\text { Number of Pre-School } \\
\text { Institutions }\end{array}$ & $\begin{array}{l}\text { Number } \\
\text { of } \\
\text { Groups }\end{array}$ & $\begin{array}{l}\text { Number } \\
\text { of } \\
\text { Children }\end{array}$ \\
\hline $2007 / 2008$ & 1 & 1 & 3 & 63 \\
\hline $2008 / 2009$ & 1 & 1 & 3 & 59 \\
\hline $2009 / 2010$ & 1 & 1 & 3 & 58 \\
\hline
\end{tabular}

Bilingual teaching: Serbian and Croatian

160. Organized bilingual education in Serbian and Croatian languages is carried out in Đurđin (Subotica).

\begin{tabular}{|l|l|l|l|l|}
\hline School Year & $\begin{array}{l}\text { Number of Local Self- } \\
\text { Governments }\end{array}$ & $\begin{array}{l}\text { Number of Pre-School } \\
\text { Institutions }\end{array}$ & $\begin{array}{l}\text { Number } \\
\text { of } \\
\text { Groups }\end{array}$ & $\begin{array}{l}\text { Number } \\
\text { of } \\
\text { Children }\end{array}$ \\
\hline $2007 / 2008$ & 1 & 1 & 1 & 22 \\
\hline $2008 / 2009$ & 1 & 1 & 1 & 20 \\
\hline
\end{tabular}

\subsubsection{Primary education - practice}

\section{Teaching in Albanian language}

161. Entire teaching in Albanian language in the Republic of Serbia is carried out at 17 primary schools in the territory of 3 municipalities, in Bujanovac, Medveđa and Preševo.

\begin{tabular}{|l|l|l|l|l|}
\hline School Year & $\begin{array}{l}\text { Number of } \\
\text { Municipalities }\end{array}$ & $\begin{array}{l}\text { Number of } \\
\text { Schools }\end{array}$ & Number of Classes & $\begin{array}{l}\text { Number of } \\
\text { Pupils }\end{array}$ \\
\hline
\end{tabular}




\begin{tabular}{|l|l|l|l|l|}
\hline $2007 / 2008$ & 3 & 17 & 411 & 8,775 \\
\hline $2009 / 2010$ & 3 & 17 & 416 & 8,327 \\
\hline
\end{tabular}

\section{Teaching in Bosniak language}

162. No entire teaching in Bosniak language is carried out at any school in the Republic of Serbia. The study of Bosniak language with elements of national culture as a subject has been introduced into schools in the municipalities of Novi Pazar, Sjenica, Tutin and Prijepolje.

\section{7/2008 School Year}

\begin{tabular}{|l|l|l|l|l|l|l|}
\hline MUNICIPALITY & Grade & $\begin{array}{l}\text { Total } \\
\text { number of } \\
\text { children }\end{array}$ & $\begin{array}{l}\text { Number } \\
\text { of } \\
\text { children } \\
\text { of Bosniak } \\
\text { nationality }\end{array}$ & $\%$ & $\begin{array}{l}\text { Number of } \\
\text { children } \\
\text { who are } \\
\text { learning } \\
\text { Bosniak } \\
\text { language }\end{array}$ & $\%$ \\
\hline Novi Pazar & $\mathrm{I}-\mathrm{V}$ & 7,165 & 6,303 & $88 \%$ & 4,568 & $72 \%$ \\
\hline Sjenica & $\mathrm{I}-\mathrm{V}$ & 1,712 & 1,549 & $90 \%$ & 1,424 & $92 \%$ \\
\hline Tutin & $\mathrm{I}-\mathrm{V}$ & 2,555 & 2,500 & $98 \%$ & 2,500 & $100 \%$ \\
\hline Total & & 11,432 & 10,352 & $90 \%$ & 8,492 & $74 \%$ \\
\hline
\end{tabular}

2008/2009 School Year

\begin{tabular}{|l|l|l|l|}
\hline School Year & $\begin{array}{l}\text { Number of } \\
\text { Municipalities }\end{array}$ & $\begin{array}{l}\text { Number of } \\
\text { Schools }\end{array}$ & $\begin{array}{l}\text { Number of } \\
\text { Pupils }\end{array}$ \\
\hline $2008 / 2009$ & 4 & 22 & 9.738 \\
\hline
\end{tabular}

2009/2010 School Year

\begin{tabular}{|l|l|l|l|l|l|l|}
\hline MUNICIPALITY & Grade & $\begin{array}{l}\text { Total } \\
\text { number of } \\
\text { children }\end{array}$ & $\begin{array}{l}\text { Number of } \\
\text { children of } \\
\text { Bosniak } \\
\text { nationality }\end{array}$ & $\%$ & $\begin{array}{l}\text { Number of } \\
\text { children } \\
\text { who are } \\
\text { learning } \\
\text { Bosniak } \\
\text { language }\end{array}$ & $\%$ \\
\hline Novi Pazar & I-VII & 9,944 & 8,804 & $89 \%$ & 5,396 & $61 \%$ \\
\hline Sjenica & I-VII & 2,264 & 2,050 & $91 \%$ & 1,777 & $87 \%$ \\
\hline Tutin & I-VII & 3,572 & 3,488 & $98 \%$ & 3,471 & $100 \%$ \\
\hline Total & & 15,780 & 14,342 & $91 \%$ & 10,644 & $74 \%$ \\
\hline
\end{tabular}

\section{Teaching in Bulgarian language}

163. Entire teaching in Bulgarian language in the Republic of Serbia is carried out at two primary schools in the municipalities of Bosilegrad and Dimitrovgrad.

\begin{tabular}{|c|c|c|c|c|}
\hline School Year & $\begin{array}{ll}\text { Number } & \text { of } \\
\text { Municipalities } & \end{array}$ & $\begin{array}{l}\text { Number } \\
\text { Schools }\end{array}$ & Number of Classes & $\begin{array}{l}\text { Number of } \\
\text { Pupils }\end{array}$ \\
\hline $2007 / 2008$ & 2 & 2 & 4 & 26 \\
\hline
\end{tabular}




\begin{tabular}{|l|l|l|l|l|}
\hline $2008 / 2009$ & 2 & 2 & 4 & 47 \\
\hline $2009 / 2010$ & 2 & 2 & 3 & 46 \\
\hline
\end{tabular}

164. Bulgarian language with elements of national culture as a subject is taught at two primary schools in the municipalities of Bosilegrad and Dimitrovgrad.

\begin{tabular}{|l|l|l|l|}
\hline School Year & $\begin{array}{l}\text { Number of } \\
\text { Municipalities }\end{array}$ & $\begin{array}{l}\text { Number of } \\
\text { Schools }\end{array}$ & $\begin{array}{l}\text { Number of } \\
\text { Pupils }\end{array}$ \\
\hline $2007 / 2008$ & 2 & 2 & 672 \\
\hline $2008 / 2009$ & 2 & 2 & 675 \\
\hline $2009 / 2010$ & 2 & 2 & 1,330 \\
\hline
\end{tabular}

165. The teaching of Bulgarian language with elements of national culture as a subject is organized at one primary school in the territory of the local community of Ivanovo (the town of Pančevo). Teaching of this subject is organized for 16 pupils from the fifth to the seventh grades. For the first four grades there is no organized teaching of Bulgarian language with elements of national culture as a subject due to the lack of adequate textbooks. The newly elected National Council of the Bulgarian National Minority has already undertaken certain preparatory actions to organize teaching of this subject for pupils of all grades of the mentioned primary school.

\section{Teaching in Hungarian language}

166. Entire teaching in Hungarian language in the Republic of Serbia was carried out in the territory of AP of Vojvodina. In the 2009/2010 school year at 77 regular primary schools in 27 local self-governments (Ada, Apatin, Bačka Topola, Bela Crkva, Bečej, Žitište, Zrenjanin, Kanjiža, Kikinda, Kovačica, Kovin, Kula, Mali Iđoš, Nova Crnja, Novi Bečej, Novi Kneževac, Novi Sad, Odžaci, Pančevo, Plandište, Senta, Sečanj, Sombor, Srbobran, Subotica, Temerin and Čoka).

\begin{tabular}{|l|l|l|l|l|l|}
\hline School Year & $\begin{array}{l}\text { Number of } \\
\text { Municipalities }\end{array}$ & $\begin{array}{l}\text { Number of } \\
\text { Schools }\end{array}$ & $\begin{array}{l}\text { Number of } \\
\text { Classes }\end{array}$ & $\begin{array}{l}\text { Number of } \\
\text { Pupils } \\
\text { Attending } \\
\text { School in } \\
\text { Hungarian }\end{array}$ & $\begin{array}{l}\text { Number of } \\
\text { Pupils of } \\
\text { Hungarian } \\
\text { Nationality }\end{array}$ \\
\hline $2007 / 2008$ & 27 & 78 & 934 & 16,780 & 16,016 \\
\hline $2008 / 2009$ & 27 & 77 & 946 & 16,373 & 15,708 \\
\hline $2009 / 2010$ & 27 & 77 & 969 & 16,168 & 15,516 \\
\hline
\end{tabular}

167. Hungarian language with elements of national culture as a subject was tought in the 2009/2010 school year at 47 regular primary schools in 20 local selfgovernments (Ada, Bačka Topola, Bečej, Vrbas, Vršac, Žitište, Zrenjanin, Inđija, Kanjiža, Kikinda, Kovačica, Kula, Novi Bečej, Novi Sad, Pančevo, Plandište, Senta, Sečanj, Sombor and Srbobran).

\begin{tabular}{|l|l|l|l|}
\hline $\begin{array}{l}\text { School } \\
\text { Year }\end{array}$ & $\begin{array}{l}\text { Number of Local } \\
\text { Self-Governments }\end{array}$ & $\begin{array}{l}\text { Number of } \\
\text { Schools }\end{array}$ & $\begin{array}{l}\text { Number of } \\
\text { Pupils }\end{array}$ \\
\hline
\end{tabular}




\begin{tabular}{|l|l|l|l|}
\hline $2007 / 2008$ & 22 & 48 & 1,585 \\
\hline $2008 / 2009$ & 21 & 50 & 1,570 \\
\hline $2009 / 2010$ & 20 & 47 & 1,463 \\
\hline
\end{tabular}

\section{Teaching in Romani language}

168. No entire teaching in Romani language is carried out at any school in the Republic of Serbia. Although the state has undertaken numerous activities for education of the Roma at all levels, in order to carry out teaching in Romani language it is necessary to fulfil several prerequisites first. The most important one is to define the dialect, i. e. to define the version of Romani language to be used since Romani language is not standardized, and then to approve the textbooks and other teaching aids and train professionally teachers at schools at which teaching in Romani language will be organized. In the accomplishment of these prerequisites the National Council of the Roma National Minority has a crucial role because this very representative body is in charge of all initiatives to provide the conditions for accomplishment of rights prescribed by law, including the field of education as well.

169. Romani language with elements of national culture as a subject was taught in AP of Vojvodina in the 2009/2010 school year at 23 primary schools in 12 local selfgovernments (Ada, Bač, Bačка Palanka, Žabalj, Kikinda, Kovačica, Novi Sad, Odžaci, Srbobran, Sremska Mitrovica, Subotica and Titel).

\begin{tabular}{|l|l|l|l|}
\hline School Year & $\begin{array}{l}\text { Number of } \\
\text { Municipalities }\end{array}$ & $\begin{array}{l}\text { Number of } \\
\text { Schools }\end{array}$ & $\begin{array}{l}\text { Number of pupils } \\
\text { Studying the Subject } \\
\text { of Romani language } \\
\text { with Elements of } \\
\text { national Culture }\end{array}$ \\
\hline $2007 / 2008$ & 13 & 28 & 802 \\
\hline $2008 / 2009$ & 11 & 26 & 584 \\
\hline $2009 / 2010$ & 12 & 23 & 695 \\
\hline
\end{tabular}

\section{Teaching in Romanian language}

170. Entire teaching in Romanian language is organized in one grade at the school in the Ovča dwelling area (the Belgrade municipality of Palilula) for 5 pupils. Entire teaching in Romanian language was carried out in the territory of AP of Vojvodina. In the 2009/2010 school year at 18 primary schools in 9 local selfgovernments (Alibunar, Bela Crkva, Vršac, Žitište, Zrenjanin, Kovačica, Pančevo, Plandište and Sečanj).

\begin{tabular}{|l|l|l|l|l|l|}
\hline & $\begin{array}{l}\text { Number of } \\
\text { Municipalities }\end{array}$ & $\begin{array}{l}\text { Number of } \\
\text { Schools }\end{array}$ & $\begin{array}{l}\text { Number of } \\
\text { Grades }\end{array}$ & $\begin{array}{l}\text { Number of } \\
\text { Pupils } \\
\text { Attending } \\
\text { School in } \\
\text { Romanian }\end{array}$ & $\begin{array}{l}\text { Number of } \\
\text { Pupils of } \\
\text { Romanian } \\
\text { Nationality }\end{array}$ \\
\hline $2007 / 2008$ & 9 & 18 & 92 & 1,396 & 1,203 \\
\hline $2008 / 2009$ & 9 & 18 & 97 & 1,327 & 1,145 \\
\hline
\end{tabular}




\begin{tabular}{|l|l|l|l|l|l|}
\hline $2009 / 2010$ & 9 & 18 & 117 & 1,258 & 1,092 \\
\hline
\end{tabular}

171. Romanian language with elements of national culture as a subject was taught in the territory of the School Administration with the seat in Belgrade at the Vasa Pelagić Primary School in the Ovča dwelling area (the Belgrade municipality of Palilula) in 4 grades for 12 pupils. Teaching of Romanian language with elements of national culture as a subject was organized in the territory of AP of Vojvodina. In the 2009/2010 school year at 9 primary schools in 8 local self-governments (Alibunar, Bač, Žitište, Zrenjanin, Kovačica, Kovin, Plandište and Sečanj).

\begin{tabular}{|l|l|l|l|}
\hline $\begin{array}{l}\text { School } \\
\text { Year }\end{array}$ & $\begin{array}{l}\text { Number of Local } \\
\text { Self-Governments }\end{array}$ & $\begin{array}{l}\text { Number of } \\
\text { Schools }\end{array}$ & $\begin{array}{l}\text { Number of } \\
\text { Pupils }\end{array}$ \\
\hline $2007 / 2008$ & 11 & 13 & 319 \\
\hline $2008 / 2009$ & 10 & 11 & 268 \\
\hline $2009 / 2010$ & 8 & 9 & 244 \\
\hline
\end{tabular}

\section{Teaching in Ruthenian language}

172. Entire teaching in Ruthenian was carried out in the territory of AP of Vojvodina in the 2009/2010 school year at 3 regular schools in 3 local self-governments (Vrbas, Žabalj and Kula).

\begin{tabular}{|l|l|l|l|l|l|}
\hline School Year & $\begin{array}{l}\text { Number of } \\
\text { Municipalities }\end{array}$ & $\begin{array}{l}\text { Number of } \\
\text { Schools }\end{array}$ & $\begin{array}{l}\text { Number of } \\
\text { Classes } \\
\text { Pupils of } \\
\text { Attending } \\
\text { School in } \\
\text { Ruthenian }\end{array}$ & $\begin{array}{l}\text { Number of } \\
\text { Pupils of } \\
\text { Ruthenian } \\
\text { Nationality }\end{array}$ \\
\hline $2007 / 2008$ & 3 & 3 & 35 & 588 & 521 \\
\hline $2008 / 2009$ & 3 & 3 & 35 & 559 & 490 \\
\hline $2009 / 2010$ & 3 & 3 & 34 & 523 & 446 \\
\hline
\end{tabular}

173. Ruthenian language with elements of national culture as a subject was taught in the 2009/2010 school year at 27 regular schools in 7 local self-governments (Bačka Topola, Vrbas, Žabalj, Kula, Novi Sad, Sremska Mitrovica and Šid).

\begin{tabular}{|l|l|l|l|}
\hline $\begin{array}{l}\text { School } \\
\text { Year }\end{array}$ & $\begin{array}{l}\text { Number of Local } \\
\text { Self-Governments }\end{array}$ & $\begin{array}{l}\text { Number of } \\
\text { Schools }\end{array}$ & $\begin{array}{l}\text { Number of } \\
\text { Pupils }\end{array}$ \\
\hline $2007 / 2008$ & 7 & 22 & 286 \\
\hline $2008 / 2009$ & 7 & 24 & 216 \\
\hline $2009 / 2010$ & 7 & 27 & 266 \\
\hline
\end{tabular}

\section{Teaching in Slovak language}

174. Entire teaching in Slovak language was carried out in the territory of AP of Vojvodina. In the 2009/2010 school year at 17 regular schools in 12 local selfgovernments (Alibunar, Bač, Bačka Palanka, Bački Petrovac, Beočin, Zrenjanin, Inđija, Kovačica, Novi Sad, Odžaci, Stara Pazova and Šid).

\begin{tabular}{|l|l|l|l|l|l|}
\hline & Number of & Number of & Number of & Number of & Number of \\
\hline
\end{tabular}




\begin{tabular}{|l|l|l|l|l|l|}
\hline School Year & Municipalities & Schools & Classes & $\begin{array}{l}\text { Pupils } \\
\text { Attending } \\
\text { School in } \\
\text { Slovak }\end{array}$ & $\begin{array}{l}\text { Pupils of Slovak } \\
\text { Nationality }\end{array}$ \\
\hline $2007 / 2008$ & 12 & 17 & 166 & 3,233 & 3,108 \\
\hline $2008 / 2009$ & 12 & 17 & 168 & 3,226 & 3,102 \\
\hline $2009 / 2010$ & 12 & 17 & 172 & 3,178 & 3,062 \\
\hline
\end{tabular}

175. Slovak language with elements of national culture as a subject was taught in the Republic of Serbia at the Branko Radicević Primary School in Boljevci (City municipality of Surcin). In the 2009/2010 school year this subject was studied by 43 pupils from the first to the eighth grades. Slovak language with elements of national culture as a subject was taught in the territory of AP of Vojvodina. In the 2009/2010 school year at 38 regular primary schools in 11 local self-governments (Вас̌ка Palanka, Bačka Topola, Bački Petrovac, Beočin, Vrbas, Zrenjanin, Kovačica, Novi Sad, Pančevo, Planidšte and Šid).

\begin{tabular}{|l|l|l|l|}
\hline $\begin{array}{l}\text { School } \\
\text { Year }\end{array}$ & $\begin{array}{l}\text { Number of Local } \\
\text { Self-Governments }\end{array}$ & $\begin{array}{l}\text { Number of } \\
\text { Schools }\end{array}$ & $\begin{array}{l}\text { Number of } \\
\text { Pupils }\end{array}$ \\
\hline $2007 / 2008$ & 11 & 34 & 588 \\
\hline $2008 / 2009$ & 10 & 37 & 616 \\
\hline $2009 / 2010$ & 11 & 38 & 620 \\
\hline
\end{tabular}

\section{Teaching in Ukrainian language}

176. No entire teaching in Ukrainian language is carried out at any school in the Republic of Serbia. Ukrainian language with elements of national culture as a subject was taught in the 2009/2010 school year in AP of Vojvodina at 9 regular primary schools in 4 local self-governments (Vrbas, Kula, Novi Sad and Sremska Mitrovica).

\begin{tabular}{|l|l|l|l|}
\hline $\begin{array}{l}\text { School } \\
\text { Year }\end{array}$ & $\begin{array}{l}\text { Number of Local } \\
\text { Self-Governments }\end{array}$ & $\begin{array}{l}\text { Number of } \\
\text { Schools }\end{array}$ & $\begin{array}{l}\text { Number of } \\
\text { Pupils }\end{array}$ \\
\hline $2007 / 2008$ & 4 & 9 & 130 \\
\hline $2008 / 2009$ & 4 & 9 & 105 \\
\hline $2009 / 2010$ & 4 & 9 & 114 \\
\hline
\end{tabular}

177. In Budisava, the dwelling area in the territory of the town of Novi Sad, the teaching of Ukrainian language with elements of national culture as the language of the environment was organized for the first time in the 2009/2010 school year for 25 pupils. Only four pupils are Ukrainians and other pupils are of other nationalities.

\section{Teaching in Croatian language}

178. Entire teaching in Croatian language is organized at schools in the territory of AP of Vojvodina. Teaching is organized at 5 regular schools in Subotica. 


\begin{tabular}{|l|l|l|l|l|l|}
\hline School Year & $\begin{array}{l}\text { Number of } \\
\text { Municipalities }\end{array}$ & $\begin{array}{l}\text { Number of } \\
\text { Schools }\end{array}$ & $\begin{array}{l}\text { Number of } \\
\text { Classes }\end{array}$ & $\begin{array}{l}\text { Number of } \\
\text { Pupils } \\
\text { Attending } \\
\text { School in } \\
\text { Croatian }\end{array}$ & $\begin{array}{l}\text { Number of } \\
\text { Pupils of } \\
\text { Croatian } \\
\text { Nationality }\end{array}$ \\
\hline $2007 / 2008$ & 1 & 5 & 14 & 228 & 215 \\
\hline $2008 / 2009$ & 1 & 5 & 20 & 276 & 260 \\
\hline $2009 / 2010$ & 1 & 5 & 32 & 319 & 311 \\
\hline
\end{tabular}

179. Croatian language with elements of national culture as a subject was taught in the 2009/2010 school year at 12 regular primary schools in the territory of 5 local self-governments (Apatin, Bač, Sombor, Sremska Mitrovica and Subotica).

\begin{tabular}{|l|l|l|l|}
\hline School Year & $\begin{array}{l}\text { Number of } \\
\text { Municipalities }\end{array}$ & $\begin{array}{l}\text { Number of } \\
\text { Schools }\end{array}$ & $\begin{array}{l}\text { Number of } \\
\text { Pupils }\end{array}$ \\
\hline $2007 / 2008$ & 3 & 7 & 255 \\
\hline $2008 / 2009$ & 3 & 6 & 257 \\
\hline $2009 / 2010$ & 5 & 12 & 374 \\
\hline
\end{tabular}

\subsubsection{Secondary education - practice}

\section{Teaching in Albanian language}

180. Entire teaching in Albanian language is carried out at 2 grammar schools in the municipalities of Bujanovac and Preševo.

\begin{tabular}{|l|l|l|}
\hline School year & $\begin{array}{l}\text { The Skenderbeg Grammar } \\
\text { School, Preševo }\end{array}$ & $\begin{array}{l}\text { Grammar School in } \\
\text { Bujanovac }\end{array}$ \\
\hline $2007 / 2008$ & 1,041 & 986 \\
\hline $2008 / 2009$ & 1,010 & 1,221 \\
\hline $2009 / 2010$ & 1,067 & 1,364 \\
\hline
\end{tabular}

\section{Teaching in Bosniak language}

181. Entire teaching in Bosniak language as well as the teaching of Bosniak language with elements of national culture as a subject is not organized at any secondary school in the Republic of Serbia.

\section{Teaching in Bulgarian language}

182. 25 pupils attended entire teaching in Bulgarian language in the 2009/2010 school year at the Ćirilo and Metodije Grammar School in Dimitrovgrad.

183. Bulgarian language with elements of national culture as a subject was studied by all 490 pupils at two grammar schools in Bosilegrad and Dimitrovgrad in the 2009/2010 school year.

Teaching in Hungarian language 
184. Entire teaching in Hungarian language was carried out in the territory of AP of Vojvodina. Teaching is carried out at 9 grammar schools (7 standard grammar schools in Bečej, Zrenjanin, Novi Sad, Novi Kneževac, Senta, Sombor and Subotica and at two grammar schools for young talented people in Senta and Subotica).

\begin{tabular}{|l|l|l|l|l|}
\hline School Year & $\begin{array}{l}\text { Number of } \\
\text { Municipalities }\end{array}$ & $\begin{array}{l}\text { Number of } \\
\text { Schools }\end{array}$ & $\begin{array}{l}\text { Number of } \\
\text { Classes }\end{array}$ & $\begin{array}{l}\text { Number of Pupils } \\
\text { Attending School } \\
\text { in Hungarian }\end{array}$ \\
\hline $2007 / 2008$ & 7 & 9 & 54 & 1,119 \\
\hline $2008 / 2009$ & 7 & 9 & 54 & 1,090 \\
\hline $2009 / 2010$ & 7 & 9 & 55 & 1,140 \\
\hline
\end{tabular}

\section{Teaching in Romani language}

185. There is no organized entire teaching in Romani language at secondary schools in the territory of the Republic of Serbia. The reasons for this are the same as the reasons for the lack of entire teaching in Romani language at the level of primary education, which are explained in paragraph 168 of this Report.

\section{Teaching in Romanian language}

186. Entire teaching in Romanian language is organized in the territory of AP of Vojvodina. At the Borislav Petrov Braca Grammar School in Vršac, as a mixed school, the pupils obtain grammar education in Romanian language.

\begin{tabular}{|l|l|l|l|l|}
\hline School Year & $\begin{array}{l}\text { Number of } \\
\text { Municipalities }\end{array}$ & $\begin{array}{l}\text { Number of } \\
\text { Schools }\end{array}$ & $\begin{array}{l}\text { Number of } \\
\text { Classes }\end{array}$ & $\begin{array}{l}\text { Number of } \\
\text { Pupils } \\
\text { Attending } \\
\text { School in } \\
\text { Romanian }\end{array}$ \\
\hline $2007 / 2008$ & 1 & 1 & 4 & 107 \\
\hline $2008 / 2009$ & 1 & 1 & 4 & 114 \\
\hline $2009 / 2010$ & 1 & 1 & 4 & 119 \\
\hline
\end{tabular}

187. Romanian language with elements of national culture as a subject is taught at the Mihajlo Pupin Grammar School in Kovačica and at the Borislav Petrov Braca Grammar School in Vršac.

\begin{tabular}{|l|l|l|}
\hline School Year & $\begin{array}{l}\text { Grammar School in } \\
\text { Kovačica, } \\
\text { Number of Pupils }\end{array}$ & $\begin{array}{l}\text { Grammar } \\
\text { School in Vršac, } \\
\text { Number of } \\
\text { Pupils }\end{array}$ \\
\hline $2007 / 2008$ & 16 & 21 \\
\hline $2008 / 2009$ & 18 & 14 \\
\hline $2009 / 2010$ & 16 & 12 \\
\hline
\end{tabular}

\section{Teaching in Ruthenian language}


188. Entire teaching in Ruthenian language is carried out in the territory of AP of Vojvodina. Teaching in Ruthenian language is carried out at the Petro Kuzmjak Grammar School in Ruski Krstur.

\begin{tabular}{|l|l|l|l|l|}
\hline School Year & $\begin{array}{l}\text { Number of } \\
\text { Municipalities }\end{array}$ & $\begin{array}{l}\text { Number of } \\
\text { Schools }\end{array}$ & $\begin{array}{l}\text { Number of } \\
\text { Classes }\end{array}$ & $\begin{array}{l}\text { Number of Pupils } \\
\text { Attending School } \\
\text { in Ruthenian }\end{array}$ \\
\hline $2007 / 2008$ & 1 & 1 & 4 & 69 \\
\hline $2008 / 2009$ & 1 & 1 & 4 & 60 \\
\hline $2009 / 2010$ & 1 & 1 & 4 & 60 \\
\hline
\end{tabular}

189. The teaching of Ruthenian language with elements of national culture as a subject was organized for the first time in the 2007/2008 school year for 3 pupils at the Isidora Sekulić Grammar School in Novi Sad, and since the 2008/2009 school year it has also been organized at the Sava Šumanović Grammar School in Šid for 23 pupils.

\begin{tabular}{|l|l|l|}
\hline School Year & $\begin{array}{l}\text { The Grammar } \\
\text { School in Novi Sad, } \\
\text { Number of Pupils }\end{array}$ & $\begin{array}{l}\text { The Grammar } \\
\text { School in Šid, } \\
\text { Number of } \\
\text { Pupils }\end{array}$ \\
\hline $2007 / 2008$ & 3 & - \\
\hline $2008 / 2009$ & 2 & 23 \\
\hline $2009 / 2010$ & 2 & 39 \\
\hline
\end{tabular}

\section{Teaching in Slovak language}

190. Entire teaching in Slovak language is carried out in the territory of AP of Vojvodina. Teaching in Slovak language is carried out at 2 grammar schools, the Jan Kolar in Bački Petrovac and the Mihajlo Pupin in Kovačica.

\begin{tabular}{|l|l|l|l|l|}
\hline School Year & $\begin{array}{l}\text { Number of } \\
\text { Municipalities }\end{array}$ & $\begin{array}{l}\text { Number of } \\
\text { Schools }\end{array}$ & $\begin{array}{l}\text { Number of } \\
\text { Classes }\end{array}$ & $\begin{array}{l}\text { Number } \\
\text { of Pupils } \\
\text { Attending } \\
\text { School in } \\
\text { Slovak }\end{array}$ \\
\hline $2007 / 2008$ & 2 & 2 & 14 & 379 \\
\hline $2008 / 2009$ & 2 & 2 & 13 & 341 \\
\hline $2009 / 2010$ & 2 & 2 & 14 & 344 \\
\hline
\end{tabular}

191. The teaching of Slovak language with elements of national culture as a subject is organized at the Grammar School in Bačka Palanka and at the Grammar School in Stara Pazova.

\begin{tabular}{|l|l|l|}
\hline School Year & $\begin{array}{l}\text { The Grammar } \\
\text { School in Bačka } \\
\text { Palanka, } \\
\text { Number of Pupils }\end{array}$ & $\begin{array}{l}\text { The Grammar } \\
\text { School in Stara } \\
\text { Pazova, } \\
\text { Number of } \\
\text { Pupils }\end{array}$ \\
\hline
\end{tabular}




\begin{tabular}{|l|l|l|}
\hline $2007 / 2008$ & 14 & 20 \\
\hline $2008 / 2009$ & 12 & 22 \\
\hline $2009 / 2010$ & 13 & 21 \\
\hline
\end{tabular}

\section{Teaching in Ukrainian language}

192. No entire teaching in Ukrainian language was organized at any secondary school in the Republic of Serbia and Ukrainian language with elements of national culture as a subject is not taught, either, since the pupils did not say they desired so. The Table below contains the number of pupils who are the members of the Ukrainian national minority who attend secondary schools in the territory of AP of Vojvodina.

\begin{tabular}{|l|l|l|l|}
\hline \multirow{2}{*}{ Level of Education } & \multicolumn{3}{|c|}{ School Year } \\
\cline { 2 - 4 } & $\mathbf{2 0 0 6 / 2 0 0 7}$ & $\mathbf{2 0 0 7 / 2 0 0 8}$ & $\mathbf{2 0 0 8 / 2 0 0 9}$ \\
\hline Secondary & 135 & 137 & 138 \\
\hline
\end{tabular}

\section{Teaching in Croatian language}

193. Entire teaching in Croatian language is carried out in the territory of AP of Vojvodina. Teaching in Croatian language is carried out at the Svetozar Marković Grammar School in Subotica.

\begin{tabular}{|l|l|l|l|l|}
\hline School Year & $\begin{array}{l}\text { Number of } \\
\text { Municipalities }\end{array}$ & $\begin{array}{l}\text { Number of } \\
\text { Schools }\end{array}$ & $\begin{array}{l}\text { Number of } \\
\text { Classes }\end{array}$ & $\begin{array}{l}\text { Number of Pupils } \\
\text { Attending School } \\
\text { in Croatian }\end{array}$ \\
\hline $2007 / 2008$ & 1 & 1 & 1 & 15 \\
\hline $2008 / 2009$ & 1 & 1 & 2 & 43 \\
\hline $2009 / 2010$ & 1 & 1 & 2 & 32 \\
\hline
\end{tabular}

194. Within the period from 2007 to 2009 , Croatian language with elements of national culture as a subject was not organized to be taught in the territory of AP of Vojvodina.

\subsubsection{Technical and vocational education - practice}

\section{Teaching in Albanian language}

195. In 2 municipalities, Medveđa and Preševo, entire teaching at 2 secondary technical schools is carried out in Albanian language for the number of pupils shown in the table below:

\begin{tabular}{|l|l|l|}
\hline School Year & $\begin{array}{l}\text { The Secondary Technical } \\
\text { School, } \\
\text { Preševo }\end{array}$ & $\begin{array}{l}\text { The Secondary Technical } \\
\text { School, Medveđa }\end{array}$ \\
\hline $2007 / 2008$ & 827 & 9 \\
\hline $2008 / 2009$ & 1,272 & 14 \\
\hline
\end{tabular}




\begin{tabular}{|l|l|l|}
\hline $2009 / 2010$ & 1,379 & 15 \\
\hline
\end{tabular}

\section{Teaching in Bosniak language}

196. The Gazi Isa-beg Islamic religious secondary school opened in Novi Pazar. Entire teaching is carried out in Bosniak language.

\section{Teaching in Bulgarian language}

197. Since the 2009/2010 school year teaching in Bulgarian language has been organized at the Secondary Tourist School in Dimitrovgrad. Teaching is organized for a class of 16 pupils.

198. Bulgarian language with elements of national culture as a subject is taught at two secondary schools in Bosilegrad and Dimitrovgrad.

\begin{tabular}{|l|l|l|}
\hline School Year & $\begin{array}{l}\text { The Electro- } \\
\text { technical School in } \\
\text { Bosilegrad, } \\
\text { Number of Pupils }\end{array}$ & $\begin{array}{l}\text { The Secondary } \\
\text { School of } \\
\text { Tourism in } \\
\text { Dimitrovgrad, } \\
\text { Number of } \\
\text { Pupils }\end{array}$ \\
\hline $2007 / 2008$ & 46 & 128 \\
\hline $2008 / 2009$ & 33 & 129 \\
\hline $2009 / 2010$ & 33 & 128 \\
\hline
\end{tabular}

\section{Teaching in Hungarian language}

199. Entire teaching in Hungarian language is carried out in the territory of AP of Vojvodina. Teaching in Hungarian language is carried out at 24 specialized schools, one mixed school and at two art schools.

\begin{tabular}{|l|l|l|l|l|}
\hline School Year & $\begin{array}{l}\text { Number of } \\
\text { Municipalities }\end{array}$ & $\begin{array}{l}\text { Number of } \\
\text { Schools }\end{array}$ & $\begin{array}{l}\text { Number of } \\
\text { Classes }\end{array}$ & $\begin{array}{l}\text { Number of Pupils } \\
\text { Attending School } \\
\text { in Hungarian }\end{array}$ \\
\hline $2007 / 2008$ & 12 & 26 & 258 & 5,529 \\
\hline $2008 / 2009$ & 12 & 26 & 254 & 5,397 \\
\hline $2009 / 2010$ & 12 & 27 & 257 & 5,362 \\
\hline
\end{tabular}

200. At the request of pupils attending school in Serbian language, teaching of Hungarian language with elements of national culture as a subject is organized as follows: in 2007 for four pupils of the Polytechnic School in Subotica and five pupils of the Technical School in Temerin in 2008 for three pupils of the Technical School in Ada.

\section{Teaching in Romanian language}

201. Entire teaching in Romanian language is carried out in the territory of AP of Vojvodina. Teaching in Romanian language is carried out at the Dositej Obradović Economic-Commercial School in Alibunar. 


\begin{tabular}{|l|l|l|l|l|}
\hline School Year & $\begin{array}{l}\text { Number of } \\
\text { Municipalities }\end{array}$ & $\begin{array}{l}\text { Number of } \\
\text { Schools }\end{array}$ & $\begin{array}{l}\text { Number of } \\
\text { Classes }\end{array}$ & $\begin{array}{l}\text { Number of Pupils } \\
\text { Attending School } \\
\text { in Romanian }\end{array}$ \\
\hline $2007 / 2008$ & 1 & 1 & 4 & 98 \\
\hline $2008 / 2009$ & 1 & 1 & 4 & 117 \\
\hline $2009 / 2010$ & 1 & 1 & 4 & 118 \\
\hline
\end{tabular}

\section{Teaching in Ruthenian language}

202. No entire teaching in Ruthenian language is organized at any technical or specialized secondary school in the territory of the Republic of Serbia. In the territory of AP of Vojvodina, teaching of the subject of Ruthenian language with elements of national culture was organized for the first time in the 2008/2009 school year for 2 pupils of the 7. april Medical School in Novi Sad.

\section{Teaching in Slovak language}

203. No entire teaching in Slovak language is organized at any technical or specialized secondary school in the territory of the Republic of Serbia. Teaching of the subject of Slovak language with elements of national culture is organized at schools in the territory of AP of Vojvodina. In the 2007/2008 school year it was organized at 3 secondary schools in Stara Pazova and at 2 secondary schools in Вас̌ка Palanka and in the 2008/2009 school year it was organized at the Technical School in Stara Pazova and at 3 secondary schools in Bас̌ка Palanka. In the 2009/2010 school year teaching of this subject was organized at 2 secondary schools in Bačка Palanka and at 2 secondary schools in Stara Pazova.

\begin{tabular}{|l|l|l|l|l|}
\hline School Year & $\begin{array}{l}\text { Number of } \\
\text { Municipalities }\end{array}$ & $\begin{array}{l}\text { Number of } \\
\text { Schools }\end{array}$ & $\begin{array}{l}\text { Number of } \\
\text { Classes }\end{array}$ & $\begin{array}{l}\text { Number of pupils } \\
\text { studying the } \\
\text { subject of Slovak } \\
\text { language with } \\
\text { elements of } \\
\text { national culture }\end{array}$ \\
\hline $2007 / 2008$ & 2 & 5 & 18 & 148 \\
\hline $2008 / 2009$ & 2 & 4 & 12 & 127 \\
\hline $2009 / 2010$ & 2 & 4 & 12 & 97 \\
\hline
\end{tabular}

\subsubsection{University education - practice}

\section{Albanian language}

204. The Branches of the Faculty of Economics and the Faculty of Law of the University of Niš started working in Medveđa in the 2009/2010 school year. At the Branch of the Faculty of Economics 19 students were enrolled, of whom 4 students are of the Albanian nationality and the Branch of the Faculty of Law 35 students were enrolled, of whom 7 students are of the Albanian national minority. The students of the Albanian national minority attend classes in Serbian language with simultaneous interpretation of lectures into Albanian language. The 
textbooks and teaching aids have been translated into Albanian language and examinations will be arranged in Albanian language, too.

205. Albanian language and literature are studied in the Republic of Serbia at Faculty of Philology in Belgrade, Department of Albanian Language and Literature.

Number of students studying Albanian language and literature at the Faculty of Philology in Belgrade

\begin{tabular}{|l|l|l|}
\hline School Year & $\begin{array}{l}\text { Students Enrolled in } \\
\text { First Year }\end{array}$ & $\begin{array}{l}\text { Total Number of } \\
\text { Students in 4 } \\
\text { Years }\end{array}$ \\
\hline $2007 / 2008$ & 17 & 59 \\
\hline $2008 / 2009$ & 16 & 56 \\
\hline $2009 / 2010$ & 9 & 35 \\
\hline
\end{tabular}

\section{Bosniak language}

206. Bosniak language is studied at two university institutions in Novi Pazar. At the State University, Department of Philosophic - Philological Sciences, within the Department of Serbian Language and Literature, there is a possibility to study Bosniak language as an optional subject. Upon the completion of studies, the following bachelor degrees are gained: bachelor in Serbian language, bachelor in Bosniak language, or combined - bachelor in Serbian-Bosniak languages, which is the most frequent choice of the students. It is possible to study Bosniak language as an optional subject at the University of Novi Pazar, Department of Serbian/Bosnian Language as Teaching Subjects. Teaching is carried out in Serbian language and upon the completion of studies the graduates gain a degree of a teacher of Serbian and Albanian language, respectively, depending on optional subjects. The Tables below contain the data about the number of students who attend the above mentioned lectures.

Number of students at the State University, Department of Philosophic - Philological Sciences in Novi Pazar

\begin{tabular}{|l|l|}
\hline School Year & Number of Students \\
\hline $2007 / 2008$ & 40 \\
\hline $2008 / 2009$ & 40 \\
\hline $2009 / 2010$ & 40 \\
\hline
\end{tabular}

Number of students at the University of Novi Pazar, Department of Serbian/Bosnian Language as Teaching Subjects

\begin{tabular}{|l|l|}
\hline School Year & Number of Students \\
\hline $2007 / 2008$ & 8 \\
\hline $2008 / 2009$ & 31 \\
\hline $2009 / 2010$ & 30 \\
\hline
\end{tabular}




\section{Bulgarian language}

207. Bulgarian language and literature are studied in the Republic of Serbia at the Faculty of Philology in Belgrade, Department of Bulgarian Language and Literature.

Number of students studying Bulgarian language and literature at the Faculty of Philology in Belgrade

\begin{tabular}{|l|l|l|}
\hline School Year & $\begin{array}{l}\text { Students Enrolled in } \\
\text { First Year }\end{array}$ & $\begin{array}{l}\text { Total Number of } \\
\text { Students in all 4 } \\
\text { Years }\end{array}$ \\
\hline $2007 / 2008$ & 13 & 49 \\
\hline $2008 / 2009$ & 12 & 46 \\
\hline $2009 / 2010$ & 13 & 25 \\
\hline
\end{tabular}

\section{Hungarian language}

208. In the Republic of Serbia, university education in Hungarian language is provided in the territory of AP of Vojvodina, as follows: at 5 faculties (Faculties of Philosophy, Economics, Natural Sciences, Civil Engineering and Teaching) in Novi sad and Subotica, the Academy of Arts in Novi Sad and at 3 higher schools of vocational studies (the Higher School of Vocational Studies for Education of Pre-School Teacher in Novi Sad, the Higher School of Vocational Studies for Education of Pre-School Teachers in Subotica and the Higher Technical School of Vocational Studies in Subotica). The table below contains the data about the number of students studying in Hungarian language.

\begin{tabular}{|l|l|l|}
\hline School Year & Faculties & $\begin{array}{l}\text { Higher School } \\
\text { of Vocational } \\
\text { Studies }\end{array}$ \\
\hline $2007 / 2008$ & 583 & 688 \\
\hline $2009 / 2010$ & 617 & 535 \\
\hline
\end{tabular}

209. Hungarian language and literature are studied in the Republic of Serbia at the Faculty of Philology in Belgrade, Department of Hungarian Language and Literature and at the Faculty of Philosophy in Novi Sad, Department of Hungarian Studies, Section of Hungarian Language and Literature. The Tables below contain the data about the number of students at the above mentioned faculties.

Number of students studying Hungarian language and literature at the Faculty of Philology in Belgrade

\begin{tabular}{|l|l|l|}
\hline School Year & $\begin{array}{l}\text { Students Enrolled in } \\
\text { First Year }\end{array}$ & $\begin{array}{l}\text { Total Number of } \\
\text { Students in All 4 } \\
\text { Years }\end{array}$ \\
\hline $2007 / 2008$ & 8 & 41 \\
\hline $2008 / 2009$ & 13 & 42 \\
\hline
\end{tabular}




\begin{tabular}{|l|l|l|}
\hline $2009 / 2010$ & 9 & 21 \\
\hline
\end{tabular}

Number of students studying Hungarian language and literature at the Faculty of Philosophy in Novi Sad

\begin{tabular}{|l|l|}
\hline School Year & Number of Students \\
\hline $2007 / 2008$ & 129 \\
\hline $2008 / 2009$ & 133 \\
\hline $2009 / 2010$ & 99 \\
\hline
\end{tabular}

\section{Romani language}

210. The teaching for education of pre-school teachers was organized for the first time in both Serbian and Romani languages at the Higher School of Vocational Studies for Education of Pre-School Teachers in Vršac in the 2009/2010 school year. The first group of 5 students was enrolled. The teaching of Romani language with elements of national culture, methodics and exercises as subjects is carried out in Romani language and since this is only the beginning of education in Romani language there are no professors engaged yet to deliver lectures in other subjects in Romani language.

211. In the Republic of Serbia, Romani language and literature as a subject are studied at the School of Romani Studies in Novi Sad and at the European Centre for Peace and Development of the United Nations Peace University in Belgrade. The initiative to establish the School of Romani Studies was made in 2004 as a part of ACIMSI University Studies of the Gender Studies Centre (Female Studies and Researches). The Faculty of Philosophy from Novi Sad, the Institute of Culture of Vojvodina and Romani non-governmental organizations contributed to the establishment of this School. The School of Romani Studies has been organized in the form of seminars, workshops, debates and performances, and the following subjects are studied: fundamentals of Romani studies, Romani language, Romani culture, history and religion, and since lately, learning about the Decade of Roma Inclusion, as well as about the elements of application in the programmes for primary schools. The School of Romani Studies has been attended in cycles by students, postgraduates, journalists, non-governmental organizations and since 2010 a seminar has been organized for teachers, pedagogues and psychologists. The European Centre for Peace and Development of the United Nations Peace University has been implementing the study programme for master and doctor degrees in Romani studies since 2010.

\section{Romanian language}

212. Two university institutions in Vršac, Department of Teacher Training Faculty in Belgrade - Department of Romanian Language (Romanian as mother tongue) and the Higher School of Vocational Studies for Pre-School Teachers have complete 
teaching in Romanian language in the Republic of Serbia. The tables below contain the data about the number of students at the above mentioned faculties.

Number of students at the Teacher Training Faculty in Belgrade - Department in Vršac

\begin{tabular}{|l|l|}
\hline School Year & Number of Students \\
\hline $2007 / 2008$ & 14 \\
\hline $2008 / 2009$ & 14 \\
\hline $2009 / 2010$ & 16 \\
\hline
\end{tabular}

Number of students at the Higher School of Vocational Studies for Pre-School Teachers in Vršac

\begin{tabular}{|l|l|}
\hline School Year & Number of Students \\
\hline $2007 / 2008$ & 20 \\
\hline $2008 / 2009$ & 20 \\
\hline $2009 / 2010$ & 20 \\
\hline
\end{tabular}

213. Romanian language and literature are studied in the Republic of Serbia at the Faculty of Philology in Belgrade, Department of Romanian Language and Literature and at the Faculty of Philosophy in Novi Sad, Department of Romanian Studies, Section of Romanian Language and Literature. The Tables below contain the data about the number of students at the above mentioned faculties.

Number of students studying Romanian language and literature at the Faculty of Philology in Belgrade

\begin{tabular}{|l|l|l|}
\hline School Year & $\begin{array}{l}\text { Students Enrolled in } \\
\text { First Year }\end{array}$ & $\begin{array}{l}\text { Total Number of } \\
\text { Students in all 4 } \\
\text { Years }\end{array}$ \\
\hline $2007 / 2008$ & 12 & 54 \\
\hline $2008 / 2009$ & 11 & 57 \\
\hline $2009 / 2010$ & 13 & 49 \\
\hline
\end{tabular}

Number of students studying Romanian language and literature at the Faculty of Philosophy in Novi

\begin{tabular}{|l|l|}
\multicolumn{1}{c}{ Sad } \\
\hline School Year & Number of Students \\
\hline $2007 / 2008$ & 41 \\
\hline $2008 / 2009$ & 33 \\
\hline $2009 / 2010$ & 22 \\
\hline
\end{tabular}

\section{Ruthenian language}

214. Ruthenian language and literature are studied in the Republic of Serbia at the Faculty of Philosophy in Novi Sad, Department of Ruthenian Studies, Section of Ruthenian Language and Literature. The Table below contains the data about the number of students at the above mentioned faculty.

\section{Number of students studying Ruthenian language and literature at the Faculty of Philosophy in Novi Sad}

\begin{tabular}{|l|l|}
\hline School Year & Number of Students \\
\hline
\end{tabular}




\begin{tabular}{|l|l|}
\hline $2007 / 2008$ & 19 \\
\hline $2008 / 2009$ & 23 \\
\hline $2009 / 2010$ & 25 \\
\hline
\end{tabular}

\section{Slovak language}

215. The teaching is carried out in Slovak language at the Higher School of Vocational Studies for Pre-School Teachers in Novi Sad. The Table below contains the data about the number of students at the above mentioned institution.

Number of students at the Higher School of Vocational Studies for Pre-School Teachers In Novi Sad

\begin{tabular}{|l|l|}
\hline School Year & Number of Students \\
\hline $2007 / 2008$ & 5 \\
\hline $2008 / 2009$ & 5 \\
\hline $2009 / 2010$ & 12 \\
\hline
\end{tabular}

216. Slovak language and literature are studied in the Republic of Serbia at the Faculty of Philology in Belgrade, Department of Slovak Language and Literature and at the Faculty of Philosophy in Novi Sad, Department of Slavic Studies, Section of Slovak Language and Literature. The Tables below contain the data about the number of students at the above mentioned faculties.

Number of students studying Slovak language and literature at the Faculty of Philology in Belgrade

\begin{tabular}{|l|l|l|}
\hline School Year & $\begin{array}{l}\text { Students Enrolled in } \\
\text { First Year }\end{array}$ & $\begin{array}{l}\text { Total Number of } \\
\text { Students in All 4 } \\
\text { Years }\end{array}$ \\
\hline $2007 / 2008$ & 8 & 41 \\
\hline $2008 / 2009$ & 15 & 48 \\
\hline $2009 / 2010$ & 10 & 48 \\
\hline
\end{tabular}

Number of students studying Slovak language and literature at the Faculty of Philosophy in Novi Sad

\begin{tabular}{|l|l|}
\hline School Year & Number of Students \\
\hline $2007 / 2008$ & 30 \\
\hline $2008 / 2009$ & 29 \\
\hline $2009 / 2010$ & 30 \\
\hline
\end{tabular}

\section{Ukrainian language}

217. Ukrainian language and literature are studied in the Republic of Serbia at the Faculty of Philology in Belgrade, Department of Ukrainian Language and Literature and at the Faculty of Philosophy in Novi Sad, Section of Ruthenian Language and Literature. Since the 2006/2007 school year Ukrainian has been introduced as a compulsory two-semester subject at the second year of studies for all students studying at the Section of Ruthenian Language and Literature.

Number of students studying Ukrainian language and literature at the Faculty of Philology in Belgrade 


\begin{tabular}{|l|l|l|}
\hline School Year & $\begin{array}{l}\text { Students Enrolled in } \\
\text { First Year }\end{array}$ & $\begin{array}{l}\text { Total Number of } \\
\text { Students in All 4 } \\
\text { Years }\end{array}$ \\
\hline $2007 / 2008$ & 16 & 45 \\
\hline $2008 / 2009$ & 17 & 47 \\
\hline $2009 / 2010$ & 13 & 35 \\
\hline
\end{tabular}

\section{Croatian language}

218. Contemporary Serbian and Croatian languages are studied at the Department of South Slavic Philology of the Faculty of Philology in Belgrade at the second, the third and the fourth years of studies.

\subsubsection{Adult education - Practice}

219. The table below contains the data about primary education of adults in Hungarian as a teaching language.

\begin{tabular}{|l|l|l|l|}
\hline $\begin{array}{l}\text { School } \\
\text { Year }\end{array}$ & $\begin{array}{l}\text { Number of Local } \\
\text { Self-Governments }\end{array}$ & $\begin{array}{l}\text { Number of } \\
\text { Schools }\end{array}$ & $\begin{array}{l}\text { Number of } \\
\text { Attendees }\end{array}$ \\
\hline $2007 / 2008$ & 3 & 3 & 113 \\
\hline $2008 / 2009$ & 3 & 3 & 96 \\
\hline
\end{tabular}

220. In the 2009/2010 school year the education for adults included 370 members of the Roma nationality in total, which is 27 attendees more than the previous school year (or 7.87\%). Out of this number, education for 358 Roma is in Serbian and for 12 of them in Hungarian as a teaching language.

\subsubsection{Activities for the implementation of box-recommendation of the Committee of Experts concerning Article 8 of the Charter}

221. In the Report on the implementation of the Charter in the first reporting cycle, the Committee of Experts stated the following recommendation:

The Committee of Experts encourages the Serbian authorities to develop a coherent strategy in the field of teacher training and provide adequate teaching materials for regional or minority language education.

222. In 2007 the Government of the Republic of Serbia adopted the Strategy of Specialized Education Development in the Republic of Serbia. This Strategy provides the initial grounds for raising the general level of pedagogic capabilities and skills of teachers, ensuring the conditions for their continuing professional training and permanent professional advancement, in order to carry out modernization of the curricula (experiments), innovate teaching process with new contents, organization and new methods and carry out modernization of equipment and teaching aids by introducing new information technologies. Professional training of teachers is governed by laws and by-laws, whereas there 
is no detachment of training and qualifications for the performance of teaching in minority languages. It is noticed that in the Republic of Serbia there are unsatisfactory circumstances primarily in relation to the lack of teachers to implement curricula in education in minority languages at all levels of education, and then in respect of their insufficient continuing professional training. One of the possibilities to overcome such circumstances might be to implement the agreements on co-operation with certain states in the field of education (see Section 3.1.9. of the Report), as well as within the activities of inter-state commissions, which are established according to bilateral agreements on protection of national minorities. Namely, reactivation of inter-state commissions ensures realistic grounds to establish adequate solutions in respect of both professional and vocational training of teachers in minority languages in the countries signatories to such agreements.

223. The Republic of Serbia has been making efforts to provide in due time and under the same conditions teaching aids for teaching in minority languages and that teaching materials are of the same quality as for children attending school in Serbian language. The newly adopted Law on Textbooks and Teaching Aids, which prescribes procedures for approval and printing of textbooks in minority languages, as well as the method of import of textbooks from mother countries, should ensure quality and satisfactory coverage of curricula by means of adequate textbooks for education in minority languages. The national councils of national minorities, with clearly established competences, have a decisive word in making initiatives and selection of teaching materials for education in minority languages. 
Article 9

\section{Judicial Authorities}

\section{Selected paragraphs and sub-paragraphs}

1. The Parties undertake, in respect of those judicial districts in which the number of residents using the regional or minority languages justifies the measures specified below, according to the situation of each of these languages and on condition that the use of the facilities afforded by the present paragraph is not considered by the judge to hamper the proper administration of justice:

\section{a) in criminal proceedings:}

(ii) to guarantee the accused the right to use his/her regional or minority language; and/or

(iii) to provide that requests and evidence, whether written or oral, shall not be considered inadmissible solely because they are formulated in a regional or minority language; and/or

\section{b) in civil proceedings:}

(ii) to allow, whenever a litigant has to appear in person before a court, that he or she may use his or her regional or minority language without thereby incurring additional expense; and/or

\section{c) in proceedings before courts concerning administrative matters:}

(ii) to allow, whenever a litigant has to appear in person before a court, that he or she may use his or her regional or minority language without thereby incurring additional expense; and/or

d) to take steps to ensure that the application of sub-paragraphs (i) and (iii) of paragraphs b) and c) above and any necessary use of interpreters and translations does not involve extra expense for the persons concerned.

\section{The Parties undertake:}

a) not to deny the validity of legal documents drawn up within the State solely because they are drafted in a regional or minority language; or

b) not to deny the validity, as between the parties, of legal documents drawn up within the country solely because they are drafted in a regional or minority language, and to provide that they can be invoked against interested third parties who are not users of these languages on condition that the contents of the document are made known to them by the person(s) who invoke(s) it; or 
c) not to deny the validity, as between the parties, of legal documents drawn up within the country solely because they are drafted in a regional or minority language.

3. The Parties undertake to make available in the regional or minority languages the most important national statutory texts and those relating particularly to users of these languages, unless they are otherwise provided.

\subsubsection{Legislation relevant for the implementation of Article 9 of the Charter}

224. The relevant legislation for the implementation of Article 9 of the Charter is explained in the Section 5.2.1. of the First Periodic Report on the Implementation of the Charter in Serbia. After the first cycle of monitoring of the implementation of the Charter, the Law on Amendments and Supplements to the Law on Official Use of Language and Script was adopted (see Section 2.1.1. of this Report), which amended Article 11 of this Law. In the amended Article 11 paragraph 3 it is defined that official use of languages of national minorities also implies in particular, inter alia, the use of languages of national minorities in administrative and court proceedings and conduct of administrative and court proceedings in minority languages. The provisions on official use of language at courts are also contained in the laws governing criminal, civil and administrative court proceedings, which are also contained in the relevant explanations of accepted paragraphs of Article 9 of the Charter.

\subsubsection{Criminal proceedings}

225. The Criminal Procedure Code, in the part regulating the basic principles of criminal proceedings, prescribes that every accused person, namely every suspect, has the right to be informed as soon as possible, and not later than at the first interrogation, in details and in the language he/she understands, about the act he/she is charged with, about the nature and reasons of charges and evidence against him/her (Article 4 paragraph 1 item 1), as well as to have an interpreter if he/she does not understand or does not speak the language used in the proceedings (Article 4 paragraph 1 item 7). The provision of Article 7 prescribes that Serbian language and Cyrillic script are officially used in criminal proceedings. Other languages and scripts are officially used pursuant to law (paragraph 1). At courts in the territories where the members of national minorities live, their languages and scripts are also officially used in criminal proceedings, in accordance with the Constitution and law (paragraph 2). The provision of Article 8 prescribes that actions, appeals and other applications are to be addressed to courts in the language officially used at court (paragraph 1). A foreign citizen deprived of liberty may address applications to court in his/her mother tongue (paragraph 2). The provision of Article 9 is very important prescribing that criminal proceedings are conducted in the language officially used at court (paragraph 1), and that parties, witnesses and other persons participating in the proceedings have the right to use their language in the 
proceedings. If the proceedings are not held in the language of the person concerned, interpretation of what he/she is going to state and what other persons are going to state shall be provided on the account of budgetary funds, as well as the translations of documents and other written evidence (paragraph 2). The right to interpretation/translation is explained in paragrapha 2 of this Article, which the person concerned may waive if he/she knows the language of the proceedings. It will be recorded in the minutes that the instructions had been given and what the participant stated (paragraph 3). Interpretation is entrusted to an interpreter (paragraph 4). Also, the provision of Article 10 prescribes that summons, decisions and other writings shall be addressed to court in Serbian language (paragraph 1). If some minority language is also officially used at court, the court shall deliver writings in the language the members of the national minority used at court. The persons concerned may request the writings to be submitted to them in the language the proceedings are held (paragraph 2). An accused in detention, who is serving sentence or who is at health institution for security reasons shall also receive a translation of the writing referred to in paragraph 1 of this Article in the language used in the proceedigns (paragraph 3). The provision of Article 11 prescribes that courts communicate between each other and render legal aid to each other in the language officially used at court. If writing is prepared in some minority language and is addressed to court in the language not officially used at it, a translation into Serbian shall be enclosed. In the part of this Law related to the proceedings in respect of ordinary legal remedies, governing the proceedings on appeal against the first instance judgement, Article 368 paragraph 1 item 3 prescribes that there is a material violation of the provisions of criminal proceedings if the main hearing is held without the presence of a person whose presence is compulsory accroding to the Code, or if the accused, the defender, the damaged person as the plaintiff or the private plaintiff, contrary to his/her request, is deprived of the use of his/her language at the main hearing and to monitor the course of the main hearing in his/her language (Article 9).

226. The regulations in force concerning the organization of courts do not prescribe that special records are to be kept at courts in the Republic of Serbia on the grounds of which it would be possible to render the data about the number of proceedings, including criminal proceedings, too, which had been entirely held in in some minority language, the number of criminal proceedings in which the accused used minority language, and about the number of criminal proceedings held in Serbian language wherein the participants exercised the right to use minority language. For the requirements of preparation of this Report, the Ministry of Human and Minority Rights conducted a questionnaire at the beginning of 2010 on the necessity to use minority languages at courts. Since the questionnaire was conducted at the time of the beginning of application of the reformed netowork of courts, when also there was the taking over of the court documentation between former municipal and district courts respectively, to newly established courts, the data obtained from courts may only be used as an illustration of the use of minority languages in criminal proceedings, because more precise records are needed to show the actual circumstances. The following 
paragraphs give examples of use of minority languages in criminal proceedings, but only for those courts that had accepted to take part in the preparation of this Report.

The Magistrate Court in Vršac, for the territory of municipalities of Bela Crkva, Vršac and Plandište, with court units in Bela Crkva and Plandište Hungarian/Romanian/Slovak/Czech/

227. Entire criminal proceedings were conducted in Romanian language in one case at the Magistrate Court in Vršac. In 5 criminal proceedings the accused used Romanian language. In 3 criminal cases the participants in the proceedings used Romanian language. This court covered the costs of interpretation for the participants exercising the right to use minority languages.

The Magistrate Court in Zrenjanin, for the territory of municipalities of Žitište, Novi

Bečej, Sečanj and for the town of Zrenjanin, with court units in Novi bečej and Sečanj

Hungarian/Romanian/Slovak

228. Entire criminal proceedings were conducted in Romanian language in one case at the Magistrate Court in Zrenjanin. In one criminal case the accused used Romanian language. The costs of interpretation were covered by the court.

The Magistrate Court in Pančevo, for the territory of municipalities of Alibunar, Kovačica, Kovin, Opovo and for the town of Pančevo, with court units in Alibunar, Kovačica and Kovin

Hungarian/Romanian/Slovak

229. At the seat of the Magistrate Court in Pančevo criminal proceedings are entirely held in Romanian language in one case, while in the previous period there were no proceedings entirely held in some minority language officialy used in the territory of the present Magistrate Court. In one case before the Municipal Court in Kovačica the accused used Romanian language as his mother tongue and gave statements through an interpreter. In the proceedings held in Serbian language, the participants used minority languages in 7 criminal cases before the Municipal Court in Alibunar and in 3 criminal cases before the Municipal Court in Kovačica. The courts covered the costs of interpretation for the participants using minority languages.

The Magistrate Court in Subotica, for the territory of municipalities of Ada, Bačka Topola, Kanjiža, Mali Iđoš and Senta and for the town of Subotica, with court units in Ada, Bačka Topola, Kanjiža and Senta

Hungarian/Croatian

230. A certain number of proceedings in criminal cases were held in Hungarian language before the Magistrate Court in Subotica, as follows: 40 cases in 2007, 37 cases in 2008 and 20 cases in 2009. 
The High Court in Leskovac for the territory of the Magistrate Court in Leskovac

Albanian

231. In the territory of the High Court in Leskovac, in 4 criminal cases the accused used Albanian language. In one criminal case in the proceedings held in Serbian language one witness used Albanian language. The court covered the costs of interpretation for the participants using minority language.

The High Court in Novi Sad for the territory of the Magistrate Court in Novi Sad Hungarian/Ruthenian/Slovak

232. At the Criminal Department of the High Court in Novi Sad, in 23 criminal cases the accused and witnesses requested the presence of an interpreter on the occasion of their interrogation, which costs were covered by the court. In several cases the accused submitted bilingual power-of-attorney for defence or the damaged persons submitted bilingual power-of-attorney for representation, in Serbian and minority language.

The High Court in Pančevo for the territory of the Magistrate Court in Vršac and the Magistrate Court in Pančevo

Hungarian/Romanian/Slovak/Czech

233. In the proceedings in respect of rogatories before the High Court in Pančevo Romanian language was used in 4 criminal cases. In those cases interrogations were held through interpreters, whose services were paid on the account of budgetary funds.

The High Court in Subotica for the territory of the Magistrate Court in Subotica Hungarian/Croatian

234. According to the data of the Criminal Department of the High Court in Subotica, no entire criminal proceedings were held in some minority language in some minority language officially used before the District Court in Subotica. There were proceedings in which the accused used some of the minority languages officially used in the territory of the court, and in the total number of 691 cases it is not possible to establish the exact number of such cases. It is also impossible to establish the number of testimonies and written evidence submitted, namely the number of the same submitted in minority languages in the criminal proceedings held in Serbian language. In criminal proceedings held in Serbian language the participants exercised the right to use some minority language officially used. Based on the data concerning the payment of costs of interpretation covered by the court concerned in 2007, the participants exercised the right to use minority language in 153 cases, in 289 cases in 2008 and in 249 cases in 2009.

\subsubsection{Civil proceedings}


235. In the first part of the Law on Civil Procedure governing the basic provisions of the civil proceedings, in the provision of Article 6 it is prescribed that civil proceedings shall be held in Serbian language of ekavian dialect or jekavian dialect and Cyrillic script shall be used in such proceedings, while Latin script shall be used in accordance with the Constitution and law. In the territories where the language of certain national minority is officially used pursuant to the law, the proceedings are also held in the language of the national minority concerned using the script of the national minority, too (paragraph 1). The parties and other participants in the proceedings have the right to use their languages and scripts, in accordance with the provisions of this Law (paragraph 2). The provision of Article 96 prescribes that the parties and other participants in the proceedings have the right to use their language at hearings and the occasion of oral undertaking of procedural actions before the court. If the proceedings are not held in the language of the party, namely in the language of other participants in the proceedings, at their request interpretation into their language shall be provided of what is going to be said at the hearing, as well as interpretation of the documents that are going to be used at the hearing for the production of evidence (paragraph 1 ). The parties and other participants in the proceedings shall be instructed about the right to attend oral proceedings before the court in their language through an interpreter. It shall be stated in the Minutes that they had been instructed about their right and the statements of the parties, namely of the participants (paragraph 2 ). Interpreters are engaged to do interpreting (paragraph 3). The provision of Article 97 prescribes that summons, decisions and other court writings are delivered to the parties and other participants in the proceedings in Serbian language (paragraph 1). If some of national minority languages is also officially used before the court, the court shall deliver court writings in the language concerned to those parties and participants in the proceedings who are the members of the national minority concerned and who use the language concerned in the proceedings (paragraph 2). The provision of Article 98 prescribes that the parties and other participants in the proceedings shall address their actions, appeals and other submissions in the language officially used before the court (paragraph 1). The parties and other participants in the proceedings may also address their submissions to the court in the language of national minorities not officially used before the court, if it is in accordance with the law (paragraph 2). The provision of Article 99 prescribes that the costs of interpretation into the language of national minorities, which result from the application of the provisions of the Constitution and this Law concerning the right of the members of national minorities to use their language are to be covered by the court. Also, in Chapter 13, which governs the procedure of legal aid rendering, the provision of Article 171 prescribes that courts shall communicate in the language officially used before them (paragraph 1). If some writing is made in the language of national minority, and is to be addressed to the court in the language of the national minority concerned not officially used before the court, a translation of the writing into Serbian language shall be enclosed to the writing (paragraph 2). Chapter 20 concerns production of evidence. In the part governing the position of 
witnesses, the provision of Article 246 prescribes that a witness who does not know the language of the proceedings shall be examined through an interpreter (paragraph 1). The court shall warn the interpreter of the duty to truly interpret the questions asked and the statements to be expressed by the witness (paragraph 3 ). Chapter 27 governs the issue of proceedings upon legal remedies. In the part concerning ordinary legal remedies it is prescribed that an appeal against a judgement may be also filed because of the material violation of the provisions of civil proceedings, which exists if the court does not apply or if it applies in wrong way some of the provisions of this Law, if it effects or if it might have effected the adoption of lawful and proper judgement. There is always a material violation of civil proceedings if, inter alia, contrary to the provisions of the law the dismissed a motion of the party to freely use his/her language and script in the proceedings (Article 361 paragraph 2 item 8).

236. The regulations in force concerning the organization of courts do not prescribe that special records are to be kept at courts in the Republic of Serbia on the grounds of which it would be possible to render the data about the number of proceedings, including civil proceedings, too, which had been entirely held in some minority language, the number of civil proceedings in which the accused used minority language, and about the number of civil proceedings held in Serbian language wherein the participants exercised the right to use minority language. For the requirements of preparation of this Report, the Ministry of Human and Minority Rights conducted a questionnaire at the beginning of 2010 on the necessity to use minority languages at courts. Since the questionnaire was conducted at the time of the beginning of application of the reformed network of courts, when also there was the taking over of the court documentation between former municipal and district courts respectively, to newly established courts, the data obtained from courts may only be used as an illustration of the use of minority languages in civil proceedings, because more precise records are needed to show the actual circumstances. The following paragraphs give examples of use of minority languages in civil proceedings, but only for those courts that had accepted to take part in the preparation of this Report.

The Magistrate Court in Vršac, for the territory of municipalities of Bela Crkva, Vršac and Plandište, with court units in Bela Crkva and Plandište

Hungarian/Romanian/Slovak/Czech

237. Testimonies in Romanian language were delivered in Romanian language in one civil case before the Municipal Court in Vršac. In 4 civil cases the participants in the proceedings used Romanian language. This court covered the costs of interpretation for the participants exercising their right to use minority language concerned.

The Magistrate Court in Zrenjanin, for the territory of municipalities of Žitište, Novi Bečej, Sečanj and for the town of Zrenjanin, with court units in Novi Bečej and Sečanj Hungarian/Romanian/Slovak 
238. Entire civil proceedings were conducted in Hungarian language in 3 case before the Magistrate Court in Zrenjanin. 10 probate proceedings were held in Hungarian language. The costs of interpretation were covered by the court. In 29 cases in civil proceedings an interpreter was engaged for the parties or witnesses. In 29 cases in the proceedings held in Serbian language the parties exercised their right to use minority language. In the proceedings held in Serbian language, the court covered the costs of interpretation for the participants exercising their right to use official minority language.

The Magistrate Court in Leskovac, for the territory of municipalities of Bojnik, Vlasotince, Lebane, Medveda and Crna Trava and for the town of Leskovac, with court units in Vlasotince and Lebane

Albanian

239. In one case in the civil proceeding before the Magistrate Court in Leskovac - the court unit in Lebane, the party used Albanian language. The court covered the costs of interpretation.

The Magistrate Court in Pančevo, for the territory of municipalities of Alibunar, Kovačica, Kovin, Opovo and the town of Pančevo, with court units in Alibunar, Kovačica and Kovin

Hungarian/Romanian/Slovak

240. In the proceedings held before the Municipal Court in Kovin (Hungarian and Romanian) in the officially used minority languages, there were testimonies in the languages concerned, and before the Municipal Court in Alibunar there were testimonies and written evidence submitted in minority languages (Romanian and Slovak). In the proceedings held in Serbian language, minority language was used in 16 civil cases before the Municipal Court in Alibunar and in 16 civil cases and 5 contentious cases before the Municipal Court in Kovačica. The courts covered the costs of interpretation for the participants using minority language, except for the Municipal Court in Kovin.

The Magistrate Court in Subotica, for the territory of municipalities of Ada, Bačka Topola, Kanjiža, Mali Iđoš and Senta and for the town of Subotica, with court units in Ada, Bačka Topola, Kanjiža and Senta

Hungarian/Croatian

241. A certain number of proceedings in civil cases were held in Hungarian language before the Magistrate Court in Subotica, as follows: 94 cases in 2007, 111 cases in 2008 and 127 cases in 2009.

The High Court in Leskovac

Albanian 
242. In the territory of this court, in the proceedings held in Serbian language in one civil case one witness used Albanian language. The court covered the costs of interpretation for the participants exercising their right to use minority language.

The High Court in Subotica

Hungarian/Croatian

243. According to the data of the Civil Department of the High Court in Subotica, 36 entire proceedings were held in officially used minority language, as follows: 23 cases in 2007, 8 cases in 2008 and 5 cases in 2009. In civil proceedings held in Serbian language, there were testimonies and written evidence submitted in minority language but it is not possible to establish the exact number of such cases. The court covered the costs of interpretation in 4 cases for the participants exercising their right to use minority language.

\subsubsection{Administrative disputes}

244. Part I, Chapter 1 of the Law on General Administrative Procedure, concerning general principles of general administrative procedure, govern the use of language and script in the procedure concerned. The provision of Article 16 prescribes that the body shall conduct the proceedings in Serbian language in ekavian or jekavian dialects and Cyrillic script shall be used in such proceedings, while Latin script shall be used in accordance with the Constitution and law. In the territories where the language of certain national minority is officially used pursuant to the law, the proceedings are also held in the language of the national minority concerned using the script of the national minority, too (paragraph 1). If the proceedings are not held in the language of the party, namely in the language of other participants in the proceedings, who are the citizens of the Republic of Serbia, an interpreter shall be provided to interpret the course of the proceedings into their language, as well as the delivery of summons and other writings in their language and script (paragraph 2). The parties and other participants in the proceedings who are not the citizens of the Republic of Serbia have the right to attend the hearing in their language through an interpreter and to use their language in the proceedings (paragraph 3). Also, In the part governing production of evidence, namely the position of witnesses, the provision of Article 169 prescribes that a witness shall be examined through an interpreter if he/she does not know the language of the proceedings (paragraph 1). Chapter 15 governs the repetition of the proceedings. The provision of Article 239 prescribes that the proceedings ended in the decision against which there is no ordinary legal remedy (final decision) may be repeated, inter alia, if the person participating in the proceedings had no opportunity to use his/her language and script under the conditions of Article 16 of this Law (item 11). At the end of 2009 the new law on administrative disputes was adopted, as the result of harmonization with the Constitution of the Republic of Serbia and international standards, especially with the principles and rules of the European Convention for Protection of Human Rights and Fundamental Freedoms. Article 8 
paragraph 1 of this Law establishes that an administrative dispute shall be resolved by the Administrative Court. Article 74 prescribes that the provisions of the law governing civil proceedings shall be accordingly applied to the issues of the proceedings for resolution of administrative disputes not regulated by this Law, including also, inter alia, the provisions of Article 6 of the Law on Civil Procedure governing the issue of use of language and script in civil proceedings, namely the use of other languages and scripts.

\subsubsection{Activities for the implementation of box-recommendation of the Committee of Experts concerning Article 9 of the Charter}

245. In the Report on the Implementation of the Charter in the first reporting cycle, the Committee of Experts established two box-recommendations regarding Article 9 of the Charter. The following paragraphs contain information on the activities undertaken by the State in order to implement them.

\subsubsection{Information to citizens about the possibility of using minority languages in courts}

The Committee of Experts encourages the Serbian authorities to actively inform citizens about the possibility of using a regional or minority language in courts.

246. In the Section 5.2.1. of the First Periodic Report on the implementation of the Charter in Serbia, it is stressed that the establishment of the language of the proceedings is the issue to be decided on by the person conducting the proceedings, pursuant to the provisions of this Law. The court the proceedings are to be held before is obliged to inform the party about the languages officially used in the territory of the court and to request the party to declare in which language the proceedings are to be held. Article 13 of the Law on Official Use of language and Script prescribes that the method of establishment of the language of the proceedings and the established language of the proceedings shall be specified in the Minutes, and Article 14 of this Law prescribes that the Minutes and the decisions adopted in the first instance proceedings and referring to the proceedings concerned shall be made, as authentic texts in Serbian language and in minority language, if the proceedings had been conducted in minority language. The rights of the members of national minorities to use their language through the assistance of interpreters if the proceedings are not held in their language are respected before the court. In the court proceedings, any violation of the right to use one's own language and script is always treated as a relatively material violation of the rules of the procedure, and for this reason, it is investigated in each particular case whether such a violation might have effected the final decision.

247. In co-operation with the Mission of OESC to Serbia, the Ministry of Justice printed a brochure and the poster under the title of Judiciary Reform for All Citizens, which had been submitted to all courts to inform the members of the 
national minorities about their rights, as well as about the method of functioning of the new network of courts. In the forthcoming period the Ministry of Justice intends to pay more attention to the creation of positive measures in order to facilitate practical use of minority language at courts.

\subsubsection{Availability of the most important statutory texts in minority languages}

The Committee of Experts encourages the Serbian authorities to make available in the regional or minority languages the most important national statutory texts and those relating particularly to users of these languages, to be identified in cooperation with the speakers.

248. Article 26 of the Statute of AP of Vojvodina governs that Serbian language and Cyrillic script shall be officially used at the bodies and organizations of AP of Vojvodina, as well as Hungarian, Slovak, Croatian, Romanian and Ruthenian languages and their scripts, in accordance with the law and the decision of the Provincial Assembly. The Provincial Secretariat for Regulations, Administration and National Communities (Department of the Official Gazette of AP of Vojvodina and publishing of regulations) takes care of the publishing of the Official Gazette of AP of Vojvodina, which is, in addition to Serbian language, also published in Hungarian, Slovak, Romanian, Ruthenian and Croatian languages and scripts. Also, the Translation Pool of the Provincial Secretariat for Regulations, Administration and National Communities provides interpretations and translations from Serbian into Hungarian, Croatian, Slovak, Romanian and Ruthenian languages and vice versa. In addition to the sessions of the Assembly of AP of Vojvodina, the decisions adopted by the Assembly and the Government of AP of Vojvodina are also interpreted and translated, which are then published in the Official Gazette of AP of Vojvodina. The Translation Pool has additionally translated into the officially used minority languages in the territory of AP of Vojvodina, the most important national legal regulations concerning in particular the users of those languages (the Constitution of the Republic of Serbia, the Law on Prohibition of Discrimination, the Law on the National Councils of the National Minorities, etc.). The Internet page of the Provincial Secretariat for Regulations, Administration and National Communities also provides an option to see and take over the documents of this Secretariat in Hungarian, Slovak, Romanian, Ruthenian and Croatian languages in addition to Serbian language. 
4.3.

Article 10

Administrative Authorities and Public Services Selected paragraphs and sub-paragraphs

1. Within the administrative districts of the State in which the number of residents who are users of regional or minority languages justifies the measures specified below and according to the situation of each language, the Parties undertake, as far as this is reasonably possible:

a)

(iv) to ensure that users of regional or minority languages may submit oral or written applications in these languages; or

(v) to ensure that users of regional or minority languages may validly submit a document in these languages;

c) to allow the administrative authorities to draft documents in a regional or minority language.

2. In respect of the local and regional authorities on whose territory the number of residents who are users of regional or minority languages in such as to justify the measures specified below, the Parties undertake to allow and/or encourage:

b) the possibility for users of regional or minority languages to submit oral or written applications in these languages;

c) the publication by regional authorities of their official documents also in the relevant regional or minority languages;

d) the publication by local authorities of their official documents also in the relevant regional or minority languages;

g) the use or adoption, if necessary in conjunction with the name in the official language(s), of traditional and correct forms of place-names in regional or minority languages.

3. With regard to public services provided by the administrative authorities or other persons acting on their behalf, the Parties undertake, within the territory in which regional or minority languages are used, in accordance with the situation of each language and as far as this is reasonably possible:

c) to allow users of regional or minority languages to submit a request in these languages.

4. With a view to putting into effect those provisions of paragraphs 1, 2 and 3 accepted by them, the Parties undertake to take one or more of the following measures: 
c) compliance as far as possible with requests from public service employees having a knowledge of a regional or minority language to be appointed in the territory in which that language is used.

5. The Parties undertake to allow the use or adoption of family names in the regional or minority languages, at the request of those concerned.

\subsubsection{Submission of applications in minority languages to the state administration bodies}

249. In the Section 5.3.1. of the First Periodic Report on the implementation of the Charter, the right to written and oral referral to the administrative bodies is explained in details, as prescribed by the Constitution of the Republic of Serbia and the national regulations (the Law on Protection of Rights and Freedoms of National Minorities, the Law on the Official Use of Language and Script, the Law on General Administrative Procedure and the Decision on Precise Regulation of Certain Issues of Official Use of National Minority Languages and Scripts in the territory of AP of Vojvodina). In relation to the first cycle of monitoring of the implementation of the Charter, the provision of Article 11 paragraph 8 of the Law on the Official Use of Language and Script is also an improvement of the right to refer to the republic bodies in minority language, the amendments and supplements of which are explained in details in the Section 2.1.1. of the Report. Namely, this paragraph prescribes that the members of national minorities whose number in the total population of the Republic of Serbia does not reach $2 \%$ according to the last census, may refer to the republic bodies in their language and have the right to receive a reply in the language concerned through the unit of local self-government where the language of national minority is officially used, whereas the unit of local self-government shall provide the translation and cover the costs of the translation of the letter addressed to the republic body and of the reply by the body concerned.

\subsubsection{Submission of applications in minority languages to local or regional authorities}

250. In respect of submission of applications in minority languages to local or regional authorities within the period covered by this Report, the legislative framework has not been amended compared to the previous one and it is contained in the Section 5.3.4 of the First Periodic Report on the implementation of the Charter.

251. In practice, according to the data received from the units of local self-government the number of oral and written applications of speakers of minority languages to local authorities is in co-relation with the participation of speakers of minority languages in the total number of population of the unit of local self-government. The parties have the right to refer to the bodies orally or in writing in their language and in practice there are reasonable possibilities to accomplish this right, except in case of some places with the low percentage of speakers of minority 
languages. The data obtained from the units of local self-government that had accepted to participate in the preparation of this Report do not make it possible to show total data about the applications of parties in certain minority languages under different circumstances. Nevertheless, for example, in the municipality of Ada there were 4 administrative cases in which applications were submitted in Hungarian language. in the municipality of Ada the administrative proceedings were held in Serbian language in which the party used Slovak language through an interpreter the costs of whom were covered by the municipality. In the municipality of Žitište, 90 administrative proceedings were held in Serbian language and the parties used minority language, which were conducted by the expert associates of the municipal administration knowing Romanian and Hungarian languages (officially used minority languages). At the bodies of the town of Zrenjanin, there were 73 administrative proceedings conducted in Serbian language wherein the parties used some of officially used minority languages, whereas the costs were covered by administration bodies. The total number of administrative proceedings held entirely in Hungarian language before the administrative bodies of the town of Subotica amounted to 29,162, and in Croatian to 5,570. In the municipality of Bujanovac, the number of applications of citizens in Albanian language to municipal authorities amounted to several hundreds. In the municipality of Preševo there were 3,100 proceedings held in Albanian language. In the municipality of Sjenica, the number of applications in Bosniak language is relatively small.

252. An insight in submission of requests to local authorities in minority languages may be directly made on the grounds of the data about certificates from registry books and certificates from the books of citizens. According to the information by the Provincial Secretariat for Regulations, Administration and National Communities, in towns and municipalities of AP of Vojvodina in 2008, where in addition to Serbian language minority languages and scripts were also officially used, 10,864 certificates from the registry books were issued in bilingual forms (5,962 certificates were issued in Serbian-Hungarian forms, 18 certificates were issued in Serbian-Romanian forms, 30 certificates were issued in SerbianRuthenian forms, 2,724 certificates were issued in Serbian-Slovak forms and 2,130 certificates were issued in Serbian-Croatian forms). Out of 16,106 certificates from the registry books issued in 2009, 7,485 certificates were issued in Serbian-Hungarian forms, 30 certificates were issued in Serbian-Romanian forms, 30 certificates were issued in Serbian-Ruthenian forms, 5,426 certificates were issued in Serbian-Slovak forms and 3,135 certificates were issued in Serbian-Croatian forms. If we compare the total number of issued bilingual certificates with the number of municipalities and towns, the largest number of bilingual certificates was issued in the municipality of Bački Petrovac, where out of the total number of 4,585 issued certificates from registry books, 3,984 certificates were issued in Serbian-Slovak forms (in the course of 2008, 1,597 certificates in total were issued in Вас̌кi Petrovac, of which 1,577 certificates were in Serbian-Slovak forms). 449 certificates from the registry books were issued in 2008 in minority languages officially used in the units of local self- 
government: 139 certificates in Serbian-Hungarian forms, 1 certificate was issued in Serbian-Romanian form, 11 certificates were issued in Serbian-Ruthenian forms, 271 certificates were issued in Serbian-Slovak forms and 27 certificates were issued in Serbian-Croatian. 870 certificates from the registry books were issued in 2009 in some officially minority languages, as follows: 334 certificates in Serbian-Hungarian forms, 16 certificates were issued in Serbian-Ruthenian forms, 503 certificates were in Serbian-Slovak forms and 17 certificates were issued in Serbian-Croatian. No certificates were issued in Serbian-Romanian forms. As for the registry book of citizens in officially used minority languages, 1,518 certificates were issued in 2008, as follows: 342 certificates in SerbianHungarian forms, 1 certificate was issued in Serbian-Romanian form, 209 certificates in Serbian-Slovak forms and 966 certificates in Serbian-Croatian forms. No certificates from the registry book of citizens were issued in SerbianRuthenian and Serbian-Czech forms. 1,395 certificates were issued in total in 2009, as follows: 510 certificates in Serbian-Hungarian forms, 12 certificates in Serbian-Ruthenian forms, 422 certificates in Serbian-Slovak forms and 451 certificates in Serbian-Croatian forms. No certificates from the registry book of citizens were issued in Serbian-Romanian and Serbian-Czech forms.

253. Submission of applications in minority languages to local authorities has also been facilitated by prescribing that knowledge of relevant minority languages is required according to the documents of systematization of jobs in certain units of local self-governments. According to the information available by the Provincial Secretariat for Regulations, Administration and National Communities of AP of Vojvodina, out of the total number of towns and municipalities where minority language is also officially used, in the majority of them (19), a condition for employment of adequate number of officials is, according to the document on internal organization and systematization of jobs, that they know the relevant language of national minority. Even in those units of local self-government where it is not a condition of employment (16), a certain number of officials working with parties or conducting administrative proceedings know the minority language officially used. Based on the Decision of the Assembly of AP of Vojvodina on the exam in minority language passed for the jobs with the administrative authorities (2003), which establishes an exam as the method of check-up of knowledge of such languages for the jobs with the bodies of local self-government and provincial administrative bodies, the employees are enabled to improve their knowledge of some of minority languages. Certificate of exam passed obtained in accordance with this decision may be used for the jobs with the administrative authorities if an adequate level of knowledge of a foreign or a minority language had been established as a condition to perform jobs and duties, but it may also be used with other bodies and legal entities if their documents prescribe that an adequate knowledge of language is required to perform certain jobs. In the course of 2008 there were 8 certificates of knowledge of a minority language issued, while in 2009 there were 11 certificates issued in total. In relation to the initial great interest of candidates to pass the above mentioned exam, this interest has been decreased three times these last years. In order to 
provide improvement of knowledge of minority languages, the Provincial Secretariat for Regulations, Administration and National Communities of AP of Vojvodina continued organizing specialized language courses for the employees of administrative authorities and judiciary, for those who conduct proceedings or communicate with parties in minority languages concerned. The seventh seminar for employees communicating in Hungarian was held in 2009 in co-operation with the National Council of Hungarian National Minority. In the territory of AP of Vojvodina, 21 local self-governments have permanently employed interpreters/translators for minority languages. In 10 town or municipal administrations, translations are provided at the request of the party, and in 8 administrations there were no requests to provide translations.

254. As a rule, the provincial authorities receive applications from parties in Serbian language. Slightly more frequent applications in some minority language (mostly in Hungarian), due to the nature of its business, are reported at the Provincial Secretariat for Regulations, Administration and National Communities. This Provincial Secretariat issues tenders to finance organizations and manifestations of national minorities as well as of the traditional churches and religious communities. The text of the tender is published in all official languages and the tender documents (forms) are also provided in official languages of AP of Vojvodina. The organizations of various national minorities and churches mainly gathering the members of national minorities exercise the right to use language in writing in various scopes. According to the analysis of submitted applications, it may be concluded that the organizations of the Hungarians exercise the right to use mother tongue to the largest extent. Namely, according to the available data, out of 176 applications submitted by various organizations for support to organizations of ethnic communities in AP of Vojvodina at the tender issued in 2008, 154 applications were in Hungarian, and out of 141 report in total submitted for this tender (four reports were bilingual), 112 were in Hungarian language. In 2009 two tenders were issued for these purposes. At the first tender, in respect of organizations gathering Hungarians, out of 168 received applications in total, 138 applications were in Hungarian language, and out of 40 received reports, 30 were in Hungarian. At the second tender, there were 185 applications submitted in total, of which 164 were in Hungarian language, and out of the received reports, all six reports were in Hungarian language. Differences in using mother tongue indicate that the members of various national minorities whose language had been recognized as an official language, do not have identical requirements in respect of official use of their own language. Writings received in officially used minority languages are translated, if necessary, and replies are provided in minority languages, too. The Translation Pool also renders translation services to other provincial authorities.

\subsubsection{Publishing of regional documents in minority languages}

255. In the First Periodic Report on the Implementation of the Charter, in the Sections 2.6. and 2.10, the competences of autonomous provinces are explained in details, 
as well as the jobs and the organization of administration in AP of Vojvodina, and it is stated in the Section 5.3.5. that regional authorities in the legal system of the Republic of Serbia are the authorities of AP of Vojvodina.

256. All the decisions adopted by the Assembly and the Government of the Autonomous Province of Vojvodina are translated and published in the Official Gazette of AP of Vojvodina, which is also published, in addition to Serbian language, in officially used minority languages at the bodies and organizations of AP of Vojvodina: Hungarian, Romanian, Ruthenian, Slovak and Croatian languages. Thanks to the Translation Pool, there is the possibility that all the documents made during the activities of the provincial authorities are translated into the above mentioned minority languages, thus also making the possibility to publish them. At the request of some provincial authority, the Translation Pool shall translate the required document, which is made available to the interested persons after it had been placed on the Internet page of the authority concerned. Many bulletins and publications of the Assembly of AP of Vojvodina and the Executive Council of AP of Vojvodina have also been translated. On the Internet page of the Provincial Secretariat for Regulations, Administration and National Communities, one may also review and take the documents of the Provincial Secretariat in Hungarian, Slovak, Romanian, Ruthenian and Croatian languages, in addition to Serbian language.

\subsubsection{Publishing of local documents in minority languages}

257. The statutes of the units of local self-government where minority languages are officially used also govern publishing of local municipal documents in official gazettes of the units of local self-government. The majority of the units of local self-government where some minority language is officially used have their own official gazettes, while a number of the units of local self-government utilize the services of publishing of their documents in the official gazettes of other units of local self-government. The Table below contains a review of publishing of local documents in adequate minority languages, prepared on the basis of information from all the units of local self-government where some of minority languages is officially used.

\begin{tabular}{|l|l|l|}
\hline Minority Language & Local Self-Government & Official Journal \\
\hline \multirow{4}{*}{ Albanian language } & Bujanovac & $\begin{array}{l}\text { The Official Gazette of the town } \\
\text { of Leskovac }\end{array}$ \\
\cline { 2 - 3 } & Medveđa & $\begin{array}{l}\text { The Official Gazette of the town } \\
\text { of Leskovac }\end{array}$ \\
\cline { 2 - 3 } & Preševo & $\begin{array}{l}\text { The Official Gazette of the town } \\
\text { of Leskovac }\end{array}$ \\
\hline \multirow{5}{*}{ Bosniak language } & Novi Pazar & Its own official journal \\
\cline { 2 - 3 } & Prijepolje & Its own official journal \\
\cline { 2 - 3 } & Sjenica & Its own official journal \\
\cline { 2 - 3 } & Tutin & Its own official journal \\
\hline & Ada & Its own official journal \\
\cline { 2 - 3 } & Bačka Topola & Its own official journal \\
\hline
\end{tabular}




\begin{tabular}{|l|l|l|}
\hline \multirow{5}{*}{ Hungarian language } & Bečej & Its own official journal \\
\cline { 2 - 3 } & Kanjiža & Its own official journal \\
\cline { 2 - 3 } & Kikinda & Its own official journal \\
\cline { 2 - 3 } & Kula & Its own official journal \\
\cline { 2 - 3 } & Mali Iđoš & Its own official journal \\
\cline { 2 - 3 } & Nova Crnja & Its own official journal \\
\cline { 2 - 3 } & Novi Kneževac & Its own official journal \\
\cline { 2 - 3 } & Senta & Its own official journal \\
\cline { 2 - 3 } & Sombor & Its own official journal \\
\cline { 2 - 3 } & Srbobran & Its own official journal \\
\cline { 2 - 3 } & Subotica & Its own official journal \\
\cline { 2 - 3 } & Temerin & Its own official journal \\
\cline { 2 - 3 } & Coka & Its own official journal \\
\hline Ruthenian language & Kula & Its own official journal \\
\hline Slovak language & BačKa Palanka & Its own official journal \\
\cline { 2 - 3 } & Bački Petrovac & Its own official journal \\
\hline Croatian language & Subotica & Its own official journal \\
\hline
\end{tabular}

258. Another form of affirmation of minority languages has been provided by Internet presentations, because many units of local self-government where minority languages are officially used also have presentations in minority languages. For example, the website of the municipality of Bujanovac also has a presentation in Albanian language, the website of the municipality of Bosilegrad has a presentation in Bulgarian language, and the websites of the town of Novi Pazar and the Municipality of Prijepolje are prepared in Latin script (the script of Bosniak language). After having an insight into the websites of units of local selfgovernment and the possibility of their use in minority languages, the Provincial Secretariat for Regulations, Administration and National Communities established that out of 31 local self-governments where Hungarian language and script are officially used, 10 websites are also prepared in this language. Out of 10 local self-governments where Romanian language and script are officially used , 1 website (the municipality of Alibunar) is prepared in this language, too. Out of 6 local self-governments where Ruthenian language and script are officially used, no website has been prepared in the language concerned. Out of 13 local selfgovernments where Slovak language and script are officially used, 3 websites (the municipalities of Alibunar, Bački Petrovac, Stara Pazova) have been prepared in this language, too. Out of 4 local self-governments where Croatian language and script are officially used, 1 website (the town of Subotica) has been prepared in this language, too. Czech language and script are only officially used in the municipality of Bela Crkva and the website is not prepared in this minority language.

\subsubsection{Use of traditional forms of place names in minority languages}

259. The Law on the National Councils of the National Minorities prescribes that traditional names of the units of local self-government, places and other geographic names in minority languages shall be used as to be established by the national council, if the language concerned is officially used in the territory of the unit of local self-government or place. Traditional names established by the 
national council become names officially used, in addition to names in Serbian language and are published in the Official Gazette of the Republic of Serbia and in the Official Gazette of the Autonomous Province of Vojvodina respectively, if the seat of the national council is in the territory of AP of Vojvodina.

260. The Section 5.3.7. of the First Periodic Report on the Implementation of the Charter contains the decisions on establishment of traditional names of towns, municipalities and places in Hungarian, Romanian, Ruthenian, Slovak languages, as well as of some places in Albanian and Bosniak languages. The following paragraphs of the Report contain traditional names of places in other minority languages, as well as the supplements to the decisions on establishment of traditional names for certain places where some of minority languages had been introduced into official use.

\section{Albanian language}

261. By decisions of the municipalities of Bujanovac, Medveđa and Preševo, where Albanian language is officially used, traditional names of places in Albanian had been established, as follows:

\begin{tabular}{|l|l|}
\hline $\begin{array}{l}\text { Name of Place in Serbian } \\
\text { Language }\end{array}$ & $\begin{array}{l}\text { Name of Place in } \\
\text { Albanian Language }\end{array}$ \\
\hline \multicolumn{2}{|c|}{ Municipality of Bujanovac } \\
\hline Бујановац & Bujanoc \\
\hline Велики Трновац & Tërrnoc \\
\hline Мали Трновац & Mal Tërrnoci \\
\hline Брезнице & Breznicë \\
\hline Ђорђевац & Gjergjec \\
\hline Муховац & Muhoc \\
\hline Равно Бучје & Ramabuçё \\
\hline Чар & Çarr \\
\hline Прибовце & Priboc \\
\hline Зарбинце & Zarbicë \\
\hline Сухарно & Suharnë \\
\hline Кончуљ & Konçul \\
\hline Добросин & Dobrosin \\
\hline Лучане & Lluçan \\
\hline Турија & Turi \\
\hline Осларе & Osllarë \\
\hline Несалце & Nesalcë \\
\hline Врбан & Vërban \\
\hline Грамада & Gramäё \\
\hline Г. Летовица & Letovica e Epërme \\
\hline Летовица & Letovicë \\
\hline & \\
& \\
\hline Медвеђа & Medvegjë \\
\hline
\end{tabular}




\begin{tabular}{|l|l|}
\hline Сијаринска бања & Banja e sijarinës \\
\hline Равна бања & Rama baja \\
\hline Тупале & Tupallë \\
\hline Капит & Kapit \\
\hline Свирце & Svircë \\
\hline \multicolumn{2}{|l|}{ Municipality of Preševo } \\
\multicolumn{2}{|l|}{} \\
\hline Прешево & Preshevë \\
\hline Рајинце & Raincë \\
\hline Г. Шушаја & Shoshaja e Epërme \\
\hline Буковац & Bukoc \\
\hline Мађере & Maxhere \\
\hline Госпођинце & Gosponicë \\
\hline Илинце & Ilincë \\
\hline Црнотинце & Corroticë \\
\hline Д. Шушаја & Shoshaja e Poshtme \\
\hline Букуревац & Bukuroc \\
\hline Ораовица & Rahovicë \\
\hline Бујић & Buhiq \\
\hline Курбалија & Kurbali \\
\hline Норча & Norçё \\
\hline Трнава & Tërrnavё \\
\hline Миратовац & Miratoc \\
\hline Чакановац & Cakanoc \\
\hline Чукарка & Çukarkё \\
\hline Жујинце & Zhunic \\
\hline Стрезовце & Strezoc \\
\hline Алиђерце & Geraj \\
\hline Големи Дол & Golemi doll \\
\hline Релан & Leran \\
\hline Буштрање & Bushtran \\
\hline Свињиште & Svinjishtё \\
\hline Славујевац & Bugarinë \\
\hline Љаник & Lanik \\
\hline
\end{tabular}

\section{Bosniak language}

262. In 2009 the National Council of the Bosniak National Minority adopted the Decision on establishment of traditional names of the units of local selfgovernment and places in the territories of Novi Pazar, Tutin, Sjenica and Prijepolje, where Bosniak language is officially used. Traditional names of the units of local self-government and dwelling areas in Bosniak language are:

Novi Pazar - dwelling areas: Haluloviće, Bajevica, Banja, Bare, Batajnik, Bjekova, Bijele Vode, Boturovina, Brđani, Brestovo, Varevo, Vjever, Vidovo, Vitkoviće, Vojkoviće, Vojniće, Vranovina, Vučiniće, Vučija Lokva, Golice, Gornja Tušimlja, Goševo, Građanoviće, Gračane, Grubetiće, Deževa, Dojinoviće, Dolac, Doljani, Dragočevo, Dramiće, Žunjeviće, Zabrđe, Zlatare, Ivanča, Izbice, Jablanica, Javor, Janča, Joha, Kašalj, Kovačevo, Kožlje, Koprivica, Kosuriće, Kruševo, Kuzmičevo, Leča, Lopuzinje, Lukare, Lukarsko Goševo, Lukocrijevo, 
Miščiće, Mur, Muhovo, Negotinac, Odojeviće, Okose, Osaonica, Osoje, Oholje, Pavlje, Pasji Potok, Pilorete, Pobrđe, Požega, Požežina, Polokce, Pope, Postijenje, Prćenova, Pusta Tušimlja, Pustovlah, Radaljica, Rajetiće, Rajkoviće, Rajčinoviće, Rajčinovićka Trnava, Rakovac, Rast, Sebečevo, Sitniče, Skukovo, Slatina, Smilov Laz, Srednja Tušimlja, Stradovo, Sudsko Selo, Tenkovo, Trnava, Tunovo, Hotkovo, Cokoviće, Čašić Dolac, Šavci, Šaronje, Štitare;

Prijepolje - naseljena mjesta: Haljinovići, Balići, Bare, Biskupići, Bjelahova, Brajkovac, Brvine, Brodarevo, Bukovik, Vinicka, Vrbovo, Gojakoviće, Gornje Babine, Gornje Goračići, Gornji Stranjani, Gostun, Gračanica, Grobnice, Divci, Donje Babine, Donji Stranjani, Drenova, Dušmanići, Đurašići, Zabrnji Toci, Zavinograđe, Zalug, Zastup, Zvijezd, Ivanje, Ivezići, Izbičanj, Jabuka, Junčevići, Kamena Gora, Karaula, Karoševina, Kaćevo, Kašice, Kovačevac, Koprivna, Kosatica, Koševine, Kruševo, Kučin, Lučice, Mataruge, Međani, Mijani, Mijoska, Milakovići, Mileševo, Milošev Dol, Miljevići, Mrčkovina, Muškovina, Orovac, Orašac, Osoje, Oštra Stijena, Potkrš, Potok, Pravoševa, Pranjci, Rasno, Ratajska, Sedobro, Seljane, Seljašnica, Skokuće, Slatina, Sopotnica, Taševo, Hisardžik, Hrta, Crkveni Toci, Čadinje, Čauševići, Džurovo;

Sjenica - dwelling areas: Aliveroviće, Bagačiće, Bare, Bačija, Bioc, Blato, Boguti, Boljare, Borišiće, Boroviće, Breza, Brnjica, Buđevo, Vapa, Veskoviće, Visočka, Višnjeva, Višnjice, Vrapci, Vrbnica, Vrhsjenice, Goluban, Gonje, Gornje Lopiže, Goševo, Grabovica, Gradac, Grgaje, Doliće, Donje Goračice, Donje Lopiže, Dragojloviće, Draževiće, Družiniće, Dubnica, Duga Poljana, Dujke, Dunišiće, Žabren, Žitniće, Zabrđe, Zaječiće, Zahumsko, Jevik, Jezero, Kalipolje, Kamešnica, Kanjevina, Karajukića Bunari, Kijevce, Kladnica, Kneževac, Koznik, Kokošiće, Krajinoviće, Krivaja, Krnja Jela, Krstac, Krće, Lijeva Rijeka, Ljutaje, Mašoviće, Medare, Međugor, Milići, Papiće, Petrovo Polje, Plana, Poda, Ponorac, Pralja, Raždaginja, Rasno, Raspoganče, Rastenoviće, Raškoviće, Skradnik, Strahiniće, Stup, Sugubine, Sušica, Crešnjevica, Trijebine, Tuzinje, Tutiće, Uvac, Ugao, Ursule, Ušak, Fijulje, Caričina, Cetanoviće, Crvsko, Crčevo, Čedovo, Čipalje, Čitluk, Šare, Štavalj, Šušure;

Tutin - dwelling areas: Harapoviće, Baljen, Batrage, Baćica, Bijohane, Blace, Bovanj, Boroštica, Braćak, Bregove, Brniševo, Bujkoviće, Velje Polje, Veseniće, Vrapče, Vrba, Glogovik, Gluhavica, Gnjila, Godovo, Gornji Crniš, Gradac, Gujiće, Gurdijelje, Guceviće, Devreče, Delimeđe, Detane, Dobri Dub, Dobrinje, Dolovo, Draga, Dubovo, Dulebe, Đerekare, Ervenice, Žirče, Župa, Žuče, Zapadni Mojstir, Izrok, Istočni Mojstir, Jablanica, Jerebica, Jezgroviće, Jeliće, Južni Kočarnik, Kovače, Koniče, Ljeskova, Lipica, Lukavica, Melaje, Mitrova, Morani, Naboje, Nadumce, Namga, Noćaje, Oraše, Orlje, Ostrovica, Paljevo, Piskopovce, Plenibabe, Pokrvenik, Pope, Popiće, Potrijeb, Pružanj, Raduhovce, Raduša, Ramoševo, Reževiće, Ribariće, Rudnica, Ruđe, Saš, Sjeverni Kočarnik, Smoluća, Starčeviće, Strumce, Suhodo, Točilovo, Čulije, Kadiluk, Čarovina, Čmanjke, Čukote, Šaronje, Šipče, Špiljane.

\section{Bulgarian language}


263. Bulgarian language and script are officially used in the municipalities of Bosilegrad and Dimitrovgrad, and since 2008 it has also been introduced into official use in the territory of the dwelling area of Ivanovo according to the statute of the town of Pančevo. The National Council of the Bulgarian National Minority submitted a request to the assembly of the municipality of Dimitrovgrad to return previously used names in the territory of this municipality, but this request has not been resolved yet. Upon the resolution of the request, the national Council shall adopt the decision on establishment of traditional names of towns, municipalities and places in Bulgarian language.

\section{Hungarian language}

264. The decision on establishment of names of places in Vojvodina in Hungarian language provided a list of traditional names of places in this language in the territory of 28 local self-governments, in 288 places. After the first cycle of monitoring of the implementation of the Charter, certain local self-governments established new places in the territories of which Hungarian language had been introduced into official use, too. For those places, the National Council of the Hungarian National Minority established the following traditional names:

\begin{tabular}{|l|l|l|}
\hline $\begin{array}{l}\text { Name of Place in } \\
\text { Serbian Language }\end{array}$ & $\begin{array}{l}\text { Name of Place in } \\
\text { Hungarian Language }\end{array}$ & Municipality/Town \\
\hline Купусина & Kupuszina & Apatin \\
\hline Свилојево & Sílagy & Apatin \\
\hline Карађорђево & Karađorđevo & Bас̌ка Topola \\
\hline Његошево & Njegoševo & Bас̌ка Topola \\
\hline Томиславци & Tomislavci & Вас̌ка Topola \\
\hline Победа & Pobeda & Bас̌ка Topola \\
\hline Светићево & Svetićevo & Bас̌ка Topola \\
\hline Сутјеска & Sarcia & Sečanj \\
\hline Иваново & Sándoregyháza & Pančevo \\
\hline
\end{tabular}

\section{Romanian language}

265. The National Council of the Romanian National Minority established 38 traditional names of towns, municipalities and dwelling areas in Romanian language. After the first cycle of monitoring of the implementation of the Charter, traditional names of dwelling areas in Romanian language were established for the following places:

\begin{tabular}{|l|l|l|}
\hline $\begin{array}{l}\text { Name of Place in } \\
\text { Serbian Language }\end{array}$ & $\begin{array}{l}\text { Name of Place in } \\
\text { Romanian Language }\end{array}$ & Municipality \\
\hline Житиште & Jitişte & Žitište \\
\hline Банатски Двор & Banatski Dvor & Žitište \\
\hline Банатско Вишњићево & Banatsko Višnjićevo & Žitište \\
\hline Банатско Карађорђево & Bantsko Karadjordjevo & Žitište \\
\hline Међа & Međa & Žitište \\
\hline Нови Итебеј & Novi Itebej & Žitište \\
\hline
\end{tabular}




\begin{tabular}{|l|l|l|}
\hline Равни Тополовац & Ravni Topolovac & Žitište \\
\hline Српски Итебеј & Srpski Itebej & Žitište \\
\hline Торда & Torda & Žitište \\
\hline Хетин & Hetin & Žitište \\
\hline Честерег & Čestereg & Žitište \\
\hline
\end{tabular}

\section{Slovak language}

266. The initial decision established traditional names for 30 towns, municipalities and dwelling places in Slovak language. The supplement to this decision established traditional names for another 22 dwelling places in the territory of the municipalities of Вас̌ка Palanka and Вас̌ка Topola in Slovak language, as follows:

\begin{tabular}{|c|c|c|}
\hline $\begin{array}{l}\text { Name of Place in } \\
\text { Serbian Language }\end{array}$ & $\begin{array}{l}\text { Name of Place in } \\
\text { Slovak Language }\end{array}$ & Municipality \\
\hline Багремово & Bagremovo & Вас̌ка Palanka \\
\hline Bačka Topola & Báčska Topol'a & Вас̌ка Topola \\
\hline Вас̌ки Соколац & Báčsky Sokolac & Вас̌ка Topola \\
\hline Богарош & Bogaroš & Вас̌ка Topola \\
\hline Горња Рогатица & Gornja Rogatica & Вас̌ка Topola \\
\hline Гунарош & Gunaroš & Вас̌ка Palanka \\
\hline Зобнатица & Zobnatica & Вас̌ка Topola \\
\hline Карађорђево & Karađorđevo & Вас̌ка Topola \\
\hline Кавило & Kavilo & Вас̌ка Topola \\
\hline Криваја & Krivaja & Вас̌ка Topola \\
\hline Мали Београд & Malý Belehrad & Вас̌ка Palanka \\
\hline Мићуново & Mićunovo & Вас̌ка Topola \\
\hline Ново Орахово & Novo Orahovo & Вас̌ка Topola \\
\hline Његошево & Njegoševo & Вас̌ка Topola \\
\hline Оборњача & Obornjača & Вас̌ка Topola \\
\hline Томиславци & Tomislavci & Вас̌ка Topola \\
\hline Панонија & Panónia & Вас̌ка Topola \\
\hline Пачир & Pačir & Вас̌ка Palanka \\
\hline Победа & Pobeda & Вас̌ка Topola \\
\hline Светићево & Svetićevo & Вас̌ка Topola \\
\hline Средњи Салаш & Srednji Salaš & Вас̌ка Topola \\
\hline Стара Моравица & Stara Moravica & Вас̌ка Topola \\
\hline
\end{tabular}

\section{Croatian language}

267. In the course of 2009, the National Council of the Croatian National Minority established a list of 8 traditional names of dwelling places in Croatian language in 5 municipalities, as follows:

\begin{tabular}{|l|l|l|}
\hline $\begin{array}{l}\text { Name of Place in } \\
\text { Serbian Language }\end{array}$ & $\begin{array}{l}\text { Name of Place in } \\
\text { Croatian Language }\end{array}$ & Town/Municipality \\
\hline Бајмок & Bajmak & Subotica \\
\hline Љутово & Mirgeš & Subotica \\
\hline Стари Жедник & Žednik & Subotica \\
\hline
\end{tabular}




\begin{tabular}{|l|l|l|}
\hline Сонта & Sonta & Apatin \\
\hline Вас̌ки брег & Bereg & Sombor \\
\hline Вас̌ки Моноштор & Monoštor & Sombor \\
\hline Стара Бингула & Stara Bingula & Sremska Mitrovica \\
\hline Сот & Sot & Šid \\
\hline
\end{tabular}

268. It was concluded from the consultations with the representatives of the national councils of speakers of Romani and Ukrainian languages that there are no traditional names of places in the languages concerned in the territory of the Republic of Serbia, since the subject national minorities do not live in larger numbers in certain territories and dwelling places so that their names could be established and accepted. The speakers of Ukrainian language use Serbian names for towns, which are phonetically modified (and sound like Ukrainian names), such as: Beljhorod - Belrgade, Novi Sad - Novej Sad, Sremska Mitrovica Сремска Метровеца, Vrbas - Вербас, etc.

\subsubsection{Submission of applications to public services in minority languages}

269. The Section 5.3.8. of the First Periodic Report on the Implementation of the Charter contains the information about the status of public services in the legal system of the Republic of Serbia and the legislative framework of their activities. As mentioned, the Law on Public Services does not contain any explicit provision on the language the citizens may use to apply to public services in order to accomplish their rights and obligations, however, bearing in mind that public services, when deciding on the rights and obligations of citizens, organizations, namely uses of their services and when performing other jobs established by law, shall decide and act pursuant to the Law on General Administrative Procedure and the Law on Official Use of Language and Script, which means that oral and written applications may also be submitted in minority languages.

270. According to the information obtained from the Elektroprivreda Srbije Public Company, at this company and its dependant companies, there are no special regulations concerning the use of minority languages on the occasion of submission of applications by parties, but there are no limitations of any kind, either, to submit applications in the languages concerned. For example, although the documents on internal organization and systematization do not prescribe a condition of knowledge of some minority language for employees of public companies doing business in the territory of AP of Vojvodina, the Elektroprivreda Public Company and the Panonske termoelektrane - toplane Public Company, in which territory some minority language is used, have an option to provide written and oral communications in minority language concerned. No applications in any of minority languages were submitted to this public company by parties. Also, the Telekom Srbija Communication Company received no applications in minority languages. However, should they be submitted, they will be processed according to the legal regulations. If Telekom receives any applications in some minority language, it shall not be a problem to act accordingly. The Srbija PTT Communication Public Company ensures the implementation of legal regulations 
in the official use of minority languages in the territory of its postal communication units where some minority language and script are officially used, such as the postal communication units of Subotica, Sombor, Kikinda, etc.

271. According to the information of the Provincial Secretariat for Regulations, Administration and National Communities of AP of Vojvodina, the bodies, institutions and companies rendering the services and collecting the payments for the services from citizens in the field of electric power industry, sales of natural gas, utilities, post and telegraph, insufficiently accept the positive effects of the decision on precise establishment of certain issues of official use of language and script of national minorities in the territory of AP of Vojvodina, primarily in promotion and presentation of the services they render, by writing them in the officially used languages of national minorities in the territories concerned. The discussions have been held and the supervision has been provided for a certain number of providers of such services and by a relevant decision they were ordered to act accordingly within a specified term. In spite of several interventions and 12 issued decisions to the supervised companies, not much has been done concerning the official use of languages and scripts of national minorities with the Serbian Railways Public Company in the territory of AP of Vojvodina, because the names of places, timetable, announcements of arrivals and departures of trains and the main information on platforms and premises are only written in Serbian language and not in the officially used minority languages. In respect of the decisions related to the railway stations of Bačka Topola, Vrbas, Kisač, Senta and Subotica, appeals had been filed, which were dismissed as groundless in the second instance proceedings. The Serbian Railways Public Company initiated administrative proceedings before the District Court in Novi Sad against these decisions, which became final. Deciding upon the actions, the District Court adopted judgements dismissing all individual actions as groundless, thus also upholding all the decisions of the Provincial Secretariat for Regulations, Administration and National Communities. In subsequent contacts with the authorised representatives and managers of the Serbian Railways Public Company, it was stressed that this company is obliged to act according to final court judgements and a term was fixed for this company to act voluntarily. Upon the expiration of the fixed term, the provincial authority intends to initiate the procedure of forced enforcement. In respect of various information delivered to customers, which are usually written or printed in Serbian language and in officially used minority language in the community concerned, the state of affairs is much better. This primarily refers to the post offices of the Srbija PTT Communication Public Company, counters of the Elektroprivreda Srbije Public Company where the information to customers have been lately written in minority languages, too. There is an increasing number of public companies rendering utility services, which now issues bills and various information to citizens in the minority language officially used in their territory.

272. Based on the information received from the units of local self government, which accepted to participate in the preparation of this Report, bills, receipts and 
information in minority languages are issued by the public companies (electricity bills, utility services and postal and telephone bills) in the following towns and municipalities: Ada (Hungarian language), Bečej (Hungarian language), Bačka Topola (Hungarian language), Preševo (Albanian language), Senta (Hungarian language), Subotica (Hungarian and Croatian languages), Temerin (Hungarian language) and Čoka (Hungarian language). In the territory of the town of Subotica and in the municipalities of Apatin and Kanjiža, the public utility companies founded by the town or by the assembly of the municipality issue receipts and information in the minority language officially used in their territory, while the bills are issued in Serbian language.

\subsubsection{Engagement of speakers of minority languages in public services}

273. The regulations of the Republic of Serbia, as already said ensure the use of minority languages in the operations of public services, too, which directly indicates the engagement of speakers of minority languages in public services. There are no precise data about the number of engaged speakers of minority languages in public services because, for example, the public companies that accepted to participate in the preparation of this Report, do not contain in their internal documents on organization and systematization of jobs in the territories in which minority languages are also in official use, the provisions concerning positions which require the knowledge of minority languages. The Telekom announced the preparation of the internal document to govern the scope and method of application of the constitutional and legal provisions concerning the use of minority languages and script at the company level in order to regulate this issue in a uniform way.

\subsubsection{Use and adoption of family names in minority languages}

274. The Section 5.3.10. of the First Periodic Report on the Implementation of the Charter contains the relevant regulations governing the issue of use of family names in minority languages. After the first cycle of monitoring of the implementation of the Charter, the new Law on Registry Books was adopted in 2009, which governs the issue of entering personal names of the members of national minorities in registry books, as the basic official records on the personal status of citizens. The certificates from the registry books are issued on the basis of the data contained in the integral texts of registry books, namely, the certificates contain the latest data entered in the registry books until the time of issuance of certificates, thus also containing the data about personal names. Bylaws necessary for its implementation were adopted on the grounds of this Law. Among other documents, the instructions concerning keeping of registry books and forms of registry books were also adopted, which prescribe the method of issuance of certificates from the registry books and the forms of the certificates from the registry books. In this respect it is to be stressed in particular that this is for the first time to define the appearance and the contents of the forms of the certificates from the registry books in minority language and script. Namely, item 
137 of these instructions prescribe that the names of the columns of the certificates from the registry books may also be printed in minority language and script at the back of the forms of the certificates from the registry books. If there are several officially used national minority languages, the text in the languages concerned is written according to the alphabetic order. The administrative bodies, which provide keeping of registry books pursuant to Article 6 of the Law on Registry Books, have been issuing the certificates from the registry books in the forms prescribed by the instructions since 1 March 2010.

275. As mentioned in the Section 2.1.1. of the Report, the amendments and supplements of the Law on the Official Use of Language and Script added new Article 18a. This provision prescribes that the members of national minorities have the right to free choice and use of personal names of their children, as well as to enter these personal names in all public documents, official records and personal data bases according to the orthography of minority languages too, which does not exclude that personal names are also parallelly written according to Serbian orthography and script. The decision on precise regulation of certain issues on official use of national minorities language and script in the territory of AP of Vojvodina also prescribes that a member of the national minority has the right to enter his/her personal name and personal name of his/her children into the registry books in their original form in script and according to orthography of the language concerned. The decision on multilingual forms of certificates from the registry books and entries in the same books enable the administration in the units of local self-governments where minority language is also officially used, to issue a certificate from the registry books in bilingual forms, if required, and in the way it had been originally entered in the registry books. If some personal name is only entered in the registry books in Serbian language the registrar will instruct the client how to request that his/her personal name is also entered in the registry book in the original way after the relevant administrative had been conducted.

276. According to the data of the Provincial Secretariat for Regulations, Administration and National Communities in 2009 there were 52 administrative proceedings for the amendment of personal names into minority languages officially used. All 52 proceedings were conducted in Serbian and Hungarian languages, namely, 172 administrative proceedings for the amendment of personal names. In percentage, the largest number of proceedings for the amendment of personal names, comparing the number of proceedings in minority language with the total number of proceedings, was conducted in the municipality of Kanjiža where, out of 52 applications in total, the proceedings were held in Serbian and Hungarian languages in 38 cases, in the municipality of Bečej where, out of 28 applications in total, 10 proceedings were held in Serbian and Hungarian languages and in the municipality of Temerin where, out of 32 applications in total, 4 proceedings were held in Serbian and Hungarian languages. In the proceedings for the amendment of the entry of personal names in registry books in the course of 2009, in 125 cases (323 cases in the course of 2008), the proceedings were held in minority languages, to be more precise in Serbian and 
Hungarian languages. In percentage, the largest number of proceedings for the amendment of entry of personal names in minority languages was conducted in the municipalities of Bačka Topola, Kanjiža, Kovin, Kula, Novi Bečej and towns of Zrenjanin and Subotica. In the proceedings for the correction of entry of personal names in the registry books, 184 proceedings in minority languages were held in 2009 (33 proceedings in the course of 2008) and these proceedings were the first instance administrative proceedings for the corrections of entries in the registry books. All 184 proceedings were held in Serbian and Hungarian languages.

\subsubsection{Activities for the implementation of box-recommendations of the Committee of Experts concerning Article 10 of the Charter}

277. In the Report on the Implementation of the Charter in the first reporting cycle, the Committee of Experts established two box-recommendations concerning Article 10 of the Charter. The following paragraphs contain information on the activities undertaken by the state for the purpose of its implementation.

\subsubsection{Activities to ensure submission of oral and written applications to State authorities in minority languages}

The Committee of Experts encourages the Serbian authorities to take the necessary legal and practical measures to ensure that users of regional or minority languages may submit oral or written applications in these languages to State authorities.

278. It is stated in the Section 4.3.1. of the Report that after the first cycle of monitoring of the implementation of the Charter, the amendment of legal regulations enabled the users of minority languages to submit applications to the State authorities in their languages. Namely, Article 11 paragraph 8 of the Law on Official Use of Language and Script prescribes that the members of national minorities the number of which does not reach $2 \%$ in the total population of the Republic of Serbia according to the last census, may submit applications to the republic authorities in their language and that they have the right to receive a reply in the language concerned through the unit of local self-government where the language of the national minority concerned is officially used, whereas the unit of local self-government will arrange a translation and cover the costs of the translation of the letter addressed to the republic authority and of its reply. It practically means that the users of all officially used minority languages in the units of local self-government have an option to submit applications to the State authorities and receive replies from them in their language.

\subsubsection{Activities to ensure the publication of official documents in minority languages}

The Committee of Experts encourages the Serbian authorities to take the 
necessary organisational measures to ensure the publication by local authorities of their official documents also in relevant regional or minority languages.

279. Since the State leaves to the units of local self-government to establish the minority languages in official use in their territories, the State approves and encourages local authorities to publish the documents in minority languages. However, as already said, the units of local self-government ensuring the right to official use of minority language, have increased costs also relating to translations or to installation of adequate computer programmes, requiring that their financing is resolved as a system. The adoption of the Law on Maximum Number of Employees in Local Administration, which prescribes that on the occasion of establishment of the required number of employees at the bodies of local selfgovernment special requirements in respect of the need for translators in local self-governments where several minority languages are officially used, may also be considered a form of support by the State to the units of local self-government in, inter alia, their efforts to ensure the publishing of their official documents in the relevant minority languages. 
4.4.

Article 11

Media

\section{Selected paragraphs and sub-paragraphs}

1. The Parties undertake, for the users of the regional or minority languages within the territories in which those languages are spoken, according to the situation of each language, to the extent that the public authorities, directly or indirectly, are competent, have power or play a role in this field, and respecting the principle of the independence and autonomy of the media:

a)

to the extent that radio and television carry out a public service mission:

(iii) to make adequate provision so that broadcasters offer programmes in the regional or minority languages;

b)

(ii) to encourage and/or facilitate the broadcasting of radio programmes in the regional or minority languages on a magistrate basis;

c)

(ii) to encourage and/or facilitate the broadcasting of television programmes in the regional or minority languages on a magistrate basis;

d) to encourage and/or facilitate the production and distribution of audio and audiovisual works in the regional or minority languages;

e)

(i) to encourage and/or facilitate the creation and/or maintenance of at least one newspaper in the regional or minority languages; or

\section{f)}

(ii) to apply existing measures for financial assistance also to audiovisual productions in the regional or minority languages;

2. The Parties undertake to guarantee freedom of direct reception of radio and television broadcasts from neighbouring countries in a language used in identical or similar form to a regional or minority language, and not to oppose the retransmission of radio and television broadcasts from neighbouring countries in such a language. They further undertake to ensure that no restrictions will be placed on the freedom of expression and free circulation of information in the written press in a language used in identical or similar form to a regional or minority language. The exercise of the abovementioned freedoms, since it carries with it duties and responsibilities, may be subject to such formalities, conditions, restrictions or penalties as are prescribed by law and are necessary in a democratic society, in the interests of national security, territorial integrity or public safety, for the prevention of disorder or crime, for the protection of health or morals, for the protection of the reputation or rights of others, for preventing disclosure of information received in confidence, or for maintaining the authority and impartiality of the judiciary. 
3. The Parties undertake to ensure that the interests of the users of regional or minority languages are represented or taken into account within such bodies as may be established in accordance with the law with responsibility for guaranteeing the freedom and pluralism of the media.

\subsubsection{Novelties after the first cycle of monitoring of the implementation of the Charter}

\subsubsection{Broadcasting licences for radio and TV programmes}

280. Pursuant to the Law on Broadcasting and the Distribution Schedule of Radio Frequencies, since 2006 the Republic Radio-Broadcasting Agency has started the process of issuance of licences for broadcasting of programmes by electronic media for the territory of entire Republic of Serbia, regional and local areas. The process of issuance of licences implies a compulsory public tender, which is issued when on the grounds of the Distribution Schedule of Radio Frequencies there are possibilities to issue new licences for programme broadcasting. In 2007 the first tenders for broadcasting of programmes for local areas were issued. The broadcaster - radio and television stations from local areas, especially from nationally mixed environments, play a very important role in information to be rendered to the members of national minorities, namely of users of minority languages. Based on the procedure prescribed by law, the Republic RadioBroadcasting Agency adopts a decision on issuance of licence for broadcasting of programmes in accordance with the established criteria and prescribed conditions and standards for production and broadcasting of programmes. The licence to run a radio-broadcasting station is an integral part of the licence for programme broadcasting, which is issued by the Republic Telecommunication Agency (RATEL) pursuant to the procedure established by law. The registry of issued licences for broadcasting of TV/radio programmes is kept and this registry is public. The registry of issued licences may also be accessed on the official website of the Republic Radio-Broadcasting Agency and it is regularly updated in accordance with the decisions of the Council of the Republic Radio-Broadcasting Agency. Since the registry of issued licences for broadcasting of TV/radio programmes does not include special records of radio and television stations broadcasting programmes in minority languages, for the requirements of this Report, the Republic Radio-Broadcasting Agency prepared a list of radio and television stations broadcasting programmes in minority languages after a review of the tender documentation for the issuance of licences for broadcasting of programmes. Based on the programme studies by the applicants to the tender, it was found that programmes in Albanian language are broadcasted by three radio and three TV stations, one radio and one TV station in Bosniak language, three radio and two TV stations in Bulgarian language, 24 radio and $8 \mathrm{TV}$ stations in Hungarian language, 20 radio and $7 \mathrm{TV}$ stations in Romani language, 9 radio and 3 TV stations in Romanian language, 10 radio and one TV station in Ruthenian language, 20 radio and $5 \mathrm{TV}$ stations in Slovak language, 7 radio stations in 
Ukrainian language and 9 radio stations in Croatian language. The above mentioned numbers do not present the factual status of the number of radio and television stations broadcasting programs in minority languages because many applicants to the public tender stated in their program studies that they were going to broadcast programs in minority languages as well during the validity of the licence for program broadcasting.

\subsubsection{Measures for resolution of media issues}

281. Within the limits of financial capabilities, the activities are being undertaken in the republic of Serbia to resolve the issue of lack of financial resources, qualified journalists and modern equipment for the media broadcasting or publishing programs in minority languages, the following paragraphs contain some examples of such measures.

282. The Ministry of Culture - the Media Sector, through tenders for co-financing of media and productions in minority languages, also grants funds to the projects aimed at technical improvement, professional advancement and engagement of young journalists, expansion of network of reporters, initiation of Internet presentations, special editorial offices and programs in minority languages, etc. In 2007, 2,612,000.00 dinars (9 projects) were allocated for these purposes out of the total budget of 11,500,000.00 dinars, and in 2008, 2,600,000.00 dinars (9 projects) out of the total budget of $24,700,000.00$ dinars. A considerably smaller number of projects was received for the tender in 2009, so the funds were allocated to two projects only in the total amount of 528,000.00 dinars.

283. Under the initiative of the Ministry of Culture, the Government of the Republic of Serbia adopted the conclusion on measures for assistance to media under the circumstances of the economic crisis. One of these measures was financial support to media distributed within the framework of the tender for co-financing of projects/programs in the field of public information issued in August 2009. Out of the total sum of $80,000,000.00$ dinars, the amount of 11,300,000.00 dinars was allocated to the productions and projects in minority languages.

284. The Ministry of Culture - the Media Sector also granted funds to individual projects in order to help some media and institutions of importance for the improvement of information in minority languages overcome the current financial and personnel problems and to improve professional standards. Accordingly in 2007 the Research Centre for Ethnicities was granted 200,000.00 dinars for the project of Training of Media Representatives in Accomplishment of Rights of National Minorities in Serbia and Opportunities for Advancement, 200.000,00 dinars to Radio Srbobran for bilingual programs (Serbian-Hungarian) on culture, art and media, as well as 736,800.00 dinars to the Beta Press Newspaper Agency for news in minority languages. In 2008, due to financial difficulties, three electronic media broadcasting programs in minority languages referred to the Ministry of Culture - the RTV Nišava (Romani), the Niš Radio Rom (Romani), 
Obrenovac and Radio Ema (Romani), Bujanovac. They were granted almost 300,000.00 dinars for the preparation of technical documentation required for the provision of a licence from the RATEL, being a condition for program broadcasting. The Ministry of Culture helped the same year the Romano Nevipe, Romani newspaper, with 960,000.00 dinars to improve and expand its network of reporters, engaging young and educated Roma interested in journalism. Assessing its extremely difficult financial status, as well as its incapability to resolve aggravated technical problems on its own (obsolete equipment), in 2009 the Ministry of Culture granted 2,100.000.00 dinars to the Nezavisna televizija from Niš to improve technical capacities.

285. In co-operation with the Ministry of Human and Minority Rights and the National Council of the Romani National Minority, the Ministry of Culture started the implementation of the project of engagement of Romani representatives in media . The project included 18 attendees of training for Romani representatives in media, which is performed for one representative in each of 16 towns in Serbia and for two representatives in Belgrade. Upon the completion of training, which has two stages, Romani representatives in media will be engaged in local communities to edit programmes and place information of importance for the Romani community through local media. For this purpose the Ministry of Culture allocated over $1,000,000.00$ dinars.

286. The Provincial Secretariat of Information of AP of Vojvodina is engaged in the resolution of financial difficulties of minority media. In addition to subsidies to Magyar Szó, daily in Hungarian language, another 6,000,000.00 dinars have been allocated to resolve the difficulties faced by the printing unit belonging to the same company.

287. Since 2009 the Provincial Secretariat for Information of AP of Vojvodina has been granting scholarship to the students of all media professions and other professions required by the public media in order to improve their personnel structure. Unfortunately, although 42 scholarships were foreseen, only seven media applied to the tender, and the tender requirements were met by three students only, of whom for one student the job is secured by the Hrvatska riječ, a weekly in Croatian language. The amount of scholarship is 7,000 dinars monthly.

\subsubsection{Public broadcasting agencies}

288. The following republic and provincial radio-broadcasting institutions are responsible for the radio-broadcasting service in the Republic of Serbia: the Public Radio-Broadcasting Agency of Serbia and the Public Radio-Broadcasting Agency of Vojvodina. These very public radio-broadcasting agencies have a primary role in respect of the development of program diversities in order to affirm plural identities. This for the reason that the provisions of the Law o Broadcasting prescribe special obligations of public radio-broadcasting agencies in respect of achievement of general interest in the sphere of quality and program 
diversities, and thus also the obligations concerning the accomplishment of interests of minority groups to preserve their identities.

289. Article 77 paragraph 3 of the Law on Broadcasting establishes that the programs produced and broadcasted within the framework of public radio-broadcasting agency must ensure diversity and balance of contents (mutual conformity or compliance), which support democratic values of a modern society and in particular the respect for human rights and cultural, national, ethnic and political pluralism of ideas and opinions. The provisions of Article 78 items 2, 3 and 4 of the same Law prescribe that the public radio-broadcasting agencies are obliged to produce and broadcast programmes intended for all segments of the society, without any discrimination, taking particular care of specific social groups, such as, inter alia, minority and ethnic groups, to comply with linguistic and speech standards of both majority population and of national minorities, to an adequate extent, namely of ethnic groups in the territories where the programmes are broadcasted and to meet the requirements of citizens related to programme contents expressing cultural identity of both the nations and the national minorities and ethnic groups respectively, providing them a possibility to watch and listen to certain programmes in their mother tongue and script in the territories where they live and work.

290. The Department of Supervision and Analysis of the Republic Broadcasting Agency controls the programmes of the public radio-broadcasting agencies related to the mentioned article of the Law on Broadcasting, which was the ground to establish programmes intended to specific social groups, including minority and ethnic groups as well.

291. Within the framework of the Public Radio-Broadcasting Agency of Serbia Radio Belgrade, there is an editorial office in Romani language broadcasting daily programmes mainly in Romani language in the duration of 30 minutes. Television Belgrade has no special editorial offices producing programmes in minority languages. However, within the period from 2007-2009 and within the framework of the first and the second channel of the RTS, 3,475 programmes in minority languages were broadcasted, which in the terms of the duration of broadcasted programmes amounts to 48,134 minutes, namely 33.4 days. The Gradanin, programme dedicated to the members of national minorities in Serbia (education, employment, participation in public life, cultural events, customs, multi-ethnic projects, issues of re-admission...) has been produced and broadcasted once a week. Depending on the interlocutor's wish, mother tongue or minority language (Albanian, Bulgarian, Hungarian, Macedonian, Romani, Romanian, Slovak, Croatian...) or Serbian language may be used.

292. Within the framework of the Public Radio-Broadcasting Agency of Vojvodina, one channel, Radio-Television of Vojvodina 2 (RTV2) broadcasts programmes intended to the users of the minority languages. Radio Novi Sad broadcasts programmes in eight minority languages and Television of Vojvodina broadcasts 
programmes in nine minority languages. $T V$ Vojvodina broadcasts programmes in ten languages (including Serbian language as well) and the joint programme of 30 minutes under the title of Zajedno, once a week.

293. The data on the duration of radio and television programmes on RTV Vojvodina in minority languages are presented in the table below.

\begin{tabular}{|c|c|}
\hline $\begin{array}{c}\text { Radio Programme } \\
\text { Broadcasting Language }\end{array}$ & Programme Duration \\
\hline Hungarian language & 24 hours daily \\
\hline Romani language & 1 hour daily \\
\hline Romanian language & 5 hours daily \\
\hline Ruthenian language & 5 hours daily \\
\hline Slovak language & 5 hours daily \\
\hline Ukrainian language & 15 minutes daily +1 hour weekly \\
\hline Bunjevac speech & 0.5 hour weekly \\
\hline Macedonian language & 0.5 hour weekly \\
\hline
\end{tabular}

\begin{tabular}{|c|c|}
\hline $\begin{array}{c}\text { Television Programme } \\
\text { Broadcasting Languages }\end{array}$ & Programme Duration \\
\hline Hungarian language & $\begin{array}{l}\text { In average } 2.9 \text { hours daily, namely } 64 \text { hours monthly premier and } \\
\text { reply programmes ( } 45 \text { minutes daily }+3 \text { hours on Mondays and } \\
\text { Saturdays }+2 \text { hours on Sundays }+ \text { once monthly: } 1.5 \text { hours of family } \\
\text { magazine and } 0,5 \text { hour of children's programme }+ \text { twice a month } \\
0.5 \text { hour of programme for Diaspora and entrepreneurs). }\end{array}$ \\
\hline Romani language & $\begin{array}{l}\text { In average } 1 \text { hour daily, namely } 58 \text { hours monthly of premier and } \\
\text { replay programmes ( } 10 \text { minutes of daily information programmes }+ \\
\text { weekly: } 1.5 \text { hours of information-political and cultural programmes } \\
\text { and } 1 \text { hour of magazine }+1.5 \text { hours monthly of family magazine). }\end{array}$ \\
\hline Romanian language & $\begin{array}{l}\text { In average } 1 \text { hour daily, namely } 58 \text { hours monthly of premier and } \\
\text { replay programmes ( } 10 \text { minutes of daily information programmes }+ \\
\text { weekly: } 1.5 \text { hours of information-political and cultural programmes } \\
\text { and } 1 \text { hour of magazine }+1.5 \text { hours monthly of family magazine). }\end{array}$ \\
\hline Ruthenian language & $\begin{array}{l}\text { In average } 1 \text { hour daily, namely } 58 \text { hours monthly of premier and } \\
\text { replay programmes ( } 10 \text { minutes of daily information programmes }+ \\
\text { weekly: } 1.5 \text { hours of information-political and cultural programmes } \\
\text { and } 1 \text { hour of magazine }+1.5 \text { hours monthly of family magazine). }\end{array}$ \\
\hline Slovak language & $\begin{array}{l}\text { In average } 1 \text { hour daily, namely } 58 \text { hours monthly of premier and } \\
\text { replay programmes ( } 10 \text { minutes of daily information programmes }+ \\
\text { weekly: } 1.5 \text { hours of information-political and cultural programmes } \\
\text { and } 1 \text { hour of magazine }+1.5 \text { hours monthly of family magazine). }\end{array}$ \\
\hline
\end{tabular}




\begin{tabular}{|c|l|}
\hline Ukrainian language & \multicolumn{1}{c|}{0.5 hour weekly } \\
\hline Croatian language & $\begin{array}{l}\text { 6 hours monthly in total (10 minutes daily }+0.5 \text { hours on Saturdays } \\
\text { and Sundays). }\end{array}$ \\
\hline Bunjevac speech & 0.5 hour weekly \\
\hline Macedonian language & 0.5 hour weekly \\
\hline
\end{tabular}

294. The Provincial Secretariat of Information of AP of Vojvodina granted to RTV Vojvodina the funds in the amount of 14,274,741 dinars for information services and capital investments for equipment, which were internally distributed to sectors, media and editorial offices.

\subsubsection{Encouragement and facilitation of radio programmes in minority languages}

295. The Ministry of Culture - the Media Sector issues an annual tender for cofinancing of projects/programmes in the field of public information and the Provincial Secretariat of Information of AP of Vojvodina issues a tender for equipment, promotion of programme and information to public in minority languages. The public companies founded by the units of local self-government are partially financed from their budgets. The Tables below contain the data on co-financing of regular radio programme broadcasting in minority languages on tender basis, through allocation of funds from the republic and provincial budgets to those radio stations broadcasting programmes in minority languages.

\section{Albanian language}

\begin{tabular}{|c|c|c|}
\hline Broadcaster & $\begin{array}{l}\text { Duration of Radio } \\
\text { Programme }\end{array}$ & $\begin{array}{c}\text { Measures of Encouragement and Facilitation } \\
\text { of Programme Broadcasting }\end{array}$ \\
\hline $\begin{array}{l}\text { Multi-lingual Program } \\
\text { Broadcasting - Public } \\
\text { Companies }\end{array}$ & & \\
\hline $\begin{array}{c}\text { RTV Bujanovac } \\
\text { Radio Bujanovac, } \\
\text { Bujanovac }\end{array}$ & $\begin{array}{c}6.5 \text { hours daily } \\
\text { (ceased to operate in } 2009 \text {, } \\
\text { waiting for a licence from the } \\
\text { RBA) }\end{array}$ & $\begin{array}{l}\text { In } 2007 \text { the Ministry of Culture granted 321,980 } \\
\text { dinars for technical equipment for the radio. }\end{array}$ \\
\hline
\end{tabular}


Bosniak language

\begin{tabular}{|c|c|c|}
\hline Broadcaster & $\begin{array}{l}\text { Duration of Radio } \\
\text { Programme }\end{array}$ & $\begin{array}{l}\text { Measures of Encouragement and Facilitation } \\
\text { of Programme Broadcasting }\end{array}$ \\
\hline $\begin{array}{l}\text { Broadcasting in Bosni } \\
\text { Language only - Othe } \\
\text { Broadcasters }\end{array}$ & & \\
\hline $\begin{array}{l}\text { Bošnjački radio, } \\
\text { Tutin }\end{array}$ & $\begin{array}{l}24 \text { hours daily planned, } \\
\text { (should start operation upon } \\
\text { the installation of equipment) }\end{array}$ & $\begin{array}{l}\text { In } 2009 \text { the Ministry of Culture granted 540,000 } \\
\text { dinars for the radio news programme. }\end{array}$ \\
\hline
\end{tabular}

Bulgarian language

\begin{tabular}{|c|c|c|}
\hline Broadcaster & $\begin{array}{c}\text { Duration of Radio } \\
\text { Programme }\end{array}$ & $\begin{array}{c}\text { Measures of Encouragement and Facilitation } \\
\text { of Programme Broadcasting }\end{array}$ \\
\hline $\begin{array}{l}\text { Multi-lingual Programme } \\
\text { Broadcasting - Public } \\
\text { Companies }\end{array}$ & & \\
\hline $\begin{array}{c}\text { Radio Bosilegrad, } \\
\text { Bosilegrad }\end{array}$ & $70 \%$ of 24 hours daily & $\begin{array}{l}\text { In } 2007 \text { the Ministry of Culture granted } 344,000 \\
\text { dinars for technical equipment. }\end{array}$ \\
\hline
\end{tabular}

\section{Hungarian language}

\begin{tabular}{|c|c|c|}
\hline Broadcaster & $\begin{array}{l}\text { Duration of Radio } \\
\text { Programme }\end{array}$ & $\begin{array}{c}\text { Measures of Encouragement and Facilitation } \\
\text { of Programme Broadcasting }\end{array}$ \\
\hline \multicolumn{3}{|l|}{$\begin{array}{l}\text { Broadcasting in Hungarian } \\
\text { Language only - Public } \\
\text { Companies }\end{array}$} \\
\hline $\begin{array}{c}\text { Radio Subotica, } \\
\text { Editorial Office in Hungarian } \\
\text { Language, } \\
\text { Subotica }\end{array}$ & 18 hours daily & $\begin{array}{l}\text { In } 2008 \text { the Ministry of Culture granted 392,000 } \\
\text { dinars for the Srpski manastiri na Fruškoj Gori } \\
\text { and for the documentary radio programme on } \\
\text { culture of the Hungarians in Vojvodina, in } 2009 \text {, } \\
340,000 \text { dinars for the Žene i društveni problemi } \\
\text { series and the Svakodnevna ekologija } \\
\text { programme; } \\
\text { The Provincial Secretariat of Information granted } \\
3,412,000 \text { dinars in total for equipment, } \\
\text { promotion of programme, information services } \\
\text { and information to public at the company level. }\end{array}$ \\
\hline \multicolumn{3}{|l|}{$\begin{array}{l}\text { Broadcasting in Hungarian } \\
\text { Language only - Other } \\
\text { Broadcasters }\end{array}$} \\
\hline $\begin{array}{l}\text { RTV Pannon } \\
\text { Radio Pannon, } \\
\text { Subotica }\end{array}$ & 24 hours daily & $\begin{array}{l}\text { The Provincial Secretariat of Information granted } \\
8,193,000 \text { dinars in total for equipment, } \\
\text { promotion of programme, information services } \\
\text { and information to public. } \\
\text { (the funds were awarded to the radio and TV } \\
\text { programmes at the level of RTV). }\end{array}$ \\
\hline
\end{tabular}




\begin{tabular}{|c|c|c|}
\hline $\begin{array}{l}\text { Multi-lingual Programme } \\
\text { Broadcasting - Public } \\
\text { Companies }\end{array}$ & & \\
\hline $\begin{array}{l}\text { Radio regije, } \\
\text { Bačka Topola }\end{array}$ & 1 hour weekly & $\begin{array}{l}\text { In } 2007 \text { the Ministry of Culture granted } 417,000 \\
\text { dinars for broadcasting of programmes in } \\
\text { minority languages an in } 2009 \text { it granted } 210,000 \\
\text { dinars for programmes in Hungarian language; } \\
\text { The Provincial Secretariat of Information granted } \\
500,000 \text { dinars in total for information to public. }\end{array}$ \\
\hline $\begin{array}{c}\text { Radio Bela Crkva, } \\
\text { Bela Crkva }\end{array}$ & 1 hour weekly & $\begin{array}{l}\text { The Provincial Secretariat of Information granted } \\
650,000 \text { dinars in total for information to public. }\end{array}$ \\
\hline $\begin{array}{l}\text { RTV Vrbas } \\
\text { Radio Vrbas, } \\
\text { Vrbas }\end{array}$ & $\begin{array}{l}45 \text { minutes daily, five days a } \\
\text { week }+1 \text { hour weekly }\end{array}$ & $\begin{array}{l}\text { The Provincial Secretariat of Information granted } \\
2,882,520 \text { dinars in total for equipment, } \\
\text { information services and information to public. }\end{array}$ \\
\hline $\begin{array}{l}\text { Radio Zrenjanin, } \\
\text { Zrenjanin }\end{array}$ & 1 hour daily & $\begin{array}{l}\text { In } 2007 \text { the Ministry of Culture granted } 432,000 \\
\text { dinars for programmes in minority languages. In } \\
2008 \text { it granted } 340,000 \text { dinars for the } \\
\text { programme for the young in the minority } \\
\text { languages; } \\
\text { The Provincial Secretariat of Information granted } \\
3,298,000 \text { dinars in total for equipment, } \\
\text { information services and information to public. }\end{array}$ \\
\hline $\begin{array}{l}\text { Radio Kikinda, } \\
\text { Kikinda }\end{array}$ & $\begin{array}{c}\text { Daily news }+10 \text { hours } \\
\text { weekly }\end{array}$ & $\begin{array}{l}\text { The Provincial Secretariat of Information granted } \\
400,000 \text { dinars in total for information services } \\
\text { and information to public. }\end{array}$ \\
\hline $\begin{array}{l}\text { RTV Kovačica } \\
\text { Radio Kovačica, } \\
\text { Kovačica }\end{array}$ & 2.5 hours daily & $\begin{array}{l}\text { The Provincial Secretariat of Information granted } \\
3,996,000 \text { dinars in total for equipment, } \\
\text { promotion of programme, information services } \\
\text { and information to public. }\end{array}$ \\
\hline $\begin{array}{l}\text { Radio Novi Bečej, } \\
\quad \text { Novi Bečej }\end{array}$ & $\begin{array}{l}2 \text { hours daily, six days a } \\
\text { week }\end{array}$ & $\begin{array}{l}\text { The Provincial Secretariat of Information granted } \\
550,000 \text { dinars in total for information services } \\
\text { and information to public. }\end{array}$ \\
\hline $\begin{array}{l}\text { Radio Odžaci, } \\
\text { Odžaci }\end{array}$ & 2 hours weekly & $\begin{array}{l}\text { The Provincial Secretariat of Information granted } \\
1,100,000 \text { dinars in total for equipment, } \\
\text { information services and information to public. }\end{array}$ \\
\hline $\begin{array}{l}\text { Radio Sečanj, } \\
\quad \text { Sečanj }\end{array}$ & 1 hour weekly & $\begin{array}{l}\text { In } 2007 \text { the Ministry of Culture granted } 160,500 \\
\text { dinars for programmes in Romanian and } \\
\text { Hungarian languages and in } 2008 \text { it granted } \\
324.000 \text { dinars for the Multijezična Vojvodina } u \\
\text { malom; } \\
\text { The Provincial Secretariat of Information granted } \\
1,166,000 \text { dinars in total for equipment, } \\
\text { information services and information to public. }\end{array}$ \\
\hline \multicolumn{3}{|l|}{$\begin{array}{l}\text { Multi-lingual Programme } \\
\text { Broadcasting - Other } \\
\text { Broadcasters }\end{array}$} \\
\hline $\begin{array}{l}\text { Radio Ada, } \\
\text { Ada }\end{array}$ & 15 hours daily & $\begin{array}{l}\text { The Provincial Secretariat of Information granted } \\
150,000 \text { dinars in total for information to public. }\end{array}$ \\
\hline
\end{tabular}




\begin{tabular}{|c|c|c|}
\hline $\begin{array}{l}\text { Radio Trend, } \\
\text { Bačka Topola }\end{array}$ & $\begin{array}{l}30 \text { to } 40 \% \text { of } 24 \text { hours daily } \\
\text { programme }\end{array}$ & $\begin{array}{l}\text { In } 2009 \text { the Ministry of Culture granted } 450,000 \\
\text { dinars for programme on tolerance in } 4 \\
\text { languages; } \\
\text { The Provincial Secretariat of Information granted } \\
1,247,562 \text { dinars in total for equipment and } \\
\text { information to public. }\end{array}$ \\
\hline $\begin{array}{l}\text { Radio Active, } \\
\text { Bečej }\end{array}$ & 10 hours & $\begin{array}{l}\text { The Provincial Secretariat of Information granted } \\
1,010,000 \text { dinars in total for equipment, } \\
\text { promotion of programme, information services } \\
\text { and information to public. }\end{array}$ \\
\hline $\begin{array}{c}\text { Panda Radio, } \\
\text { Kanjiža }\end{array}$ & 17 hours daily & $\begin{array}{l}\text { The Provincial Secretariat of Information granted } \\
270,000 \text { dinars in total for information to public. }\end{array}$ \\
\hline $\begin{array}{l}\text { Radio Bus, } \\
\quad \text { Kovin }\end{array}$ & 1.5 hours weekly & $\begin{array}{l}\text { The Provincial Secretariat of Information granted } \\
1,354,000 \text { dinars in total for equipment, } \\
\text { information services and information to public. }\end{array}$ \\
\hline $\begin{array}{l}\text { Radio Zenit, } \\
\text { Kula }\end{array}$ & 1.5 hours daily & $\begin{array}{l}\text { In } 2007 \text { the Provincial Secretariat of Information } \\
\text { granted } 300,000 \text { dinars for equipment. }\end{array}$ \\
\hline $\begin{array}{l}\text { Radio Blue, } \\
\text { Odžaci }\end{array}$ & 0.5 hour weekly & $\begin{array}{l}\text { In } 2008 \text { the Ministry of Culture granted } 350,000 \\
\text { dinars for the Bogatstvo naše kulture radio } \\
\text { programme; } \\
\text { The Provincial Secretariat of Information granted } \\
1,252,000 \text { dinars in total for equipment, } \\
\text { information services and information to public. }\end{array}$ \\
\hline $\begin{array}{l}\text { Radio Blue Plus, } \\
\text { Odžaci }\end{array}$ & 0.5 hours weekly & $\begin{array}{l}\text { The Provincial Secretariat of Information granted } \\
902,000 \text { dinars in total for equipment, } \\
\text { information services and information to public }\end{array}$ \\
\hline $\begin{array}{l}\text { Radio Sombor, } \\
\text { Sombor }\end{array}$ & 2 hours daily & $\begin{array}{l}\text { The Provincial Secretariat of Information granted } \\
3,072,000 \text { dinars in total for equipment, } \\
\text { information services and information to public. }\end{array}$ \\
\hline $\begin{array}{l}\text { Radio Srbobran, } \\
\text { Srbobran }\end{array}$ & $\begin{array}{l}4 \text { hours daily, } 6 \text { hours on } \\
\text { Saturday }\end{array}$ & $\begin{array}{l}\text { The Provincial Secretariat of Information granted } \\
780,007 \text { dinars in total for equipment, promotion } \\
\text { of programme, information services and } \\
\text { information to public. }\end{array}$ \\
\hline $\begin{array}{l}\text { Radio Temerin, } \\
\text { Temerin }\end{array}$ & 5 hours daily & $\begin{array}{l}\text { In } 2009 \text { the Ministry of Culture granted } 320,000 \\
\text { dinars for the series of programmes in Hungarian } \\
\text { language; } \\
\text { The Provincial Secretariat of Information granted } \\
296,000 \text { dinars in total for equipment and } \\
\text { information to public. }\end{array}$ \\
\hline
\end{tabular}

\section{Romani language}

\begin{tabular}{|c|c|c|}
\hline Broadcaster & $\begin{array}{l}\text { Duration of Radio } \\
\text { Programme }\end{array}$ & $\begin{array}{c}\text { Measures of Encouragement and Facilitation } \\
\text { of Programme Broadcasting }\end{array}$ \\
\hline $\begin{array}{l}\text { Multi-lingual Programm } \\
\text { Broadcasting - Public } \\
\text { Companies }\end{array}$ & & \\
\hline $\begin{array}{l}\text { Radio Bela Crkva, } \\
\text { Bela Crkva }\end{array}$ & 1 hour weekly & $\begin{array}{l}\text { The Provincial Secretariat of Information granted } \\
650,000 \text { dinars in total for information to public. }\end{array}$ \\
\hline
\end{tabular}




\begin{tabular}{|c|c|c|}
\hline $\begin{array}{l}\text { RTV Bujanovac } \\
\text { Radio Bujanovac, } \\
\text { Bujanovac }\end{array}$ & $\begin{array}{c}1 \text { hour weekly } \\
\text { (ceased to operate in } 2009 \text {, } \\
\text { waits for licence from RBA) }\end{array}$ & $\begin{array}{l}\text { In } 2007 \text { the Ministry of Culture granted 321,980 } \\
\text { dinars for technical equipment for the radio. }\end{array}$ \\
\hline $\begin{array}{l}\text { Radio Kikinda, } \\
\text { Kikinda }\end{array}$ & 4 hours weekly & $\begin{array}{l}\text { In } 2008 \text { the Ministry of Culture granted } 200,000 \\
\text { dinars for the Romski san; } \\
\text { The Provincial Secretariat of Information granted } \\
400,000 \text { dinars in total information services and } \\
\text { information to public. }\end{array}$ \\
\hline $\begin{array}{l}\text { Radio Novi Bečej, } \\
\text { Novi Bečej }\end{array}$ & 1 hour weekly & $\begin{array}{l}\text { The Provincial Secretariat of Information granted } \\
550,000 \text { dinars in total for information services } \\
\text { and information to public. }\end{array}$ \\
\hline $\begin{array}{c}\text { Radio Odžaci, } \\
\text { Odžaci }\end{array}$ & 2 hours weekly & $\begin{array}{l}\text { The Provincial Secretariat of Information granted } \\
1,100,000 \text { dinars in total for equipment, } \\
\text { information services and information to public. }\end{array}$ \\
\hline $\begin{array}{c}R T V \text { Trstenik } \\
\text { Radio Trstenik, } \\
\text { Trstenik } \\
\end{array}$ & 1 hour weekly & $\begin{array}{l}\text { In } 2007 \text { the Ministry of Culture granted } 250,000 \\
\text { dinars in total for broadcasting in Romani } \\
\text { language and in } 2008 \text { it granted } 310,000 \text { dinars. }\end{array}$ \\
\hline $\begin{array}{l}\text { Multi-lingual Programm } \\
\text { Broadcasting - Other } \\
\text { Broadcasters }\end{array}$ & & \\
\hline $\begin{array}{l}\text { RTV Khrlo e Romengo } \\
\text { Radio Khrlo e Romengo, } \\
\quad \text { Belgrade }\end{array}$ & $\begin{array}{c}10 \text { hours daily } \\
\text { (ceased to operate in 2008) }\end{array}$ & $\begin{array}{l}\text { In } 2007 \text { the Ministry of Culture granted 450,000 } \\
\text { dinars for technical equipment. }\end{array}$ \\
\hline $\begin{array}{l}\text { Radio Ema, } \\
\text { Bujanovac }\end{array}$ & $\begin{array}{l}\text { 15-minutes daily information } \\
\text { programme }+8 \text { hours of } \\
\text { programme monthly }\end{array}$ & $\begin{array}{l}\text { In } 2008 \text { the Ministry of Culture granted 500,000 } \\
\text { dinars for Romi i civilno društvo and in } 2009 \text { it } \\
\text { granted } 320,000 \text { dinars for information } \\
\text { programme in Romani language. }\end{array}$ \\
\hline $\begin{array}{l}\text { Radio Bus, } \\
\quad \text { Kovin }\end{array}$ & 1 hour monthly & $\begin{array}{l}\text { The Provincial Secretariat of Information granted } \\
1,354,000 \text { dinars in total for equipment, } \\
\text { information services and information to public. }\end{array}$ \\
\hline $\begin{array}{l}\text { Radio Rom, } \\
\text { Obrenovac }\end{array}$ & $\begin{array}{l}24 \text { hours, } \\
\text { Major part in Romani }\end{array}$ & $\begin{array}{l}\text { In } 2007 \text { the Ministry of Culture granted } 450,000 \\
\text { dinars, in } 2008 \text { it granted } 690,000 \text { dinars and in } \\
2009 \text { it granted } 408,904 \text { dinars for the Reč Roma } \\
\text { programme. }\end{array}$ \\
\hline $\begin{array}{l}\text { Radio Blue, } \\
\text { Odžaci }\end{array}$ & 0.5 hour weekly & $\begin{array}{l}\text { In } 2008 \text { the Ministry of Culture granted } 350,000 \\
\text { dinars for the Bogatstvo naše culture radio } \\
\text { programme; } \\
\text { The Provincial Secretariat of Information granted } \\
1,252,000 \text { dinars in total for equipment, } \\
\text { information services and information to public. }\end{array}$ \\
\hline $\begin{array}{l}\text { Radio Sombor } \\
\text { Sombor }\end{array}$ & 1.5 hours daily & $\begin{array}{l}\text { The Provincial Secretariat of Information granted } \\
3,072,000 \text { dinars in total for equipment, } \\
\text { information services and information to public. }\end{array}$ \\
\hline $\begin{array}{l}\text { Radio Srbobran } \\
\text { Srbobran }\end{array}$ & 1 hour weekly & $\begin{array}{l}\text { In } 2008 \text { the Ministry of Culture granted } 300,000 \\
\text { dinars for broadcasting of programmes in } \\
\text { Romani; } \\
\text { The Provincial Secretariat of Information granted } \\
780,007 \text { dinars total for equipment, promotion of } \\
\text { programme, information services and } \\
\text { information to public. }\end{array}$ \\
\hline
\end{tabular}


Romanian language

\begin{tabular}{|c|c|c|}
\hline Broadcaster & $\begin{array}{c}\text { Duration of Radio } \\
\text { Programme }\end{array}$ & $\begin{array}{c}\text { Measures of Encouragement and Facilitation } \\
\text { of Programme Broadcasting }\end{array}$ \\
\hline \multicolumn{3}{|l|}{$\begin{array}{l}\text { Broadcasting in Romanian } \\
\text { Language only - Other } \\
\text { Broadcasters }\end{array}$} \\
\hline $\begin{array}{l}\text { RTV Viktorija } \\
\text { Radio Viktorija, } \\
\text { Vršac }\end{array}$ & 24 hours daily & $\begin{array}{l}\text { In } 2007 \text { the Ministry of Culture granted } 60,000 \\
\text { dinars and in } 2008 \text { it granted } 300,000 \text { dinars; } \\
\text { The Provincial Secretariat of Information granted } \\
1,663,000 \text { dinars in total for information services } \\
\text { and information to public. }\end{array}$ \\
\hline \multicolumn{3}{|l|}{$\begin{array}{l}\text { Multi-lingual Programme } \\
\text { Broadcasting - Public } \\
\text { Companies }\end{array}$} \\
\hline $\begin{array}{c}\text { Radio Bela Crkva, } \\
\text { Bela Crkva }\end{array}$ & 1 hour weekly & $\begin{array}{l}\text { The Provincial Secretariat of Information granted } \\
650,000 \text { dinars in total for information to public. }\end{array}$ \\
\hline $\begin{array}{l}\text { Radio Zrenjanin, } \\
\text { Zrenjanin }\end{array}$ & 1.5 hour weekly & $\begin{array}{l}\text { In } 2007 \text { the Ministry of Culture granted } 432,000 \\
\text { dinars for broadcasting in minority languages. In } \\
2008 \text { it granted } 340,000 \text { dinars for programme } \\
\text { for the young in minority languages; } \\
\text { The Provincial Secretariat of Information granted } \\
3,298,000 \text { dinars in total for equipment, } \\
\text { information services and information to public. }\end{array}$ \\
\hline $\begin{array}{l}\text { Radio Kikinda, } \\
\text { Kikinda }\end{array}$ & 2 hours weekly & $\begin{array}{l}\text { The Provincial Secretariat of Information granted } \\
400,000 \text { dinars in total for information services } \\
\text { and information to public. }\end{array}$ \\
\hline $\begin{array}{l}\text { RTV Kovačica } \\
\text { Radio Kovačica, } \\
\text { Kovačica }\end{array}$ & 2.5 hours daily & $\begin{array}{l}\text { The Provincial Secretariat of Information granted } \\
3,996,000 \text { dinars in total for equipment, } \\
\text { promotion of programme, information services } \\
\text { and information to public. }\end{array}$ \\
\hline $\begin{array}{l}\text { Radio Kovin, } \\
\text { Kovin }\end{array}$ & 2 hours daily & $\begin{array}{l}\text { In } 2007 \text { the Provincial Secretariat of Information } \\
\text { granted 346,000 dinars for equipment, } \\
\text { information services and information to public. }\end{array}$ \\
\hline $\begin{array}{l}\text { Radio Sečanj, } \\
\quad \text { Sečanj }\end{array}$ & 1 hour weekly & $\begin{array}{l}\text { In } 2007 \text { the Ministry of Culture granted } 160,500 \\
\text { dinars for broadcasting in Hungarian and } \\
\text { Romanian and in } 2008 \text { it granted } 324,000 \text { dinars } \\
\text { for the Multijezična Vojvodina u malom } \\
\text { programme; } \\
\text { The Provincial Secretariat of Information granted } \\
\text { 1,166,000 dinars in total for equipment, } \\
\text { information services and information to public. }\end{array}$ \\
\hline \multicolumn{3}{|l|}{$\begin{array}{l}\text { Multi-lingual Programme } \\
\text { Broadcasting - Other } \\
\text { Broadcasters }\end{array}$} \\
\hline $\begin{array}{l}\text { Radio Far, } \\
\text { Alibunar }\end{array}$ & 4 hours daily & $\begin{array}{l}\text { In } 2007 \text { the Ministry of Culture granted } 40,000 \\
\text { dinars for broadcasting in Romanian and in } 2008 \\
\text { it granted 140,000 dinars for the Mladi za mlade } \\
\text { programme; }\end{array}$ \\
\hline
\end{tabular}




\begin{tabular}{|c|l|l|}
\hline & & $\begin{array}{l}\text { The Provincial Secretariat of Information granted } \\
800,000 \text { dinars in total for equipment and } \\
\text { information to public. }\end{array}$ \\
\hline $\begin{array}{c}\text { Radio Bela Crkva, } \\
\text { Bela Crkva }\end{array}$ & $\begin{array}{l}\text { The Provincial Secretariat of Information granted } \\
650,000 \text { dinars in total for information to public. }\end{array}$ \\
\hline $\begin{array}{c}\text { Radio Bus, } \\
\text { Kovin }\end{array}$ & 1 hour weekly & $\begin{array}{l}\text { The Provincial Secretariat of Information granted } \\
1,354,000 \text { dinars in total for equipment, } \\
\text { information services and information to public. }\end{array}$ \\
\hline
\end{tabular}

\section{Ruthenian language}

\begin{tabular}{|c|c|c|}
\hline Broadcaster & $\begin{array}{c}\text { Duration of Radio } \\
\text { Programme }\end{array}$ & $\begin{array}{c}\text { Measures of Encouragement and Facilitation } \\
\text { of Programme Broadcasting }\end{array}$ \\
\hline \multicolumn{3}{|c|}{$\begin{array}{l}\text { Multi-lingual Programme } \\
\text { Broadcasting - Public } \\
\text { Companies }\end{array}$} \\
\hline $\begin{array}{l}\text { Radio Regije, } \\
\text { Bačka Topola }\end{array}$ & 0.5 hour weekly & $\begin{array}{l}\text { In } 2007 \text { the Ministry of Culture granted } \\
417,000.00 \text { dinars for broadcasting in minority } \\
\text { languages and in } 2008 \text { it granted } 80,000.00 \\
\text { dinars for information in Ruthenian language; } \\
\text { The Provincial Secretariat of Information granted } \\
500,000.00 \text { dinars in total for information to } \\
\text { public. }\end{array}$ \\
\hline $\begin{array}{l}\text { RTV Vrbas } \\
\text { Radio Vrbas, } \\
\text { Vrbas }\end{array}$ & $\begin{array}{l}45 \text { minutes daily five days a } \\
\text { week }+1 \text { hour weekly }\end{array}$ & $\begin{array}{l}\text { The Provincial Secretariat of Information granted } \\
2,882,520 \text { dinars in total for equipment, } \\
\text { information services and information to public. }\end{array}$ \\
\hline $\begin{array}{l}\text { Radio } \check{\text { Šid }}, \\
\text { Šid }\end{array}$ & 0.5 hours weekly & $\begin{array}{l}\text { The Provincial Secretariat of Information granted } \\
648,000 \text { dinars in total for equipment, } \\
\text { information services and information to public. }\end{array}$ \\
\hline \multicolumn{3}{|c|}{$\begin{array}{l}\text { Multi-lingual Programme } \\
\text { Broadcasting - Other } \\
\text { Broadcasters }\end{array}$} \\
\hline $\begin{array}{l}\text { Radio Trend, } \\
\text { Bačka Topola }\end{array}$ & 1 hour weekly & $\begin{array}{l}\text { In } 2009 \text { the Ministry of Culture granted } 450,000 \\
\text { dinars for programmes for tolerance in } 4 \\
\text { languages; } \\
\text { The Provincial Secretariat of Information granted } \\
1,247,562 \text { dinars in total for equipment, } \\
\text { information services and information to public. }\end{array}$ \\
\hline $\begin{array}{l}\text { Radio Zenit, } \\
\text { Kula }\end{array}$ & 1.5 hour daily & $\begin{array}{l}\text { In } 2007 \text { the Provincial Secretariat of Information } \\
\text { granted } 300,000 \text { dinars in total for equipment. }\end{array}$ \\
\hline $\begin{array}{l}\text { Radio Blue, } \\
\text { Odžaci }\end{array}$ & 0.5 hour weekly & $\begin{array}{l}\text { In } 2008 \text { the Ministry of Culture granted } 350,000 \\
\text { dinars for the Bogatstvo naše culture radio } \\
\text { programme; } \\
\text { The Provincial Secretariat of Information granted } \\
1,252,000 \text { dinars in total for equipment, } \\
\text { information services and information to public. }\end{array}$ \\
\hline Radio Blue Plus, & 0.5 hour weekly & $\begin{array}{l}\text { The Provincial Secretariat of Information granted } \\
902,000 \text { dinars in total for equipment, }\end{array}$ \\
\hline
\end{tabular}




\section{Slovak language}

\begin{tabular}{|c|c|c|}
\hline Broadcaster & $\begin{array}{l}\text { Duration of Radio } \\
\text { Programme }\end{array}$ & $\begin{array}{c}\text { Measures of Encouragement and Facilitation } \\
\text { of Programme Broadcasting }\end{array}$ \\
\hline \multicolumn{3}{|l|}{$\begin{array}{l}\text { Multi-lingual Programme } \\
\text { Broadcasting - Public } \\
\text { Companies }\end{array}$} \\
\hline $\begin{array}{c}\text { Radio Вас̌кa, } \\
\text { Вас̌ }\end{array}$ & 5 hours weekly & $\begin{array}{l}\text { The Provincial Secretariat of Information granted } \\
1,850,000 \text { dinars in total for equipment, } \\
\text { promotion of programme, information services } \\
\text { and information to public. }\end{array}$ \\
\hline $\begin{array}{l}\text { Radio Zrenjanin, } \\
\text { Zrenjanin }\end{array}$ & 1.5 hour weekly & $\begin{array}{l}\text { In } 2007 \text { the Ministry of Culture granted } 432,000 \\
\text { dinars for programmes in minority languages and } \\
\text { in } 2008 \text { it granted } 340,000 \text { dinars for programme } \\
\text { for the young in minority languages. } \\
\text { The Provincial Secretariat of Information granted } \\
3,298,000 \text { dinars for equipment, information } \\
\text { services and information to public. }\end{array}$ \\
\hline $\begin{array}{l}\text { RTV Kovačica } \\
\text { Radio Kovačica, } \\
\text { Kovačica }\end{array}$ & 6 hours daily & $\begin{array}{l}\text { The Provincial Secretariat of Information granted } \\
3,996,200 \text { dinars in total for equipment, } \\
\text { promotion of programme, information services } \\
\text { and information to public. }\end{array}$ \\
\hline $\begin{array}{l}\text { Radio Odžaci, } \\
\text { Odžaci }\end{array}$ & 2 hours weekly & $\begin{array}{l}\text { The Provincial Secretariat of Information granted } \\
1,100,000 \text { dinars in total for equipment, } \\
\text { information services and information to public. }\end{array}$ \\
\hline $\begin{array}{c}\text { Radio Stara Pazova } \\
\text { Stara Pazova }\end{array}$ & 5 hours daily & $\begin{array}{l}\text { In } 2007 \text { the Ministry of Culture granted } 35,000 \\
\text { dinars. } \\
\text { The Provincial Secretariat of Information granted } \\
1,350,000 \text { dinars in total for information services } \\
\text { and information to public. }\end{array}$ \\
\hline $\begin{array}{l}\text { Radio Šid, } \\
\text { Šid }\end{array}$ & 1 hour weekly & $\begin{array}{l}\text { The Provincial Secretariat of Information granted } \\
648,000 \text { dinars in total for equipment, } \\
\text { information services and information to public. }\end{array}$ \\
\hline \multicolumn{3}{|l|}{$\begin{array}{l}\text { Multi-lingual Programme } \\
\text { Broadcasting - Other } \\
\text { Broadcasters }\end{array}$} \\
\hline $\begin{array}{l}\text { Radio Far, } \\
\text { Alibunar }\end{array}$ & 1 hour daily & $\begin{array}{l}\text { In } 2008 \text { the Ministry of Culture granted } 140,000 \\
\text { dinars for Mladi za mlade programme. } \\
\text { The Provincial Secretariat of Information granted } \\
800,000 \text { dinars for equipment and information to } \\
\text { public. }\end{array}$ \\
\hline $\begin{array}{l}\text { Radio Trend, } \\
\text { Bačka Topola }\end{array}$ & 1 hour weekly & $\begin{array}{l}\text { In } 2009 \text { the Ministry of Culture granted } 450,000 \\
\text { dinars for the programme on tolerance in } 4 \\
\text { languages. } \\
\text { The Provincial Secretariat of Information granted } \\
1,247,562 \text { dinars for equipment, information } \\
\text { services and information to public. }\end{array}$ \\
\hline & & In 2007 the Ministry of Culture granted 100,000 \\
\hline
\end{tabular}




\begin{tabular}{|c|c|c|}
\hline $\begin{array}{c}\text { Radio Bački Petrovac, } \\
\text { Bački Petrovac }\end{array}$ & $\begin{array}{c}24 \text { hours daily } \\
\text { (major part in Slovak) }\end{array}$ & $\begin{array}{l}\text { dinars. } \\
\text { The Provincial Secretariat of Information granted } \\
1,483,512 \text { dinars for equipment, promotion of } \\
\text { programme, information services and } \\
\text { information to public. }\end{array}$ \\
\hline $\begin{array}{l}\text { Radio Kisač } \\
\text { Novi Sad }\end{array}$ & $\begin{array}{c}14 \text { hours weekly }+12 \text { hours } \\
\text { on Fridays }+ \\
6 \text { hours daily on other days }\end{array}$ & $\begin{array}{l}\text { The Provincial Secretariat of Information granted } \\
813,000 \text { dinars in total for information services } \\
\text { and information to public. }\end{array}$ \\
\hline $\begin{array}{c}\text { Radio Blue, } \\
\text { Odžaci }\end{array}$ & 0.5 hour weekly & $\begin{array}{l}\text { In } 2008 \text { the Ministry of Culture granted } 350,000 \\
\text { dinars the Bogatstvo naše culture radio } \\
\text { programme and in } 2009 \text { it granted } 84,000 \text { dinars } \\
\text { for the Žena stub slovačke evangelističke crkve } \\
\text { programme. } \\
\text { The Provincial Secretariat of Information granted } \\
1,252,000 \text { dinars in total for equipment, } \\
\text { information services and information to public. }\end{array}$ \\
\hline $\begin{array}{c}\text { Radio Blue Plus, } \\
\text { Odžaci }\end{array}$ & 0.5 hours weekly & $\begin{array}{l}\text { In } 2008 \text { the Ministry of Culture granted } 100,000 \\
\text { dinars for the Blu nedeljnik in Slovak and in } \\
2009 \text { it granted } 270.000 \text { dinars for the } \\
\text { Upoznajmo Vojvodinu programme; } \\
\text { The Provincial Secretariat of Information granted } \\
902,000 \text { dinars in total for equipment, } \\
\text { information services and information to public. }\end{array}$ \\
\hline
\end{tabular}

\section{Ukrainian language}

\begin{tabular}{|c|c|l|}
\hline Broadcaster & $\begin{array}{c}\text { Duration of Radio } \\
\text { Programme }\end{array}$ & $\begin{array}{c}\text { Measures of Encouragement and Facilitation } \\
\text { of Programme Broadcasting }\end{array}$ \\
\hline $\begin{array}{c}\text { Multi-lingual Programme } \\
\text { Broadcasting - Public } \\
\text { Companies }\end{array}$ & 1 hour weekly & $\begin{array}{l}\text { The Provincial Secretariat of Information granted } \\
2,882,520 \text { dinars in total for equipment, } \\
\text { information services and information to public. }\end{array}$ \\
\hline $\begin{array}{c}\text { RTV Vrbas } \\
\text { Vrbas }\end{array}$ & 1 hour weekly & $\begin{array}{l}\text { In 2007 the Ministry of Culture granted 200,000 } \\
\text { dinars for programme in Ukrainian and in 2009 it } \\
\text { granted 264,000 dinars for documentary- } \\
\text { information programme in Ukrainian. }\end{array}$ \\
\hline $\begin{array}{c}\text { RTV Indija } \\
\text { Indija }\end{array}$ & & $\begin{array}{l}\text { In } 2007 \text { the Provincial Secretariat of Information } \\
\text { granted 300,000 dinars in total for equipment. }\end{array}$ \\
\hline $\begin{array}{c}\text { Multi-lingual Programme } \\
\text { Broadcasting - Other } \\
\text { Broadcasters }\end{array}$ & 1 hour weekly & \\
\hline $\begin{array}{c}\text { Radio Zenit, } \\
\text { Kula }\end{array}$ & & \\
\hline
\end{tabular}

\section{Croatian language}




\begin{tabular}{|c|c|c|}
\hline Broadcaster & $\begin{array}{l}\text { Duration of Radio } \\
\text { Programme }\end{array}$ & $\begin{array}{c}\text { Measures of Encouragement and Facilitation } \\
\text { of Programme Broadcasting }\end{array}$ \\
\hline \multicolumn{3}{|c|}{$\begin{array}{l}\text { Multi-lingual Programme } \\
\text { Broadcasting - Public } \\
\text { Companies }\end{array}$} \\
\hline $\begin{array}{c}\text { Radio Subotica } \\
\text { Subotica }\end{array}$ & $\begin{array}{l}3 \text { hours of programme from } \\
\text { Monday to Friday }+ \text { religious } \\
\text { programme on Saturdays }\end{array}$ & $\begin{array}{l}\text { The Provincial Secretariat of Information granted } \\
3,412,000 \text { dinars in total for equipment, } \\
\text { promotion of programme, information services } \\
\text { and information to public. }\end{array}$ \\
\hline Radio Вас̌ка, Вас̌ & 0.5 hour weekly & $\begin{array}{l}\text { The Provincial Secretariat of Information granted } \\
1,850,000 \text { dinars in total for equipment, } \\
\text { promotion of programme, information services } \\
\text { and information to public. }\end{array}$ \\
\hline $\begin{array}{l}\text { Radio Odžaci, } \\
\text { Odžaci }\end{array}$ & 0.5 hour weekly & $\begin{array}{l}\text { The Provincial Secretariat of Information granted } \\
1,100,000 \text { dinars in total for equipment, } \\
\text { information services and information to public. }\end{array}$ \\
\hline
\end{tabular}

\subsubsection{Encouragement and facilitation of television programmes in minority languages}

296. The Ministry of Culture - the Media Sector issues an annual tender for cofinancing of projects/programmes in the field of public information and the Provincial Secretariat of Information of AP of Vojvodina issues a tender for equipment, promotion of programme and information to public in minority languages. The public companies founded by the units of local self-government are partially financed from their budgets. The Tables below contain the data on co-financing of regular TV programme broadcasting in minority languages on tender basis, through allocation of funds from the republic and provincial budgets to those television stations broadcasting programmes in minority languages.

\section{Albanian language}

\begin{tabular}{|c|c|c|}
\hline Broadcaster & Duration of TV Programme & $\begin{array}{c}\begin{array}{c}\text { Measures of Encouragement and Facilitation } \\
\text { of Programme Broadcasting }\end{array} \\
\end{array}$ \\
\hline \multicolumn{3}{|l|}{$\begin{array}{l}\text { Multi-lingual Programme } \\
\text { Broadcasting - Public } \\
\text { Companies }\end{array}$} \\
\hline $\begin{array}{l}\text { RTV Bujanovac } \\
\text { TV Bujanovac, } \\
\text { Bujanovac }\end{array}$ & 4 hours daily & $\begin{array}{l}\text { In } 2008 \text { the Ministry of Culture granted } 600,000 \\
\text { dinars for news in Albanian language and in } \\
2009 \text { it granted } 450,000 \text { dinars for contact } \\
\text { programmes in Albanian and Romani languages }\end{array}$ \\
\hline \multicolumn{3}{|l|}{$\begin{array}{l}\text { Broadcasting in Albanian } \\
\text { Language only - Other } \\
\text { Broadcasters }\end{array}$} \\
\hline $\begin{array}{l}\text { RTV Aldi } \\
\text { TV Aldi, } \\
\text { Preševo }\end{array}$ & 24 hours daily & $\begin{array}{l}\text { In } 2009 \text { the Ministry of Culture granted } 480,000 \\
\text { dinars for the Integracija mladih iz opština } \\
\text { Preševo i Bujanovac. }\end{array}$ \\
\hline
\end{tabular}


Bosniak language

\begin{tabular}{|c|c|c|}
\hline Broadcaster & Duration of TV Programme & $\begin{array}{c}\text { Measures of Encouragement and Facilitation } \\
\text { of Programme Broadcasting }\end{array}$ \\
\hline \multicolumn{3}{|l|}{$\begin{array}{l}\text { Multi-lingual Programme } \\
\text { Broadcasting - Public } \\
\text { Companies }\end{array}$} \\
\hline $\begin{array}{l}\text { Regionalna TV Novi Pazar, } \\
\text { Novi Pazar }\end{array}$ & $\begin{array}{l}\text { Due to language similarities } \\
\text { there is no distinguished } \\
\text { programme duration in } \\
\text { Bosniak language }\end{array}$ & $\begin{array}{l}\text { In } 2008 \text { the Ministry of Culture granted } \\
1,000,000 \text { dinars for the Spomenici kulture } \\
\text { sandžačkih Bošnjaka series. }\end{array}$ \\
\hline \multicolumn{3}{|l|}{$\begin{array}{l}\text { Broadcasting in Bosniak } \\
\text { Language only - Public } \\
\text { Companies }\end{array}$} \\
\hline $\begin{array}{l}\text { TV Tutin } \\
\text { Tutin }\end{array}$ & 24 hours daily & $\begin{array}{l}\text { In } 2008 \text { the Ministry of Culture granted } \\
1,000,000 \text { dinars for the Njedra puna zavičaja } \\
\text { programme. }\end{array}$ \\
\hline \multicolumn{3}{|l|}{$\begin{array}{l}\text { Multi-lingual Programme } \\
\text { Broadcasting - Other } \\
\text { Broadcasters }\end{array}$} \\
\hline $\begin{array}{l}\text { TV Forum, } \\
\text { Prijepolje }\end{array}$ & $\begin{array}{l}\text { Due to language similarities } \\
\text { there is no distinguished } \\
\text { programme in Bosniak } \\
\text { language }\end{array}$ & $\begin{array}{l}\text { In } 2009 \text { the Ministry of Culture granted 636,000 } \\
\text { dinars for the Putevima bošnjačke culture. }\end{array}$ \\
\hline
\end{tabular}

\section{Bulgarian language}

\begin{tabular}{|c|l|l|}
\hline Broadcaster & Duration of TV Programme & $\begin{array}{c}\text { Measures of Encouragement and Facilitation } \\
\text { of Programme Broadcasting }\end{array}$ \\
\hline $\begin{array}{l}\text { Multi-lingual Programme } \\
\text { Broadcasting - Public } \\
\text { Companies }\end{array}$ & & \\
\hline$R T V$ Caribrod, & & \\
$T V$ Caribrod, & 3.5 hours daily & $\begin{array}{l}\text { In 2008 the Ministry of Culture granted } \\
1,117,364 \text { dinars for information programmes in } \\
\text { Dimitrovgrad }\end{array}$ \\
& & Bulgarian language. \\
\hline
\end{tabular}

\section{Hungarian language}

\begin{tabular}{|c|c|c|}
\hline Broadcaster & Duration of TV Programme & $\begin{array}{c}\text { Measures of Encouragement and Facilitation } \\
\text { of Programme Broadcasting }\end{array}$ \\
\hline $\begin{array}{l}\text { Broadcasting in Hungarian } \\
\text { Language only - Other } \\
\text { Broadcasters }\end{array}$ & & \\
\hline $\begin{array}{l}\text { TV Mozaik, } \\
\text { Novi Sad }\end{array}$ & 24 hours daily & $\begin{array}{l}\text { In } 2009 \text { the Ministry of Culture granted } 150,000 \\
\text { dinars for daily information programmes; } \\
\text { The Provincial Secretariat of Information granted } \\
2,395,000 \text { dinars in total for equipment, } \\
\text { promotion of programme, information services }\end{array}$ \\
\hline
\end{tabular}




\begin{tabular}{|c|c|c|}
\hline & & and information to public. \\
\hline $\begin{array}{c}\text { RTV Pannon TV Pannon, } \\
\text { Subotica }\end{array}$ & 24 hours daily & $\begin{array}{l}\text { The Provincial Secretariat of Information granted } \\
8,193,000 \text { dinars in total for equipment, } \\
\text { promotion of programme, information services } \\
\text { and information to public. (the funds were } \\
\text { granted for the radio and TV programme at the } \\
\text { level of RTV). }\end{array}$ \\
\hline \multicolumn{3}{|l|}{$\begin{array}{l}\text { Multi-lingual Programme } \\
\text { Broadcasting - Public } \\
\text { Companies }\end{array}$} \\
\hline $\begin{array}{l}\text { RTV Kovačica } \\
T V \text { Kovačica } \\
\text { Kovačica }\end{array}$ & 0.5 hours daily & $\begin{array}{l}\text { The Provincial Secretariat of Information granted } \\
3,996,200 \text { dinars in total for equipment, } \\
\text { promotion of programme, information services } \\
\text { and information to public. }\end{array}$ \\
\hline $\begin{array}{l}\text { RTV Pančevo } \\
\text { TV Pančevo, } \\
\text { Pančevo }\end{array}$ & 0.5 hour weekly & $\begin{array}{l}\text { The Provincial Secretariat of Information granted } \\
3,046,000 \text { dinars in total for equipment, } \\
\text { promotion of programme, information services } \\
\text { and information to public. }\end{array}$ \\
\hline \multicolumn{3}{|l|}{$\begin{array}{l}\text { Multi-lingual Programme } \\
\text { Broadcasting - Other } \\
\text { Broadcasters }\end{array}$} \\
\hline $\begin{array}{c}\text { TV Odžaci, } \\
\text { Odžaci }\end{array}$ & 0.5 hour weekly & $\begin{array}{l}\text { The Provincial Secretariat of Information granted } \\
3,349,000 \text { dinars in total for equipment, } \\
\text { promotion of programme, information services } \\
\text { and information to public. }\end{array}$ \\
\hline $\begin{array}{c}R T V \\
Y U E C O T V \\
\text { Subotica }\end{array}$ & 12 hours daily & $\begin{array}{l}\text { The Provincial Secretariat of Information granted } \\
10,045,000 \text { dinars in total for equipment, } \\
\text { promotion of programme, information services } \\
\text { and information to public. }\end{array}$ \\
\hline
\end{tabular}

Romani language

\begin{tabular}{|c|c|l|}
\hline Broadcaster & Duration of TV Programme & $\begin{array}{c}\text { Measures of Encouragement and Facilitation } \\
\text { of Programme Broadcasting }\end{array}$ \\
\hline $\begin{array}{l}\text { Multi-lingual Programme } \\
\text { Broadcasting - Public } \\
\text { Companies }\end{array}$ & & \\
\hline $\begin{array}{c}\text { RTV Bujanovac } \\
\text { TV Bujanovac, } \\
\text { Bujanovac }\end{array}$ & 1 hours weekly & $\begin{array}{l}\text { In } 2009 \text { the Ministry of Culture granted 450,000 } \\
\text { dinars for the programmes in Albanian and } \\
\text { Romani languages. }\end{array}$ \\
\hline $\begin{array}{c}\text { RTV Valjevo } \\
\text { TV Valjevo, } \\
\text { Valjevo }\end{array}$ & 4hours monthly & $\begin{array}{l}\text { In 2007 the Ministry of Culture granted 360,000 } \\
\text { dinars for the programmes in Romani language } \\
\text { and in 2008 it granted 604,800 dinars for the } \\
\text { information in Romani language. }\end{array}$ \\
\hline $\begin{array}{c}\text { RTV Kruševac } \\
T V \text { Kruševac, } \\
\text { Kruševac }\end{array}$ & 10 minutes daily \\
(news) & $\begin{array}{l}\text { In 2008 the Ministry of Culture granted 310,000 } \\
\text { dinars for the Reč Roma -programme in Romani } \\
\text { language. }\end{array}$ \\
\hline $\begin{array}{c}\text { RTV Krajina } \text { Krajina, } \\
\text { Negotin }\end{array}$ & 0.5 hour weekly & $\begin{array}{l}\text { In 2007 the Ministry of Culture granted 200,000 } \\
\text { for the programmes in Romani language. }\end{array}$ \\
\hline & & The Provincial Secretariat of Information granted \\
\hline
\end{tabular}




\begin{tabular}{|c|c|c|}
\hline $\begin{array}{l}\text { RTV Pančevo } \\
\text { TV Pančevo, } \\
\text { Pančevo }\end{array}$ & 0.5 hour weekly & $\begin{array}{l}3,046,000 \text { dinars in total for equipment, } \\
\text { promotion of programme, information services } \\
\text { and information to public. }\end{array}$ \\
\hline \multicolumn{3}{|c|}{$\begin{array}{l}\text { Multi-lingual Programme } \\
\text { Broadcasting - Other } \\
\text { Broadcasters }\end{array}$} \\
\hline $\begin{array}{l}\text { RTV Nišava } \\
\text { TV Nišava, } \\
\quad \text { Niš }\end{array}$ & $\begin{array}{l}24 \text { hours daily, } \\
\text { major part in Romani }\end{array}$ & $\begin{array}{l}\text { In } 2007 \text { the Ministry of Culture granted } 440,000 \\
\text { dinars for the information programme in Romani } \\
\text { language and in } 2008 \text { it granted 500,000 dinars } \\
\text { for the programmes in the Romani language. }\end{array}$ \\
\hline
\end{tabular}

\section{Romanian language}

\begin{tabular}{|c|c|c|}
\hline Broadcaster & Duration of TV Programme & $\begin{array}{c}\text { Measures of Encouragement and Facilitation } \\
\text { of Programme Broadcasting }\end{array}$ \\
\hline \multicolumn{3}{|l|}{$\begin{array}{l}\text { Multi-lingual Programme } \\
\text { Broadcasting - Public } \\
\text { Companies }\end{array}$} \\
\hline $\begin{array}{l}\text { RTV Kovačica } \\
\text { TV Kovačica, } \\
\text { Kovačica }\end{array}$ & 2.5 hours daily & $\begin{array}{l}\text { The Provincial Secretariat of Information granted } \\
3,996,200 \text { dinars in total for equipment, } \\
\text { promotion of programme, information services } \\
\text { and information to public. }\end{array}$ \\
\hline $\begin{array}{l}\text { RTV Pančevo } \\
\text { TV Pančevo, } \\
\text { Pančevo }\end{array}$ & 1 hour weekly & $\begin{array}{l}\text { The Provincial Secretariat of Information granted } \\
3,046,000 \text { dinars in total for equipment, } \\
\text { promotion of programme, information services } \\
\text { and information to public. }\end{array}$ \\
\hline \multicolumn{3}{|l|}{$\begin{array}{c}\text { Multi-lingual Programme } \\
\text { Broadcasting - Other } \\
\text { Broadcasters }\end{array}$} \\
\hline $\begin{array}{l}\text { RTV Viktorija } \\
\text { TV Viktor, } \\
\text { Vršac } \\
\text { (since 2009) }\end{array}$ & 12 hours daily & $\begin{array}{l}\text { The Provincial Secretariat of Information granted } \\
1,663,000 \text { dinars in total for information services } \\
\text { and information to public. }\end{array}$ \\
\hline
\end{tabular}

\section{Ruthenian language}

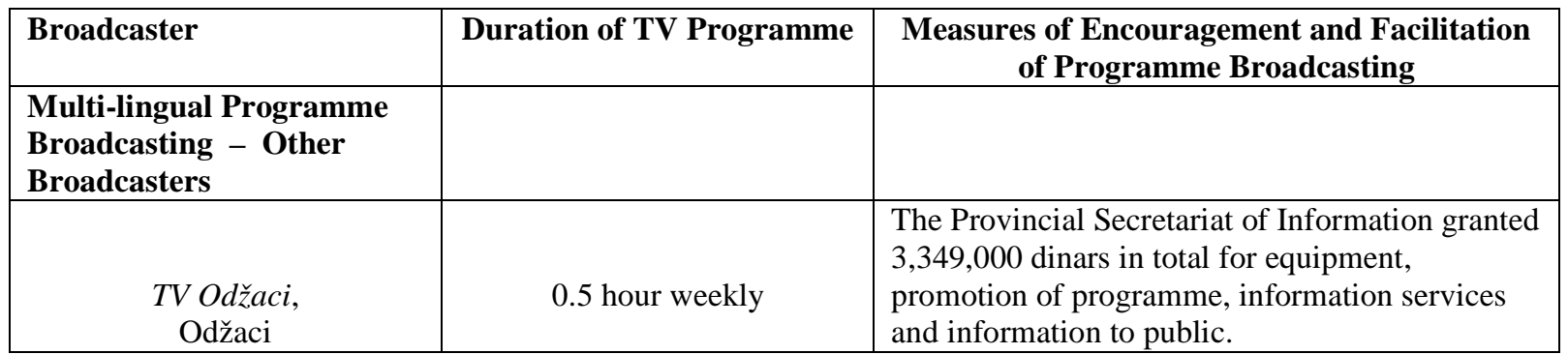

\section{Slovak language}

\begin{tabular}{|l|l|l|}
\hline Broadcaster & Duration of TV Programme & $\begin{array}{c}\text { Measures of Encouragement and Facilitation } \\
\text { of Programme Broadcasting }\end{array}$ \\
\hline Broadcasting in Slovak & & \\
\hline
\end{tabular}




\begin{tabular}{|c|c|c|}
\hline $\begin{array}{l}\text { Language only - Othe } \\
\text { Broadcasters }\end{array}$ & & \\
\hline $\begin{array}{c}\text { TV Petrovac, } \\
\text { Bački Petrovac }\end{array}$ & 24 hours daily & $\begin{array}{l}\text { The Provincial Secretariat of Information granted } \\
3,692,486 \text { dinars in total for equipment, } \\
\text { information services and information to public. }\end{array}$ \\
\hline \multicolumn{3}{|c|}{$\begin{array}{l}\text { Multi-lingual Programme } \\
\text { Broadcasting - Public } \\
\text { Companies }\end{array}$} \\
\hline $\begin{array}{l}\text { RTV Kovačica } \\
\text { TV Kovačica, } \\
\text { Kovačica }\end{array}$ & 2 hours daily & $\begin{array}{l}\text { The Provincial Secretariat of Information granted } \\
3,996,200 \text { dinars in total for equipment, } \\
\text { promotion of programme, information services } \\
\text { and information to public. }\end{array}$ \\
\hline $\begin{array}{l}\text { RTV Pančevo } \\
\text { TV Pančevo, } \\
\text { Pančevo }\end{array}$ & 0.5 hour weekly & $\begin{array}{l}\text { The Provincial Secretariat of Information granted } \\
3,046,000 \text { dinars in total for equipment, } \\
\text { promotion of programme, information services } \\
\text { and information to public. }\end{array}$ \\
\hline \multicolumn{3}{|c|}{$\begin{array}{l}\text { Multi-lingual Programme } \\
\text { Broadcasting - Other } \\
\text { Broadcasters }\end{array}$} \\
\hline $\begin{array}{l}\text { TV Odžaci, } \\
\text { Odžaci }\end{array}$ & 0.5 hour weekly & $\begin{array}{l}\text { The Provincial Secretariat of Information granted } \\
3,349,000 \text { dinars in total for equipment, } \\
\text { promotion of programme, information services } \\
\text { and information to public. }\end{array}$ \\
\hline $\begin{array}{l}\text { Sremska TV, } \\
\text { Šid }\end{array}$ & 0.5 hour weekly & $\begin{array}{l}\text { In } 2007 \text { the Ministry of Culture granted 200,000 } \\
\text { dinars for the Slovački magazine programme. }\end{array}$ \\
\hline
\end{tabular}

\section{Croatian language}

\begin{tabular}{|c|l|l|}
\hline Broadcaster & Duration of TV Programme & $\begin{array}{c}\text { Measures of Encouragement and Facilitation } \\
\text { of Programme Broadcasting }\end{array}$ \\
\hline $\begin{array}{l}\text { Multi-lingual Programme } \\
\text { Broadcasting - Other } \\
\text { Broadcasters }\end{array}$ & \multirow{2}{*}{0.5 hour weekly } & $\begin{array}{l}\text { In } 2007 \text { the Ministry of Culture granted } 127,774 \\
\text { dinars for the programmes in Croatian language; } \\
\text { The Provincial Secretariat of Information granted } \\
10,045,000 \text { dinars in total for equipment, } \\
\text { promotion of programme, information services } \\
\text { and information to public out of which } 200,000 \\
\text { dinars were granted in 2009 for the programme } \\
\text { in Croatian language. }\end{array}$ \\
\hline Subotica
\end{tabular}

297. Since 2009 the Provincial Secretariat of Culture of AP of Vojvodina has been issuing a tender for the grant of funds for the production and broadcasting of television programmes in the field of culture and art in Serbian and minority languages. The tender is issued for TV programme broadcasters - private companies and non-governmental organizations broadcasting programmes that have seats in the territory of AP of Vojvodina. For broadcasting of TV programmes in the field of culture and art in Ruthenian language, the Provincial Secretariat of Culture granted 800,000 dinars for the Sremska televizija from Šid 
for the production and broadcasting of the Rusinski magazin television programme. For broadcasting of TV programmes in culture and art in Hungarian language, the Provincial Secretariat of Culture granted the funds for the production and broadcasting of the following television programmes:

\begin{tabular}{|l|c|r|}
\hline TV Station & $\begin{array}{c}\text { TV Programme in Culture and } \\
\text { Art }\end{array}$ & Granted Funds \\
\hline TV Pannon, Subotica & Vitraž & $330,000.00$ \\
\hline TV Mozaik, Novi Sad & Kultur Ter & $330,000.00$ \\
\hline
\end{tabular}

\subsubsection{Encouragement and facilitation of production and distribution of audio and audio-visual works in minority languages}

298. The Tables below contain examples of encouragement of production and distribution of audio and audio-visual works in minority languages, which had been financially supported from the republic and provincial budgets based on the tenders issued by the Ministry of Culture, the Provincial Secretariat of Information and the Provincial Secretariat of Culture of AP of Vojvodina.

Albanian language

\begin{tabular}{|l|l|l|c|}
\hline \multicolumn{1}{|c|}{ Institution } & \multicolumn{1}{|c|}{ Beneficiary } & \multicolumn{1}{c|}{ Purpose/Programme } & Granted Funds \\
\hline $\begin{array}{l}\text { Ministry of } \\
\text { Culture - Media } \\
\text { Sector }\end{array}$ & $\begin{array}{l}\text { RDU B92, } \\
\text { Belgrade }\end{array}$ & $\begin{array}{l}\text { B92 Internet page in } \\
\text { Albanian and Hungarian } \\
\text { languages }\end{array}$ & $444,000.00$ \\
& $\begin{array}{l}\text { Jug press Regional } \\
\text { Information Agency, } \\
\text { Leskovac }\end{array}$ & $\begin{array}{l}\text { Capacity Building - } \\
\text { establishment of editorial } \\
\text { office in Bulgarian and } \\
\text { activities of editorial offices } \\
\text { in Albanian, Romani and } \\
\text { Serbian languages }\end{array}$ & $1,032,000.00$ \\
& & \\
\hline
\end{tabular}

Bosniak language

\begin{tabular}{|l|l|l|c|}
\hline \multicolumn{1}{|c|}{ Institution } & \multicolumn{1}{|c|}{ Beneficiary } & \multicolumn{1}{c|}{ Purpose/Programme } & Granted Funds \\
\hline Ministry of & National Council of Bosniak & Internet presentation & $440,000.00$ \\
Culture - Media & National Minority, & & \\
Sector & Novi Pazar & & \\
\hline
\end{tabular}

Bulgarian language

\begin{tabular}{|c|c|c|c|}
\hline Institution & Beneficiary & Purpose/Programme & Granted Funds \\
\hline $\begin{array}{l}\text { Ministry of } \\
\text { Culture - Media } \\
\text { Sector }\end{array}$ & $\begin{array}{l}\text { RTV Zaječar, } \\
\text { Zaječar }\end{array}$ & $\begin{array}{l}\text { Govor prekrio jezik, } \\
\text { documentary film on } \\
\text { migration of Bulgarians }\end{array}$ & $807,000.00$ \\
\hline & $\begin{array}{l}\text { Jug press Regional } \\
\text { Information Agency, } \\
\text { Leskovac }\end{array}$ & $\begin{array}{l}\text { Capacity Building - } \\
\text { establishment of editorial } \\
\text { office in Bulgarian and } \\
\text { activities of editorial offices }\end{array}$ & $1,032,000.00$ \\
\hline
\end{tabular}




\begin{tabular}{|c|c|c|}
\hline & & $\begin{array}{l}\text { in Albanian, Romani and } \\
\text { Serbian languages }\end{array}$ \\
\hline
\end{tabular}

\section{Hungarian language}

\begin{tabular}{|c|c|c|c|}
\hline Institution & Beneficiary & Purpose/Programme & Granted Funds \\
\hline $\begin{array}{l}\text { Ministry of } \\
\text { Culture }\end{array}$ & $\begin{array}{l}\text { The Panonija Fund, } \\
\text { Subotica }\end{array}$ & $\begin{array}{l}\text { Naše priče - CD with } \\
\text { Hungarian and Serbian } \\
\text { traditional fairytales }\end{array}$ & $50,000.00$ \\
\hline \multirow{4}{*}{$\begin{array}{l}\text { Ministry of } \\
\text { Culture - Media } \\
\text { Sector }\end{array}$} & $\begin{array}{l}\text { The Večera Šandor Cultural } \\
\text { Club, Вас̌ка Palanka }\end{array}$ & $\begin{array}{l}\text { Dunakanjar, TV } \\
\text { programme in Hungarian }\end{array}$ & $120,000.00$ \\
\hline & $\begin{array}{l}\text { The Magyar Szó, } \\
\text { Novi Sad }\end{array}$ & New web-site & $300,000.00$ \\
\hline & $\begin{array}{l}\text { DB Trade Co, } \\
\text { Bačka Topola }\end{array}$ & $\begin{array}{l}\text { Kikik es Miki and De-arte, } \\
\text { TV programme for children } \\
\text { and youth }\end{array}$ & $979,126.00$ \\
\hline & $R D U$ B92, Belgrade & $\begin{array}{l}\text { B92 Internet page in } \\
\text { Albanian and Hungarian } \\
\text { languages }\end{array}$ & $444,000.00$ \\
\hline $\begin{array}{l}\text { Provincial } \\
\text { Secretariat of } \\
\text { Information }\end{array}$ & $\begin{array}{l}\text { The PostPesimisti Kikinde- } \\
\text { audio and video production/ } \\
\text { VK Radio }\end{array}$ & $\begin{array}{l}\text { Daily news in Hungarian } \\
\text { language }\end{array}$ & $100,000.00$ \\
\hline $\begin{array}{l}\text { Provincial } \\
\text { Secretariat of } \\
\text { Culture }\end{array}$ & $\begin{array}{l}\text { The Kodalj Zoltan Cultural } \\
\text { Club, Bačka Topola }\end{array}$ & $\begin{array}{l}\text { CD of the Caloka Group: } \\
\text { Pastiri sa Potisja }\end{array}$ & $50,000.00$ \\
\hline
\end{tabular}

\section{Romani language}

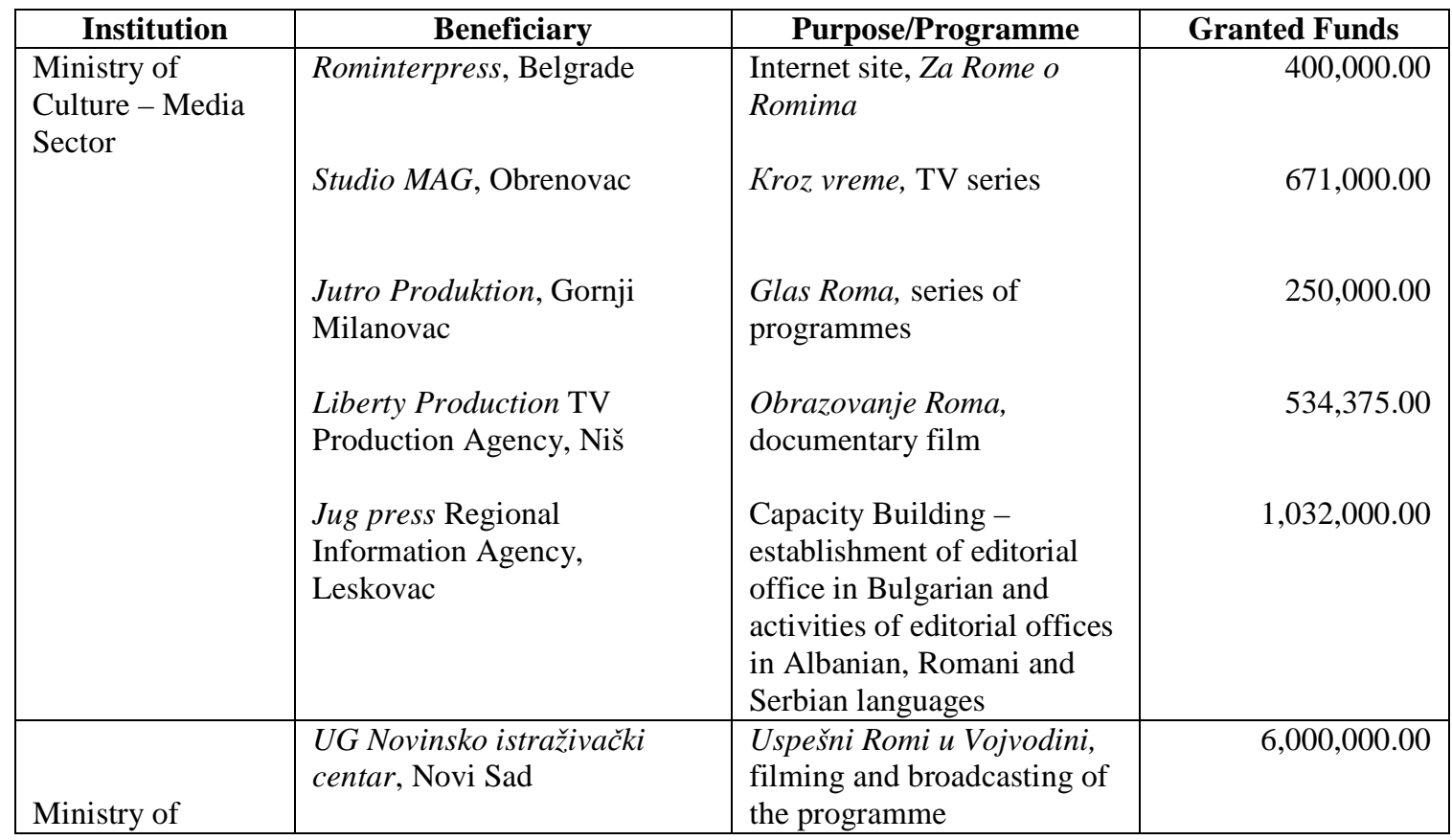




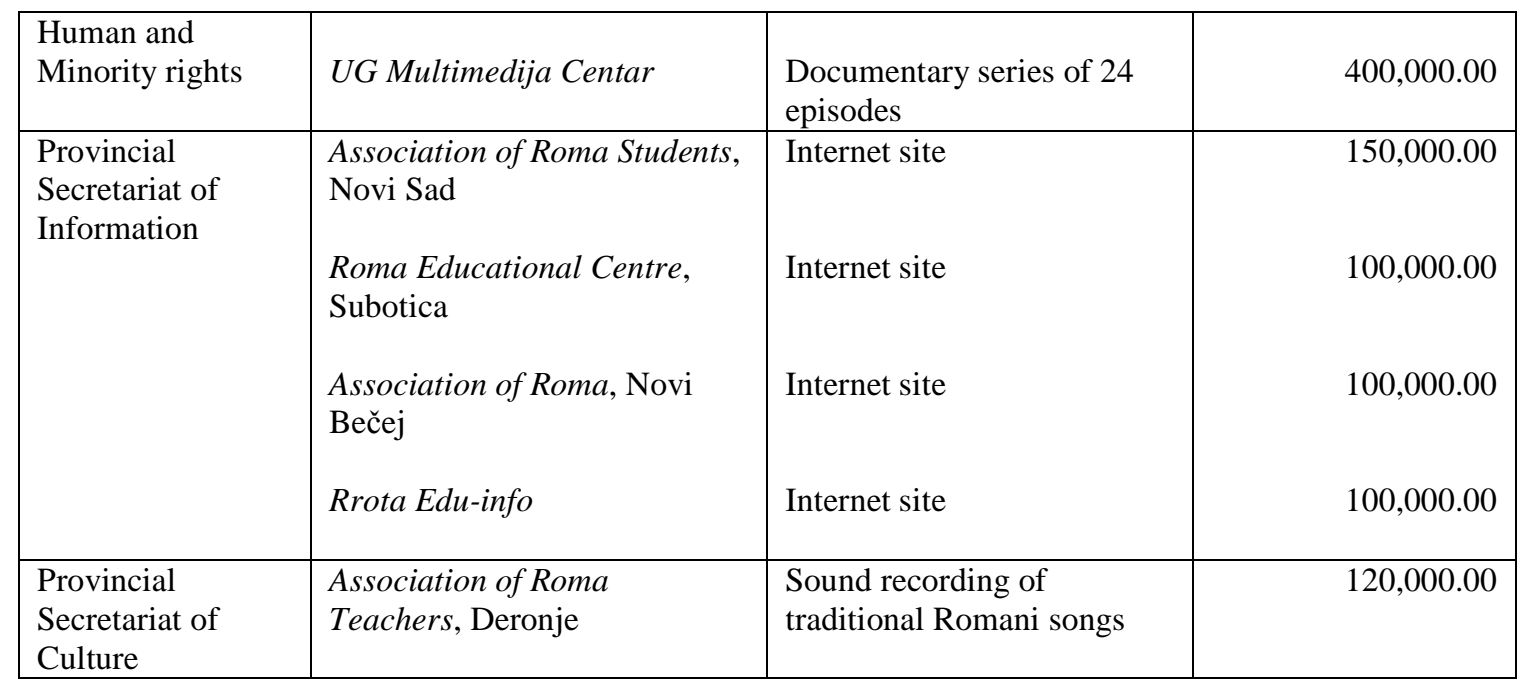

\section{Romanian language}

\begin{tabular}{|c|c|c|c|}
\hline Institution & Beneficiary & Purpose & Granted Funds \\
\hline $\begin{array}{l}\text { Ministry of } \\
\text { Culture - Media } \\
\text { Sector }\end{array}$ & Panovizija, Vršac & $\begin{array}{l}\text { Lutkarsko pozorište, } \\
\text { programme for children }\end{array}$ & $510,000.00$ \\
\hline $\begin{array}{l}\text { Provincial } \\
\text { Secretariat of } \\
\text { Culture }\end{array}$ & $\begin{array}{l}\text { 3. Oktobar Culture Club, } \\
\text { Banatsko Novo Selo } \\
\text { Viktoria Association of } \\
\text { Admirers of Romanian Music, } \\
\text { Vršac }\end{array}$ & $\begin{array}{l}\text { Production of CD with } \\
\text { traditional Romanian music } \\
\text { Sound recording of the } \\
\text { material in Romanian } \\
\text { language of the Stelele } \\
\text { Banatului Group }\end{array}$ & $\begin{array}{l}30,000.00 \\
80,000.00\end{array}$ \\
\hline
\end{tabular}

\section{Ruthenian language}

\begin{tabular}{|l|l|l|c|}
\hline \multicolumn{1}{|c|}{ Institution } & \multicolumn{1}{|c|}{ Beneficiary } & \multicolumn{1}{c|}{ Purpose } & Granted Funds \\
\hline $\begin{array}{l}\text { Ministry of } \\
\text { Culture - Media } \\
\text { Sector }\end{array}$ & $\begin{array}{l}\text { The Ruske Slovo, Newspaper } \\
\text { Agency }\end{array}$ & $\begin{array}{l}\text { Support to Ruthen press } \\
\text { Information Agency }\end{array}$ & $300,000.00$ \\
\hline
\end{tabular}

\section{Slovak language}

\begin{tabular}{|l|l|l|c|}
\hline \multicolumn{1}{|c|}{ Institution } & \multicolumn{1}{|c|}{ Beneficiary } & \multicolumn{1}{c|}{ Purpose } & Granted Funds \\
\hline Ministry of & The Selenča Association for & $\begin{array}{l}\text { 250. жеmвa, TV } \\
\text { Programme }\end{array}$ & $500,000.00$ \\
Culture - Media & Preservation of Culture, \\
Sector & Tradition and Art, Selenča & & \\
\hline
\end{tabular}

\section{Croatian language}

\begin{tabular}{|l|l|l|c|}
\hline \multicolumn{1}{|c|}{ Institution } & \multicolumn{1}{|c|}{ Beneficiary } & \multicolumn{1}{c|}{ Purpose } & Granted Funds \\
\hline $\begin{array}{l}\text { Ministry of } \\
\text { Culture }\end{array}$ & $\begin{array}{l}\text { Croatian Academic Society, } \\
\text { Subotica }\end{array}$ & $\begin{array}{l}\text { Subotički pjesnik Vojislav } \\
\text { Sekelj, short documentary } \\
\text { film-video DVD }\end{array}$ & \\
& & & \\
\hline
\end{tabular}




\begin{tabular}{|c|c|c|c|}
\hline \multirow[t]{5}{*}{$\begin{array}{l}\text { Ministry of } \\
\text { Culture - Media } \\
\text { Sector }\end{array}$} & $\begin{array}{l}\text { The Hrvatska Riječ } \\
\text { Newspaper Agency, Subotica }\end{array}$ & $\begin{array}{l}\text { Hrvatske riječi, daily } \\
\text { electronic issue with audio } \\
\text { and video contents }\end{array}$ & $220,000.00$ \\
\hline & PC Radio Subotica & $\begin{array}{l}\text { Series of radio dramas in } \\
\text { Croatian language }\end{array}$ & $500,000.00$ \\
\hline & $\begin{array}{l}\text { BeneficiaryCro Media, } \\
\text { Subotica }\end{array}$ & $\begin{array}{l}\text { Kronika, } \mathrm{TV} \text { and radio } \\
\text { programmes }\end{array}$ & $712,000.00$ \\
\hline & CroV, Subotica & $\begin{array}{l}\text { Ostanak mladih Hrvata u } \\
\text { sremskim selima }\end{array}$ & $113,000.00$ \\
\hline & & Pišimo jedni drugima & $130,000.00$ \\
\hline \multirow{2}{*}{$\begin{array}{l}\text { Provincial } \\
\text { Secretariat of } \\
\text { Information }\end{array}$} & $\begin{array}{l}3 \text { Video studio/ Radio } \\
\text { Subotica }\end{array}$ & $\begin{array}{l}\text { Slike 20. stoljeća, } \\
\text { documentary radio } \\
\text { programme }\end{array}$ & $200,000.00$ \\
\hline & $\begin{array}{l}\text { Cro Media/ K23- LTV } \\
\text { Subotica, TV Spektar, Sombor } \\
\text { and RTV2, Novi Sad }\end{array}$ & $\begin{array}{l}\text { Video zapisi kulturnog } \\
\text { stvaralaštva Bačke i Srijema }\end{array}$ & $200,000.00$ \\
\hline \multirow{2}{*}{$\begin{array}{l}\text { Provincial } \\
\text { Secretariat of } \\
\text { Culture }\end{array}$} & $\begin{array}{l}\text { Croatian Academic Society, } \\
\text { Subotica }\end{array}$ & Traditional fairytales on CD & $46,000.00$ \\
\hline & The Matija Gubec, Tavankut & $\begin{array}{l}\text { Creation of the Society's } \\
\text { web-site }\end{array}$ & $30,000.00$ \\
\hline
\end{tabular}

\subsubsection{Encouragement or facilitation of establishment and preservation of at least one newspaper in minority languages}

299. 11 informative newspapers in languages of Part III of the Charter are regularly financed from the budgetary funds in the Republic of Serbia (Albanian, Bosniak, Bulgarian, Hungarian, Romani - 2 newspapers, Romanian, Ruthenian, Slovak, Ukrainian and Croatian languages) and 2 newspapers in minority languages of Part II of the Charter (Bunjevac speech and Macedonian language).

300. The Ministry of Culture - the Media Sector, as the competent republic authority, financed: the Perspektiva daily in Albanian language, based on the opinion of the municipalities of Bujanovac and Preševo that this daily expresses the interests of the Albanian national minority; the Sandžačke novine daily in Bosniak language, based on the opinion of the National Council of the Bosniak National Minority that this daily expresses the interests of the national minority concerned; the Romanino Nevipe, founded by the National Council of the Romani National Minority. The entire activities the Bratstvo Newspaper Publishing Association, established by the National Council of the Bulgarian National Minority were financed from the republic budget until 2009 with the amount of 30,000,000 annually. After having noticed disproportion of funds allocated for the newspapers in minority languages and the number of the members of national 
minorities these newspapers are intended to, in 2009 the Ministry of Culture started the preparation of precise criteria for financing of newspapers in minority languages. In accordance with the volume of the newspaper, it was decided to finance the costs of printing, distribution and salaries for a certain number of employees producing newspapers in minority languages. On the grounds of such criteria, the funds for the Bratstvo Newspaper Publishing Association were reduced, namely, the funds were provided from the republic budget to publish a newspaper in Bulgarian language, the Bratstvo, which caused numerous protests by the Bratstvo Newspaper Publishing Association and the National Council of the Bulgarian National Minority. The funds were allocated in the provincial budget to finance the newspapers founded by the national councils of Hungarian, Romani, Romanian, Ruthenian, Slovak, Ukrainian and Croatian national minorities, pursuant to the decision on the transfer of founder's rights to the national councils of the national minorities active in AP of Vojvodina, and 2 informative newspapers in minority languages of Part II of the Charter, which were also founded by the national councils of national minorities.

301. In addition to encouragement, creation and maintenance of at least one newspaper in minority languages by means of subsidies, the competent institutions at the republic and provincial levels issue tenders for co-financing of programmes or projects in the field of public information. The Tables below contain the data on funds granted to the newspapers in minority languages, on both grounds.

\section{Albanian language}

\begin{tabular}{|c|c|c|l|}
\hline Newspaper & Content & Periodical & $\begin{array}{l}\text { Measures of Encouragement } \\
\text { or Facilitation of } \\
\text { Establishment or } \\
\text { Preservation of Newspapers }\end{array}$ \\
\hline $\begin{array}{c}\text { The Perspektiva } \\
\text { Bujanovac }\end{array}$ & informative & weekly & $\begin{array}{l}\text { Subsidies by the Ministry of } \\
\text { Culture }- \text { the in the total } \\
\text { amount of } 18,116,322 \text { dinars. }\end{array}$ \\
\hline $\begin{array}{c}\text { The Diellori, } \\
\text { Bujanovac }\end{array}$ & for children & $\begin{array}{l}\text { In 2007 the Ministry of Culture } \\
- \text { the Media Sector granted } \\
900,000 \text { dinars. }\end{array}$ \\
\hline
\end{tabular}

Bosniak language

\begin{tabular}{|c|l|l|l|}
\hline Newspaper & Content & Periodical & $\begin{array}{l}\text { Measures of Encouragement } \\
\text { or Facilitation of } \\
\text { Establishment or } \\
\text { Preservation of Newspapers }\end{array}$ \\
\hline $\begin{array}{c}\text { The Sandžačke novine, } \\
\text { Novi Pazar }\end{array}$ & informative & weekly & $\begin{array}{l}\text { Subsidies by the Ministry of } \\
\text { Culture }- \text { the in the total } \\
\text { amount of } 14,033,334 \text { dinars. } \\
\text { In 2008 it granted } 1,050,000 \\
\text { dinars for the promotion of } \\
\text { publishing. }\end{array}$ \\
\hline
\end{tabular}

Bulgarian language 


\begin{tabular}{|c|c|c|c|}
\hline Newspaper & Content & Periodical & $\begin{array}{l}\text { Measures of Encouragement } \\
\text { or Facilitation of } \\
\text { Establishment or } \\
\text { Preservation of Newspapers }\end{array}$ \\
\hline \multicolumn{4}{|l|}{$\begin{array}{l}\text { Newspaper Founded by } \\
\text { the National Council of } \\
\text { the Bulgarian National } \\
\text { Minority }\end{array}$} \\
\hline $\begin{array}{c}\text { The Bratstvo, } \\
\text { Niš }\end{array}$ & informative & weekly & $\begin{array}{l}\text { Within the period from } 2007- \\
2008 \text { the Ministry of Culture - } \\
\text { the Media Sector provided } \\
\text { subsidies for the Bratstvo } \\
\text { Newspaper Publishing } \\
\text { Association in the amount of } \\
60,000,000 \text { dinars. In } 2009 \\
\text { subsidies were in the amount of } \\
7,513,303 \text { dinars. In } 2008 \text { the } \\
\text { amount of } 980,000 \text { dinars was } \\
\text { granted to the Bratstvo } \\
\text { Newspaper Publishing } \\
\text { Association to mark its jubilee. }\end{array}$ \\
\hline $\begin{array}{c}\text { The Drugarče, } \\
\text { Niš }\end{array}$ & for children & monthly & $\begin{array}{l}\text { Within the period from } 2007- \\
2008 \text { the Ministry of Culture - } \\
\text { the Media Sector provided } \\
\text { subsidies for the Bratstvo } \\
\text { Newspaper Publishing } \\
\text { Association in the amount of } \\
60,000,000 \text { dinars. }\end{array}$ \\
\hline $\begin{array}{c}\text { The Most, } \\
\text { Niš }\end{array}$ & $\begin{array}{l}\text { magazine in culture, } \\
\text { art and social issues }\end{array}$ & twice a month & $\begin{array}{l}\text { Within the period from } 2007- \\
2008 \text { the Ministry of Culture- } \\
\text { the Media Sector provided } \\
\text { subsidies for the Bratstvo } \\
\text { Newspaper Publishing } \\
\text { Association in the amount of } \\
60,000,000 \text { dinars. }\end{array}$ \\
\hline
\end{tabular}

\section{Hungarian language}

\begin{tabular}{|c|l|l|l|}
\hline Newspaper & Content & Periodical & $\begin{array}{l}\text { Measures of Encouragement } \\
\text { or Facilitation of } \\
\text { Establishment or } \\
\text { Preservation of Newspapers }\end{array}$ \\
\hline $\begin{array}{c}\text { Newspaper Founded by } \\
\text { the National Council of } \\
\text { the Hungarian National } \\
\text { Minority }\end{array}$ & informative & news & $\begin{array}{l}\text { Subsidies by the Provincial } \\
\text { Secretariat of Information were } \\
\text { granted in the total amount of } \\
189,787,000 \text { dinars. }\end{array}$ \\
\hline $\begin{array}{c}\text { The Magyar Szó, } \\
\text { Novi Sad }\end{array}$ & & $\begin{array}{l}\text { In 2007 the Ministry of Culture } \\
- \text { the Media Sector granted } \\
200,000 \text { dinars on tender basis; } \\
\text { Subsidies by the Provincial }\end{array}$ \\
\hline The Jó Pajtás, & school & & \\
\hline
\end{tabular}




\begin{tabular}{|c|c|c|c|}
\hline Novi Sad & & & $\begin{array}{l}\text { Secretariat of Information were } \\
\text { granted in the total amount of } \\
11,392,200 \text { dinars. }\end{array}$ \\
\hline $\begin{array}{c}\text { The Mézéskalács, } \\
\text { Novi Sad }\end{array}$ & for children & monthly & $\begin{array}{l}\text { Subsidies by the Provincial } \\
\text { Secretariat of Information were } \\
\text { granted in the total amount of } \\
4,549,000 \text { dinars. }\end{array}$ \\
\hline $\begin{array}{c}\text { The Képes Ifjúság, } \\
\text { Novi Sad }\end{array}$ & for youth & weekly & $\begin{array}{l}\text { Subsidies by the Provincial } \\
\text { Secretariat of Information were } \\
\text { granted in the total amount of } \\
18,068,400 \text { dinars. }\end{array}$ \\
\hline \multicolumn{4}{|l|}{$\begin{array}{l}\text { Newspaper in Hungarian } \\
\text { Language }\end{array}$} \\
\hline $\begin{array}{l}\text { The Hét Nap, } \\
\text { Subotica }\end{array}$ & family periodical & weekly & $\begin{array}{l}\text { In } 2007 \text { the Ministry of Culture } \\
\text { - the Media Sector granted } \\
85,820 \text { dinars on tender basis } \\
\text { for photo equipment; } \\
\text { Subsidies by the Provincial } \\
\text { Secretariat of Information were } \\
\text { granted in the total amount of } \\
69,565,000 \text { dinars. }\end{array}$ \\
\hline $\begin{array}{c}\text { The Új Kanizsai Újság - } \\
\text { The Kanjiške novine, } \\
\text { Kanjiža }\end{array}$ & informative & weekly & $\begin{array}{l}\text { The Provincial Secretariat of } \\
\text { Information granted } 100,000 \\
\text { dinars in total on tender basis } \\
\text { for information to public. }\end{array}$ \\
\hline $\begin{array}{c}\text { The Muzslyai Újság- } \\
\text { The Mužljanske novine, } \\
\text { Mužlja } \\
\text { (the municipality of } \\
\text { Zrenjanin) }\end{array}$ & $\begin{array}{c}\text { informative } \\
\text { (mainly in Hungarian } \\
\text { language) }\end{array}$ & quarterly & $\begin{array}{l}\text { The Provincial Secretariat of } \\
\text { Information granted } 150,000 \\
\text { dinars in total on tender basis } \\
\text { for information to public. }\end{array}$ \\
\hline $\begin{array}{c}\text { The Családi kör-The } \\
\text { Porodični krug, } \\
\text { Novi Sad }\end{array}$ & family magazine & weekly & $\begin{array}{l}\text { The Provincial Secretariat of } \\
\text { Information granted } 1,249,320 \\
\text { dinars in total on tender basis } \\
\text { for information to public, } \\
\text { improvement of standard and } \\
\text { programme as well as for the } \\
\text { information services. }\end{array}$ \\
\hline $\begin{array}{c}\text { The Kisoroszi Hirmondó } \\
\text { - The Ruskoselski } \\
\text { glasnik, } \\
\text { Rusko Selo } \\
\text { (the municipality of } \\
\text { Kikinda) }\end{array}$ & informative & quarterly & $\begin{array}{l}\text { The Provincial Secretariat of } \\
\text { Information granted } 500,000 \\
\text { dinars in total on tender basis } \\
\text { for information to public. }\end{array}$ \\
\hline $\begin{array}{c}\text { The Temerini Újság- } \\
\text { The Temerinske novine } \\
\text { Temerin }\end{array}$ & informative & weekly & $\begin{array}{l}\text { In } 2007 \text { the Ministry of Culture } \\
\text { - the Media Sector granted } \\
116,160 \text { dinars on tender basis; } \\
\text { The Provincial Secretariat of } \\
\text { Information granted } 100,000 \\
\text { dinars in total on tender basis } \\
\text { for information to public. }\end{array}$ \\
\hline The Tordai Újság - The & informative & monthly & $\begin{array}{l}\text { In } 2007 \text { the Ministry of Culture } \\
\text { - the Media Sector granted } \\
50,000 \text { dinars on tender basis; }\end{array}$ \\
\hline
\end{tabular}




\begin{tabular}{|c|c|c|c|}
\hline $\begin{array}{l}\text { Tordjanske novine, } \\
\text { Torda } \\
\text { (the municipality of } \\
\text { Žitište) }\end{array}$ & $\begin{array}{c}\text { (mainly in Hungarian } \\
\text { language) }\end{array}$ & & $\begin{array}{l}\text { The Provincial Secretariat of } \\
\text { Information granted } 450,000 \\
\text { dinars in total on tender basis } \\
\text { for information to public. }\end{array}$ \\
\hline $\begin{array}{l}\text { The Fecske, } \\
\text { Feketić }\end{array}$ & informative & monthly & $\begin{array}{l}\text { In } 2007 \text { the Ministry of Culture } \\
\text { - the Media Sector granted } \\
50,000 \text { dinars on tender basis }\end{array}$ \\
\hline \multicolumn{4}{|l|}{$\begin{array}{l}\text { Multi-lingual } \\
\text { Newspaper (with pages } \\
\text { in Hungarian language) }\end{array}$} \\
\hline $\begin{array}{c}\text { The Bečejski Mozaik, } \\
\text { Bečej }\end{array}$ & $\begin{array}{c}\text { informative, } \\
3 \text { pages in Hungarian } \\
\text { language }\end{array}$ & weekly & $\begin{array}{l}\text { The Provincial Secretariat of } \\
\text { Information granted } 820,000 \\
\text { dinars in total on tender basis } \\
\text { for technical improvement of } \\
\text { operations and information to } \\
\text { public. }\end{array}$ \\
\hline $\begin{array}{l}\text { The Moj Kovin } \\
(\text { Igaz Szó), Kovin }\end{array}$ & $\begin{array}{c}\text { informative, } \\
12 \text { pages in } \\
\text { Hungarian language }\end{array}$ & monthly & $\begin{array}{l}\text { The Provincial Secretariat of } \\
\text { Information granted } 250,000 \\
\text { dinars in total on tender basis } \\
\text { for information to public. }\end{array}$ \\
\hline $\begin{array}{l}\text { The Zrenjanin, } \\
\text { Zrenjanin }\end{array}$ & $\begin{array}{l}\text { informative, } \\
1 \text { page in Hungarian } \\
\text { language }\end{array}$ & weekly & $\begin{array}{l}\text { The Provincial Secretariat of } \\
\text { Information granted } 1,204,000 \\
\text { dinars in total on tender basis } \\
\text { for technical improvement of } \\
\text { operations and information to } \\
\text { public and for information } \\
\text { services. }\end{array}$ \\
\hline $\begin{array}{c}\text { The Kovinske novine, } \\
\text { Kovin }\end{array}$ & $\begin{array}{c}\text { informative, } \\
0.5 \text { page in } \\
\text { Hungarian language }\end{array}$ & monthly & $\begin{array}{l}\text { The Provincial Secretariat of } \\
\text { Information granted } 100,000 \\
\text { dinars in total on tender basis } \\
\text { for information to public. }\end{array}$ \\
\hline $\begin{array}{c}\text { The Čokanska hronika, } \\
\text { Čoka }\end{array}$ & $\begin{array}{c}\text { informative, } \\
6 \text { pages in Hungarian } \\
\text { language }\end{array}$ & monthly & $\begin{array}{l}\text { The Provincial Secretariat of } \\
\text { Information granted } 133,200 \\
\text { dinars in total on tender basis } \\
\text { for technical improvement of } \\
\text { operations. }\end{array}$ \\
\hline
\end{tabular}

\section{Romani language}

\begin{tabular}{|c|l|l|l|}
\hline Newspaper & Content & Periodical & $\begin{array}{l}\text { Measures of Encouragement } \\
\text { or Facilitation of } \\
\text { Establishment or Preservation } \\
\text { of Newspapers }\end{array}$ \\
\hline $\begin{array}{c}\text { Newspaper Founded by } \\
\text { the National Council of } \\
\text { the Romani National } \\
\text { Minority }\end{array}$ & informative & twice a month & $\begin{array}{l}\text { Secretariat of Information were } \\
\text { granted in the total amount of } \\
\text { 25,718,000 dinars. }\end{array}$ \\
\hline $\begin{array}{c}\text { The Them, } \\
\text { Novi Sad }\end{array}$ & for children & monthly, during & Subsidies by the Provincial \\
\hline The Chavorrengo Them, & & & \\
\hline
\end{tabular}




\begin{tabular}{|c|c|c|l|}
\hline Novi Sad & the school year & $\begin{array}{l}\text { Secretariat of Information were } \\
\text { granted in the total amount of } \\
5,176,000 \text { dinars. }\end{array}$ \\
\hline $\begin{array}{c}\text { The Romanino Nevipe, } \\
\text { Belgrade }\end{array}$ & magazine & monthly & $\begin{array}{l}\text { Subsidies by the Ministry of } \\
\text { Culture }- \text { the Media Sector were } \\
\text { granted in the total amount of } \\
13,000,000 \text { dinars. }\end{array}$ \\
\hline
\end{tabular}

\section{Romanian language}

\begin{tabular}{|c|c|c|c|}
\hline Newspaper & Content & Periodical & $\begin{array}{l}\text { Measures of Encouragement } \\
\text { or Facilitation of } \\
\text { Establishment or Preservation } \\
\text { of Newspapers }\end{array}$ \\
\hline \multicolumn{4}{|l|}{$\begin{array}{l}\text { Newspaper Founded by } \\
\text { the National Council of } \\
\text { the Romanian National } \\
\text { Minority }\end{array}$} \\
\hline $\begin{array}{c}\text { The Libertatea, } \\
\text { Pančevo }\end{array}$ & informative & weekly & $\begin{array}{l}\text { Subsidies by the Provincial } \\
\text { Secretariat of Information were } \\
\text { granted in the total amount of } \\
69,532,000 \text { dinars. }\end{array}$ \\
\hline $\begin{array}{c}\text { The Bucuria Copilor } \\
\text { Pančevo }\end{array}$ & for children & $\begin{array}{l}\text { monthly, during } \\
\text { the school year }\end{array}$ & $\begin{array}{l}\text { Subsidies by the Provincial } \\
\text { Secretariat of Information were } \\
\text { granted in the total amount of } \\
6,311,000 \text { dinars. }\end{array}$ \\
\hline $\begin{array}{l}\text { The Tineretea, } \\
\text { Pančevo }\end{array}$ & for youth & $\begin{array}{l}\text { monthly, during } \\
\text { the school year }\end{array}$ & $\begin{array}{l}\text { Subsidies by the Provincial } \\
\text { Secretariat of Information were } \\
\text { granted in the total amount of } \\
6,311,000 \text { dinars. }\end{array}$ \\
\hline \multicolumn{4}{|l|}{$\begin{array}{l}\text { Magazines in } \\
\text { Romanian Language }\end{array}$} \\
\hline $\begin{array}{c}\text { The Tibiscus, } \\
\text { Uzdin }\end{array}$ & $\begin{array}{c}\text { magazine in culture } \\
\text { and art }\end{array}$ & monthly & $\begin{array}{l}\text { In } 2007 \text { the Ministry of Culture } \\
\text { - the Media Sector granted } \\
50,000 \text { dinars on tender basis. }\end{array}$ \\
\hline \multicolumn{4}{|l|}{$\begin{array}{l}\text { Multi-lingual } \\
\text { Newspapers (with } \\
\text { pages in Romanian } \\
\text { language) }\end{array}$} \\
\hline $\begin{array}{c}\text { The Vršačka kula, } \\
\text { Vršac }\end{array}$ & $\begin{array}{l}\text { informative, } \\
1 \text { page in Romanian } \\
\text { language }\end{array}$ & twice a month & $\begin{array}{l}\text { The Provincial Secretariat of } \\
\text { Information granted } 150,000 \\
\text { dinars in total on tender basis for } \\
\text { information services. }\end{array}$ \\
\hline $\begin{array}{c}\text { The Zrenjanin, } \\
\text { Zrenjanin }\end{array}$ & $\begin{array}{c}\text { informative, } \\
1 \text { page monthly in } \\
\text { Romanian language }\end{array}$ & weekly & $\begin{array}{l}\text { The Provincial Secretariat of } \\
\text { Information granted } 1,204,000 \\
\text { dinars in total on tender basis for } \\
\text { technical improvement of } \\
\text { operations and information to } \\
\text { public and for information } \\
\text { services. }\end{array}$ \\
\hline $\begin{array}{c}\text { The Kovinske novine, } \\
\text { Kovin }\end{array}$ & $\begin{array}{c}\text { informative, } \\
0.5 \text { page in } \\
\text { Romanian language }\end{array}$ & monthly & $\begin{array}{l}\text { The Provincial Secretariat of } \\
\text { Information granted } 100,000 \\
\text { dinars in total on tender basis for } \\
\text { information to public. }\end{array}$ \\
\hline
\end{tabular}




\begin{tabular}{|l|l|l|l|}
\hline & & & \\
\hline
\end{tabular}

\section{Ruthenian language}

\begin{tabular}{|c|c|c|c|}
\hline Newspaper & Content & Periodical & $\begin{array}{l}\text { Measures of Encouragement } \\
\text { or Facilitation of } \\
\text { Establishment or Preservation } \\
\text { of Newspapers }\end{array}$ \\
\hline \multicolumn{4}{|l|}{$\begin{array}{l}\text { Newspaper Founded by } \\
\text { the National Council of } \\
\text { the Ruthenian National } \\
\text { Minority }\end{array}$} \\
\hline $\begin{array}{c}\text { The Ruske slovo, } \\
\text { Novi Sad }\end{array}$ & informative & weekly & $\begin{array}{l}\text { Subsidies by the Provincial } \\
\text { Secretariat of Information were } \\
\text { granted in the total amount of } \\
69,532,000 \text { dinars . }\end{array}$ \\
\hline $\begin{array}{c}\text { The Zagradtka, } \\
\text { Novi Sad }\end{array}$ & for children & monthly & $\begin{array}{l}\text { Subsidies by the Provincial } \\
\text { Secretariat of Information were } \\
\text { granted in the total amount of } \\
6,311,000 \text { dinars . }\end{array}$ \\
\hline $\begin{array}{l}\text { The Мaк, } \\
\text { Novi Sad }\end{array}$ & for youth & monthly & $\begin{array}{l}\text { Subsidies by the Provincial } \\
\text { Secretariat of Information were } \\
\text { granted in the total amount of } \\
25,718,000 \text { dinars. }\end{array}$ \\
\hline
\end{tabular}

\section{Slovak language}

\begin{tabular}{|c|c|c|c|}
\hline Newspaper & Content & Periodical & $\begin{array}{l}\text { Measures of Encouragement } \\
\text { or Facilitation of } \\
\text { Establishment or Preservation } \\
\text { of Newspapers }\end{array}$ \\
\hline \multicolumn{4}{|l|}{$\begin{array}{l}\text { Newspaper Founded by } \\
\text { the National Council of } \\
\text { the Slovak National } \\
\text { Minority }\end{array}$} \\
\hline $\begin{array}{c}\text { The Hlas L'udu, } \\
\text { Novi Sad }\end{array}$ & informative & weekly & $\begin{array}{l}\text { Subsidies by the Provincial } \\
\text { Secretariat of Information were } \\
\text { granted in the total amount of } \\
70,188,000 \text { dinars. }\end{array}$ \\
\hline $\begin{array}{l}\text { The Vzlet, } \\
\text { Novi Sad }\end{array}$ & for youth & monthly & $\begin{array}{l}\text { Subsidies by the Provincial } \\
\text { Secretariat of Information were } \\
\text { granted in the total amount of } \\
6,300,000 \text { dinars. }\end{array}$ \\
\hline $\begin{array}{c}\text { The Zornička, } \\
\text { Novi Sad }\end{array}$ & for children & monthly & $\begin{array}{l}\text { Subsidies by the Provincial } \\
\text { Secretariat of Information were } \\
\text { granted in the total amount of } \\
4,941,000 \text { dinars. }\end{array}$ \\
\hline \multicolumn{4}{|l|}{$\begin{array}{l}\text { Multi-lingual } \\
\text { Newspapers (with } \\
\text { pages in Slovak } \\
\text { language) }\end{array}$} \\
\hline The Zrenjanin, & informative, & weekly & $\begin{array}{l}\text { The Provincial Secretariat of } \\
\text { Information granted } 1,204,000 \\
\text { dinars in total on tender basis for }\end{array}$ \\
\hline
\end{tabular}




\begin{tabular}{|l|l|l|l|}
\hline Zrenjanin & $\begin{array}{l}\text { 1 page monthly in } \\
\text { Slovak language }\end{array}$ & $\begin{array}{l}\text { technical improvement of } \\
\text { operations and information to } \\
\text { public and for information } \\
\text { services. }\end{array}$ \\
\hline
\end{tabular}

\section{Ukrainian language}

\begin{tabular}{|c|l|l|l|}
\hline Newspaper & Content & Periodical & $\begin{array}{l}\text { Measures of Encouragement } \\
\text { or Facilitation of } \\
\text { Establishment or Preservation } \\
\text { of Newspapers }\end{array}$ \\
\hline $\begin{array}{c}\text { Newspaper Founded by } \\
\text { the National Council of } \\
\text { the Ukrainian National } \\
\text { Minority }\end{array}$ & informative & monthly & $\begin{array}{l}\text { Subsidies by the Provincial } \\
\text { Secretariat of Information were } \\
\text { granted in the total amount of } \\
7,857,400 \text { dinars. }\end{array}$ \\
\hline $\begin{array}{c}\text { The P̈̈не слово, } \\
\text { Кula }\end{array}$ & for children & monthly & $\begin{array}{l}\text { Subsidies by the Provincial } \\
\text { Secretariat of Information were } \\
\text { granted in the total amount of } \\
2,734,000 \text { dinars. }\end{array}$ \\
\hline $\begin{array}{c}\text { The Соловейко, } \\
\text { Nоvi Sad }\end{array}$ & & & \\
\hline $\begin{array}{c}\text { Magazines in } \\
\text { Ukrainian Language }\end{array}$ & & & $\begin{array}{l}\text { In } 2007 \text { the Ministry of Culture } \\
\text { the Media Sector granted } \\
100,000 \text { dinars on tender basis }\end{array}$ \\
\hline $\begin{array}{c}\text { The Украјинске слово, } \\
\text { Novi Sad }\end{array}$ & social magazine & &
\end{tabular}

\section{Croatian language}

\begin{tabular}{|c|c|c|c|}
\hline Newspaper & Content & Periodical & $\begin{array}{l}\text { Measures of Encouragement } \\
\text { or Facilitation of } \\
\text { Establishment or Preservation } \\
\text { of Newspapers }\end{array}$ \\
\hline \multicolumn{4}{|l|}{$\begin{array}{l}\text { Newspaper Founded by } \\
\text { the National Council of } \\
\text { the Croatian National } \\
\text { Minority }\end{array}$} \\
\hline $\begin{array}{c}\text { The Hrvatska riječ, } \\
\text { Subotica }\end{array}$ & informative & weekly & $\begin{array}{l}\text { Subsidies by the Provincial } \\
\text { Secretariat of Information were } \\
\text { granted in the total amount of } \\
58,339,000 \text { dinars }\end{array}$ \\
\hline $\begin{array}{l}\text { The Hrcko, } \\
\text { Subotica }\end{array}$ & $\begin{array}{l}\text { supplement for } \\
\text { children }\end{array}$ & monthly & $\begin{array}{l}\text { Subsidies by the Provincial } \\
\text { Secretariat of Information were } \\
\text { granted in the total amount of } \\
6,300,000 \text { dinars . }\end{array}$ \\
\hline The Kužiš?! & for youth & monthly & $\begin{array}{l}\text { In } 2007 \text { the Ministry of Culture } \\
\text { - the Media Sector granted } \\
\text { 200,000 dinars on tender basis to } \\
\text { Newspaper Publishing } \\
\text { Association for youth } \\
\text { newspaper; }\end{array}$ \\
\hline
\end{tabular}




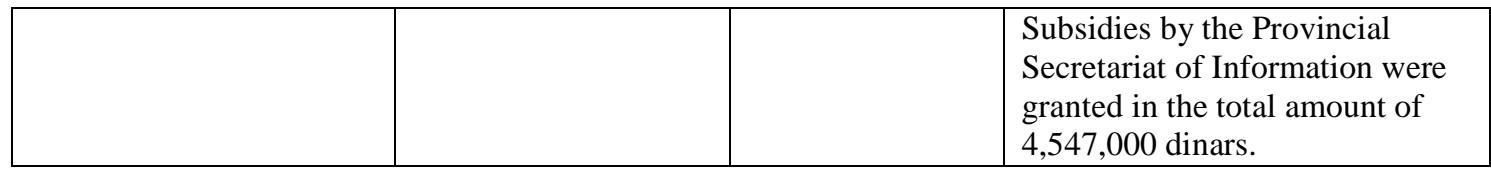

302. In addition to the support to the projects in the field of public information in minority languages, the state also co-finances magazines and publications in the field of art and culture in minority languages. On tender basis the Ministry of Culture co-finances projects/programmes the quality of which contributes to the development and presentation of art and culture of national minorities, while the Provincial Secretariat of Culture of AP of Vojvodina finances, on tender basis, magazines in the field of culture, literature and art of special importance for the development of culture and art in AP of Vojvodina and magazines for children in minority languages. The Tables below contain the data about financial support to projects and magazines in minority languages.

\section{Bosniak language}

\begin{tabular}{|l|l|l|}
\hline \multicolumn{1}{|c|}{ Beneficiary } & Project /Magazine & Measures of Encouragement \\
\hline $\begin{array}{l}\text { The National Council of the } \\
\text { Bosniak National Minority, } \\
\text { Novi Pazar }\end{array}$ & The Bošnjačka riječ & $\begin{array}{l}\text { The Ministry of Culture granted } \\
600,000 \text { dinars. }\end{array}$ \\
\hline
\end{tabular}

\section{Bulgarian language}

\begin{tabular}{|c|c|l|}
\hline Beneficiary & Project & Granted Funds \\
\hline \multirow{3}{*}{ The Link Design Studio, Pirot } & $\begin{array}{c}\text { Preservation of cultural tradition of } \\
\text { the Stara Planina villages in the } \\
\text { territory of the Republic of Serbia } \\
\text { (the municipalities of } \\
\text { Dimitrovgrad, Knjaževac and } \\
\text { Pirot) }\end{array}$ & $\begin{array}{l}\text { The Ministry of Culture granted } \\
80,000 \text { dinars. }\end{array}$ \\
& & \\
\hline
\end{tabular}

\section{Hungarian language}

\begin{tabular}{|c|c|c|}
\hline Beneficiary/ Publisher & Project /Magazine & Granted Funds \\
\hline $\begin{array}{l}\text { The Stanišić Printing House, } \\
\text { Вас̌ка Palanka }\end{array}$ & Akácos Út (The Aleja bagrema) & $\begin{array}{l}\text { The Provincial Secretariat of } \\
\text { Culture granted 50,000 dinars. }\end{array}$ \\
\hline $\begin{array}{l}\text { The Sziveri János Art Scene, } \\
\text { Mužlja }\end{array}$ & The Sikoly (The Krik), magazine & $\begin{array}{l}\text { The Ministry of Culture granted } \\
50,000 \text { dinars; } \\
\text { The Provincial Secretariat of } \\
\text { Culture granted } 182,000 \text { dinars . }\end{array}$ \\
\hline The Forum, Novi Sad & $\begin{array}{l}\text { The Hid (The Most), } \\
\text { magazine in literature and art } \\
\text { The Létünk (Stvarnost) }{ }^{5}\end{array}$ & $\begin{array}{l}\text { The Ministry of Culture granted } \\
500,000 \text { dinars; The Provincial } \\
\text { Secretariat of Culture granted } \\
352,000 \text { dinars. } \\
\text { The Ministry of Culture granted }\end{array}$ \\
\hline
\end{tabular}

\footnotetext{
${ }^{4}$ Since 2009 the magazine is financed within the regular activities of the Forum, Publishing Company.
} 


\begin{tabular}{|c|c|c|}
\hline & $\begin{array}{l}\text { magazine in society, science and } \\
\text { culture }\end{array}$ & $\begin{array}{l}220,000 \text { dinars; } \\
\text { The Provincial Secretariat of } \\
\text { Culture granted } 208,000 \text { dinars. }\end{array}$ \\
\hline $\begin{array}{l}\text { The Collegium of University } \\
\text { Education of the Vojvodina } \\
\text { Hungarians, Novi Sad }\end{array}$ & DNS & $\begin{array}{l}\text { The Provincial Secretariat of } \\
\text { Culture granted 310,500 dinars. }\end{array}$ \\
\hline $\begin{array}{l}\text { Department of Hungarian } \\
\text { Language and Literature, the } \\
\text { Faculty of Philosophy, Novi } \\
\text { Sad }\end{array}$ & $\begin{array}{c}\text { Hungarológiai Közlemények } \\
\text { (Information of Hungarian Studies) }\end{array}$ & $\begin{array}{l}\text { The Provincial Secretariat of } \\
\text { Culture granted } 158,500 \text { dinars. }\end{array}$ \\
\hline The Lajoš Sabo, Subotica & The Bačopcaz, magazine & $\begin{array}{l}\text { The Ministry of Culture granted } \\
50,000 \text { dinars. }\end{array}$ \\
\hline $\begin{array}{l}\text { The Symposion, Association of } \\
\text { Citizens, Subotica }\end{array}$ & Symposion & $\begin{array}{l}\text { The Ministry of Culture granted } \\
230.000 \text { dinars; The Provincial } \\
\text { Secretariat of Culture granted } \\
264,500 \text { dinars. }\end{array}$ \\
\hline $\begin{array}{l}\text { The Zobodka, Association of } \\
\text { Citizens, Subotica }\end{array}$ & $\ddot{U}$ zenet & $\begin{array}{l}\text { The Provincial Secretariat of } \\
\text { Culture granted } 264,500 \text { dinars. }\end{array}$ \\
\hline $\begin{array}{l}\text { The Bácsország, Association of } \\
\text { Vojvodina for Familiarization } \\
\text { with Homeland, } \\
\text { Subotica }\end{array}$ & $\begin{array}{l}\text { The Bácsország, } \\
\text { magazine for familiarization with } \\
\text { homeland }\end{array}$ & $\begin{array}{l}\text { The Provincial Secretariat of } \\
\text { Culture granted } 368,500 \text { dinars. }\end{array}$ \\
\hline $\begin{array}{l}\text { Social Cultural Organization of } \\
\text { the Aracs Village, Subotica }\end{array}$ & $\begin{array}{c}\text { Aracs, } \\
\text { a Délvidéki Magyarság Közéleti } \\
\text { Folyóirata }\end{array}$ & $\begin{array}{l}\text { The Provincial Secretariat of } \\
\text { Culture granted } 152,000 \text { dinars. }\end{array}$ \\
\hline Club of Torda Citizens, Torda & $\begin{array}{c}\text { The Tordai Újság - The Torđanske } \\
\text { novine }\end{array}$ & $\begin{array}{l}\text { The Provincial Secretariat of } \\
\text { Culture granted } 80,000 \text { dinars. }\end{array}$ \\
\hline $\begin{array}{l}\text { Amicus -Jó Pajtás Kft, Novi } \\
\text { Sad }\end{array}$ & $\begin{array}{l}\text { The Mezéskalács, } \\
\text { magazine for children } \\
\text { The Jó Pajtás, } \\
\text { magazine for children }\end{array}$ & $\begin{array}{l}\text { The Provincial Secretariat of } \\
\text { Culture granted 190,500 dinars. } \\
\text { The Provincial Secretariat of } \\
\text { Culture granted 180,500 dinars. }\end{array}$ \\
\hline $\begin{array}{l}\text { Magyar Szó Kft, } \\
\text { Novi Sad }\end{array}$ & $\begin{array}{l}\text { The Képes Ifjúság, } \\
\text { magazine for children }\end{array}$ & $\begin{array}{l}\text { The Provincial Secretariat of } \\
\text { Culture granted } 150,500 \text { dinars. }\end{array}$ \\
\hline
\end{tabular}

\section{Romani language}

\begin{tabular}{|c|c|l|}
\hline \multicolumn{1}{|c|}{ Publisher } & Magazine & \multicolumn{1}{c|}{ Granted Funds } \\
\hline $\begin{array}{l}\text { Association of Romani } \\
\text { Teachers of Vojvodina, Deronje }\end{array}$ & $\begin{array}{c}\text { The Romologija, } \\
\text { magazine in science, art and social } \\
\text { issues of Roma }\end{array}$ & $\begin{array}{l}\text { The Provincial Secretariat of } \\
\text { Culture granted 129,000 dinars. }\end{array}$ \\
\hline
\end{tabular}

\section{Romanian language}

\begin{tabular}{|l|c|l|}
\hline \multicolumn{1}{|c|}{ Beneficiary/Publisher } & Project /Magazine & Granted Funds \\
\hline Association for Romanian & Limba Romanina & The Ministry of Culture granted \\
Language of Vojvodina, Vršac & & 50,000 dinars. \\
\hline
\end{tabular}

${ }_{6}^{5}$ Since 2009 the magazine is financed within the regular activities of the Forum, Publishing Company.

${ }^{6}$ Since 2009 the magazine is published by the Magyar Szó Kft .

${ }^{7}$ Since 2009 the magazine is published by the Magyar Szó Kft. 


\begin{tabular}{|c|c|c|}
\hline $\begin{array}{l}\text { Romanian Association for } \\
\text { Ethnography and Folklore, } \\
\text { Novi Sad }\end{array}$ & $\begin{array}{c}\text { The Traditia, } \\
\text { magazine in ethnography and } \\
\text { folklore }\end{array}$ & $\begin{array}{l}\text { The Provincial Secretariat of } \\
\text { Culture granted } 143,500 \text { dinars. }\end{array}$ \\
\hline \multirow{3}{*}{$\begin{array}{l}\text { The Libertatea, Newspaper } \\
\text { Publishing Association, } \\
\text { Pančevo }\end{array}$} & $\begin{array}{c}\text { The Lumina, } \\
\text { magazine in literature, art and } \\
\text { culture }\end{array}$ & $\begin{array}{l}\text { The Provincial Secretariat of } \\
\text { Culture granted } 357,000 \text { dinars. }\end{array}$ \\
\hline & $\begin{array}{l}\text { The Bucuria Copilor, } \\
\text { magazine for children }\end{array}$ & $\begin{array}{l}\text { The Provincial Secretariat of } \\
\text { Culture granted } 150.500 \text { dinars }\end{array}$ \\
\hline & $\begin{array}{l}\text { The Tineretea, } \\
\text { magazine for youth }\end{array}$ & $\begin{array}{l}\text { The Provincial Secretariat of } \\
\text { Culture granted } 131,000 \text { dinars. }\end{array}$ \\
\hline $\begin{array}{l}\text { The Tibiscus, Literature and Art } \\
\text { Association, } \\
\text { Uzdin }\end{array}$ & $\begin{array}{c}\text { The Tibiscus, } \\
\text { magazine in culture and art }\end{array}$ & $\begin{array}{l}\text { The Provincial Secretariat of } \\
\text { Culture granted 114,000 dinars. }\end{array}$ \\
\hline
\end{tabular}

\section{Ruthenian language}

\begin{tabular}{|c|c|c|}
\hline Publisher & Magazine & Granted Funds \\
\hline $\begin{array}{l}\text { The Руске слово, Newspaper } \\
\text { Publishing Association } \\
\text { Novi Sad }\end{array}$ & $\begin{array}{c}\text { Thе Шветлоси, } \\
\text { magazine in literature, culture and } \\
\text { art } \\
\text { The Заградка, } \\
\text { magazine for children } \\
\text { Тhе МАК (Младост, Активност, } \\
\text { Kреативност), } \\
\text { cultural-politic magazine }\end{array}$ & $\begin{array}{l}\text { The Provincial Secretariat of } \\
\text { Culture granted 357,000 dinars. } \\
\text { The Provincial Secretariat of } \\
\text { Culture granted 150,500 dinars. } \\
\text { The Provincial Secretariat of } \\
\text { Culture granted 131,000 dinars. }\end{array}$ \\
\hline $\begin{array}{l}\text { Association for Ruthenian } \\
\text { Language, Literature and } \\
\text { Culture, Novi Sad }\end{array}$ & $\begin{array}{l}\text { The Studia Ruthenica, } \\
\text { collection of works }\end{array}$ & $\begin{array}{l}\text { The Provincial Secretariat of } \\
\text { Culture granted } 84,500 \text { dinars. }\end{array}$ \\
\hline Multilingual Magazines & & \\
\hline $\begin{array}{l}\text { Association for Ruthenian } \\
\text { Language, Literature and } \\
\text { Culture, Novi Sad and Cultural } \\
\text { Centre of Vrbas, Vrbas }\end{array}$ & $\begin{array}{c}\text { The Ерато над } \\
\text { Куиуром/Коиуром, } \\
\text { In Ruthenian an Serbian languages }\end{array}$ & $\begin{array}{l}\text { The Provincial Secretariat of } \\
\text { Culture granted } 65,000 \text { dinars. }\end{array}$ \\
\hline
\end{tabular}

\section{Slovak language}

\begin{tabular}{|l|c|l|}
\hline \multicolumn{1}{|c|}{ Beneficiary/Publisher } & Project /Magazine & Granted Funds \\
\hline $\begin{array}{l}\text { Slovak Publishing Centre, } \\
\text { Bački Petrovac }\end{array}$ & $\begin{array}{c}\text { The Nový život, } \\
\text { Magazine in literature and culture }\end{array}$ & $\begin{array}{l}\text { The Ministry of Culture granted } \\
\text { 200,000 dinars; The Provincial } \\
\text { Secretariat of Culture granted } \\
357,000 \text { dinars. }\end{array}$ \\
\hline $\begin{array}{l}\text { The Kultura Printing House, } \\
\text { Bački Petrovac }\end{array}$ & $\begin{array}{l}\text { The Rovina, } \\
\text { family magazine }\end{array}$ & $\begin{array}{l}\text { The Provincial Secretariat of } \\
\text { Culture granted 145,500 dinars. }\end{array}$ \\
& $\begin{array}{l}\text { The Zornička, } \\
\text { magazine for children }\end{array}$ & $\begin{array}{l}\text { The Provincial Secretariat of } \\
\text { Culture granted 150,500 dinars. }\end{array}$ \\
\hline & The Obzory, & $\begin{array}{l}\text { The Provincial Secretariat of } \\
\text { Culture granted 110,500 dinars. }\end{array}$ \\
\hline
\end{tabular}




\begin{tabular}{|l|c|l|}
\hline $\begin{array}{l}\text { Publishing Association, Novi } \\
\text { Sad }\end{array}$ & $\begin{array}{c}\text { The Vzlet, } \\
\text { magazine for youth }\end{array}$ & $\begin{array}{l}\text { The Provincial Secretariat of } \\
\text { Culture granted } 131,000 \text { dinars. }\end{array}$ \\
\hline $\begin{array}{l}\text { The Faculty of Philosophy }- \\
\text { Department of Slovak Studies, } \\
\text { Novi Sad }\end{array}$ & Traf & $\begin{array}{l}\text { The Provincial Secretariat of } \\
\text { Culture granted } 40,000 \text { dinars. }\end{array}$ \\
\hline
\end{tabular}

\section{Ukrainian language}

\begin{tabular}{|c|c|c|}
\hline Beneficiary/Publisher & Project /Magazine & Granted Funds \\
\hline $\begin{array}{l}\text { The Pидне слово, Newspaper } \\
\text { Publishing Association, } \\
\text { Kula }\end{array}$ & $\begin{array}{c}\text { The Слово (The Reč), } \\
\text { magazine in culture, literature and } \\
\text { art }\end{array}$ & $\begin{array}{l}\text { The Provincial Secretariat of } \\
\text { Culture granted 70,000 dinars. }\end{array}$ \\
\hline $\begin{array}{l}\text { The Просвита, Association for } \\
\text { Ukrainian Language, Literature } \\
\text { and Culture, Novi Sad }\end{array}$ & $\begin{array}{l}\text { Українсъке слово- } \\
\text { Украјинске слово }\end{array}$ & $\begin{array}{l}\text { The Ministry of Culture granted } \\
100,000 \text { dinars; } \\
\text { The Provincial Secretariat of } \\
\text { Culture granted } 39,000 \text { dinars. }\end{array}$ \\
\hline $\begin{array}{l}\text { The National Council of the } \\
\text { Ukrainian National Minority/ } \\
\text { The Puдне слово, Newspaper } \\
\text { Publishing Association, Novi } \\
\text { Sad }\end{array}$ & $\begin{array}{c}\text { The Соловејко, } \\
\text { magazine for children }\end{array}$ & $\begin{array}{l}\text { The Provincial Secretariat of } \\
\text { Culture granted 106,500 dinars. }\end{array}$ \\
\hline
\end{tabular}

\section{Croatian language}

\begin{tabular}{|l|c|l|}
\hline \multicolumn{1}{|c|}{ Beneficiary/Publisher } & Project /Magazine & Granted Funds \\
\hline $\begin{array}{l}\text { The Croatian Academic } \\
\text { Society, Subotica }\end{array}$ & $\begin{array}{c}\text { The Leksikon podunavskih Hrvata- } \\
\text { Bunjevaca } \text { S Škaca (Book IX) }\end{array}$ & $\begin{array}{l}\text { The Ministry of Culture granted } \\
130,000 \text { dinars. }\end{array}$ \\
\hline & $\begin{array}{c}\text { The Klasije naših ravni, } \\
\text { magazine in literature, art and } \\
\text { science }\end{array}$ & $\begin{array}{l}\text { The Ministry of Culture granted } \\
200,000 \text { dinars; } \\
\text { The Provincial Secretariat of } \\
\text { Culture granted 357,000 dinars.. }\end{array}$ \\
$\begin{array}{l}\text { The Hrvatska riječ, Newspaper } \\
\begin{array}{l}\text { Publishing Association, } \\
\text { Subotica }\end{array}\end{array}$ & $\begin{array}{c}\text { The Hrcko, } \\
\text { magazine for children }\end{array}$ & $\begin{array}{l}\text { The Provincial Secretariat of } \\
\text { Culture granted } 102,000 \text { dinars.. }\end{array}$ \\
& The Kužišs! & $\begin{array}{l}\text { The Provincial Secretariat of } \\
\text { Culture granted 92,000 dinars. }\end{array}$ \\
\hline
\end{tabular}

303. In order to encourage and promote multi-linguistic character of Vojvodina, the Provincial Secretariat of Culture of AP of Vojvodina also co-finances, on tender basis, magazines in the field of culture, literature and art in several languages. The Table below contains examples of such support.

\begin{tabular}{|l|c|r|}
\hline \multicolumn{1}{|c|}{ Publisher } & Magazine & Granted Funds \\
\hline $\begin{array}{l}\text { Association for Ruthenian Language, } \\
\text { Literature and Culture, Novi Sad and } \\
\text { the Cultural Centre of Vrbas, Vrbas }\end{array}$ & $\begin{array}{c}\text { The Eрато над Куиуром/Коиуром, } \\
\text { in Ruthenian and Serbian languages }\end{array}$ & $65,000.00$ \\
\hline $\begin{array}{l}\text { The Zetna, Association of Citizens, } \\
\text { Senta }\end{array}$ & $\begin{array}{c}\text { The Zetna, } \\
\text { Magazin a vulkán alatt - Магазин под } \\
\text { вулканом, } \\
\text { in Hungarian and Serbian languages }\end{array}$ & $119,000.00$ \\
\hline The KPZ Sečanj, Sečanj & The Огледало - the Oglinda, & $134,000.00$ \\
\hline
\end{tabular}




\begin{tabular}{|l|c|c|}
\hline & $\begin{array}{c}\text { in Hungarian, Romanian and Serbian } \\
\text { languages }\end{array}$ & \\
\hline Regional, Subotica & $\begin{array}{c}\text { The Regional, } \\
\text { magazine in culture, }\end{array}$ & $132,000.00$ \\
& $\begin{array}{c}\text { in Hungarian, Serbian and Croatian } \\
\text { languages }\end{array}$ & $45,000.00$ \\
\hline $\begin{array}{l}\text { Fokus Foundation for Youth Culture } \\
\text { and Creativity, Subotica }\end{array}$ & $\begin{array}{c}\text { The Kapmor, } \\
\text { in Hungarian, Serbian and Croatian } \\
\text { languages }\end{array}$ & \\
\hline
\end{tabular}

\subsubsection{Representation of the interests of users of minority languages}

304. As already stated in the Section 4.4.2. of the Report, the provisions of the Law on Broadcasting prescribe the undertakings of public radio broadcasting agencies in respect of interests of minority groups, too - users of minority languages. Pursuant to Article 8 paragraph 1 item 6 of the Law on Broadcasting, the Agency shall supervise the operations of public radio broadcasting agencies and take care that they comply with their undertakings in relation to programme standards defined by the provisions of the Law. If the Agency finds, on the occasion of such supervision, that a public radio broadcasting agency violates its undertakings, it may, within the meaning of Article 17 paragraph 2 and Article 87 paragraph 2 of the Law on Broadcasting, order a measure to the public broadcasting agency (dunning or warning) or, as the last instance, discharge the members of the Board of Directors of the public broadcasting agency. In addition to specific legal obligations in respect of programme contents and their operations in general, it is also prescribed by the provisions of Article 87 paragraphs 1 and 2, Article 92 paragraph 3 and Article 94 paragraph 4 of the same Law that RBA shall appoint and discharge the members of the boards of directors of public radio broadcasting agencies and propose to the National Assembly the candidates for the appointment of members of programmes boards of public radio broadcasting services.

305. In the opinion of the authorities of the Republic of Serbia, the above mentioned provisions give guarantees that the interests of users of minority languages shall be also represented in public radiobroadcasting agencies, although at present they do not have their representatives in the boards of directors and the programme boards of public radiobroadcasting agencies.

306. The Law on the National Councils of the National Minorities defines the competences of national councils in the field of information. Article 20 of this Law prescribes that national councils of national minorities give an opinion in the procedure of appointment of the members of the boards of directors, the programme board and managing director of the Radiobroadcasting Agency of Serbia and the Radiobroadcasting Agency of Vojvodina if those institutions broadcast programmes in minority languages; they set up criteria for the appointment of the programme editor in charge in minority languages at an institution of the public agency; they propose to the board of director of the radiobroadcasting institution to appoint the editor in charge of the programme in 
minority language among the candidates who apply and meet the requirements of the advertisements, and they also give an opinion about the candidates for the editor in charge of the programme in minority languages at the radiobroadcasting institution where the editor in charge for several programmes in minority languages is appointed.

\subsubsection{Activities for the implementation of box-recommendation of the Committee of Experts concerning Article 11 of the Charter}

307. In the Report on the Implementation of the Charter in the first cycle of reporting, the Committee of Experts issued the following recommendation:

The Committee of Experts encourages the Serbian authorities to ensure that the privatisation of local broadcasters does not negatively affect the offer of programmes in the regional or minority languages.

308. The process of privatization of media has not been completed yet in the Republic of Serbia. Although Law on Broadcasting (Article 96 paragraph 10) prescribes that radio and/or television stations of local and regional communities founded by the assembly of municipality, several assemblies of municipalities and the town assembly have an obligation to be privatized not later than 31 December 2007, the process has been stopped because it was noticed that privatization might jeopardize the survival of programmes in minority languages of the media broadcasting it. Bearing in mind the fact that local and regional radio and TV stations are exactly the greatest chances for the members of national minorities to accomplish their right to information in their own mother tongue, the Government of the Republic of Serbia adopted a conclusion on 27 December 2007, which adopted the Information on the necessity to terminate the privatization process of radio and/or television stations and other electronic media broadcasting programmes in minority language. After this the Privatization Agency adjourned the privatization process of these media. The continuation of operations of local and regional media founded by the municipality/town was also strengthened after the period fixed for their privatization in Article 20 item 34 of the Law on Local Self-Government (adopted on 29 December 2007), which prescribes that the municipality may, through its bodies, in accordance with the Constitution and law, establish television and radio stations for the purpose of reporting in minority language officially used in the municipality, as well as for reporting in minority language if it is not officially used if such reporting presents the achieved level of minority rights. According to the data of journalistic associations, slightly more than one third of media has been privatized, while the privatization of press has been completely finished. According to the data of the Privatization Agency, 53 electronic media and press media were privatized in the Republic of Serbia in the last six years. The new media owners are obliged to comply with the Rules on the Method of Privatization of radio and/or television stations of local and regional communities, which oblige them to operate continually. The Rules prescribe that broadcaster, whose programmes have contents in minority languages, must 
continue to operate according to this programme concept. Article 68 of the Law on Broadcasting makes all electronic media obliged to comply with general programme standards when broadcasting programmes. The Republic Radiobroadcasting Agency shall perform the control of programme contents of broadcaster, as already stressed in the above paragraphs on the implementation of Article 11 of the Charter. 
4.5.

\section{Article 12 \\ Cultural Activities and Facilities Selected paragraphs and sub-paragraphs}

1. With regard to cultural activities and facilities - especially libraries, video libraries, cultural centres, museums, archives, academies, theatres and cinemas, as well as literary work and film production, vernacular forms of cultural expression, festivals and the culture industries, including inter alia the use of new technologies - the Parties undertake, within the territory in which such languages are used and to the extent that the public authorities are competent, have power or play a role in this field:

a) to encourage types of expression and initiative specific to regional or minority languages and foster the different means of access to works produced in these languages;

b) to foster the different means of access in other languages to works produced in regional or minority languages by aiding and developing translation, dubbing, postsynchronisation and subtitling activities;

c) to foster access in regional or minority languages to works produced in other languages by aiding and developing translation, dubbing, post-synchronisation and subtitling activities;

f) to encourage direct participation by representatives of the users of a given regional or minority language in providing facilities and planning cultural activities;

2. In respect of territories other than those in which the regional or minority languages are traditionally used, the Parties undertake, if the number of users of a regional or minority language justifies it, to allow, encourage and/or provide appropriate cultural activities and facilities in accordance with the preceding paragraph.

\subsubsection{Encouragement of expression and access to works in minority languages}

309. In this three year period the State also continued to encourage expression and access to works in minority languages. Examples of such efforts are contained in the following paragraphs of this Report.

310. The Ministry of Culture, within its competences, undertakes certain actions striving to enable, encourage and facilitate various forms of expression in minority languages. In view of the fact that minority languages are an integral part of the cultural identity and the grounds to preserve, crate and present cultural values, the Ministry of Culture supports projects related to this area, both financially and/or in logistics. Although co-financing of projects/programmes was established as regular annual activity in 2002, since 2007 the Ministry of Culture has been issuing special tenders to co-finance projects/programmes of national 
minorities. This tender does not only relate to co-financing of cultural projects of minority communities, but it also relates to the area of multi-cultural activities. Since 2008, this tender has also been expanding to financing of magazines in the field of culture, which is presented in minority languages and in the field of publishing in minority languages. The national councils of national minorities are active participants in the procedure of adoption of final decisions on co-financing in each tender. The applications received at the tender are examined and relevant decisions are adopted by an independent commission consisting of experts in relevant fields. The criteria of distribution of funds intended for the culture of national minorities are, inter alia, the following: the importance of the project for the promotion of cultural and linguistic identity, art and culture, promotion and development of multilingual character of the community, contribution to the intercultural dialogue, realistic possibilities of implementation and the quality of the project as the most important criterion. Although care is taken that all national minorities are represented in the selection of the project the funds are to be granted to, the quality of the project is the major criterion of selection. After having noticed that certain minority communities receive less financial support, due to the lack of good quality projects, at the end of 2007 and at the beginning of 2008 the Ministry of Culture performed the training of the members of the national minorities on how to apply to the tenders to be issued by the Ministry, which was carried out under the support of the national councils of national minorities. In order to provide successful training of the members of the national minorities on how to apply to the tenders, as well as to provide successful cooperation with national communities in general, the Ministry printed a guide in compiled form, which explains in details all important elements of the tender procedures. In addition to the measures of affirmative actions, which are applied in relation to the Roma national minority, concrete steps related to the Albanian national minority in the South of Serbia. Since it has been noticed that the national minority concerned had not taken part in the tenders issued by the Ministry of Culture in previous years, through the Co-ordinating Body of the Government of the Republic of Serbia for the Municipalities of Preševo, Bujanovac and Medveđa, information on all essential elements of the tender procedures were forwarded to them, resulting in the first applications to tenders from this region.

311. The adoption of the Law on Establishment of Certain Competences of the Autonomous Province of Vojvodina (2002), major part of competences of the Ministry of Culture, related to the programmes of the national minorities living in this territory, was transferred to the provincial authorities. Although Vojvodina gained the right to develop its own cultural policy and cultural strategies on the grounds of this Law, the obligations of the Ministry of Culture have not eliminated but only decreased in this territory.

312. The Provincial Secretariat of Culture of AP of Vojvodina, in addition to subsidies to the institutions of culture established by the Autonomous Province of Vojvodina also co-finances, on tender basis, the programmes accomplishing the 
needs and interests of national minorities in the field of culture and minority languages they represent.

313. Municipalities, as the basic territorial units of self-government, organize jobs concerning the protection of cultural goods of importance for the municipality, encourage the development of cultural and art works, provide funds to finance and co-finance the programmes and projects in the field of culture of importance for the municipality and create the conditions for the activities of the cultural institutions they are the founders of.

314. The following paragraphs of this Report contain the data on the encouragement of forms of expression and access to works produced in minority languages.

\subsubsection{Libraries}

315. The existence of libraries with book stocks in minority languages available to the members of national minorities are important for fostering of language and culture in general. Public libraries are mainly active in the Republic of Serbia, although it is also possible to establish private libraries in accordance with the Law. According to Article 2 paragraph 2 of the Law on Libraries, library activities include: collection, processing, keeping and use of books, magazines and newspapers, scripts, music works, copies of art paintings and drawings, maps and plans of settlements, phonodocuments, reprographic matter, posters, advertising matter, video and film records and other works that are copied by printing or in other ways, as well as manuscripts and documents in electronic format, as well as collection, processing and rendering of information and data related to the library stock. According to Article 10 item 2 of the Law on Libraries, general interest in the field of library activities is, inter alia, to produce current, retrospective and other bibliography of the Serbian nation and national minorities living in the Republic of Serbia. According to the provision of Article 20 paragraph 1 item 18 of the Law on Local Self-Government, the funds for the activities of the libraries funded by the municipality are provided from the municipal budget. The number of books in minority languages and the availability of libraries to the users of minority languages was also contained in the First Periodical Report on the Implementation of the Charter. For the requirements of this Report, the libraries were interviewed concerning the number of books in minority languages. The table below contains the data on the number of books in minority languages at the libraries that replied to the interviews.

\begin{tabular}{|l|l|r|}
\hline Minority Languages & \multicolumn{1}{|c|}{ Library } & \multicolumn{1}{|c|}{ Number of Books } \\
\hline \multirow{3}{*}{ Albanian } & The 14. novembar, Bujanovac & 15,000 \\
& The Petar Petrović Njegoš, Medveđa & 2,943 \\
& The Mehmet Jusufi, Preševo & 7,775 \\
\hline \multirow{3}{*}{ Bosniak } & The Dositej Obradović, Novi Pazar & 1,814 \\
& The Vuk Karadžić, Prijepolje & 700 \\
& The De Ejup Mišović, Tutin & 249 \\
\hline & The Public Library, Babušnica & 5,700 \\
& The Hristo Botev, Bosilegrad & 6,378 \\
\hline
\end{tabular}




\begin{tabular}{|c|c|c|}
\hline Bulgarian & $\begin{array}{l}\text { The Detko Petrov, Dimitrovgrad } \\
\text { The Dositej Obradović, Negotin } \\
\text { The Stevan Sremac, Niš } \\
\text { The Public Library, Pirot }\end{array}$ & $\begin{array}{r}12,000 \\
40 \\
57 \\
80\end{array}$ \\
\hline \multirow{24}{*}{ Hungarian } & The Sarvaš Gabor, Ada & 27,511 \\
\hline & The Public Library, Apatin & 10,334 \\
\hline & The Vuk Karadžić, Bač & 302 \\
\hline & The Veljko Petrović, Bačka Palanka & 1,016 \\
\hline & The Public Library, Bačka Topola & 81,027 \\
\hline & The Public Library, Bečej & 39,788 \\
\hline & The Danilo Kiš, Vrbas & 7,783 \\
\hline & The Town Library, Vršac & 5,538 \\
\hline & The Branko Radičević, Žitište & 9,847 \\
\hline & The Town Library, Zrenjanin & 19,785 \\
\hline & The Đorđe Natošević, Inđija & 1,037 \\
\hline & The Jožef Atila, Kanjiža & 42,032 \\
\hline & The Jovan Popović, Kikinda & 32,969 \\
\hline & The Municipal Library, Kovačica & 3,228 \\
\hline & The Vuk Karadžić, Kovin & 6,461 \\
\hline & The Public Library, Kula & 5,046 \\
\hline & The Matica Srpska Library, Novi Sad & 39,482 \\
\hline & The Town Library, Novi Sad & 19,021 \\
\hline & The Town Library, Pančevo & 7,689 \\
\hline & The Public Library, Plandište & 41 \\
\hline & The Town Library, Senta & 41,642 \\
\hline & The Karlo Bjelicki, Sombor & 63,882 \\
\hline & The Gligorije Vozarević, Sremska Mitrovica & 18 \\
\hline & The Simraj Karolj, Temerin & 15,048 \\
\hline \multirow{3}{*}{ Romani } & The Public Library, Bela Crkva & 20 \\
\hline & The Stevan Sremac, Niš & 5 \\
\hline & The Town Library, Novi Sad & 542 \\
\hline \multirow{8}{*}{ Romanian } & The Town Library, Vršac & 3,085 \\
\hline & The Branko Radičević, Žitište & 4,924 \\
\hline & The Town Library, Zrenjanin & 90 \\
\hline & The Vuk Karadžić, Kovin & 2,719 \\
\hline & The Matica Srpska Library, Novi Sad & 9,416 \\
\hline & The Town Library, Novi Sad & 3,424 \\
\hline & The Town Library, Pančevo & 7,689 \\
\hline & The Public Library, Plandište & 114 \\
\hline \multirow{7}{*}{ Ruthenian } & The Public Library, Bačka Topola & 256 \\
\hline & The Danilo Kiš, Vrbas & 2,900 \\
\hline & The Veljko Petrović, Žabalj & 550 \\
\hline & The Matica Srpska Library, Novi Sad & 3,292 \\
\hline & The Town Library, Novi Sad & 528 \\
\hline & The Gligorije Vozarević, Sremska Mitrovica & 74 \\
\hline & The Simeon Piščević, Šid & 255 \\
\hline \multirow{10}{*}{ Slovak } & The Štefan Homola, Bački Petrovac & 1,356 \\
\hline & The Veljko Petrović, Bačka Palanka & 4,747 \\
\hline & The Public Library, Bačka Topola & 467 \\
\hline & The Danilo Kǐs, Vrbas & 49 \\
\hline & The Town Library, Zrenjanin & 41 \\
\hline & The Municipal Library, Kovačica & 10,898 \\
\hline & The Matica Srpska Library, Novi Sad & 6,395 \\
\hline & The Town Library, Novi Sad & 7,892 \\
\hline & The Town Library, Pančevo & 274 \\
\hline & The Gligorije Vozarević, Sremska Mitrovica & 7 \\
\hline
\end{tabular}




\begin{tabular}{|l|l|r|}
\hline & The Dositej Obradović, Stara Pazova & 6,880 \\
& The Simeon Piščević, Šid & 38 \\
\hline
\end{tabular}

\subsubsection{Cultural clubs, cultural centres and cultural institutions}

316. Cultural clubs and cultural centres are the basic cultural institutions in the units of local self-government, which subsidize their activities. They are most frequently those organizing the most important cultural manifestations and the institutions promoting culture and linguistic diversity and minority languages, as well as the access to works produced in the languages concerned in multi-national communities.

317. In 2003 the Assembly of AP of Vojvodina founded the Institute of Culture of Vojvodina. The aim of foundation of this Institute is to foster and promote modern cultural strategies, investigations of possibilities to apply and develop new cultural models in Vojvodina, networking of the existing cultural institutions and affirmation of multiculturalism. The programme concept of the Institute includes scientific, expert, development and applied researches, and to stimulates modern artistic production in Vojvodina through the implementation of projects covering management in culture, cultural production, cultural tourism, organization of cultural-artistic manifestations, presentation, informativedocumentary activities, new media, professional training and education in culture and art. The activities of the Institute are aimed at fostering, development and organization of: culture and language of nation, national and ethnic communities in AP of Vojvodina; painting and music and theatre activities in AP of Vojvodina (drama, opera, ballet, ballet and other similar activities); galleries; amateurism in AP of Vojvodina according to the plan and programme of the Association of Amateurs of Vojvodina; multiculturalism and interculturalism in the territory of Vojvodina; establishment of links and co-operation between cultural institutions, enabling individuals in AP of Vojvodina to make contacts with international institutions and organizations. The Institute actively participates in the implementation of the policy of the provincial authority in charge of culture. Department of development and Research of the Institute of Culture of Vojvodina also implemented the project Language and Identity, which affirmed multiculturalism and promoted modern artistic expression and culture, included a series of activities related to visits of modern writers, presentation of scientific works, organization of lectures, promotions of books, exhibitions, etc. The following topics have been discussed so far: literature in Romanian and Hungarian languages, and promotion of literature in Romani language. The Coordinating Body of the Association for Languages, Literature and Culture is also active, among other authorities, within the Institute of Culture of Vojvodina, which includes 23 units (associations, sections, clubs) organizing various activities in Serbian language and in the following minority languages: Bulgarian, Macedonian, Hungarian, German, Romani, Romanian, Ruthenian, Slovak, Ukrainian, Croatian and Czech. 
318. In order to foster, promote and develop culture and minority languages, the Assembly of AP of Vojvodina and the national councils of the Hungarian, Romanian, Ruthenian, Slovak, and Croatian national minorities in 2008 established the institutes of culture, as professional cultural institutions of the minority communities concerned. The objectives the institutions had been established for, will be accomplished by: development-research and analyses of cultural infrastructure of the speakers of languages concerned in order to achieve their development; informative-documentary activities, permanent and systematic activities to improve the quality of cultural and artistic manifestations, as well as by professional training and education in culture. The decisions on establishment of those institutions prescribe that their activities are: publishing of books, brochures, music books and publications, magazines and similar periodical issues and audio records; research and experiments in social and humanitarian sciences; market and public opinion researches; consulting and management; library activities; archive activities; museums, galleries and collections; protection of cultural goods, natural resources and other monuments. The institutes of culture of national minorities established in this form in the Republic of Serbia are unique and they do not exist in any other country in the surroundings. Through the implementation of projects of scientific, development and applied researches in the field of culture, art and science, as well as through the organization of cultural and artistic programmes, these institutions have already significantly contributed to fostering and preservation of national identity, minority languages and cultures of various national minorities living in Vojvodina, also contributing at the same time to the development of multiculturalism and multilingual character of Vojvodina, and to the accessibility of such cultures and minority languages to all citizens. The funds for the activities and programmes of the institutions of culture are provided from the budget $(90 \%)$, and from the income of their own operations and funds, foundations, donations, contributions, etc.

319. The Table below contains the data about the funds provided from the budget of AP of Vojvodina for the activities of the institutions of culture of national minorities.

\begin{tabular}{|l|c|c|}
\hline \multicolumn{1}{|c|}{ Name } & 2008 & 2009 \\
\hline $\begin{array}{l}\text { The Institute of Culture of Hungarians of Vojvodina - } \\
\text { Vajdasági Magyar Művelődési Intézet, Senta }\end{array}$ & $12,000,000.00$ & $8,300,000.00$ \\
\hline $\begin{array}{l}\text { The Institute of Culture of Romanians of Vojvodina - } \\
\text { Institutul de Cultuã al Românilor din Vojvodina, Zrenjanin }\end{array}$ & $8,000,000.00$ & $4,000,000.00$ \\
\hline $\begin{array}{l}\text { The Institute of Culture of Ruthenians of Vojvodina - Завод } \\
\text { за културу войводянских Pуснацох, Novi Sad }\end{array}$ & $6,500,000.00$ & $3,250,000.00$ \\
\hline $\begin{array}{l}\text { The Institute of Culture of Slovaks of Vojvodina - Ústav pre } \\
\text { kultúru vojvodinských Slovákov, Novi Sad }\end{array}$ & $10,000,000.00$ & $5,000,000.00$ \\
\hline $\begin{array}{l}\text { The Institute of Culture of Croatians of Vojvodina - Zavod } \\
\text { za kulturu vojvođanskih Hrvata, Subotica }\end{array}$ & $5,500,000.00$ & $4,150,000.00$ \\
\hline
\end{tabular}

\subsubsection{Protection of cultural goods (cultural monuments, museums and archives)}


320. In the Republic of Serbia there is no difference in protection of cultural goods on origin basis. The laws governing this area, including also the activities of the institutions for protection of cultural monuments, museums, galleries, archives and libraries, as well as the standards of protection of cultural heritage impose that cultural goods are treated and protected equally regardless of the time of their making and cultural origin. On the other hand, bearing in mind that cultural heritage and its complexity make an important part of modern identity of local communities fostering it and that it plays an important role in fostering of cultural diversities and development of intercultural dialogue, the Ministry of Culture paid attention to this aspect of cultural heritage, fully respecting the principles mentioned in the UNESCO Convention on Protection of Diversities of Cultural Expressions in the previous period. In this sense, the most important project is the development project of the Vekovi Bača, which includes protection and maintenance of rich multicultural heritage in the territory of Bač and the material heritage - the Franciscan Convent, the Bodani Orthodox Monastery, the medieval tower, the remains of the Turkish bath, etc. and also the maintenance of various traditions related to well preserved and live non-material heritage being fostered by about 20 different ethnic groups. Because of its historical and cultural values of the heritage and its multiculturalism, in 2008 this project was selected as one of the three projects of the Republic of Serbia to participate in the Ljubljana Process, which presents a common initiative of the Council of Europe and the European Commission for Protection of Cultural and Natural Heritage in the South-East Europe. The aim of the project Vekovi Bača is a social-economic development of the municipality based on wise utilization of rich heritage, implying preservation of material and non-material culture of diversities with a particular stress on the development of intercultural dialogue.

321. In the previous three years the funds in the total amount of 7,080,000.00 dinars were provided from the provincial budget for the project Vekovi Bača in the field of protection of cultural heritage including the manifestation of the European Heritage Days.

322. Under the support of the Ministry of Culture the following projects contributing to the preservation and protection of cultural heritage of national minorities and minority languages have also been implemented:

- The Ethnographic Museum in Belgrade - the Đelem, đelem programme promoting the culture of the Roma in Serbia and the promotion of the book Islamski spomenici $i$ islamska zajednica Prijepolja arranged by the National Museum in Prijepolje;

- The Historic Archive of Bela Crkva - the project Predstava između Nere $i$ Karaša, which through an exhibition of the archive documents and theatrical performance, presented the history of Bela Crkva stressing its multiculturalism; 
- The Historic Archive of Novi Pazar - the project of publishing of the Izbice od davnina monography documenting and reflecting the multicultural community of Novi Pazar and the exhibition of archive documents and photographs under the subject Novi Pazar, Sjenica and Tutin kroz vreme, thus contributing to building a dialogue between cultures and ethnic communities living in this environment;

- The Historic Archive of the Town of Novi Sad - the project Međuetnički dijalozi na teritoriji Vojvodine, which included the research of the archive stock and field works..

\subsubsection{Theatres}

323. Theatre art in minority languages is of a particular importance for fostering of minority languages and promotion and development of cultures they represent, which is financially supported by the state.

324. Theatre performances in Albanian language performed by two amateur theatres, one with the Jehona Cultural-Artistic Society from Veliki Trnovac, financed by the local self-government and the other, the Town Amateur Theatre from Preševo.

325. On tender basis for the projects/programmes the quality of which contributes to the development and the presentation of art and culture, in 2007, the Ministry of Culture supported the Jehona Cultural-Artistic Society drama programme with $80,000.00$ dinars and the Dani albanske komedije manifestation with 200,000.00 dinars.

326. Performances in Bosniak language are performed by one professional theatre. In addition to performances in Serbian language, the Regional Theatre in Novi Pazar also has two annual premiers in Bosniak language.

327. On tender basis for co-financing of the projects/programmes the quality of which contributes to the development and the presentation of art and culture of national minorities the Ministry of Culture supported the performance of the following theatre performances in Bosniak language:

\begin{tabular}{|l|l|r|}
\hline \multicolumn{1}{|c|}{ Beneficiary } & \multicolumn{1}{c|}{ Project } & Granted Funds \\
\hline The Regional Theatre, Novi Pazar & $\begin{array}{l}\text { Žute dunje } \text { i limuni }- \text { theatre } \\
\text { performance }\end{array}$ & $240,000.00$ \\
\hline $\begin{array}{l}\text { The Sjenica Amateur Theatre and the } \\
\text { National Council of the Bosniak } \\
\text { National Minority, Novi Pazar }\end{array}$ & Ramiza - theatre performance & $150,000.00$ \\
\hline
\end{tabular}

328. The Hristo Botev theatre from Dimitrovgrad has performances in Bulgarian language. This theatre also has an annual premier in Bulgarian language.

329. On tender basis for co-financing of the projects/programmes the quality of which contributes to the development and the presentation of art and culture of national 
minorities the Ministry of Culture supported the performance of the following theatre performances in Bulgarian language:

\begin{tabular}{|c|l|r|}
\hline \multicolumn{1}{|c|}{ Beneficiary } & \multicolumn{1}{|c|}{ Project } & Granted Funds \\
\hline The Cultural Centre Dimitrovgrad & $\begin{array}{l}\text { Doživljaji Pričalice Brbljiković, theatre } \\
\text { performance }\end{array}$ & $\begin{array}{l}\text { Princeza Fina Žozefina, princ Hrabrić } i \\
\text { još poneko, theatre performance }\end{array}$ \\
\hline
\end{tabular}

330. In the territory of AP of Vojvodina theatre performances in Hungarian language are conducted by 4 professional and 30 amateur theatres.

Professional theatres are:

- The National Theatre - Népszinház in Subotica including the Drama in Hungarian language

- The Theatre of Novi Sad - Ujvídéki színház in Novi Sad

- The Children's Theatre - Gyermekszinház in Subotica also has a group in Hungarian language

- The Doll's Scene of the Tořa Jovanović National Theatre in Zrenjanin, also has performances in Hungarian language.

331. The entire activities of the National Theatre - Népszinház are financed from the budget of AP of Vojvodina. In 2007, 30,988,043.00 dinars were granted from the budget of AP of Vojvodina for the activities of the Drama in Hungarian language of this theatre. In 2008, 34,636,028.00 dinars were granted and 32,991,350 dinars were granted in 2009.

332. The Provincial Secretariat of Culture of AP of Vojvodina also co-financed from the budget the activities of other theatres performing in Hungarian language. The Table below contains the examples of such financing.

\begin{tabular}{|l|l|r|}
\hline \multicolumn{1}{|c|}{ Theatre } & \multicolumn{1}{c|}{ Programme } & Granted Funds \\
\hline The Salašarsko Theatre, Novi Sad & Performances in Hungarian language & $3,275,000.00$ \\
\hline $\begin{array}{l}\text { The Theatre of Novi Sad - Ujvídéki } \\
\text { színház, Novi Sad }\end{array}$ & $\begin{array}{l}\text { Co-financing of visiting performances } \\
\text { in different places of Vojvodina }\end{array}$ & $660,000.00$ \\
\hline $\begin{array}{l}\text { The Kostolanji Deže Theatre - } \\
\text { Kosztolányi Dezső Színház, Subotica }\end{array}$ & $\begin{array}{l}\text { Tramvaj Dezire, project } \\
\text { Co-financing of visiting performances } \\
\text { in different places of Vojvodina }\end{array}$ & $1,400,000.00$ \\
\hline
\end{tabular}

333. On tender basis for co-financing of the projects/programmes the quality of which contributes to the development and the presentation of art and culture of national minorities the Ministry of Culture supported theatre festivals and performances in Hungarian language.

\begin{tabular}{|l|l|r|}
\hline \multicolumn{1}{|c|}{ Beneficiary } & \multicolumn{1}{c|}{ Project } & Granted Funds \\
\hline The Theatre of Novi Sad, Novi Sad & Mizantrop, theatre performance & $100,000.00$ \\
\hline The Most Fund, Subotica & Isus Hrist Superstar, theatre & $100,000.00$ \\
\hline
\end{tabular}




\begin{tabular}{|l|l|r|}
\hline & performance & \\
\hline $\begin{array}{l}\text { The Cultural Association of } \\
\text { Hungarians of Vojvodina, Subotica }\end{array}$ & $\begin{array}{l}13^{\text {th }} \text { Festival of Hungarian Amateur } \\
\text { Theatres of Vojvodina }\end{array}$ & $60,000.00$ \\
\hline
\end{tabular}

334. The Table below contains the data about the funds granted for theatre performances and theatre manifestations in Hungarian language according to the individual applications submitted to the tenders issued by the Provincial Secretariat of Culture of AP of Vojvodina.

\begin{tabular}{|c|c|c|}
\hline Beneficiary & Purpose & Granted Funds \\
\hline $\begin{array}{l}\text { The Mara Amateur Theatre, Bačka } \\
\text { Topola }\end{array}$ & $\begin{array}{l}\text { Preparation of two theatre } \\
\text { performances }\end{array}$ & $35,000.00$ \\
\hline $\begin{array}{l}\text { The Petefi Šandor Cultural } \\
\text { Association, Bezdan }\end{array}$ & $\begin{array}{l}\text { Theatre performance in Hungarian } \\
\text { language }\end{array}$ & $25,000.00$ \\
\hline $\begin{array}{l}\text { The Kucko Children's Club, } \\
\text { Doroslovo }\end{array}$ & $\begin{array}{l}2^{\text {nd }} \text { Drama Festival of Pre-School } \\
\text { Children of the West-Banat District }\end{array}$ & $60,000.00$ \\
\hline $\begin{array}{l}\text { The Petefi Šandor Cultural-Artistic } \\
\text { Association, Mužlja }\end{array}$ & $\begin{array}{l}14^{\text {th }} \text { Festival of Hungarian Amateur } \\
\text { Theatres of Vojvodina }\end{array}$ & $50,000.00$ \\
\hline $\begin{array}{l}\text { The Madach Amateur Theatre, } \\
\text { Zrenjanin }\end{array}$ & Mi, muzičke duše, Operetta Scene & $45,000.00$ \\
\hline $\begin{array}{l}\text { Association of Hungarian Pre-School } \\
\text { Teachers and Teachers of Vojvodina, } \\
\text { Mali Iđoš }\end{array}$ & Festival of Amateur Doll's Theatre & $15,000.00$ \\
\hline Parents' Forum, Novi Sad & $\begin{array}{l}\text { Establishment of doll's theatre for } \\
\text { children }\end{array}$ & $50,000.00$ \\
\hline The Theatre of Novi Sad, Novi Sad & $\begin{array}{l}\text { Pupil's Scene theatre performance: } \\
\text { Mrožek, Udovice } \\
\text { Pupils Scene: Shakespeare, Much Ado } \\
\text { about Nothing }\end{array}$ & $\begin{array}{l}45,000.00 \\
40,000.00\end{array}$ \\
\hline $\begin{array}{l}\text { Association of Hungarian Teachers of } \\
\text { Vojvodina, Novi Sad }\end{array}$ & Children's Theatre Festival & $30,000.00$ \\
\hline $\begin{array}{l}\text { Turzo Lajoš, Cultural-Educational } \\
\text { Centre, Senta }\end{array}$ & Activity of Senta Theatre & $125,000.00$ \\
\hline$T s T$, Association of Citizens, Senta & Performance for children & $30,000.00$ \\
\hline The Berta Ferenc, Theatre, Sombor & Susreti, performance & $40,000.00$ \\
\hline $\begin{array}{l}\text { The Kostolanji Deže Theatre - } \\
\text { Kosztolányi Dezső Színház, Subotica }\end{array}$ & $\begin{array}{l}\text { Theatre performances: Pilinski Janoš, } \\
\text { Urbi et orbi, Mrožek, Tango and Brad } \\
\text { Fraser, Prava priroda ljubavi ili } \\
\text { neidentifikovani ljudski ostaci }\end{array}$ & $250,000.00$ \\
\hline $\begin{array}{l}\text { The Cultural Alliance of Vojvodina's } \\
\text { Hungarians, Subotica }\end{array}$ & $\begin{array}{l}12^{\text {th }} \text { and } 13^{\text {th }} \text { Festival of Hungarian } \\
\text { Amateur Theatres of Vojvodina }\end{array}$ & $130,000.00$ \\
\hline The National Theatre, Subotica & $\begin{array}{l}\text { Days of Hungarian Acting in } \\
\text { Vojvodina }\end{array}$ & $80,000.00$ \\
\hline $\begin{array}{l}\text { The Petefi Šandor Cultural } \\
\text { Association, Telečka }\end{array}$ & $\begin{array}{l}13^{\text {th }} \text { Festival of Hungarian Amateur } \\
\text { Theatres of Vojvodina }\end{array}$ & $150,000.00$ \\
\hline The Orfeus Amateur Theatre, Čoka & Još živimo, theatre days & $30,000.00$ \\
\hline $\begin{array}{l}\text { Association of Hungarian Reciters of } \\
\text { Vojvodina, Feketić }\end{array}$ & Biti Mađar, visiting performance & $25,000.00$ \\
\hline $\begin{array}{l}\text { Association of Hungarian Drama } \\
\text { Pedagogues in Vojvodina, Feketić }\end{array}$ & $\begin{array}{l}\text { Workshops of Children's Theatre } \\
\text { Production }\end{array}$ & $80,000.00$ \\
\hline
\end{tabular}


335. Theatre performances in Romani language in the territory of AP of Vojvodina are performed by one professional and three amateur theatres.

336. The Romani Theatre Suno e Rromengo in Novi Karlovci, which was established in 2007 as a professional theatre, has performances in Romani language. The theatre has one or two premier performances and ten replay performances annually. In addition to performances in various places of Vojvodina and Serbia, it also has performances in the neighbouring and other European countries. The Provincial Secretariat of Culture of AP of Vojvodina subsidized the activities of Suno e Rromengo theatre. In 2007, the subsidy amounted to 800,000.00 dinars, in 2008 it amounted to 2,450,000.00 dinars and in 2009 it amounted to 1,200,000.00 dinars. The profesionalisation of activities and the training of actors and actresses of this theatre were financed by the Provincial Secretariat of Culture of AP of Vojvodina with 625,000,000.00 dinars in 2008.

337. On tender basis for co-financing of the projects/programmes the quality of which contributes to the development and the presentation of art and culture of national minorities the Ministry of Culture supported the projects related to theatre activities and theatre performances in Romani language.

\begin{tabular}{|l|l|c|}
\hline \multicolumn{1}{|c|}{ Beneficiary } & \multicolumn{1}{|c|}{ Project } & Granted Funds \\
\hline $\begin{array}{l}\text { Kulturmobil, Association of Citizens, } \\
\text { Belgrade }\end{array}$ & Čarninin poj, performance & $350,000.00$ \\
\hline $\begin{array}{l}\text { Bare jaga, Association of Culture and } \\
\begin{array}{l}\text { Education of Roma, Mačvanska } \\
\text { Mitrovica }\end{array}\end{array}$ & $\begin{array}{l}\text { Educational workshop of the youth } \\
\text { theatre }\end{array}$ & $120,000.00$ \\
\hline $\begin{array}{l}\text { Multimedia Centre of Serbian Roma, } \\
\text { Trstenik }\end{array}$ & $\begin{array}{l}\text { Establishment of the ROM-drom } \\
\text { Theatre }\end{array}$ & $300,000.00$ \\
\hline
\end{tabular}

338. In 2008, the Ministry of Human and Minority Rights granted 295,000.00 dinars for the organization and the implementation of the musical Molitva za jug.

339. According to the individual applications submitted to the tenders, the Provincial Secretariat of Culture of AP of Vojvodina granted 60,000.00 dinars to the Beočin, Association of Roma from Beočin for the performance Zvono in Romani language.

340. In the territory of AP of Vojvodina theatre performances in Romanian language are conducted by one professional and 12 amateur theatres. The Sterija National Theatre in Vršac, which is a professional theatre, has a department in Romanian language successfully performing plays in the country and abroad. It has two premier performances and 20 replay performances annually. The Provincial Secretariat of Culture of AP of Vojvodina subsidized the programme of this department in Romanian language. In 2007 subsidy amounted to 2,500,000.00 dinars, in 2008 it amounted to 2,650,000.00 dinars and in 2009, it amounted to $1,200,000.00$ dinars. 
341. On tender basis for co-financing of the projects/programmes the quality of which contributes to the development and the presentation of art and culture of national minorities the Ministry of Culture supported the performance of the following theatre manifestations and theatre performances in Romanian language.

\begin{tabular}{|l|l|r|}
\hline \multicolumn{1}{|c|}{ Beneficiary } & \multicolumn{1}{c|}{ Project } & Granted Funds \\
\hline $\begin{array}{l}\text { Romanian Community in Serbia - the } \\
\text { Alibunar Branch, Alibunar }\end{array}$ & Theatre performance & $60,000.00$ \\
\hline $\begin{array}{l}\text { Association of Romanian Amateur } \\
\begin{array}{l}\text { Theatres in AP of Vojvodina, } \\
\text { Alibunar }\end{array}\end{array}$ & $\begin{array}{l}35^{\text {th }} \text { and } 36^{\text {th }} \text { Festival of Theatres of } \\
\text { Romanians in Vojvodina }\end{array}$ & $200,000.00$ \\
\hline
\end{tabular}

342. The Table below contains the data about the funds granted for theatre manifestations and theatre performances in Romanian language according to the individual applications submitted to the tenders issued by the Provincial Secretariat of Culture of AP of Vojvodina.

\begin{tabular}{|l|l|r|}
\hline \multicolumn{1}{|c|}{ Beneficiary } & \multicolumn{1}{c|}{ Purpose } & Granted Funds \\
\hline $\begin{array}{l}\text { Association of Romanian Amateur } \\
\text { Theatres in AP of Vojvodina, } \\
\text { Alibunar }\end{array}$ & $\begin{array}{l}35^{\text {th }}, 36^{\text {th }} \text { and } 37^{\text {th }} \text { Festival of Theatres } \\
\text { of Romanians }\end{array}$ & $600,000.00$ \\
\hline $\begin{array}{l}\text { Romanian Community in Serbia, } \\
\text { Vršac }\end{array}$ & $\begin{array}{l}\text { Sta se, dođavola, dešava sa ovim } \\
\text { vozom, theatre performance }\end{array}$ & $25,000.00$ \\
\hline
\end{tabular}

343. In the territory of AP of Vojvodina theatre performances in Ruthenian language are conducted by one professional and 15 amateur theatres. The Đađa, Ruthenian National Theatre in Ruski Krstur has two premier performances and 20 replay performances, subsidized by the Provincial Secretariat of Culture of AP of Vojvodina. In 2007 subsidy amounted to 2,500,000.00 dinars, in 2008 it amounted to 2,650,000.00 dinars and in 2009, it amounted to 1,200,000.00 dinars.

344. On tender basis for co-financing of the projects/programmes the quality of which contributes to the development and the presentation of art and culture of national minorities the Ministry of Culture financially supported the event of the Petar Riznič Đađa Drama Memorial in Ruski Krstur with 250,000.00 dinars.

345. The Table below contains the data about the funds granted for theatre manifestations and theatre performances in Ruthenian language according to the individual applications submitted to the tenders issued by the Provincial Secretariat of Culture of AP of Vojvodina.

\begin{tabular}{|l|l|r|}
\hline \multicolumn{1}{|c|}{ Beneficiary } & \multicolumn{1}{|c|}{ Purpose } & Granted Funds \\
\hline The Karpati, Cultural Centre, Vrbas & Trilingual drama performance & $15,000.00$ \\
\hline $\begin{array}{l}\text { The Žetva, Cultural-Artistic } \\
\text { Association, Kucura }\end{array}$ & $\begin{array}{l}\text { Prva ljubav, drama performance and } \\
\text { Bunda od medveda, youth theatre } \\
\text { perfromance }\end{array}$ & $50,000.00$ \\
\hline $\begin{array}{l}\text { The Matica Srpska Town Board, Novi } \\
\text { Sad }\end{array}$ & $5^{\text {th }}$ Monodrama Festival & $50,000.00$ \\
\hline Association of Ruthenians of Novi Sad & $6^{\text {th }}$ and $7^{\text {th }}$ Monodrama Festival and $2^{\text {nd }}$ & $70,000.00$ \\
\hline
\end{tabular}




\begin{tabular}{|l|l|r|}
\hline The Matka, Novi Sad & Duodrama Festival & $400,000.00$ \\
\hline Cultural Centre, Ruski Krstur & $\begin{array}{l}39^{\text {th }} \text { and } 40^{\text {th }} \text { Petar Riznič Đađa Drama } \\
\text { Memorial }\end{array}$ & $\begin{array}{l}\text { Theatre performances Šeregij, Gladni } \\
\text { and Đorđe Milosavljavić, Instant }\end{array}$ \\
\hline
\end{tabular}

346. In the territory of AP of Vojvodina theatre performances in Slovak language are conducted by one professional and 20 amateur theatres. Nowadays, the successful and long tradition of theatre performances dating back to 1866, when the first theatre performance was played in Bački Petrovac, is represented by the Slovak Theatre of Vojvodina. For two premier performances and 20 replay performances in 2007 the Provincial Secretariat of Culture of AP of Vojvodina subsidized this theatre with 2,500,000.00 dinars. In 2008 subsidy amounted to 2,650,000.00 dinars and in 2009, it amounted to 1,200,000.00 dinars. In addition in the course of 2007 and 2008 the funds in the amount of 4,100,000.00 dinars were granted to this theatre from the budget of AP of Vojvodina for the project of acting studies in Slovak language.

347. The Hleba i igara Art Centre, amateur theatre from Stara Pazova was granted the amount of 4,300,000.00 dinars from the budget of AP of Vojvodina for the activities of the centre (premiers and replays) as well as for the visits to Cairo and Tehran (2008) and Budapest (2009).

348. The Table below contains the data about the funds granted for theatre manifestations and theatre performances in Slovak language according to the individual applications submitted to the tenders issued by the Provincial Secretariat of Culture of AP of Vojvodina.

\begin{tabular}{|l|l|r|}
\hline \multicolumn{1}{|c|}{ Beneficiary } & \multicolumn{1}{|c|}{ Purpose } & Granted Funds \\
\hline 3. Oktobar, Cultural Club, Kovačica & Theatre performance: A. Čehov, Višnjik & $60,000.00$ \\
\hline $\begin{array}{l}\text { Janko Čeman, Amateur Theatre, } \\
\text { Pivnice }\end{array}$ & DIDA Theatre Festival & $310,000.00$ \\
\hline $\begin{array}{l}\text { Jan Kolar, Cultural-Artistic } \\
\text { Association, Selenča }\end{array}$ & Festival of Slovak Amateur Thatres & $75,000.00$ \\
\hline $\begin{array}{l}\text { Heroj Janko Čmelik, Slovak Cultural- } \\
\text { Artistic Association, Stara Pazova }\end{array}$ & Theatre performance & $40,000.00$ \\
\hline
\end{tabular}

349. In the territory of AP of Vojvodina theatre performances in Croatian language are conducted by 2 amateur theatres.

350. On tender basis for co-financing of the projects/programmes the quality of which contributes to the development and the presentation of art and culture of national minorities, in 2008 the Ministry of Culture financially supported the Ljutovo, Croatian Cultural-Artistic Association from Ljutovo with 80,000.00 dinars for the Festival of Amateur Theatres. 
351. In 2007 the Provincial Secretariat of Culture of AP of Vojvodina co-financed the Stanislav Preprek, Croatian Cultural-Artistic Association from Novi Sad with 100,000.00 dinars for the preparation of the performance Atentatori.

352. The Table below contains the data about the funds granted by the Provincial Secretariat of Culture of AP of Vojvodina for theatre performances in Croatian language.

\begin{tabular}{|l|l|c|}
\hline \multicolumn{1}{|c|}{ Beneficiary } & \multicolumn{1}{|c|}{ Purpose } & Granted Funds \\
\hline $\begin{array}{l}\text { Mostonga, Croatian Cultural-Artistic- } \\
\text { Singing Association, Bač }\end{array}$ & $\begin{array}{l}\text { Iz domovine u domovinu, theatre } \\
\text { performance }\end{array}$ & $25,000.00$ \\
\hline $\begin{array}{l}\text { Lemeš, Croatian-Bunjevac Cultural- } \\
\text { Artistic Association, Svetozar Miletić }\end{array}$ & U gostima, theatre performance & $13,000.00$ \\
\hline $\begin{array}{l}\text { Bunjevačko kolo, Croatian Cultural } \\
\text { Centre, Subotica }\end{array}$ & $\begin{array}{l}\text { Sunce, djever } \text { i Neva Nevičica, theatre } \\
\text { performance for children }\end{array}$ & $40,000.00$ \\
\hline
\end{tabular}

\subsubsection{Publishing (literary works)}

353. The State continues to support financially the publishing of books in minority languages. Since 2008, the tender for co-financing of the projects/programmes the quality of which contributes to the development and the presentation of art and culture of national minorities, which is issued annually by the Ministry of Culture, also relates to publishing activities in minority languages. The Provincial Secretariat of Culture of AP of Vojvodina annually issues a tender for publishing of new books in minority languages and for the translations of books from Serbian language into minority languages or from minority languages into Serbian language. The examples of the support concerned are contained in the following paragraphs.

354. Feniks from Preševo is the only publishing house for books in Albanian language, which published twelve books written by the authors from Preševo and Bujanovac in the previous three years.

355. The Centre of Bosniak Studies from Tutin is the largest publisher of books in Bosniak language. In addition of publishing of twelve text books for Bosniak language with elements of national culture as a subject for primary schools, this publisher also publishes two books in Bosniak language annually. For the project of publishing of the book Pjesme od behara, on the basis of the tender for cofinancing of the projects/programmes the quality of which contributes to the development and the presentation of art and culture of national minorities, the Ministry of Culture granted the amount of 50,000 dinars to the Centre of Bosniak Studies.

356. In 2007 the Agency of Human and Minority Rights granted 200,000.00 dinars for the publishing of the Sandžački Bošnjaci monography. 
357. The Bratstvo Newspaper Publishing Agency from Niš, which was founded by the National Council of the Bulgarian National Minority issues from 3-5 books annually in Bulgarian language. Until 2009 the Bratstvo Newspaper Publishing Agency was financed from the republic budget.

358. On tender basis for co-financing of the projects/programmes the quality of which contributes to the development and the presentation of art and culture of national minorities the Ministry of Culture supported the publishing activities in Bulgarian language.

\begin{tabular}{|l|l|r|}
\hline \multicolumn{1}{|c|}{ Beneficiary } & \multicolumn{1}{c|}{ Project } & Granted Funds \\
\hline $\begin{array}{l}\text { The Detko Petrov, Public Library, } \\
\text { Dimitrovgrad }\end{array}$ & $\begin{array}{l}\text { Publishing of the book: Muzejska } \\
\text { zbirka u Dimitrovgradu }\end{array}$ & $120,000.00$ \\
\hline $\begin{array}{l}\text { The Caribrod, Cultural-Information } \\
\text { Centre }\end{array}$ & $\begin{array}{l}\text { Crkva i manastiri } \text { u caribrodskom } \\
\text { (dimitrovgradskom) kraju }\end{array}$ & $200,000.00$ \\
& Sabrani stripovi Metodi Petrova & $60,000.00$ \\
\hline
\end{tabular}

359. Forum, Publishing Institute - Forum Könyvkiadó Intézet from Novi Sad is the largest publishing company publishing books in Hungarian language. In the middle of 2008, the founding rights of this company were transferred to AP of Vojvodina. The activities of this institute, which annually publishes from 30 to 35 books in Hungarian, as well as the magazines in culture, the Hid and the Üzenet, are entirely financed from the budget of AP of Vojvodina. In 2008, the funds in the amount of 5,639,330.00 dinars were provided for the activities of Forum and in 2009 the founds amounted to $13,078,595.00$ dinars.

360. Magyar Szó (which was founded by the National Council of the Hungarian national Minority) also deals with the publishing of books in Hungarian language as secondary activity. In 2007 it published 7 books, in 2008 it published 5 books and in 2009 it published 3 books.

361. In 2008 the Ministry of Human and Minority Rights allocated 150,000,000.00 dinars for the publication under the title Hungarian Civilization-Introduction to Chronology.

362. On tender basis for co-financing of publishing of books in Hungarian language, the Provincial Secretariat of Culture of AP of Vojvodina granted the funds for the issuance of the following publications:

\begin{tabular}{|c|c|c|}
\hline Publisher & Author/Title & Granted Funds \\
\hline $\begin{array}{l}\text { Lavik } 92 \text { Timp, } \\
\text { Bас̌ка Topola }\end{array}$ & Eva Harkai Vaš, Južno od Šarsega & $60,000.00$ \\
\hline $\begin{array}{l}\text { Petefi Šandor, } \\
\text { Hungarian Cultural } \\
\text { Association, Bečej }\end{array}$ & $\begin{array}{l}\text { Česak Balaž and Aniko Korčik, Cika ide párom-népi } \\
\text { gyermekjátékok Óbecséröl - Dečije narodne igre iz } \\
\text { Bečeja }\end{array}$ & $50,000.00$ \\
\hline Knesa, Kanjiža & $\begin{array}{l}\text { Group of authors, Antologija kolonije književnika u } \\
\text { Kanjiži }\end{array}$ & $60,000.00$ \\
\hline
\end{tabular}




\begin{tabular}{|c|c|c|}
\hline $\begin{array}{l}\text { Siveri Janoš, Art } \\
\text { Scene, Mužlja }\end{array}$ & Bela Tot, Dečije pesme & $20,000.00$ \\
\hline $\begin{array}{l}\text { Collegium of } \\
\text { University } \\
\text { Education of } \\
\text { Hungarians of } \\
\text { Vojvodina, Novi } \\
\text { Sad }\end{array}$ & $\begin{array}{l}\text { Eva Hoža, Novela u Vojvodini } \\
\text { Scientific student works, Konturi } \\
\text { Dr Žombor Labadi, Monografija o Janošu Siveriju }\end{array}$ & $\begin{array}{r}50,000.00 \\
150,000.00 \\
80,000.00\end{array}$ \\
\hline $\begin{array}{l}\text { Magyar Szó, Novi } \\
\text { Sad }\end{array}$ & Group of authors, Kralj Matija je živ & $60,000.00$ \\
\hline $\begin{array}{l}\text { Zetna, Association } \\
\text { of Citizens, Senta }\end{array}$ & $\begin{array}{l}\text { Jožef Fekete, Mit ér az irodalom, ha magyar? } \\
\text { Kristijan Tobijaš, Vasjani } \\
\text { Oto Tolnai, Knjižioca iz Sente } \\
\text { Ištvan Besedeš, VasionAzurna } \\
\text { Oto Fenjveši, Čitajući pokojnih Vojvođana }\end{array}$ & $\begin{array}{r}70,000.00 \\
50,000.00 \\
70,000.00 \\
30,000.00 \\
50,000.00\end{array}$ \\
\hline $\begin{array}{l}\text { Institute of Culture } \\
\text { of Hungarians of } \\
\text { vojvodina, Senta }\end{array}$ & $\begin{array}{l}\text { Group of authors, Društvena istraživanja iz aspekta } \\
\text { mađarske nacionalne zajednice - zajednička } \\
\text { perspektiva } \\
\text { Group of authors, Istorijski identitet - kulturološko } \\
\text { sećanje }\end{array}$ & $\begin{array}{l}70,000.00 \\
80,000.00\end{array}$ \\
\hline Publikum, Sombor & $\begin{array}{l}\text { Zoltan Kalapiš, Tragom prošlosti - ljudi, sudbine, } \\
\text { životopisi }\end{array}$ & $70,000.00$ \\
\hline $\begin{array}{l}\text { Social Organization } \\
\text { of the Arač Village } \\
\text { Culture, Subotica }\end{array}$ & Gubas Agata, Kamen temeljac - almanah društva & $70,000.00$ \\
\hline $\begin{array}{l}\text { Open University, } \\
\text { Subotica }\end{array}$ & $\begin{array}{l}\text { Geza Čat, Hátra maradt naplók } \\
\text { Geza Čat, Porodična pisma } 3 \\
\text { Mesaroš Zoltan, Propaganda ranog titoizma } \\
\text { Olga Kovačev Ninkov, Lepkék és repúölogépek avagy } \\
\text { farkasok és angyalok } \\
\text { Hosza Eva, Csath alle és kitérök } \\
\text { Deak Ferenc, Légszomj } \\
\text { Herceg Janos, Viharban }\end{array}$ & $\begin{array}{r}70,000.00 \\
40,000.00 \\
40,000.00 \\
35,000.00 \\
35,000.00 \\
25,000.00 \\
25,000.00\end{array}$ \\
\hline $\begin{array}{l}\text { Christian Youth of } \\
\text { Vojvodina, Subotica }\end{array}$ & Ekumenski teološki rečnik & $80,000.00$ \\
\hline $\begin{array}{l}\text { The Town Library, } \\
\text { Subotica }\end{array}$ & $\begin{array}{l}\text { Eva Hozka, Ninkov Kovačev Olga, Likovni album } \\
\text { Geze Čata }\end{array}$ & $90,000.00$ \\
\hline $\begin{array}{l}\text { Arač, Association } \\
\text { for Tradition } \\
\text { Forstering, Torda }\end{array}$ & $\begin{array}{l}\text { Mese Titku } \\
\text { Legende o crkvi Arač }\end{array}$ & $\begin{array}{l}20,000.00 \\
35,000.00\end{array}$ \\
\hline $\begin{array}{l}\text { Čokaški dobošari, } \\
\text { Cultural } \\
\text { Association, Čoka }\end{array}$ & Konja Šandor, Pesme za decu & $30,000.00$ \\
\hline
\end{tabular}


363. The Provincial Secretariat of Culture of AP of Vojvodina supported the publishing activities in Hungarian language (first editions of books, magazines, assistance to publishing activities of publishing houses). In 2007 it granted funds in the total amount of 8,644,604.00 dinars, in 2008 it granted 13,297,298.00 dinars and in 2009 it granted 13,996,028.00 dinars.

364. On tender basis for co-financing of the projects/programmes the quality of which contributes to the development and the presentation of art and culture of national minorities the Ministry of Culture supported the publishing activities in Hungarian language.

\begin{tabular}{|l|l|c|}
\hline \multicolumn{1}{|c|}{ Beneficiary } & \multicolumn{1}{|c|}{ Project } & Granted Funds \\
\hline Forum, Publishing Institute, Novi Sad & $\begin{array}{l}\text { Publishing of the book: Kornelije } \\
\text { Fargo, Komparativne poetike, } \\
\text { relacionalna značenja }\end{array}$ & $100,000.00$ \\
\hline $\begin{array}{l}\text { Collegium of University Education of } \\
\text { Hungarians of Vojvodina, Novi Sad }\end{array}$ & Publishing of the book:Ironija lebdenja & $50,000.00$ \\
\hline Zetna, Association of Citizens, Senta & $\begin{array}{l}\text { Projekat Makropolj, proze na četiri (ili } \\
\text { više) ruke }\end{array}$ & $50,000.00$ \\
\hline The Town Library, Subotica & $\begin{array}{l}\text { Publishing of the collected works from } \\
\text { the Seminar Dani Dežea Kostolanjija }\end{array}$ & $50,000.00$ \\
\hline $\begin{array}{l}\text { Kiš Lajoš, Ethnological Association, } \\
\text { Subotica }\end{array}$ & $\begin{array}{l}\text { Publishing of the book: J. Cvijić, } \\
\text { Balkansko poluostrvo i južnoslovenske } \\
\text { zemlje }\end{array}$ & $100,000.00$ \\
\hline $\begin{array}{l}\text { Open University Ltd. Radionica } \\
\text { Eletjel, Subotica }\end{array}$ & $\begin{array}{l}\text { Preporodi } \\
\text { Mesaroš Zoltan, Propaganda ranog }\end{array}$ & $100,000.00$ \\
\hline
\end{tabular}

365. Them, Newspaper Publishing Association from Novi Sad, which publishes 5-6 books annually receives subsidies for publishing activity in Romani language from the Provincial Secretariat of AP of Vojvodina. For these purposes, $200,000.00$ dinars were allocated in 2007, in 2008 the granted funds amounted to $228,000.00$ dinars and in 2009 they amounted to $228,000.00$ dinars.

366. The Table below contains the data about the co-financing of publishing activities in Romani language by the Provincial Secretariat of Culture of AP.

\begin{tabular}{|l|l|r|}
\hline \multicolumn{1}{|c|}{ Publisher } & \multicolumn{1}{|c|}{ Author/Title } & Granted Funds \\
\hline $\begin{array}{l}\text { RRomanine Jakha, } \\
\text { Romani Association } \\
\text { Vršac }\end{array}$ & $\begin{array}{l}\text { Dragica Tobej Kaldaraš, Tradicionalna poezija Roma } \\
\text { iz Vršca i okoline }\end{array}$ & $15,000.00$ \\
\hline $\begin{array}{l}\text { Association of } \\
\text { Romani Teachers of } \\
\text { Vojvodina, Deronje }\end{array}$ & $\begin{array}{l}\text { Ranko Rajko Jovanović, Antologija pesama romskih } \\
\text { pesnika vojvodine }\end{array}$ & $60,000.00$ \\
& Ranko Rajko Jovanović, Mi danas & $50,000.00$ \\
& Ranko Rajko Jovanović, Romske ptičice & $20,000.00$ \\
& Ranko Rajko Jovanović, Hoću da poletim & $35,000.00$ \\
\hline
\end{tabular}




\begin{tabular}{|l|l|r|}
\hline $\begin{array}{l}\text { RRomaninokhero, } \\
\text { Association of } \\
\text { Citizens, Sombor }\end{array}$ & Piroška Kovač, Romske bajke & $40,000.00$ \\
\hline $\begin{array}{l}\text { RRomanino Pustika- } \\
\text { Romske knjige, } \\
\text { Publishing House, }\end{array}$ & Alija Krasnići, Romske bajke & $100,000.00$ \\
Subotica & & \\
\hline $\begin{array}{l}\text { Romani Youth, Stari } \\
\text { Banovci }\end{array}$ & Group of authors, Znameniti Romi & $20,000.00$ \\
\hline
\end{tabular}

367. On tender basis for co-financing of the projects/programmes the quality of which contributes to the development and the presentation of art and culture of national minorities the Ministry of Culture supported the publishing activities in Romani language.

\begin{tabular}{|l|l|c|}
\hline \multicolumn{1}{|c|}{ Beneficiary } & \multicolumn{1}{|c|}{ Project } & Granted Funds \\
\hline $\begin{array}{l}\text { Romani emancipacija, Centre for } \\
\text { Education, Research and Social Care } \\
\text { for Roma, Belgrade }\end{array}$ & Romani abecedari-Romski bukvar & $150,000.00$ \\
\hline $\begin{array}{l}\text { Bare jaga, Association of Culture and } \\
\text { Education of Roma, Mačvanska } \\
\text { Mitrovica }\end{array}$ & Velike vatre & $50,000.00$ \\
\hline $\begin{array}{l}\text { Bahtale RRomani, Association of } \\
\text { Roma, Sombor }\end{array}$ & Ciganska majka, collection of poems & $80,000.00$ \\
\hline $\begin{array}{l}\text { RRomanine Pustika - Poмcke Kњuze, } \\
\text { Publiching Company, Subotica }\end{array}$ & Ciganin na konju a konja nema & $50,000.00$ \\
\hline $\begin{array}{l}\text { Multimedia Centre of Roma of Serbia, } \\
\text { trstenik }\end{array}$ & $\begin{array}{l}\text { Basne I bojanka (in Serbian and } \\
\text { Romani languages) }\end{array}$ & $60,000.00$ \\
\hline
\end{tabular}

368. In 2008 the Ministry of Human and Minority Rights allocated 80,000.00 dinars for the publishing of the book Bajke i bojanke, in Romani and Serbian languages.

369. The Provincial Secretariat of Culture of AP of Vojvodina subsidizes the publishing activity in Romanian language by Libertatea, Newspaper Publishing Association from Pančevo, which was founded by the National Council of the Romanian National Minority. This association publishes from 10-13 book a year. In 2007 this association was subsidized with 600,000.00 dinars and in 2008 the subsidy was in the amount of 1,600,000.00 dinars and in 2009 it amounted to $1,500,000.00$ dinars.

370. On tender basis for co-financing of publishing of books in Romanian language, the Provincial Secretariat of Culture of AP of Vojvodina granted the funds for the issuance of the following publications:

\begin{tabular}{|l|l|r|}
\hline \multicolumn{1}{|c|}{ Publisher } & \multicolumn{1}{c|}{ Author/Title } & Granted Funds \\
\hline $\begin{array}{l}\text { Association of } \\
\text { Romanian Language } \\
\text { of Vojvodina, Vršac }\end{array}$ & Marioara Baba, Antologija poezije Marije Vojnović & $20,000.00$ \\
\hline & $\begin{array}{l}\text { Petru Krdu, Saučesništvo } \\
\text { Ileana Ursu Nenedić, Riblji jezik }\end{array}$ & $70,000.00$ \\
& & $60,000.00$ \\
\hline
\end{tabular}




\begin{tabular}{|l|l|r|}
\hline $\begin{array}{l}\text { Libertatea, } \\
\text { Newspaper } \\
\text { Publishing } \\
\begin{array}{l}\text { Association, } \\
\text { Pančevo }\end{array}\end{array}$ & Marioara Stojanović, Veronika \\
& Kosta Rošu, Bibliografija nedeljnika Libertatea & $60,000.00$ \\
& Aurel Miok, Tečno polje & $60,000.00$ \\
Tibiskus, Uzdin & $\begin{array}{l}\text { Pavel Gatajancu, Paralelna čitanja } \\
\text { George Lifa, Doprinosi za monografiju folklore:doine I } \\
\text { pesme } \\
\text { Pavel Gatajancu, Izabrane pesme }\end{array}$ & $62,500.00$ \\
& $\begin{array}{l}\text { Ioan Čipu, Viđeniji ljudi iz srpskog dela Banata } \\
\text { Vasile Barbu, Stare reči banatskog govora Uzdina }\end{array}$ & $50,000.00$ \\
\hline
\end{tabular}

371. The Provincial Secretariat of Culture of AP of Vojvodina supported the publishing activities in Romanian language (first editions of books, magazines, assistance to publishing activities of publishing houses). In 2007 it granted funds in the total amount of 1,842,000.00 dinars, in 2008 it granted 2,220,000.00 dinars and in 2009 it granted 2,073,500.00 dinars.

372. On tender basis for co-financing of the projects/programmes the quality of which contributes to the development and the presentation of art and culture of national minorities the Ministry of Culture supported the publishing activity in Romanian language.

\begin{tabular}{|l|l|r|}
\hline \multicolumn{1}{|c|}{ Beneficiary } & \multicolumn{1}{|c|}{ Project } & Granted Funds \\
\hline $\begin{array}{l}\text { Andrej Šaguna, Literature-Artistic } \\
\text { Association of Romanians, Pančevo }\end{array}$ & Lepši deo naših sela & $50,000.00$ \\
& $\begin{array}{l}\text { Upoznajmo prošlost da bi bolje } \\
\text { sagledali budućnost }\end{array}$ & $30,000.00$ \\
\hline
\end{tabular}

373. Ruske slovo, Newspaper Publishing Association from Novi Sad, which is founded by the National Council of the Ruthenian National Minority, is the largest publisher of books in Ruthenian language. It published 21 books in the previous three years. In 2007, the Provincial Secretariat of Culture of AP of Vojvodina subsidized this publishing association with 600,000.00 dinars, in 2008 with $1,600,000.00$ dinars and in 2009 with 1,500,000.00 dinars.

374. On tender basis for co-financing of publishing of books in Ruthenian language, the Provincial Secretariat of Culture of AP of Vojvodina granted the funds for the issuance of the following publications:

\begin{tabular}{|c|c|c|}
\hline Publisher & Author/Title & Granted Funds \\
\hline $\begin{array}{l}\text { The Prometej, } \\
\text { Publishing House, } \\
\text { Novi Sad }\end{array}$ & Mihajlo Fejsa, Pravopisni rečnik rusinskog jezika & $30,000,00$ \\
\hline
\end{tabular}




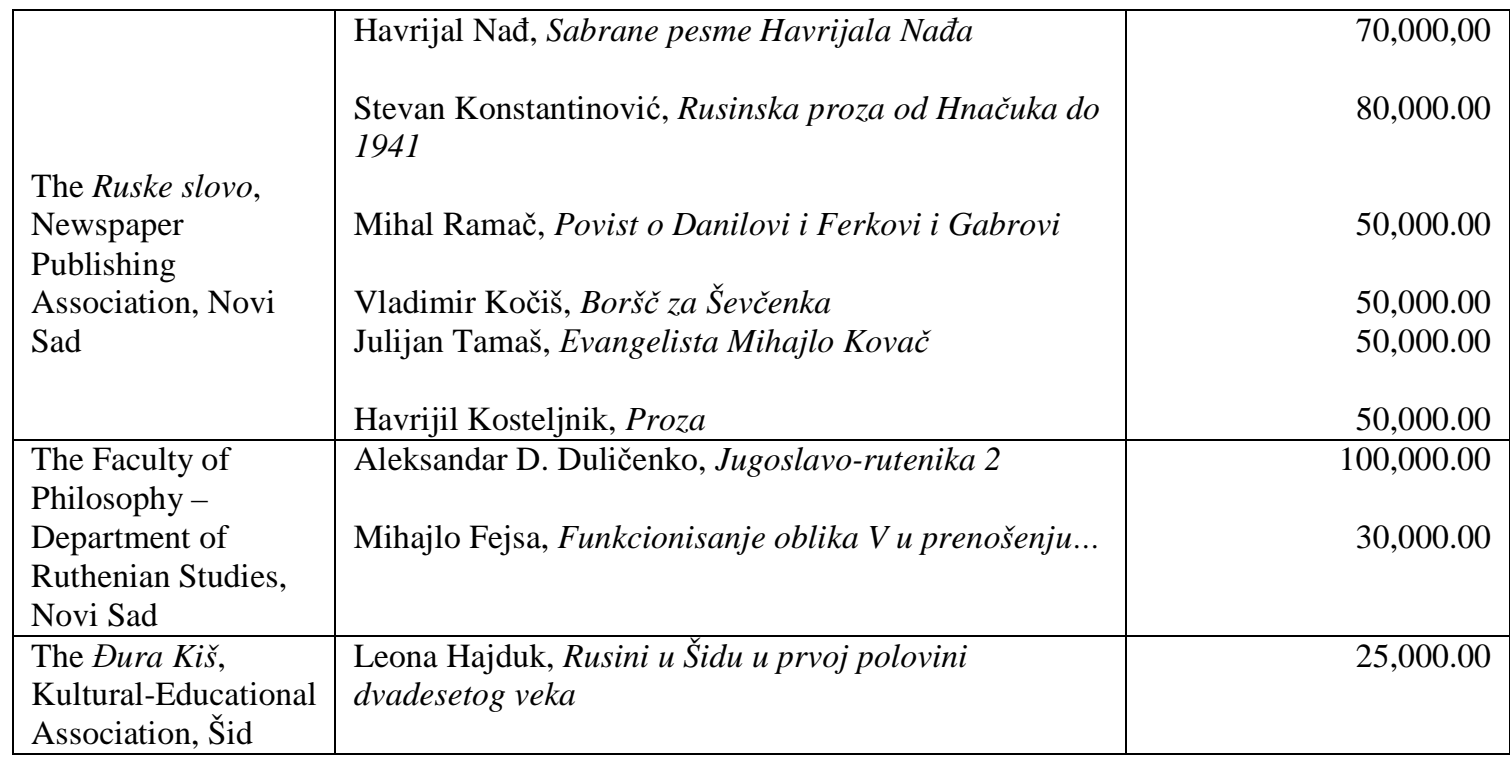

375. The Provincial Secretariat of Culture of AP of Vojvodina supported the publishing activities in Ruthenian language (first editions of books, magazines, assistance to publishing activities of publishing houses). In 2007 it granted funds in the total amount of 1,089,000.00 dinars, in 2008 it granted 2,170,000.00 dinars and in 2009 it granted 1,959,000.00 dinars.

376. On tender basis for co-financing of the projects/programmes the quality of which contributes to the development and the presentation of art and culture of national minorities the Ministry of Culture supported the publishing activity in Ruthenian language.

\begin{tabular}{|l|l|r|}
\hline \multicolumn{1}{|c|}{ Beneficiary } & \multicolumn{1}{|c|}{ Project } & Granted Funds \\
\hline $\begin{array}{l}\text { DOK Kucura, Cultural-Educational } \\
\text { Association, Kucura }\end{array}$ & $\begin{array}{l}\text { Pycuнu/Pycrauu/Ruthenians } \\
(1745-2005) 2^{\text {nd }} \text { and } 3^{\text {rd }} \text { book }\end{array}$ & $100,000.00$ \\
& Pravopisni rečnik rusinskog jezika & $30,000.00$ \\
\hline
\end{tabular}

377. Within the previous three years, the Slovak Publishing Centre from Bački Petrovac published 40 books in Slovak language. For this publishing activity the subsidies by the Provincial Secretariat of Culture of AP of Vojvodina amounted to $600,000.00$ dinars in 2007, in 2008 they amounted to 5,000,000.00 dinars and in 2009 they amounted to 2,000,000.00 dinars.

378. Hlas L'udu, Newspaper Publishing Association from Novi Sad which is founded by the National Council of the Slovak National Minority, within the same period issued 9 books, 3 books under the financial support by the Provincial Secretariat of Culture and 6 were funded from the fund of the Republic of Slovakia. 
379. On tender basis for co-financing of publishing of books in Slovak language, the Provincial Secretariat of Culture of AP of Vojvodina granted the funds for the issuance of the following publications:

\begin{tabular}{|c|c|c|}
\hline Publisher & Author/Title & Granted Funds \\
\hline $\begin{array}{l}\text { The Kultura, } \\
\text { Printing Company, } \\
\text { Bački Petrovac }\end{array}$ & $\begin{array}{l}\text { Andrej Kopčok, Filozofsko-sociološke studije } \\
\text { Adam Svetlik, Poezia vojvodinskih slovakov v druhej } \\
\text { polovici 20. Storočia }\end{array}$ & $60,000,00$ \\
\hline $\begin{array}{l}\text { Slovak Publishing } \\
\text { Centre, Bački } \\
\text { Petrovac }\end{array}$ & $\begin{array}{l}\text { Marija Kotvašova Jonašova, Mama, ajde da se igramo } \\
\text { Jan Marko, Rečnik slovačkih univerzitetskih pedagifga } \\
\text { Ana Kukučkova, Chostik a kamarati } \\
\text { Adam Svetlik, Antologija slovačke vojvođanske } \\
\text { postmoderne proze } \\
\text { Mihal Harpanj, Predslovy a doslovy }\end{array}$ & $\begin{array}{l}50,000.00 \\
32,500.00 \\
20,000.00 \\
40,000.00 \\
30,000.00\end{array}$ \\
\hline $\begin{array}{l}\text { Slovak Evangelistic } \\
\text { Church, bingula }\end{array}$ & Stanislav Stupavski, Slovaci u Binguli & $40,000.00$ \\
\hline $\begin{array}{l}\text { Cultural Centre, } \\
\text { Zrenjanin }\end{array}$ & Marija Harmat, Pogled sa mirisom vanile & $70,000.00$ \\
\hline $\begin{array}{l}\text { The Hlas Ljudu, } \\
\text { Newspaper } \\
\text { Publishing } \\
\text { Association, Novi } \\
\text { Sad }\end{array}$ & $\begin{array}{l}\text { Marija Kotvaš Janoš, Striptiz } \\
\text { Vićezoslav Hronjec, Antologija poezije časopisa Vzlet }\end{array}$ & $\begin{array}{l}40,000.00 \\
50,000.00\end{array}$ \\
\hline $\begin{array}{l}\text { Širka Projects Ltd., } \\
\text { Padina }\end{array}$ & $\begin{array}{l}\text { Martin Slivka, Život u pustinji } \\
\text { Ružena Kraćica, Zbirka poezije }\end{array}$ & $\begin{array}{l}40,000.00 \\
15,000.00\end{array}$ \\
\hline $\begin{array}{l}\text { The Hleba i igara, } \\
\text { Art Centre, Stara } \\
\text { Pazova }\end{array}$ & Vićezoslav Hronjec, Pesma - Granica I & $40,000.00$ \\
\hline
\end{tabular}

380. The Provincial Secretariat of Culture of AP of Vojvodina supported the publishing activities in Slovak language (first editions of books, magazines, assistance to publishing activities of publishing houses). In 2007 it granted funds in the total amount of 3,602,000.00 dinars, in 2008 it granted 5,615,000.00 dinars and in 2009 it granted 2,435,500.00 dinars.

381. On tender basis for co-financing of the projects/programmes the quality of which contributes to the development and the presentation of art and culture of national minorities the Ministry of Culture supported the publishing activity in Slovak language.

\begin{tabular}{|l|l|r|}
\hline \multicolumn{1}{|c|}{ Beneficiary } & \multicolumn{1}{|c|}{ Project } & Granted Funds \\
\hline $\begin{array}{l}\text { The Selenča, Association for } \\
\text { Preservation of Culture, Tradition and } \\
\text { Art, Selenča }\end{array}$ & Selenča $1758-2008$, monography & $200,000.00$ \\
\hline
\end{tabular}


382. Ridne slovo, Newspaper Publishing Association from Novi Sad, which is founded by the National Council of the Ukrainian National Minority publishes books in Ukrainian language.

383. On tender basis for co-financing of publishing of books in Ukrainian language, the Provincial Secretariat of Culture of AP of Vojvodina granted the funds for the issuance of the following publications:

\begin{tabular}{|c|c|c|}
\hline Publisher & Author/Title & Granted Funds \\
\hline $\begin{array}{l}\text { The Ridne slovo, } \\
\text { Newspaper } \\
\text { Publishing } \\
\text { Association, Kula }\end{array}$ & Zbirka poetskih i proznih dela Eugena Kuleba & $35,000.00$ \\
\hline $\begin{array}{l}\text { The Prosvita, } \\
\text { Association of } \\
\text { Ukrainian Language, } \\
\text { Literature and } \\
\text { Culture, Novi Sad }\end{array}$ & $\begin{array}{l}\text { Oleg Rumjancev, Istorija Ukrajinaca na prostorima } \\
\text { bivše Jugoslavije } \\
\text { Kaća Dejanović, Do zabavi }\end{array}$ & $\begin{array}{l}65,000.00 \\
70,000.00\end{array}$ \\
\hline Ivan Terljuk & Paša u blatu & $40,000.00$ \\
\hline
\end{tabular}

384. The Provincial Secretariat of Culture of AP of Vojvodina supported the publishing activities in Ukrainian language (first editions of books, magazines, assistance to publishing activities of publishing houses). In 2007 it granted funds in the total amount of 65,500.00 dinars, in 2008 it granted 90,000.00 dinars and in 2009 it granted 130,000.00 dinars.

385. In the previous three years, Hrvatska riječ, Newspaper Publishing Association from Subotica published 18 books in Croatian language. The Provincial Secretariat of Culture of AP of Vojvodina subsidized the publishing of the books in Croatian language of this publisher with 300,000.00 dinars. In 2008 the subsidy amounted to $300,000.00$ dinars and in 2009 to $750,000.00$ dinars.

386. On tender basis for co-financing of publishing of books in Croatian language, the Provincial Secretariat of Culture of AP of Vojvodina granted the funds for the issuance of the following publications:

\begin{tabular}{|c|c|c|}
\hline Publisher & Author/Title & Granted Funds \\
\hline $\begin{array}{l}\text { The Stanislav } \\
\text { Preprek, Croatian } \\
\text { Cultural-Artistic } \\
\text { Association, Novi } \\
\text { Sad }\end{array}$ & $\begin{array}{l}\text { Jelisaveta Buljovčić, Draga sićanja } \\
\text { Zvonimir Vuković, Petrovaradin juče, danas i sutra }\end{array}$ & $\begin{array}{l}15,000.00 \\
30,000.00\end{array}$ \\
\hline $\begin{array}{l}\text { The Matica } \\
\text { Hrvatska, Subotica }\end{array}$ & $\begin{array}{l}\text { Group of authors, Matica hrvatska u Subotici } \\
\text { Lazar Merković, Bio-bibliografija književnog časopisa } \\
\text { Klasja naših ravni } \\
\text { Milovan Miković, Antologija hrvatskog romana u } \\
\text { Vojvodini }\end{array}$ & $\begin{array}{r}40,000.00 \\
40,000.00 \\
35,000.00\end{array}$ \\
\hline & Group of authors, Leksikon podunavskih hrvata, & $40,000.00$ \\
\hline
\end{tabular}




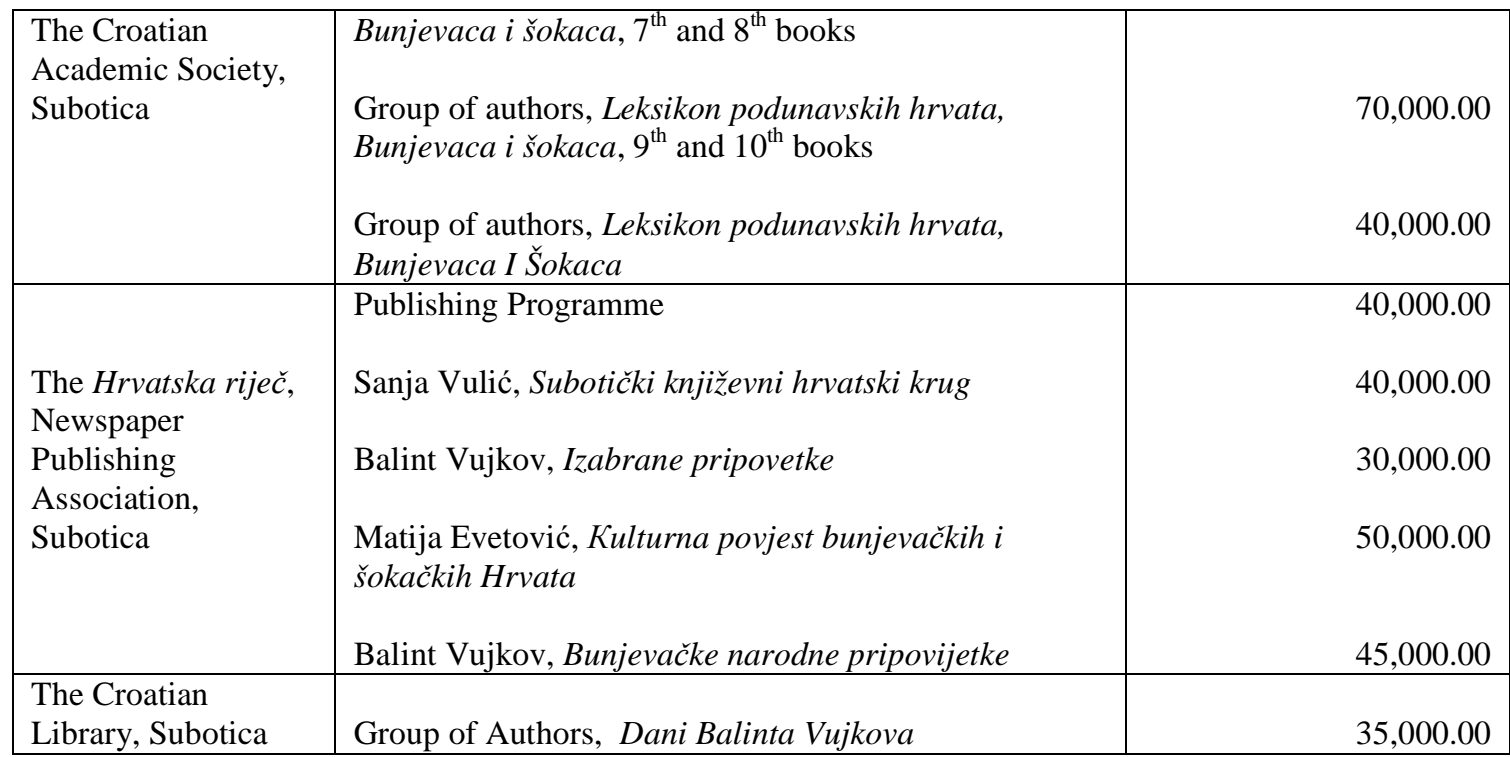

387. The Provincial Secretariat of Culture of AP of Vojvodina supported the publishing activities in Croatian language (first editions of books, magazines, assistance to publishing activities of publishing houses). In 2007 it granted funds in the total amount of 567,000.00 dinars, in 2008 it granted 810,000.00 dinars and in 2009 it granted 1,129,000.00 dinars.

388. On tender basis for co-financing of the projects/programmes the quality of which contributes to the development and the presentation of art and culture of national minorities the Ministry of Culture supported the Croatian Academic Association from Subotica with 90,000.00 dinars for the publishing of Leksikon podunavskih Hrvata - Bunjevaca $i$ Šokaca ( $7^{\text {th }}$ and $8^{\text {th }}$ book).

389. In order to promote awareness and tolerance in the Serbian society as a whole in respect of minority languages and cultures they represent, publishing of books in several languages is co-financed in the Republic of Serbia. On tender basis for cofinancing of publishing of books in AP of Vojvodina, the Provincial Secretariat of Culture granted the funds for the co-financing of the issuance of the following book in several minority languages:

\begin{tabular}{|c|c|c|c|}
\hline Publisher & Author/Title & $\begin{array}{l}\text { Publishing } \\
\text { Language }\end{array}$ & Granted Funds \\
\hline $\begin{array}{l}\text { The Jedinstvo, } \\
\text { Bajmok }\end{array}$ & Ranko Radulović, 50 godina zajedno & Serbian, Hungarian & $25,000.00$ \\
\hline $\begin{array}{l}\text { The Bačka } \\
\text { Topola, } \\
\text { Publishing } \\
\text { Company, Bačka } \\
\text { Topola }\end{array}$ & $\begin{array}{l}\text { Group of authors, Bačkotopolski kipovi } \\
\text { i spomen ploče }\end{array}$ & Serbian, Hungarian & $40,000.00$ \\
\hline $\begin{array}{l}\text { Association of } \\
\text { Romanian }\end{array}$ & $\begin{array}{l}\text { Aurora Rotariu Planjanin, Seča drva } \\
\text { (Dedin konj) }\end{array}$ & Serbian, Romanian & $20,000.00$ \\
\hline
\end{tabular}




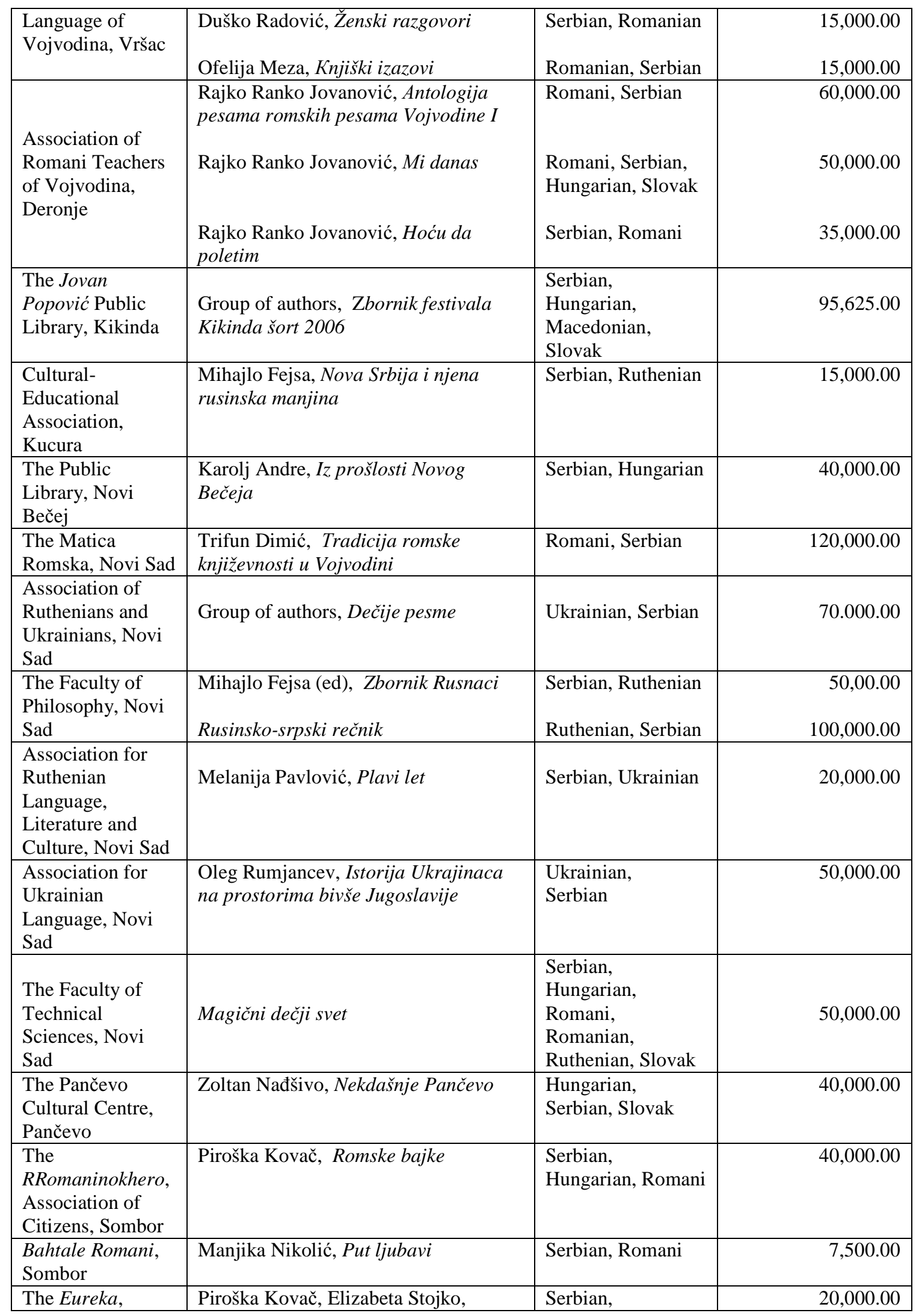




\begin{tabular}{|c|c|c|c|}
\hline $\begin{array}{l}\text { Association of } \\
\text { Citizens, Sombor }\end{array}$ & Istinite priče naših života & Hungarian, Romani & \\
\hline $\begin{array}{l}\text { The Moravički } \\
\text { Intelektualni krug, } \\
\text { Stara Moravica }\end{array}$ & $\begin{array}{l}\text { Olga Kovačev Ninkov, Multietnička } \\
\text { kolonija 9+1-30godina postojanja }\end{array}$ & Serbian, Hungarian & $40,000.00$ \\
\hline $\begin{array}{l}\text { The Romska } \\
\text { omladina danas - } \\
\text { ROD, Stari } \\
\text { Banovci }\end{array}$ & Znameniti Romi Srema & Serbian, Romani & $20,000.00$ \\
\hline $\begin{array}{l}\text { The Bunjevačka } \\
\text { Matica, Subotica }\end{array}$ & $\begin{array}{l}\text { Ivan Bašić Palković, Dida pripovidaj } \\
m i\end{array}$ & Bunjevac, Serbian & $50,000.00$ \\
\hline $\begin{array}{l}\text { Marija Cindori } \\
\text { Šinković, Subotica }\end{array}$ & $\begin{array}{l}\text { Monografija časopisa Neven sa } \\
\text { bibliografijom }\end{array}$ & $\begin{array}{l}\text { Bunjevac, } \\
\text { Serbian }\end{array}$ & $70,000.00$ \\
\hline $\begin{array}{l}\text { Grafoprodukt } \\
\text { Ltd., Trade, } \\
\text { Production and } \\
\text { Services } \\
\text { Company, } \\
\text { Subotica }\end{array}$ & $\begin{array}{l}\text { Marija Cindori, Eva Bažant and } \\
\text { Nevenka Bašić Palković, Kalendari za } \\
\text { Bunjevce I Šokce (1851-1914) } \\
\text { bibliografija sa uvodnom studijom } \\
\text { Marija Cindori, Poglavlje vojvođanske } \\
\text { avangarde - subotički dadaistički } \\
\text { matine } 1922\end{array}$ & $\begin{array}{l}\text { Serbian, Bunjevac } \\
\text { Serbian, Hungarian }\end{array}$ & $35,000.00$ \\
\hline
\end{tabular}

\subsubsection{Cultural manifestations}

390. Various cultural manifestations held in all communities with the speakers of minority languages also contribute to preservation, affirmation and availability of minority languages in the Republic of Serbia. The following paragraphs of this Report contain the data about the cultural manifestations related to minority languages encouraged and financially supported by the State.

391. On tender basis for co-financing of the projects/programmes the quality of which contributes to the development and the presentation of art and culture of national minorities, the Ministry of Culture supported the cultural manifestation related to Albanian language - The 2009 Festival of Albanian Comedy with 70,000.00 dinars, which is organized by the Abdula Krašnica, Cultural Centre from Preševo.

392. On tender basis for co-financing of the projects/programmes the quality of which contributes to the development and the presentation of art and culture of national minorities, the Ministry of Culture supported the cultural manifestations related to Bosniak language.

\begin{tabular}{|l|l|r|}
\hline \multicolumn{1}{|c|}{ Beneficiary } & \multicolumn{1}{|c|}{ Project } & Granted Funds \\
\hline & $\begin{array}{l}\text { Festival sandžačke sevdalinke Fess } \\
2007\end{array}$ & $1,960,000.00$ \\
$\begin{array}{l}\text { The National Council of the Bosniak } \\
\text { National Minority, Novi Pazar }\end{array}$ & $\begin{array}{l}\text { Smotra bošnjačkih narodnih igara } \\
\text { SBONI }\end{array}$ & $1,500,000.00$ \\
& Sandžački književni susreti SAKS 2007 \\
& Bajramske svečanosti 2008 & $950,000.00$ \\
&
\end{tabular}


393. On tender basis for co-financing of the projects/programmes the quality of which contributes to the development and the presentation of art and culture of national minorities, the Ministry of Culture supported the cultural manifestations related to Bulgarian language.

\begin{tabular}{|l|l|r|}
\hline \multicolumn{1}{|c|}{ Beneficiary } & \multicolumn{1}{|c|}{ Project } & Granted Funds \\
\hline $\begin{array}{l}\text { The Carska Bara Foundation, Belo } \\
\text { Blato }\end{array}$ & $\begin{array}{l}\text { The Bugarijada - Festival of Bulgarian } \\
\text { Culture in the Central Banat }\end{array}$ & $50,000.00$ \\
\hline $\begin{array}{l}\text { The Detko Petrov Public Library, } \\
\text { Dimitrovgrad }\end{array}$ & Kroz vrata reči & $50,000.00$ \\
& Susret pod starom lipom, manifestation & $50,000.00$ \\
\hline The Balkan Association, Niš & Senokos 2009 & $50,000.00$ \\
\hline
\end{tabular}

394. The Table below contains the data about the funds granted for co-financing of the manifestations related to Bulgarian language according to the individual applications submitted to the tenders issued by the Provincial Secretariat of Culture of AP of Vojvodina.

\begin{tabular}{|l|l|r|}
\hline \multicolumn{1}{|c|}{ Beneficiary } & \multicolumn{1}{c|}{ Purpose } & Granted Funds \\
\hline Association for Bulgarian Language, & The Bugarijada in Vojvodina & $140,000.00$ \\
Literature and Culture, Novi Sad & $\begin{array}{l}150^{\text {th }} \text { Anniversary of the Dnevnica } \\
\text { Bulgarian newspaper }\end{array}$ & $30,000.00$ \\
& Sombor u očuvanju bugarske kulture & $10,000.00$ \\
\hline
\end{tabular}

395. On tender basis for co-financing of the projects/programmes the quality of which contributes to the development and the presentation of art and culture of national minorities, the Ministry of Culture supported the cultural manifestations related to Hungarian language.

\begin{tabular}{|l|l|r|}
\hline \multicolumn{1}{|c|}{ Beneficiary } & \multicolumn{1}{|c|}{ Project } & Granted Funds \\
\hline $\begin{array}{l}\text { The Sarvaš Gabor, Association for } \\
\text { Hungarian Language, Ada }\end{array}$ & $\begin{array}{l}\text { The Sarvaš Gabor Ada 2007 Linguistic } \\
\text { Manifestation }\end{array}$ & $100,000.00$ \\
\hline $\begin{array}{l}\text { The Petefi Šandor, Cultural Club, } \\
\text { Bečej }\end{array}$ & $\begin{array}{l}44^{\text {th }} \text { Folklore Festival - } \\
\text { Gyöngyösbokréta and 31 } \\
\text { Durindó Festival }\end{array}$ & $200,000.00$ \\
\hline $\begin{array}{l}\text { The Petefi Šandor, Cultural Club, } \\
\text { Dobričevo }\end{array}$ & $\begin{array}{l}\text { Festival of Hungarian Cultural-Artistic } \\
\text { Associations of the South Banat }\end{array}$ & $30,000.00$ \\
\hline The Egyseg, Cultural Club, Kikinda & $\begin{array}{l}45^{\text {th }} \text { Folklore Festival - } \\
\text { Gyöngyösbokréta and 32 }\end{array}$ & $200,000.00$ \\
Durindó Festival & $10,000.00$ \\
\hline The Public Library, Mali Iđoš & Days of Hungarian Culture in Mali Iđoš & $140,000.00$ \\
\hline $\begin{array}{l}\text { The Domboš, Association of Citizens, } \\
\text { Mali Iđoš }\end{array}$ & Domboš fest 2008 & $100,000.00$ \\
\hline $\begin{array}{l}\text { Association of Hungarian Teachers of } \\
\text { Vojvodina, Novi Sad }\end{array}$ & $\begin{array}{l}\text { Mother Tongue Fostering Summer } \\
\text { Camp }\end{array}$ & $30,000.00$ \\
\hline $\begin{array}{l}\text { The Abbazia, Association of Citizens, } \\
\text { Palić }\end{array}$ & $\begin{array}{l}2^{\text {nd }} \text { Carpathian Festival of Hungarian } \\
\text { Choirs }\end{array}$ & \\
\hline
\end{tabular}




\begin{tabular}{|l|l|r|}
\hline $\begin{array}{l}\text { Cultural Association of Hungarians of } \\
\text { Vojvodina, Subotica }\end{array}$ & $\begin{array}{l}14^{\text {th }}, 15^{\text {th }} \text { and } 16^{\text {th }} \text { Days of Culture of } \\
\text { Hungarians of Vojvodina }\end{array}$ & $190,000.00$ \\
\hline $\begin{array}{l}\text { The Nepker, Hungarian Cultural } \\
\text { Centre, Subotica }\end{array}$ & The Nepker $-135^{\text {th }}$ Anniversary & $50,000.00$ \\
Interetno Festival 2009 & $300,000.00$ \\
\hline
\end{tabular}

396. Within the tenders issued by the Provincial Secretariat of Culture of AP of Vojvodina the below stated manifestations related to Hungarian language were supported.

\begin{tabular}{|c|c|c|}
\hline Beneficiary & Purpose & Granted Funds \\
\hline $\begin{array}{l}\text { The Sarvaš Gabor, Association for } \\
\text { Hungarian Language, Ada }\end{array}$ & $\begin{array}{l}\text { The Sarvaš Gabor Linguistic } \\
\text { Manifestation }\end{array}$ & $110,000.00$ \\
\hline $\begin{array}{l}\text { The Kodalj Zoltan, Hungarian Cultural } \\
\text { Centre, Bačka Topola }\end{array}$ & $\begin{array}{l}5^{\text {th }} \text { and } 6^{\text {th }} \text { Festival of National } \\
\text { Minorities }\end{array}$ & $75,000.00$ \\
\hline $\begin{array}{l}\text { The Puls, Association of Citizens, } \\
\text { Bezdan }\end{array}$ & Festival of Hungarian Poetry & $30,000.00$ \\
\hline $\begin{array}{l}\text { The Carska Bara Foundation, Belo } \\
\text { Blato }\end{array}$ & $\begin{array}{l}\text { Festival of Hungarian Artists in Belo } \\
\text { Blato }\end{array}$ & $30,000.00$ \\
\hline $\begin{array}{l}\text { The Petefi Šandor, Hungarian } \\
\text { Cultural-Artistic Association, Bečej }\end{array}$ & Durindó and $44^{\text {th }}$ Gyöngyösbokréta & $250,000.00$ \\
\hline $\begin{array}{l}\text { The Petefi Šandor, Cultural-Artistic } \\
\text { Association, Budisava }\end{array}$ & $\begin{array}{l}\text { The Barangolo, } 3^{\text {rd }} \text { and } 4^{\text {th }} \text { Festival of } \\
\text { Diaspora Reciters }\end{array}$ & $60,000.00$ \\
\hline $\begin{array}{l}\text { The Petefi, Cultural-Artistic } \\
\text { Association, Zrenjanin }\end{array}$ & The $B$. Sabo Đerđa Manifestation & $90,000.00$ \\
\hline $\begin{array}{l}\text { The Lavanda, Folklore Manufacture, } \\
\text { Kanjiža }\end{array}$ & $\begin{array}{l}7^{\text {th }} \text { and } 8^{\text {th }} \text { Manifestation of Tradition in } \\
\text { Kanjiža }\end{array}$ & $60,000.00$ \\
\hline $\begin{array}{l}\text { The Petefi Šandor, Cultural-Artistic } \\
\text { Association, Mali Iđoš }\end{array}$ & Durindó and $46^{\text {th }}$ Gyöngyösbokréta & $150,000.00$ \\
\hline $\begin{array}{l}\text { Association of Hungarian Teachers of } \\
\text { Vojvodina, Novi Sad }\end{array}$ & $\begin{array}{l}11^{\text {th }} \text { and } 12^{\text {th }} \text { Festival of Children's } \\
\text { Folklore Groups }\end{array}$ & $85,000.00$ \\
\hline $\begin{array}{l}\text { Association of Hungarian Civil } \\
\text { Organizations of the South-Bačka and } \\
\text { Srem, Novi Sad }\end{array}$ & $\begin{array}{l}4^{\text {th }} \text { Festival of Cultural Clubs from } \\
\text { Srem } \\
\text { 3th Festival of Cultural Clubs from the } \\
\text { South Bačka } \\
\text { Hungarian Cultural Festivals in Srem }\end{array}$ & $\begin{array}{l}85,000.00 \\
90,000.00\end{array}$ \\
\hline $\begin{array}{l}\text { Association of Hungarian } \\
\text { Organization of the South-Bačka and } \\
\text { Srem, Novi Sad }\end{array}$ & $\begin{array}{l}\text { Hungarian Cultural Festivals in the } \\
\text { South Bačka }\end{array}$ & $40,000.00$ \\
\hline $\begin{array}{l}\text { The Petefi Šandor, Hungarian } \\
\text { Cultural-Artistic Association, Novi } \\
\text { Sad }\end{array}$ & $\begin{array}{l}5^{\text {th }} \text { Regional Festival of Hungarian } \\
\text { Cultural Clubs of the South Bačka and } \\
\text { Srem } \\
\text { Reč čuva jezik, manifestation }\end{array}$ & $35,000.00$ \\
\hline The Theatre of Novi Sad, Novi Sad & $\begin{array}{l}8^{\text {th }} \text { and } 9^{\text {th }} \text { Competition of Hungarian } \\
\text { Drama Writers of Vojvodina }\end{array}$ & $155,000.00$ \\
\hline $\begin{array}{l}\text { The Feher Ferenc, Hungarian } \\
\text { Cultural-Artistic Association, } \\
\text { Rumenka }\end{array}$ & Festival of Hungarian Culture & $81,000.00$ \\
\hline $\begin{array}{l}\text { The Turzo Lajoš, Cultural-Educational } \\
\text { Centre, Senta }\end{array}$ & $\begin{array}{l}\text { The Kalamanj Lajoš } 13 \text { th, } 14^{\text {th }} \text { and } 15^{\text {th }} \\
\text { Ethno-novel Competition }\end{array}$ & $95,000.00$ \\
\hline The Zetna, Association of Citizens & The Živa antologija autora Zetna & $90,000.00$ \\
\hline
\end{tabular}




\begin{tabular}{|l|l|r|}
\hline & Razgovori pod vulkanom & $90,000.00$ \\
\hline $\begin{array}{l}\text { The Senteleki, Hungarian Cultural- } \\
\text { Singing Association, Sivac }\end{array}$ & The Senteleki's Days & $205,000.00$ \\
\hline $\begin{array}{l}\text { Cultural Association of Hungarians of } \\
\text { Vojvodina, Subotica }\end{array}$ & $\begin{array}{l}14^{\text {th }} \text { and } 15^{\text {th }} \text { Cultural Festival of } \\
\text { Hungarians of Vojvodina } \\
\text { Festival of Hungarian Culture }\end{array}$ & $200,000.00$ \\
\hline The Town Library, Subotica & The Kostlanji Deže's Days & $220,000.00$ \\
\hline $\begin{array}{l}\text { Christian Youth of Vojvodina, } \\
\text { Subotica }\end{array}$ & Festival of Hungarian Cinematography & $145,000.00$ \\
\hline $\begin{array}{l}\text { Hungarian Youth of Vojvodina, } \\
\text { Subotica }\end{array}$ & Festival of Hungarian Christian Culture & $30,000.00$ \\
\hline $\begin{array}{l}\text { The Petefi Šandor, Cultural-Artistic } \\
\text { Association, Torda }\end{array}$ & Festival of Hungarian Film & $30,000.00$ \\
\hline $\begin{array}{l}\text { The Torontaltorda, Town } \\
\text { Development Foundation, Torda }\end{array}$ & $8^{\text {th }}$ Festival of Torda Culture & $550,000.00$ \\
\hline $\begin{array}{l}\text { Association of Hungarian Recitors of } \\
\text { Vojvodina, Feketić }\end{array}$ & $\begin{array}{l}\text { Semi-finals of International } \\
\text { Competition of Recitors }\end{array}$ & $30,000.00$ \\
\hline $\begin{array}{l}\text { The Adi Endre, Cultural-Singing } \\
\text { Association, Sušara }\end{array}$ & $\begin{array}{l}20^{\text {th }} \text { Festival of Cultural Clubs of the } \\
\text { South Banat }\end{array}$ & $25,000.00$ \\
\hline
\end{tabular}

397. On tender basis for co-financing of the projects/programmes the quality of which contributes to the development and the presentation of art and culture of national minorities, the Ministry of Culture supported the cultural manifestations related to Romani language.

\begin{tabular}{|l|l|r|}
\hline \multicolumn{1}{|c|}{ Beneficiary } & \multicolumn{1}{|c|}{ Project } & Granted Funds \\
\hline $\begin{array}{l}\text { The Sećanje, pomirenje i budućnost, } \\
\text { the Roma Holocaust Foundation, } \\
\text { Belgrade }\end{array}$ & Romani Literature & $80,000.00$ \\
\hline $\begin{array}{l}\text { Association of Citizens of Veliko } \\
\text { Gradište, Veliko Gradište }\end{array}$ & Roma Festival of the Danube Countries & $300,000.00$ \\
\hline $\begin{array}{l}\text { Association of Roma Teachers of } \\
\text { Vojvodina, Deronje }\end{array}$ & Festival of Romani Recitors & $50,000.00$ \\
\hline $\begin{array}{l}\text { The Pharlipe-Novi Sad, Association of } \\
\text { Citizens, Novi Sad }\end{array}$ & The Trifun Dimić's Poetry Days & $100,000.00$ \\
\hline $\begin{array}{l}\text { The Polis Fest, Associationof } \\
\text { Citizens, Subotica }\end{array}$ & $\begin{array}{l}\text { ROMART, International festival of } \\
\text { Romani Culture }\end{array}$ & $100,000.00$ \\
\hline $\begin{array}{l}\text { Association of Roma Democratization } \\
\text { and Education, Trstenik }\end{array}$ & The Dr Sava Stanojević's Days & $355,000.00$ \\
\hline $\begin{array}{l}\text { The Daydream, Association of } \\
\text { Citizens, Užice }\end{array}$ & $\begin{array}{l}\text { Festival of Romani Literature } \\
\text { Production }\end{array}$ & $50,000.00$ \\
\hline
\end{tabular}

398. In 2009 the Ministry of Human and Minority Rights allocated 50,000.00 dinars to the Association of Roma of the Pčinjsko-Jablanički District to organize the Eighth Festival of Cultural Achievements of Roma.

399. The Table below contains the data about the funds granted for co-financing of the cultural manifestations related to Romani language according to the individual 
applications submitted to the tenders issued by the Provincial Secretariat of Culture of AP of Vojvodina.

\begin{tabular}{|l|l|r|}
\hline \multicolumn{1}{|c|}{ Beneficiary } & \multicolumn{1}{|c|}{ Purpose } & Granted Funds \\
\hline The Romani Cultural Centre, Beočin & Preservation of Culture and Tradition & $20,000.00$ \\
\hline $\begin{array}{l}\text { The Beočin, Association of Roma, } \\
\text { Beočin }\end{array}$ & The Roma Day & $20,000.00$ \\
\hline $\begin{array}{l}\text { The Ciganske oči, Association of } \\
\text { Roma, Vršac }\end{array}$ & $\begin{array}{l}\text { Cultural Manifestation of the Roma of } \\
\text { Vršac }\end{array}$ & $15,000.00$ \\
\hline $\begin{array}{l}\text { The RRomanine jakha, Association of } \\
\text { Roma, Vršac }\end{array}$ & $\begin{array}{l}\text { Cultural Manifestation of the Roma of } \\
\text { Vršac }\end{array}$ & $17,500.00$ \\
\hline $\begin{array}{l}\text { Association of Roma Teachers, } \\
\text { Deronje }\end{array}$ & $\begin{array}{l}\text { Festival of Romani Recitors of } \\
\text { Vojvodina }\end{array}$ & $120,000.00$ \\
\hline $\begin{array}{l}\text { The Amaro Kham, Association of } \\
\text { Citizens, Kikinda }\end{array}$ & Romani Festival & $40,000.00$ \\
\hline $\begin{array}{l}\text { The Romani Network of Novi Sad, } \\
\text { Novi Sad }\end{array}$ & $\begin{array}{l}\text { Cultural Manifestation of the Roma of } \\
\text { Vojvodina }\end{array}$ & $80,000.00$ \\
\hline $\begin{array}{l}\text { The Danica, Association of Roma, } \\
\text { Pančevo }\end{array}$ & Romani Literature Evening & $15,000.00$ \\
\hline $\begin{array}{l}\text { Forum of Romani NGOs, Sombor } \\
\text { The Rom, Cultural-Artistic } \\
\text { Association, Srbobran }\end{array}$ & $\begin{array}{l}\text { Modern Culture of the Roma of the } \\
\text { Municipality of Sombor }\end{array}$ & $20,000.00$ \\
\hline $\begin{array}{l}\text { Centre of Romani Culture, Subotica } \\
\text { Romska Omladina Danas, Stari } \\
\text { Banovci }\end{array}$ & The Ciganske vatre & $55,000.00$ \\
\hline & Phe First Poetry Festival of the Roma & $15,000.00$ \\
\hline
\end{tabular}

400. On tender basis for co-financing of the projects/programmes the quality of which contributes to the development and the presentation of art and culture of national minorities, the Ministry of Culture supported the cultural manifestations related to Romanian language.

\begin{tabular}{|l|l|r|}
\hline \multicolumn{1}{|c|}{ Beneficiary } & \multicolumn{1}{|c|}{ Project } & Granted Funds \\
\hline The Tibiskus, Literature-Artistic & The Putevi Klasja, International Poetry & $75,000.00$ \\
Association, Uzdin & Festival & $15,000.00$ \\
& $\begin{array}{l}\text { The Znameniti Banaćani, International } \\
\text { Symposium }\end{array}$ & \\
\hline
\end{tabular}

401. Within the tenders issued by the Provincial Secretariat of Culture of AP of Vojvodina the below stated manifestations related to Romanian language were supported.

\begin{tabular}{|l|l|r|}
\hline \multicolumn{1}{|c|}{ Beneficiary } & \multicolumn{1}{c|}{ Purpose } & Granted Funds \\
\hline $\begin{array}{l}\text { Association for Romanian Language } \\
\text { of Vojvodina, Novi Sad }\end{array}$ & The Radu Flora Memorial & $75,000.00$ \\
\hline & $\begin{array}{l}\text { The Jon Nice Sekošan, } 1^{\text {st }} \text { and 2 } \\
\text { International Festival of Production in } \\
\text { Romanian Banat Dialect }\end{array}$ & $45,000.00$ \\
The Vikentije Petrović Bokaluc, & $1^{\text {st }}$ and $2^{\text {nd }}$ International Festival of & $40,000.00$ \\
\hline
\end{tabular}




\begin{tabular}{|l|l|r|}
\hline Cultural Club, Torak & $\begin{array}{l}\text { Romanian Epigram Writers } \\
8^{\text {th }} \text { and } 9^{\text {th }} \text { International Humour and } \\
\text { Satire Festival }\end{array}$ & $75,000.00$ \\
\hline & $\begin{array}{l}\text { The } \text { T. Krecu Toša P. Dimčea Festival } \\
\text { of Literature in the Banat Dialect } \\
\text { The Putevi Klasja, International Poetry } \\
\text { Festival }\end{array}$ & $30,000.00$ \\
$\begin{array}{l}\text { The Tibiskus, Cultural-Artistic } \\
\text { Association, Uzdin }\end{array}$ & $\begin{array}{l}\text { The Trebali su ime poneti, Literature } \\
\text { Seminar }\end{array}$ & $95,000.00$ \\
& Meeting of Writers in the Banat Dialect & $30,000.00$ \\
\hline The Doina, Cultural Club, Uzdin & Cultural Week & $20,000.00$ \\
\hline $\begin{array}{l}\text { Festival of Romanian Music and } \\
\text { Folklore of Vojvodina, Uzdin }\end{array}$ & $\begin{array}{l}\text { Festival of Romanian Music and } \\
\text { Folklore of Vojvodina }\end{array}$ & $95,000.00$ \\
\hline
\end{tabular}

402. On tender basis for co-financing of the projects/programmes the quality of which contributes to the development and the presentation of art and culture of national minorities, the Ministry of Culture supported the cultural manifestations related to Ruthenian language.

\begin{tabular}{|c|c|c|}
\hline Beneficiary & Project & Granted Funds \\
\hline Culture Club, Ruski Krstur & $\begin{array}{l}\text { The Crvena Ruža, } 46^{\text {th }} \text { and } 47^{\text {th }} \text { Festival } \\
\text { of Ruthenian Culture }\end{array}$ & $480,000.00$ \\
\hline & $\begin{array}{l}\text { The Kosteljnikova jesen, } 14^{\text {th }} \text { and } 15^{\text {th }} \\
\text { and } 16^{\text {th }} \text { Cultural Manifestation }\end{array}$ & $210,000.00$ \\
\hline
\end{tabular}

403. The Table below contains the data about the funds granted for co-financing of the cultural manifestations related to Ruthenian language according to the individual applications submitted to the tenders issued by the Provincial Secretariat of Culture of AP of Vojvodina.

\begin{tabular}{|l|l|r|}
\hline \multicolumn{1}{|c|}{ Beneficiary } & \multicolumn{1}{c|}{ Purpose } & Granted Funds \\
\hline $\begin{array}{l}\text { The Žetva, Cultural-Artistic } \\
\text { Association, Kucura }\end{array}$ & $\begin{array}{l}\text { The Kucurska Žetva, Festival of } \\
\text { Original Ruthenian Production }\end{array}$ & $180,000.00$ \\
\hline $\begin{array}{l}\text { The Kucura, Cultural-Artistic } \\
\text { Association, Kucura }\end{array}$ & $\begin{array}{l}\text { The Kucurski klip, International } \\
\text { Festival of Humour and Satire }\end{array}$ & $20,000.00$ \\
\hline $\begin{array}{l}\text { The Ruthenian Cultural-Educational } \\
\text { Association, Novi Sad }\end{array}$ & $\begin{array}{l}\text { The Veselinka, } 6^{\text {th }} \text { Festival of } \\
\text { Children's Production }\end{array}$ & $200,000.00$ \\
\hline $\begin{array}{l}\text { The Ruski Krstur, Culture Club, Ruski } \\
\text { Krstur }\end{array}$ & $\begin{array}{l}\text { The Kosteljnikova jesen, } 14^{\text {th }} \text { and } 15^{\text {th }} \\
\text { and } 16^{\text {th }} \text { Cultural Manifestation } \\
\text { The Crvena Ruža, } 46^{\text {th }} \text { and } 47^{\text {th }} \text { Festival } \\
\text { of Ruthenian Culture }\end{array}$ & $650,000.00$ \\
\hline $\begin{array}{l}\text { The Pact Ruthenorum, Association of } \\
\text { Citizens, Ruski Krstur }\end{array}$ & $\begin{array}{l}\text { The Dnjovka, Multimedia Festival of } \\
\text { Young People }\end{array}$ & 6000.00 \\
\hline Association of Ruthenians in Subotica & $\begin{array}{l}\text { The Proleće Dr Mafteja Vinaja, } \\
\text { Cultural Manifestation }\end{array}$ & $60,000.00$ \\
\hline
\end{tabular}


404. On tender basis for co-financing of the projects/programmes the quality of which contributes to the development and the presentation of art and culture of national minorities, the Ministry of Culture supported the cultural manifestations related to Slovak language.

\begin{tabular}{|l|l|r|}
\hline \multicolumn{1}{|c|}{ Beneficiary } & \multicolumn{1}{c|}{ Project } & Granted Funds \\
\hline The Matica Slovačka, Bački Petrovac & Slovak Traditional Festivities 2007 & $70,000.00$ \\
\hline $\begin{array}{l}\text { The Kisač, Cultural-Information- } \\
\text { Educational Centre, Kisač }\end{array}$ & $\begin{array}{l}\text { The Zlatna brana, } 14^{\text {th }} \text { Festival of } \\
\text { Children's Folklore }\end{array}$ & $50,000.00$ \\
\hline The Zvolen, Cultural-Artistic & $\begin{array}{l}\text { Festival of New Slovak Lyric Poems - } \\
\text { Kulpin 2009 }\end{array}$ & $50,000.00$ \\
\hline & $\begin{array}{l}\text { The Susret u pivničkom polju, 42 } \\
\text { Thd and }\end{array}$ & $230,000.00$ \\
The Pivnice, Slovak Cultural-Artistic & $\begin{array}{l}\text { rd } \text { of Solo Singers of Slovak Original } \\
\text { Songs }\end{array}$ & \\
\hline
\end{tabular}

405. Within the tenders issued by the Provincial Secretariat of Culture of AP of Vojvodina the below stated manifestations related to Slovak language were supported.

\begin{tabular}{|l|l|r|}
\hline \multicolumn{1}{|c|}{ Beneficiary } & \multicolumn{1}{c|}{ Purpose } & Granted Funds \\
\hline The Matica Slovačka, Bački Petrovac & Slovak Traditional Festivities & $390,000.00$ \\
\hline $\begin{array}{l}\text { The Kisač, Cultural-Information- } \\
\text { Educational Centre, Kisač }\end{array}$ & $\begin{array}{l}\text { The Zlatna brana, } 14^{\text {th }}, 15^{\text {th }} \text { and } 16^{\text {th }} \\
\text { Festival of Children's Folklore }\end{array}$ & $300,000.00$ \\
\hline $\begin{array}{l}\text { The Zvolen, Cultural-Artistic } \\
\text { Association, Kulpin }\end{array}$ & Festival of New Slovak Lyric Poems & $900,000.00$ \\
\hline $\begin{array}{l}\text { The Mihail Babinka, Cultural Club, } \\
\text { Padina }\end{array}$ & Cultural Festival in Padina & $70,000.00$ \\
\hline $\begin{array}{l}\text { The Heroj Janko Čmelik, Slovak } \\
\text { Cultural-Artistic Association, Stara } \\
\text { Pazova }\end{array}$ & The Tancuj, tancuj, Folklore Festival & $220,000.00$ \\
\hline
\end{tabular}

406. On tender basis for co-financing of the projects/programmes the quality of which contributes to the development and the presentation of art and culture of national minorities, the Ministry of Culture supported the National Council of the Ukrainian National Minority, Novi Sad to organize the Kalina Festival of Ukrainian Culture with 400,000.00 dinars.

407. The Table below contains the data about the funds granted for co-financing of the cultural manifestations related to Ukrainian language according to the individual applications submitted to the tenders issued by the Provincial Secretariat of Culture of AP of Vojvodina.

\begin{tabular}{|l|l|r|}
\hline \multicolumn{1}{|c|}{ Beneficiary } & \multicolumn{1}{c|}{ Purpose } & Granted Funds \\
\hline $\begin{array}{l}\text { The Kalina, Cultural-Artistic } \\
\text { Association, Inđija }\end{array}$ & The Taras Ševčenko Days & $20,000.00$ \\
\hline $\begin{array}{l}\text { The Ivan Senjuk, Cultural-Artistic } \\
\text { Association, Kula }\end{array}$ & The Taras Ševčenko Days & $40,000.00$ \\
\hline $\begin{array}{l}\text { The National Council of the Ukrainian } \\
\text { National Minority, Novi Sad }\end{array}$ & $\begin{array}{l}\text { The Kalina, } 4^{\text {th }} \text { Festival of Ukrainian } \\
\text { Culture }\end{array}$ & $60,000.00$ \\
\hline
\end{tabular}




\begin{tabular}{|l|l|r|}
\hline $\begin{array}{l}\text { The Prosvita, Association for } \\
\text { Ukrainian Language, Literature and } \\
\text { Culture, Novi Sad }\end{array}$ & The Taras Ševčenko Days & $10,000.00$ \\
\hline $\begin{array}{l}\text { The Kozbar, Ukrainian Cultural- } \\
\text { Artistic Association, Novi Sad }\end{array}$ & $\begin{array}{l}\text { An Evening Devoted to the Music and } \\
\text { Works of Ukrainian Poet Lesja } \\
\text { Ukrajinka }\end{array}$ & $20,000.00$ \\
\hline $\begin{array}{l}\text { The Kolomejka, Ukrainian Culture } \\
\begin{array}{l}\text { Fostering Association, Sremska } \\
\text { Mitrovica }\end{array}\end{array}$ & \begin{tabular}{l} 
Festival of Ukrainian Culture \\
\hline
\end{tabular} & \\
\hline
\end{tabular}

408. On tender basis for co-financing of the projects/programmes the quality of which contributes to the development and the presentation of art and culture of national minorities, the Ministry of Culture supported the cultural manifestations related to Croatian language.

\begin{tabular}{|l|l|r|}
\hline \multicolumn{1}{|c|}{ Beneficiary } & \multicolumn{1}{c|}{ Project } & Granted Funds \\
\hline $\begin{array}{l}\text { The Ljutovo, Croatian Cultural Artistic } \\
\text { Association, Ljutovo }\end{array}$ & Month of Culture & $40,000.00$ \\
\hline $\begin{array}{l}\text { The Vladimir Nazor, Croatian } \\
\text { Cultural-Artistic Association, Sombor }\end{array}$ & $\begin{array}{l}\text { The Dužijanca, traditional harvesting } \\
\text { festivity, Sombor 2007 and 2009 }\end{array}$ & $100,000.00$ \\
\hline $\begin{array}{l}\text { The Bunjevačko kolo, Croatian } \\
\text { Cultural Club, Subotica }\end{array}$ & $\begin{array}{l}\text { The Dužijanca 2007, traditional } \\
\text { harvesting festivity, Subotica }\end{array}$ & $150,000.00$ \\
\hline The Hrvatska čitaonica, Subotica & Days of Balint Vujkov & $130,000.00$ \\
\hline The Town Library, Subotica & Meetings with writers from Croatia & $95,000.00$ \\
\hline
\end{tabular}

409. Within the tenders issued by the Provincial Secretariat of Culture of AP of Vojvodina the below stated manifestations related to Croatian language were supported.

\begin{tabular}{|l|l|r|}
\hline \multicolumn{1}{|c|}{ Beneficiary } & \multicolumn{1}{|c|}{ Purpose } & Granted Funds \\
\hline $\begin{array}{l}\text { The Silvije Strahimir Kranjčević, } \\
\text { Croatian Cultural Singing Club, Bački } \\
\text { Breg }\end{array}$ & $\begin{array}{l}\text { Šokačko prelo } \\
\text { Mikini dani }\end{array}$ & $30,000.00$ \\
\hline $\begin{array}{l}\text { The Duukat, Croatian Cultural-Artistic } \\
\text { Association, Vajska-Bođani }\end{array}$ & $\begin{array}{l}\text { Šokačko prelo } \\
\text { In vajska }\end{array}$ & $80,000.00$ \\
\hline $\begin{array}{l}\text { The Matija Gubec, Hungarian Cultural } \\
\text { Singing Club, Ruma }\end{array}$ & $\begin{array}{l}\text { Manifestation of the Matija Gubec } \\
\text { Clubs }\end{array}$ & $30,000.00$ \\
\hline $\begin{array}{l}\text { The Vladimir Nazor, Croatian } \\
\text { Cultural-Artistic Association, Sombor }\end{array}$ & $\begin{array}{l}\text { The Dužijanca, traditional harvesting } \\
\text { festivity }\end{array}$ & $25,000.00$ \\
\hline $\begin{array}{l}\text { The Šokadija, Croatian Cultural } \\
\text { Singing Club, Sonta }\end{array}$ & $\begin{array}{l}\text { Šokačko veče in Sonta } \\
\text { Beчe y CoHTu }\end{array}$ & $30,000.00$ \\
\hline $\begin{array}{l}\text { The Bunjevačko kolo, Croatian } \\
\text { Cultural Club, Subotica }\end{array}$ & $\begin{array}{l}\text { The Dužijanca 2007 } \\
\text { The Matica hrvatska, Subotica }\end{array}$ & $70,000.00$ \\
\hline The Hrvatska čitaonica, Subotica & Days of the Matica hrvatska in Bačka & $46,000.00$ \\
& $6^{\text {th } \text { and } 7^{\text {th }} \text { Festival of Balint Vujkov }}$ & $30,000.00$ \\
\hline & $\begin{array}{l}\text { th } \text { Provincial Festival of Reciters in } \\
\text { Croatian Language }\end{array}$ & $126,000.00$ \\
\hline
\end{tabular}

410. Within the tenders issued by the Ministry of Culture, the projects affirming and promoting multilingual character and multiculturalism were financially supported. The Table below contains the examples of such co-financing. 


\begin{tabular}{|l|l|c|}
\hline \multicolumn{1}{|c|}{ Beneficiary } & \multicolumn{1}{|c|}{ Project } & Granted Funds \\
\hline The Mass Entertainment Group, & The Stari Grad Culture Week 2008 and & $700,000.00$ \\
Association of Citizens, Novi Pazar & 2009 & $650,000.00$ \\
\hline $\begin{array}{l}\text { The Dunavski talasi, Associations of } \\
\text { the Danube Radio Stations, } \\
\text { Smederevo }\end{array}$ & Festival of the Danube Folklore & \\
\hline $\begin{array}{l}\text { The Milan Ajvaz, Cultural-Artistic } \\
\text { Club, Srpski Krstur }\end{array}$ & $\begin{array}{l}7^{\text {th }} \text { festival of Folklore of National } \\
\text { Minorities }\end{array}$ & $150,000.00$ \\
\hline
\end{tabular}

411. Within the tenders issued by the Provincial Secretariat of Culture of AP of Vojvodina, the below stated programmes or projects affirming and promoting multilingual character of Vojvodina were financially supported.

\begin{tabular}{|c|c|c|}
\hline Beneficiary & Purpose & Granted Funds \\
\hline $\begin{array}{l}\text { The Jedinstvo, Cultural Singing Club, } \\
\text { Bajmok }\end{array}$ & $\begin{array}{l}45^{\text {th }} \text { and } 46^{\text {th }} \text { International Folklore, } \\
\text { Bajmok }\end{array}$ & $110,000.00$ \\
\hline $\begin{array}{l}\text { The Dositej Obradović Škola Plus, } \\
\text { Bela Crkva }\end{array}$ & Ethnic Tolerance as Permanent Attitude & $40,000.00$ \\
\hline $\begin{array}{l}\text { Association of Gusle-Players of } \\
\text { Vojvodina, Vrbas }\end{array}$ & $16^{\text {th }}$ Festival of Epic Poetry and Gusle & $50,000.00$ \\
\hline $\begin{array}{l}\text { The Vinogradi, Cultural Club - } \\
\text { Cultural-Artistic Asscociaition, } \\
\text { Gudurica }\end{array}$ & The Zlatna jesen, Ethno festival & $100,000.00$ \\
\hline $\begin{array}{l}\text { The Veljko Vlahović, Development } \\
\text { Association, Zrenjanin }\end{array}$ & The Banatska priča, $2^{\text {nd }}$ Ethno Festival & $40,000.00$ \\
\hline $\begin{array}{l}\text { The Club of Romanians of Kovin, } \\
\text { Kovin }\end{array}$ & $\begin{array}{l}\text { Festival of Traditional Customs with } \\
\text { Serbs, Roma, Hungarians, Romanians, } \\
\text { Czechs and Vlachs }\end{array}$ & $70,000.00$ \\
\hline $\begin{array}{l}\text { Centre of Folk Art and General } \\
\text { Education of Hungarians in }\end{array}$ & $\begin{array}{l}\text { The Upoznajmo jedni druge - series of } \\
\text { interactive lectures on cultural heritage } \\
\text { of ntions living in Novi Sad }\end{array}$ & $220,000.00$ \\
\hline Vojvodina, Novi Sad & $\begin{array}{l}\text { International Folklore Festival of Novi } \\
\text { Sad }\end{array}$ & $325,000.00$ \\
\hline $\begin{array}{l}\text { The Muzička Omladina Vojvodine, } \\
\text { Novi Sad }\end{array}$ & The Muzička priča za decu & $50,000.00$ \\
\hline $\begin{array}{l}\text { The Matija Gubec, Hungarian Cultural } \\
\text { Singing Club, Tavankut }\end{array}$ & $\begin{array}{l}\text { The Deca su ukras sveta, } 12^{\text {th }} \text { Festival } \\
\text { of Folklore for Children }\end{array}$ & $40,000.00$ \\
\hline
\end{tabular}

\subsubsection{Encouragement of access to works produced in minority languages}

412. For sustainability and status of minority languages, it is of extreme importance that the works produced in minority languages become known to large public. In order to accomplish this objective, the projects providing translations of the works produced in minority languages are financially supported in the Republic of Serbia, thus making them accessible to the speakers of not only majority languages but to the speakers of other minority languages as well. On tender basis, for the translations of books written in minority languages to Serbian language or some other minority language, the Provincial Secretariat of Culture of AP of Vojvodina supported the projects mentioned in the Tables below: 
- Language of the original - Hungarian

\begin{tabular}{|c|c|c|c|}
\hline Publisher & Author/Title & $\begin{array}{l}\text { Language } \\
\text { Translation }\end{array}$ & Granted Funds \\
\hline $\begin{array}{l}\text { The Žarko } \\
\text { Zrenjanin Public } \\
\text { Town Library, } \\
\text { Zrenjanin }\end{array}$ & $\begin{array}{l}\text { Ferenc Nemet, Istorija fotografije } \\
\text { Ferenc Feher, Izabrane pesme }\end{array}$ & $\begin{array}{l}\text { Serbian } \\
\text { Serbian }\end{array}$ & $\begin{array}{l}60,000.00 \\
30,000.00\end{array}$ \\
\hline $\begin{array}{l}\text { The Agora, } \\
\text { Zrenjanin }\end{array}$ & $\begin{array}{l}\text { Tibor Deri, Jednouhi ubica i ja } \\
\text { Šandor Marai, Sibad se rvaća kući } \\
\text { Peter Nadaš, Sopstvena smrt }\end{array}$ & $\begin{array}{l}\text { Serbian } \\
\text { Serbian } \\
\text { Serbian }\end{array}$ & $\begin{array}{l}25,000.00 \\
25,000.00 \\
20,000.00 \\
\end{array}$ \\
\hline $\begin{array}{l}\text { The Branislav } \\
\text { Nušić Public } \\
\text { Library, Novi } \\
\text { Kneževac }\end{array}$ & Bogdan Jožef, Szirmok es tovisek & Serbian & $40,000.00$ \\
\hline $\begin{array}{l}\text { The Town } \\
\text { Library, Novi Sad }\end{array}$ & Ferenc Deak, Sova i čizme & Serbian & $70,000.00$ \\
\hline $\begin{array}{l}\text { The Prometej, } \\
\text { Publishing } \\
\text { Company, Novi } \\
\text { Sad }\end{array}$ & Imre Madač, Čovekova sudbina & Serbian & $70,000.00$ \\
\hline $\begin{array}{l}\text { The Adresa, } \\
\text { Publishing } \\
\text { Company, Novi } \\
\text { Sad }\end{array}$ & Alpar Lošonc, Studija o moći & Serbian & $75.000,00$ \\
\hline $\begin{array}{l}\text { The Zadužbina } \\
\text { mreža za slobodu } \\
\text { informacije, } \\
\text { Segedin }\end{array}$ & Lajoš Faro, Neoznačeni grobovi & Serbian & $20,000.00$ \\
\hline $\begin{array}{l}\text { The Subotičke } \\
\text { novine Ltd., } \\
\text { Subotica }\end{array}$ & $\begin{array}{l}\text { Ištvan Ivanji, Istorija Subotice kao } \\
\text { slobodnog kraljevskog grada I 1886, II } \\
\text { 1892. }\end{array}$ & Serbian & $300,000.00$ \\
\hline
\end{tabular}

- Language of the original - Romani

\begin{tabular}{|l|l|l|c|}
\hline Publisher & \multicolumn{1}{|c|}{ Author/Title } & $\begin{array}{l}\text { Language of } \\
\text { Translation }\end{array}$ & Granted Funds \\
\hline $\begin{array}{l}\text { Ромско } \\
\text { удружење } \\
\begin{array}{l}\text { RRomanine Jakha, } \\
\text { Vršac }\end{array}\end{array}$ & $\begin{array}{l}\text { Tradicionalna poezija Roma iz Vršca } i \\
\text { okoline }\end{array}$ & Serbian & $15,000.00$ \\
\hline $\begin{array}{l}\text { Association of } \\
\text { Romani Teachers } \\
\text { of Vojvodina, } \\
\text { Deronje }\end{array}$ & $\begin{array}{l}\text { Rajko Ranko Jovanović, Romske } \\
\text { ptičice }\end{array}$ & Serbian & $20,000.00$ \\
\hline $\begin{array}{l}\text { The RRomanine } \\
\text { pustika, Subotica }\end{array}$ & Alija krasnići, Romske bajke & Serbian & $100,000.00$ \\
\hline
\end{tabular}

- Language of the original - Romanian

\begin{tabular}{|l|l|l|r|}
\hline Publisher & \multicolumn{1}{|c|}{ Author/Title } & $\begin{array}{l}\text { Language of } \\
\text { Translation }\end{array}$ & Granted Funds \\
\hline The Vršac & Jon Luka Karađale, Izgubljeno pismo & Serbian & $70,000.00$ \\
\hline
\end{tabular}




\begin{tabular}{|l|l|l|r|}
\hline $\begin{array}{l}\text { Književna } \\
\text { Opština, Vršac }\end{array}$ & $\begin{array}{l}\text { Konstantin Nojka, Molite se za brata } \\
\text { Aleksandrua }\end{array}$ & Serbian & $75,000.00$ \\
\hline $\begin{array}{l}\text { Kopno Ltd. Novi } \\
\text { Sad }\end{array}$ & Virgil Georgiu, Dvadeset peti čas & Serbian & $30,000.00$ \\
\hline $\begin{array}{l}\text { The Evropa } \text { Fund, } \\
\text { Novi Sad }\end{array}$ & $\begin{array}{l}\text { Katalina Kadinoju, Iz novije rumunske } \\
\text { poezije }\end{array}$ & Serbian & $12,500.00$ \\
\hline
\end{tabular}

- Language of the original - Ruthenian

\begin{tabular}{|l|l|l|r|}
\hline Publisher & \multicolumn{1}{|c|}{ Author/Title } & $\begin{array}{l}\text { Language of } \\
\text { Translation }\end{array}$ & Granted Funds \\
\hline $\begin{array}{l}\text { The Town } \\
\text { Library, Novi Sad }\end{array}$ & Irina Hardi Kovačević, Mesečeve suze & Serbian & $40,000.00$ \\
\hline
\end{tabular}

- Language of the original - Slovak

\begin{tabular}{|l|l|l|r|}
\hline Publisher & \multicolumn{1}{|c|}{ Author/Title } & $\begin{array}{l}\text { Language of } \\
\text { Translation }\end{array}$ & Granted Funds \\
\hline $\begin{array}{l}\text { The Agora, } \\
\text { Zrenjanin }\end{array}$ & $\begin{array}{l}\text { Dušan Dušek, Hladne ruke } \\
\text { Dušan Mitana, Patagonija }\end{array}$ & $\begin{array}{l}\text { Serbian } \\
\text { Serbian }\end{array}$ & $60,000.00$ \\
\hline $\begin{array}{l}\text { The Town } \\
\text { Library, Novi Sad }\end{array}$ & Vićazoslav Hronjec, Čisti utorak & Serbian & $70,000.00$ \\
\hline $\begin{array}{l}\text { The Hlas Ljudu, } \\
\text { Novi Sad }\end{array}$ & $\begin{array}{l}\text { Pavlov Dobšinski, Slovačke narodne } \\
\text { priče }\end{array}$ & Serbian & $60,000.00$ \\
\hline $\begin{array}{l}\text { The Hleba i igara } \\
\text { Art Centre, Stara } \\
\text { Pazova }\end{array}$ & Miroslav Demak, Zodijak & $\begin{array}{l}\text { Serbian, } \\
\text { Hungarian, } \\
\text { Romanian, } \\
\text { Ruthenian }\end{array}$ & $50,000.00$ \\
\hline
\end{tabular}

- Language of the original - Croatian

\begin{tabular}{|l|l|l|r|}
\hline Publisher & Author/Title & $\begin{array}{l}\text { Language of } \\
\text { Translation }\end{array}$ & Granted Funds \\
\hline The Zetna, Senta & Robert Tili, Polumjesec $i$ čekić & Hungarian & $20,000.00$ \\
\hline
\end{tabular}

\subsubsection{Promotion of access of minority languages to works produced in other languages}

413. In order to promote the use of minority languages and enable the speakers of the languages concerned to have access to cultural heritage of the majority population, translations of the works written in Serbian into other languages are also provided in the Republic of Serbia. The Provincial Secretariat of Culture of AP of Vojvodina also issues annual tenders for the translations of books written in Serbian language into minority languages. The Tables below contains examples of such support.

- Translation into Bulgarian language

\begin{tabular}{|l|l|r|}
\hline Publisher & \multicolumn{1}{|c|}{ Author/Title } & Granted Funds \\
\hline Association for Bulgarian & Milorad Gerov, Šareni torbičak & $25.000,00$ \\
\hline
\end{tabular}


Language, Literature and Culture,

Novi Sad

- Translation into Hungarian language

\begin{tabular}{|l|l|r|}
\hline Publisher & Author/Title & Granted Funds \\
\hline The Zetna, Senta & Horvat Oto, Jedan plus jedan & $35,000.00$ \\
\hline
\end{tabular}

- Translation into Romani language

\begin{tabular}{|l|l|r|}
\hline Publisher & \multicolumn{1}{|c|}{ Author/Title } & Granted Funds \\
\hline The Bahtale RRomani, Sombor & Manjika Nikolić, Zbirka pesama & $30,000.00$ \\
\hline The Sunce Kham, Vršac & Dušan Radović, Poštovana deco & $36,000.00$ \\
\hline
\end{tabular}

- Translation into Romanian language

\begin{tabular}{|l|l|r|}
\hline Publisher & \multicolumn{1}{|c|}{ Author/Title } & Granted Funds \\
\hline The Libertatea, Pančevo & Matija Bečković, Vera Pavlodoljska & $25,000.00$ \\
\hline
\end{tabular}

- Translation into Ruthenian language

\begin{tabular}{|l|l|r|}
\hline Publisher & \multicolumn{1}{|c|}{ Author/Title } & Granted Funds \\
\hline $\begin{array}{l}\text { The Dnevnik novine } \text { i časopisi, } \\
\text { Novi Sad }\end{array}$ & $\begin{array}{l}\text { Svetozar Petrović, Ogledi o teoriji } \\
\text { književnosti }\end{array}$ & $70,000.00$ \\
\hline
\end{tabular}

\subsubsection{Encouragement of direct participation of the users of minority languages in provision of the conditions and planning of cultural activities}

414. The Republic of Serbia encourages direct participation of the users of minority languages in provision of conditions and planning of cultural activities. The newly adopted Law on the National Councils of the National Minorities, in Articles 1618 , governs the competences of the national councils of national minorities in the field of culture. The national councils establish cultural institutions to maintain cultural specific properties and national identity of the national minority concerned and exercise the rights and obligations of the founders. The Republic, the Autonomous Province and the unit of local self-government may, either entirely or partially, transfer the founding rights to the national council. The national councils have the power to appoint one member of the board of directors of the institution concerned, give opinions on the proposed members of the board of directors and give opinion in the procedure of appointment of the director of the institution concerned to be established by the national council as an institution of particular importance for preservation of identity of the national minority. The national councils establish the strategy of cultural development of the national minority, prescribe what institutions and manifestations in the field of culture are of particular importance for preservation, promotion and development of specificies and national identity of a certain national minority, propose at least one candidate for the common list of candidates for the election of the National Council of Culture and have other competences in the field of culture. 
415. In practice, through the issuance of annual tenders for co-financing of projects, the Ministry of Culture and the Provincial Secretariat of Culture of AP of Vojvodina ensure direct participation of the users of minority languages in provision of conditions and planning of cultural activities. Also, the national councils of national minorities are active participants in adoption of the final decision on co-financing in each tender procedure.

\subsubsection{Encouragement and provision of cultural activities in the territories different from those where minority languages are not traditionally used}

416. Through the issuance of annual tenders, the Ministry of Culture co-finances the projects ensuring the exchange of cultural activities in the territories different from those where minority languages are not traditionally used. This is mainly about visits of cultural-artistic associations and theatre groups performing in minority languages. The examples of such encouragement are mentioned in the previous paragraphs of this Report. 
4.6.

\author{
Article 14 \\ Trans-National Exchanges \\ Selected paragraphs and sub-paragraphs
}

The Parties undertake:

a) to apply existing bilateral and multilateral agreements which bind them with the States in which the same language is used in identical or similar form, or if necessary to seek to conclude such agreements, in such a way as to foster contracts between the users of the same language in the States concerned in the fields of culture, education, information, vocational training and permanent education;

b) for the benefit of regional or minority languages, to facilitate and/or promote co-operation across borders, in particular between regional or local authorities in whose territory the same language is used in identical or similar form.

\title{
4.6.1. Application of bilateral and multilateral arrangements
}

417. The Republic of Serbia is the Contracting Party to the international multilateral and bilateral agreements, on the grounds of succession, which encourage the use and protection of regional or minority languages. These include, inter alia, bilateral agreements on protection of national minorities, as well as the agreements on cultural and educational co-operation as stated in the Section 3.1.9. of this Report. The Republic of Serbia meets the requirements of the above mentioned agreements in good faith and is willing to conclude new agreements with other interested countries.

\subsubsection{Facilitation and improvement of co-operation between regional and local authorities}

418. In the Section 5.7.2. of the First Periodic Report on the implementation of the Charter, it is stated that the Republic of Serbia does not oppose to international cross border regional and local co-operation and that the co-operation of the competent authorities of AP of Vojvodina and many other local self-governments is accomplished without problems and contributes to good neighbouring relations between the Republic of Serbia and the neighbouring countries.

419. The Provincial Secretariat for Regulations, Administration and National Minorities of AP of Vojvodina have established co-operation with the Government of the Republic of Hungary. This co-operation has been in progress since 2006 and has been implemented in the form of financial donations to the project of the Executive Council of the Autonomous Province of Vojvodina under the title of Affirmation of Multiculturalism and Tolerance in Vojvodina. In 2006 the Ministry of Foreign Affairs of the Republic of Hungary granted the donation 
to the project Affirmation of Multiculturalism and Tolerance in Vojvodina in the amount of 13,028,692.00 dinars or EUR 150,275.00. The co-operation continued in the following years. In 2007 the Government of the Republic of Hungary financially supported the project Affirmation of Multiculturalism and Tolerance in Vojvodina, namely the project Media Campaign in the amount of 1,561,146.00 dinars or EUR 19,031.00, as well as the sub-project Tolerance Cup with 4,720,660.00 dinars or EUR 57,734.00; in 2008 it provided donations for the subprojects Tolerance Cup and Living Together - A Multimedia Exhibition with 4,863,739.00 dinars or EUR 51,606.00; in 2009 it supported by a donation the sub-projects Tolerance Cup and the Zajedno documentary TV series with $5,344,341.00$ dinars or EUR 56,569.00.

420. The Provincial Secretariat for Regulations, Administration and National Minorities of AP of Vojvodina has also accomplished the successful co-operation with the civil sector of the Republic of Hungary. The Šansa za stabilnost, Public Foundation supported financially: the project Affirmation of Multiculturalism and Tolerance in Vojvodina, the sub-project the Role of Territorial Units, National Councils and Civil Organizations in Accomplishment of Stability in A Place - A Community, Conference held in Palić, in 2007, with 2,210,677.00 dinars or EUR 27,871.00; the sub-project Ethno Day, with 2,475,073.00 dinars or EUR 31,978.00. In 2008 this Foundation supported the continuation of the sub-project Ethno Day with EUR 59,890.00.

421. According to the data obtained from the units of local self-government, almost all border local self-governments in the Republic of Serbia accomplish co-operation with towns from the neighbouring countries. The examples of such co-operation are contained in the following paragraphs.

422. The municipality of Kikinda has signed the agreements on international cooperation with the following towns: Nagzdobos, Kiskunfélegyháza, Kondoros and Szolnok from the Republic of Hungary; Silistra from the Republic of Bulgaria; Žilina from the Republic of Slovakia; Jimbolia and Medgidia from the Republic of. These agreements are based on the mutual co-operation of towns in the field of economy, society, culture, sports, education, health care and tourism.

423. In the municipality of Odžaci, two local communities have established international co-operation with places in other countries. The local community of Bogojevo has established co-operation with the local authorities of Ocsen in the neighbouring country, in the Republic of Hungary, in the fields of: local selfgovernment, culture and sports. The local community of Lalic has had cooperation with the town of Mošovce in the Republic of Slovakia since 1968, through the Štefanik, Cultural-Artistic Association and the Panonija, Football Club, and since 2003, when the Charter on Co-operation and Fraternization of the two local communities was signed, this co-operation has been constantly expanding. Each year the inhabitants of these local communities visit each other 
taking turns, and the co-operation has also been established between churches, women's associations, voluntary fire fighting brigades, etc.

424. The municipality of Sečanj has established co-operation with the municipality of Fenj and the town of Temishvar in Romania and Csongrád in Hungary. With the Romanian municipalities, the projects have been implemented in the field of communications, infrastructure, states of emergencies, ecology, as well as educational projects within the project Ljudi s ljudina, concerning the renewal of old craftsmen works. Radio Sečanj and radio Banat link from Temishvar, broadcasting programmes in Serbian language have the national frequency and signed the co-operation agreement. Under the initiative of the local selfgovernment, under the approval of the Republic of Serbia, the Jaša Tomić - Fanj border crossing from transferred from the border crossing of local category into the category of an international border crossing. This will intensify all forms of co-operation (information, economic, co-operation in the fields of ecology, culture and education). Talks on the forms of co-operation have been held with the town of Csongrád in Hungary and it is expected that they will be verified soon.

425. The town of Subotica has established co-operation with the towns from the Republic of Croatia: Osjek - in the field of culture, sports, agriculture and economy; Križevci - in the field of economy and culture and Zagreb - in the field of culture. The co-operation has also been established with the towns from the Republic of Hungary: Szeged, Mórahalom, Győr, Érd, as well as with the local self-governments from Kiskunhalas and Bácsalmás.

426. The signing of the Protocol on Co-operation between the municipality of Šid and the Vukovarsko-Srijemske county in the Republic of Županija is for the purpose of implementation of co-operation in social, economic, cultural and other fields where there are possibilities and mutual interests of the signatories to this Protocol.

427. The following municipalities have also established co-operation: Dimitrovgrad with the local authorities in the neighbouring country of Bulgaria, which is implemented at the cultural, educational, economic levels; Kanjiža with the local authorities in the Republic of Hungary in the field of culture, sports, education, as well as through mutual implementation of the projects in the fields concerned; Plandište with the cross border municipalities in the field of project co-operation. 


\section{SUPPLEMENTS}

\subsection{Supplement of the National Council of the Bosniak National Minority}

\section{INTRODUCTORY NOTES}

Bosniaks are a national community living in the Central Serbia, especially in the region of Sandžak. There is also a considerable number of Bosniaks living in Vojvodina, Belgrade and in the majority of municipalities in Serbia. According to the 2002 census, there are 136,087 of Bosniaks in Serbia, and the majority of this number lives in the municipalities of Novi Pazar, Sjenica, Tutin, Prijepolje, Priboj and Nova Varoš.

The Sandžak Bosniaks are of South Slavic origin and a part of the Bosniak national corpus, Bosnia and Herzegovina being their native country, whereas their national identity and autochthony in the territory of the Republic of Serbia are indisputable and taken for granted.

The Bosniak National Council is the highest representative authority and legitimate representative of the Bosniak national community in the Republic of Serbia. Accomplishment of the rights of the Bosniak national minority is encouraged and exercised through the Bosniak National Council, namely through the National Council of the Bosniak National Minority, which was established in 2003 in Novi Pazar. Accomplishment of the rights of Bosniak national minority in the Republic of Serbia and considerable support in this sense, have started with the activities of the National Council of the Bosniak National Minority, through participation of the international institutions (OESC, EU, CE) and through political action of the representatives of executive power, at both local and national levels.

The Bosniak national community has started accomplishing its rights only after the democratic changes on 5 October 2000. Within this period, the Law on Protection of Rights and Freedoms of National Minorities, the Charter on Human and Minority Rights were adopted and the Framework Convention of the Council of Europe on Protection of the Members of National Minorities and the European Charter for Minority or Regional Languages were ratified, as the two most important documents in the field of international law concerning protection of national minorities. Bosniaks, as a national community, although they were a nation-building and constitutive nation in the former Yugoslavia, found themselves to be in the position to fight for their national rights without anybody's assistance and support and keep space with the level of achievement of minority rights with other minorities, in Vojvodina in particular.

Since 2002, when the First State report on the Implementation of the Framework Convention was submitted to the Council of Europe, up to now, essential steps have been made in the minority policy of the Republic of Serbia. 
Within several previous years, the State of Serbia and its organizations and institutions have made considerable efforts to improve and promote the status and the rights of the Sandžak Bosniaks in the Republic of Serbia.

The Bosniak National Council is of the opinion that more complete and more comprehensive accomplishment of the minority rights of the Sandžak Bosniaks in the Republic of Serbia is possible through strengthening of the mechanism of their application at the central, regional and local levels, as well as through co-ordinated action of all representatives, organizations and institutions of the Sandžak Bosniaks at the state level.

\section{CURRENT STATUS OF ACCOMPLISHMENT OF THE RIGHTS OF THE BOSNIAKS}

\section{Official Use of Bosnian Language and Script}

By the ratification of the European Charter for Regional or Minority Languages at the Parliament of the State Union on 21 December 2005, Bosnian language was verified as one of 10 minority languages in Serbia.

Mother tongue of the Sandžak Bosniaks, Bosnian language and script are officially used in the municipalities of Novi Pazar, Tutin, Sjenica and Prijepolje. In spite of existence of all legal grounds, the local authorities in Priboj have been refusing for several years already to make it official and introduce the official use of Bosnian language and script into the statute of the municipality. In the municipality of Nova Varoš, Bosniaks live in a considerable percentage so the official use of Bosnian language in this municipality would be of particular importance.

Court and administrative proceedings before the local courts have not been conducted in Bosnian language and script yet.

In case of issuance of personal documents (passport, identity cards, driving licences), orthography and tradition of mother tongue and script of the Bosniaks are not complied with.

Writing of public names of streets, squares, parts of dwelling areas, local and state authorities and agencies and of names of toponyms and traffic signs is neither in accordance with the provisions of the Law on Official Use of Language and Script, nor with the Law on Rights and Freedoms of National Minorities. In the municipality of Tutin, this right has been applied to a considerable extent, while in other municipalities, in spite of the fact that Bosnian language had been introduced into official use, this right is not exercised and complied with.

More complete and more efficient accomplishment of the right to officially use Bosnian, as mother tongue and as one of the essential elements of the national identity of the Sandžak Bosniaks, is possible if it is made official in all the municipalities and towns of 
the Republic of Serbia where the Sandžak Bosniaks live in considerable percentage, pursuant to the law.

\section{Education in Bosnian Language as Mother Tongue}

Concerning the issue of introduction of Bosnian language into the school system and its treatment, based on the provisions of the Law on Protection of Rights and Freedoms of National Minorities, Bosniaks have started, under great resistance of the state authorities, to exercise the right to education in their mother tongue only at the beginning of the second half of the 2004/2005 school year, with much efforts and under still considerable resistance of some nationalistic conservative circles, political parties and academic circles. For the time being, Bosniaks exercise this right with two classes weekly of Bosnian language with elements of national culture as an optional subject at primary schools in the municipalities of Novi Pazar, Tutin and Sjenica only and at one school in Prijepolje.

There is no teaching of Bosnian language at pre-school institutions in the Republic of Serbia or in the territories where Bosniaks live in a larger number. At pre-school institutions founded by the State, the language of the majority nation is used (Serbian) although the percentage of Bosniak children at these institutions in Novi Pazar, Tutin and Sjenica even reaches $90 \%$.

Concerning secondary education, there is no organized teaching in Bosnian language in the Republic of Serbia. As for the university education, since November 2006 at the State University in Novi Pazar the mixed Department of Bosnian and Serbian Language has been established.

In the territory of the Republic of Serbia, the state authorities arranged no study of history and culture in Bosnian language.

In order to ensure equal treatment in the field of education, it is necessary that the State, through its mechanisms, ensures and provide the teaching in Bosnian language to the members of the Bosniak national minority in primary and secondary education in the units of local self-government where Bosnian language is officially used, pursuant to the law, according to the Model of Education for the Sandžak Bosniaks in the Republic of Serbia, as an official document of the Bosniak National Council.

The State is also obliged to ensure that the textbooks are made for teaching in Bosnian language, according to the adopted Model.

In order that this right is also exercised in the municipalities of Priboj and Nova Varoš, the Bosniak National Council requires the competent local and regional authorities in the Republic of Serbia to introduce Bosnian language into official use as well.

\section{Information in Bosnian Language as Mother Tongue}


In 2008 the Ministry co-financed the weekly informative newspaper in the Bosnian language - the Sandžačke novine, an independent weekly, but not to the extent as in case of some other national communities.

In 2009 the Ministry co-financed the weekly Sandžačke novine with almost $30 \%$.

The State adopted no adequate provisions in order that radio broadcasting companies offer programmes in Bosnian language. The State Public Radio Broadcasting Agency (RTS) has no second of programme in Bosnian language.

The Bosniak National Council requires the competent state authorities to stop discriminating Bosnian language in the public information media.

The State of Serbia is obliged to ensure that the Sandžak Bosniaks have necessary conditions for information in Bosnian language as their mother tongue, through cofinancing and improving the circumstances in the field of printed media and publishing industry, more adequate representation in the programmes of the Public Radio Broadcasting Agency by establishing a special editorial office in Bosnian language with this Agency, as well as through co-financing of a special production with the Bosniak National Council, which would broadcast its own programmes in local and regional media.

In order to secure more adequate information at the regional level, the Bosniak National Council stresses as necessary the need to redefine the existing radiobroadcasting areas in Serbia so that the area of six Sandžak municipalities where the Sandžak Bosniaks are concentrated in the largest percentage will be classified into one radiobroadcasting area, and not in two as so far. The Republic Radio Broadcasting Agency (RBA) stipulated no frequency to be granted to the media broadcasting programmes in Bosnian language.

\section{Protection of Cultural Heritage}

Immovable cultural goods of the Republic of Serbia in the municipalities of Novi Pazar, Tutin, Sjenica, Nova Varoš, Prijepolje and Priboj are another very important issue. The State of Serbia and its authorities and institutions have not so far undertaken necessary measures and activities, nor built adequate mechanisms to ensure more complete protection of the Bosniak cultural heritage. Consequently, there is an ongoing devastation of the Bosniak cultural heritage, it is being destroyed and programmes and measures for its protection by the existing institute for protection of monuments are not properly applied.

In order to secure its equal treatment, it is necessary that the State of Serbia, its representatives, institutions and other bodies treat all immovable cultural goods of the Sandžak Bosniaks as the cultural heritage of the Bosniaks, and to define it, accept it and treat it as such. 
In order to protect the Bosniak cultural heritage more properly, it is necessary to adopt urgently the programme of measures to protect and improve this heritage.

All the governments constituted so far have had a selective approach to the issue of protection and preservation of the cultural heritage of the Sandžak Bosniaks. The Bosniak National Council finds that preservation of cultural heritage of the Bosniaks is not only good for the Bosniak community but for the State as a whole.

There is a trend of appropriation of the cultural heritage of the Bosniaks, especially of musical tradition, national clothes, kitchen, architecture and other cultural specificies of the Sandžak Bosniaks by other nations and there are attempts to present these elements of the Bosniak culture and tradition as a part of the culture and tradition of the other.

In the territory of six municipalities where the Bosniaks live, the Bosniak National Council established eight buildings or localities witnessing on the history and culture of the Bosniak national community, which should be protected under the support of the State as priorities. These are the Isa-beg Turkish Bath, the Amir-aga Tavern and the $15^{\text {th }}$ Century Tower in Novi Pazar, the Gluhavica archaeological site in Tutin, the ambiance Spahović's House in Sjenica, the Musala in Prijepolje, the medieval Bosnian standing tomb-stones near Priboj and the Mejtaš monument in Nova Varoš.

Within the several previous years, the State of Serbia, through the Ministry of Culture cofinanced the traditional national manifestations of the Sandžak Bosniaks, implemented by the Bosniak National Council (Festival of the Sandžak Songs - FES, festival of the Bosniak Folklore Dance - SBONI and the Sandžak Literature Manifestation-SAKS), as well as several other projects in the field of culture and approved several projects of nongovernmental organizations and associations, as recommended by the Bosniak National Council.

In 2007 the Ministry of Culture co-financed the Bošnjačka riječ, a magazine in culture and social life of the Sandžak Bosniaks, as a quarterly magazine.

In 2009 there was no co-financing of the Bošnjačka riječ magazine by the Ministry of Culture.

In 2009 the Ministry of Culture provided almost no support for any of the projects of the Bosniak National Council in the field of culture, while the funds very granted to nongovernmental organizations and associations for the projects financed for the national minorities without asking for the opinion of the Bosniak National Council.

\section{Effective Participation in Public Life}

The Sandžak Bosniaks participate in the public life of the Republic of Serbia in a still unsatisfactory way. There is no state strategy for the inclusion of minorities in all structures and their possible inclusion is more the result of political arrangements and 
coalitions, depending on the current interest of the elites in power, frequently to the detriment of national minorities and their interests.

In order to achieve more complete national equality in the field of participation in public life, the Sandžak Bosniaks must also be provided, in addition to representation in the National Assembly and in the Government of the Republic of Serbia, with adequate representation in judiciary, police and other institutions, organizations and institutions at all power levels, in accordance with the European standards and proportionally to their participation in population.

The basic form of employment of the Bosniaks is still in the private sector. Representation of the Bosniaks in the state administration, except for the units of local self-government, is at a very low level and it does not even approximately correspond to the national structure of the population. In this respect the status is particularly bad with the Ministry of Internal Affairs, where the Bosniaks make irrelevant percentage at police administrations and police stations. University educated Bosniaks, who had gained their education out of the Republic of Serbia, and who qualified to work with the police, have no opportunities to get jobs in police service, due to the reasons that cannot be explained and that are not grounded on law, thus being absolutely discriminated in relation to the members of other nationalities.

A large number of university educated Bosniaks of all professions is registered with the Employment Agency and have no clear or certain perspectives and future.

Based on the official information, the percentage of representation of the Bosniaks at the state institutions in towns where the Bosniaks make the majority is considerably lower in relation to the percentage of the total share in the population.

In the towns where the Bosniaks make the minority, there is a very low percentage of representation at the state authorities. The composition in the police, judiciary, education, health care and other institutions of the republic has not been balanced yet, where the Bosniaks have no share according to their share they have in the structure of local communities or at the level of the Republic.

The State institutions, such as the Police, the District Court, the District Public Prosecution Office, the Municipal Public Prosecution Office, the Municipal Misdemeanour Authority, the tax Administration in Novi Pazar, the Electricity Distribution Company, PTT, Telekom, etc. are still inaccessible to a large extent for the Bosniaks to get employment with them. For example, out of the total number of employees at the Police in Novi Pazar, there are only 30\% of the Bosniaks, although the members of the Bosniak national community make more than $80 \%$ of the total population. Likewise, there is an inadequate structure of employees with the judicial authorities, too, at the Tax Administration, where there are about 50\% of the employed Bosniaks. Also, in Novi Pazar, there is an inadequate structure of employees and there is no opportunities for the employment of the Bosniaks, in spite of the existence of all 
required conditions and qualifications (required level of education) and the things are the same at the state institutions and authorities in Tutin, Sjenica and Prijepolje.

\section{Economic Status}

The region where the Sandžak Bosniaks were concentrated in the largest number in all state communities used to be one of most underdeveloped regions. The things are the same at present, too.

According to the official data, in 2005 in 6 Sandžak municipalities in Serbia, the road network was built in the percentage of only $10 \%$ in relation to the average in Serbia. Novi Pazar, as the town where the Bosniaks live in the largest number in the Republic of Serbia has no railway line, although there is an expressive need to have it due to economic and all other reasons.

All large investments and all capital projects have so far missed Sandžak and among economic branches there is predominance of low profit industries, such as light textile industry. Although it has exceptional natural advantages and potentials in respect of development of agricultural industry, this region is not proportionally developed and the state investments in it were not adequate and in relation to other regions where the members of the national minorities live the investments were insignificant.

The investments in utilities, sports, school, health, telecommunication and other buildings and infrastructure were at rather low level and they do not meet the requirements of the population, for which reason there is constant uncertainty among the Bosniaks, which results in ongoing migrations, together with unconsolidated political factor.

In order to overcome the neglect and underdevelopment for many decades, it is necessary for the State of Serbia to actively encourage and intensify economic development of the region of Sandžak, through all its available mechanisms and institutions of the system making significant investments in the Sandžak municipalities, especially in the field of infrastructure, and in order to achieve more equal regional development and for the harmonization of our country with the standards of the European Union.

\section{Decentralization}

The region where the Sandžak Bosniaks are predominantly concentrated has always been administratively divided into different administrative areas. According to the latest administrative division of the Republic of Serbia to districts, Novi Pazar and Tutin are within the Raška District, and Sjenica, Prijepolje, Nova Varoš and Priboj are within the Zlatibor District.

The branch offices of many state institutions and their organization do not meet the requirements of the local population and aggravate the accomplishment of their fundamental human rights to a large extent. For example, the inhabitants of the municipality of Sjenica must go to the Health Centre in Užice for certain health services, 
which is the regional health centre, although Novi Pazar is twice nearer and there they may get health services much easier and without additional expenses for travelling and accommodation.

The members of the Bosniak national minority are traditionally orientated towards Novi Pazar, and the population of the entire region has been within the same administrative area for centuries, which kept the name of Sandžak.

For all these reasons, in order to ensure the maximum efficient and effective accomplishment of the minority rights of the Sandžak Bosniaks, it is necessary to make conditions, both according to the Constitution and law, that in the process of decentralization and regionalization, namely in the process of new territorial organization of the Republic of Serbia, the towns of Novi Pazar and the municipalities of Tutin, Sjenica, Nova Varoš, Prijepolje and Priboj be within one region.

\subsection{Supplement of the National Council of the Bunjevac National Minority}

Nowadays the Bunjevac are the autochthonous population of Vojvodina the origin of which is still subject to many opposing opinions.

The Bunjevac have migrated and settled in the territory of the present Serbia, namely of Vojvodina, in the course of the $16^{\text {th }}$ and the $17^{\text {th }}$ centuries. The largest migrations were in 1686 from the regions of Lika, Dalmatinska zagora, Dalmatia and Herzegovina, which were not constituted as states at that time. After they had come to this territory, they settled in three towns: Subotica and Sombor and in their surroundings and in the town of Baja, which today belongs to the Republic of Hungary. These places present the cultural and historic centres of the Bunjevac.

According to the official statistical data about the history of the $20^{\text {th }}$ century and at the beginning of the $21^{\text {st }}$ century, the following numbers of the Bunjevac were registered in these areas:

- 43,832 persons in 1931 ;

- 21,434 persons (only in Vojvodina) in 1991 and in other parts of Serbia they were not officially registered;

- 20,012 persons in total in 2002, of whom 19,766 persons in Vojvodina and 246 persons in the Central Serbia.

There are further more Bunjevac in the territory of Vojvodina than the above mentioned numbers, but the Bunjevac exercised their democratic right and declared themselves to be either Croatians or Yugoslavs in 1991 as well as in 2002. This relates to the territories of the towns of Subotica and Sombor.

We claim this on the grounds of the data on numerous families from our surroundings, where, for example, in Subotica, big families such as Dulić, Stantić, Vuković, Skenderović, or in Sombor, families Parčetić, Matarić, Bošnjak, Patarčić, declare 
themselves to be the members of the Bunjevac national community, that is some of them, and the other declare themselves to be the members of the Croatian national community.

Not going into the details of the political or some other dimension of this fact, in spite of an enormous progress the Bunjevac have achieved within the last 7 years since the time the institution of the National Council of the Bunjevac National Minority, there is still the need to stress bad or unacceptable status of accomplishment of the mentioned four constitutional and legal rights of the Bunjevac and the relevant problems to make efforts to analyze an adequate model of resolution of certain problems.

The Statute of Vojvodina clearly establishes that the Bunjevac is an independent national minority. However, in practice, and in particular in the territory of Subotica and Sombor it is still said, especially by the Croatian national minority that the Bunjevac are an ethnic group of the Croatian nation, as well as that the Bunjevac speech with elements of national culture, which is taught as an optional subject in the first four classes of the primary school, is a dialect of the Croatian language.

The documents you have received indicate that the process of standardization of the Bunjevac speech has started. However, this process was started more seriously only in 2009. The implementation of this task was set up in the project including, in addition to the representatives of the Bunjevac from these two towns, the professors of the Faculty of Philology from Novi Sad and the Institute of Balkan Studies from Belgrade. The project will be completed in 2012, and the preparation of the grammar and orthography of the Bunjevac language will follow. It is only then it can be expected that the Bunjevac language as a standard language of the Bunjevac population will be ratified.

Financing of activities of the cultural institutions for the Bunjevac national minority has been slightly improved in relation to the First Report.

However, since the Bunjevac only have the state of Serbia to back them up, applications for financial recourses are to be submitted according to the same criteria as for other national communities having their mother countries, meaning that the Bunjevac do not have an equal status in the Republic of Serbia.

There are still certain difficulties when submitting tender documentation for financing of publishing and information activities. National minorities having their own mother tongue officially used have the priority in financing, while the Bunjevac are underprivileged because the Bunjevac language has not been standardized yet and, therefore, it is not officially used.

The financing of teachers of the Bunjevac as an optional subject, which optional teaching is carried out at 11 primary schools with 171 pupils attending the teaching of this optional subject, two classes a week, namely 72 classes annually, is explicitly provided from the funds of the National Council of the Bunjevac National Minority. This problem has not been resolved yet for the reason that teaching is carried out in one class of the school 
concerned, and these classes are not included in the monthly fund of classes carried out by the teachers for the payment of salaries.

Managers of primary schools do not pay sufficient importance to this optional subject on the occasion of enrolment of children, especially in the surroundings where the Bunjevac, and where there are grounds for the attendance of this teaching and for its expansion as well. At present the managers of schools in the above mentioned surroundings mainly belong to Croatian national minority, and exercising their right of affiliation they favour the enrolment of children into Croatian classes, while the enrolment of children to attend classes of the Bunjevac speech with elements of national culture is of secondary importance or neglected.

The relations among the Bunjevac national minority at the local level in the town of Subotica have been improved, because the Bunjevac party of Vojvodina has a representative in the Town Assembly, so the decisions of the Town Assembly may be far more influenced concerning the funds or the rights related to the Bunjevac. However, this is not sufficient because the town of Sombor has no representative in the Town Assembly belonging to the Bunjevac national minority.

In the towns of Subotica and Sombor where the Bunjevac declaring themselves only as the Bunjevac or as the Croatians live, the marking of cultural manifestations has not been defined yet, such as the Dužijanca - harvesting festivity. The Dužijanca is the tradition present with the Bunjevac for more than one hundred years as a public manifestation, also being one of the national holidays of the Bunjevac national minority at the same time (out of four recognized holidays). However, the Dužijanca has been traditionally presented as the harvesting festivity of the Bačka Croatians, and it is organized by the Bunjevačko kolo, Croatian Cultural Centre.

The same is with the marking of the Dan velikog Prela - on 2 February every year, which was adopted by the Bunjevac as their national holiday, and the Bačka Croatians mark it as a holiday of the Croatian national community (the Croatians in Subotica and Sombor).

We underline the above two examples as one of the main elements of attempts to assimilate the Bunjevac national minority into the Croatian national minority. The funds for these manifestations are also provided by the town of Subotica and Sombor, the budget of AP of Vojvodina and the budget of the Republic of Serbia.

This phenomenon has a negative impact on inter-ethnic relations in the subject two towns, so it is necessary to eliminate it by making a final distinction between these two national communities, that is, there are the Bunjevac national minority and the Croatian national minority, and disclaimer or assimilation of one minority into another must be prohibited by law.

In respect of information, this Report contains positive results, in case of both the monthly issue of the Bunjevačke novine and the Tandrčak, supplement for children. However, there are still problems in the sphere of information by the public media - the 
Radio Subotica local station and by radio and television information for the Bunjevac national minority in general.

The financing of the Bunjevačka rič radio programme is accomplished with the funds of the National Council of the Bunjevac National Minority, through a provisions editorial office. The editorial office prepares a radio programme of half an hour, which is broadcasted once a week via the Novi Sad II Radio, on Fridays from 9.30 p. m. to 10.00 p. m. This time is very bad fro listeners, in particular because it cannot be listened to in Subotica at all. It can only be listened to in Sombor and Bačka Topola. The Radio Subotica local station has radio programmes in Serbian, Hungarian, Croatian and German languages, while no programme is provided for the requirements of the Bunjevac. The problem of the lack of standardization of the Bunjevac language is constantly quoted, although it is the obligation of the local self-government pursuant to the law to also provide information to those national minorities having their own language within the frame of the speech only.

The television programme for the Bunjevac national minority is prepared in the duration of half an hour only twice a month by the Public Radio Broadcasting Agency of Vojvodine, which is not satisfactory, and in this area the problem of the official use of the language is also stressed, and the Bunjevac is not a language yet.

The members of the Bunjevac national minority have not made significant progress in employment, either, in relation to the Report submitted in 2007. This problem also exists in politics, where political parties make agreements on employment of their members at key positions in the towns of Subotica and Sombor, too. No care is taken about the structure of the members of the Bunjevac national minority, whose share in the town of Subotica amounts to over $11 \%$, which should be governed by adequate legal provisions and not by the will of political parties.

An attempt of the Bunjevac national minority in the Republic of Hungary to accomplish their minority self-government in 2008 was not successful, so we propose that the State of Serbia ensures the protection of the members of this national minority through its activities, namely that an adequate aid is rendered to a new attempt, which has now been in progress in the neighbouring country of Hungary.

It may be generally concluded that the State of Serbia renders positive assistance to the Bunjevac national minority in accomplishment of its rights guaranteed by the Constitution and the law in the field of the rights addressed in this Report. However, we have stated some still pressing problems on the way to accomplish essential rights of the Bunjevac, for which reason this supplement is submitted as a review and we ask the State to intervene, in order to preserve national identity of the Bunjevac on permanent grounds.

\subsection{Supplement of the National Council of the Romanian National Minority}

According to the 2002 census, there are 34,576 citizens of the Republic of Serbia who declared themselves as members of the Romanian national minority. 30,419 citizens of 
this number live in AP of Vojvodina and 4,157 of them in Central Serbia including the City of Belgrade. Members of the Romanian national minority live in the entire territory of AP of Vojvodina and in North-East Serbia. The biggest number of the members of the Romanian national minority live in the municipalities of South Banat, where there are 21,618 citizens who are the members of the Romanian national minority or in percents, in the Municipality of Alibunar there are around $30 \%$ or 6,000 Romanians and in the Municipality of Vršac there are around $11 \%$ or 6,000 Romanians.

The Romanian national minority is one of the traditional minorities in this area which has built educational, cultural, informative, religious and other institutions, as well as its own tradition in these areas.

\section{EDUCATION}

Education in Romanian language in this area has a tradition that lasts more than a century.

At primary schools in Vojvodina, the teaching in Romanian as instruction language is carried out in 9 municipalities at 13 eight-year schools, of which three schools are detached classes and at 14 four-year schools. Of 13 eight-year schools in total, at 5 of them the teaching is only performed in Romanian language (the dwelling places of Kuštilj, Grebenac, Barice, Lokve and Nikolinci) and 8 of them are mixed schools (Vršac, Alibunar, Seleuš, Vladimirovac, Banatsko Novo Selo, Torak, Ečka and Uzdin).

At secondary schools the teaching in Romanian as instruction language is performed at 2 schools and in 2 municipalities, namely in Vršac and Alibunar. Besides primary and secondary schools, there is the Higher School for Education of Pre-School Teachers in Vršac, the Teacher Training Faculty - Belgrade (Department of Vršac) and two Departments of Romanian Studies at the Faculties of Philosophy in Belgrade and Novi Sad.

In the 2009/2010 school year, at primary schools where the teaching is carried out in Romanian language, there were 1,266 pupils enrolled and at secondary schools there were 238 pupils enrolled. One of the biggest problems of the Romanian national minority is the decrease in the number of inhabitants which results in the decrease in the number of pupils as well. Many parents enrol their children, especially from the mixed marriages into classes where the teaching is carried out in Serbian language, many have moved to towns or abroad and dispersion made an impact, too. Accordingly, there are only around $60 \%$ of children of Romanian Nationality who attend eight-year school in their mother tongue.

For pupils who declared themselves to be Romanians and who attend school in Serbian language, mother tongue with elements of national culture as an optional subject has been introduced. All national councils propose that this subject is introduced into teaching as a compulsory subject and not as an optional subject. 
The schools lack teachers in the following subjects: history, geography, mathematics, chemistry, physics, biology, English language. In order to resolve this problem, the National Council of the Romanian National Minority granted scholarships to insufficient teachers and with two schools it signed employment contracts for teachers upon the completion of education (one of these contracts is already enforced at the primary school in Tork. We have also proposed to the Ministry of Education of Romania to grant better scholarships a sa stimulus, to the Romanian students from Serbia to study the relevant subjects in Romania. Unfortunately, we received no response from them. We expect that the Mixed Commission will be more efficient.

At schools where the teaching is carried out in Romanian language, the major problems are: textbooks, attendance registries, registry books, certificates, pupils' books, competition test papers and seminars for professional training of teachers, class teachers and secondary school teachers.

The schools do not receive textbooks on time and they are more expensive than the textbooks in Serbian language. The Ministry of Education of the Republic of Serbia approved the use of textbooks from the native country but these textbooks may only be used auxiliary textbooks for teachers and pupils.

Attendance registries are bilingual and for this reason they are three times more expensive than the attendance registries in Serbian language, and the Institute of education also delivers attendance registries to schools with delay of two or even three months after the commencement of the school year. The same is with the registry books, certificates, pupils' books and test papers for qualification exam in Romanian language and mathematics in the eighth grade.

The problem that occurred in 2009 concerns rationalization of the school system. Regardless of the political statement of the Minister of Education that rationalization shall not be carried to the detriment of teaching in minority languages, the decision was adopted to merge classes at the primary school in Kuštilj (II and IV grades) due to the smaller number of interested pupils. In spite of the decision of the National Council of the Romanian Minority that the primary school in Kuštilj is of particular importance for the Romanian national minority, that its development is sustainable, as well as that it will mark its 100th anniversary in 2011, which data were submitted to the Ministry of Education, the Ministry sent no reply. The merger of classes is the first step to school closing. On the other hand, the Ministry of Education has had a request for independent operations of the primary school in Tork for three years. Neither any positive nor negative replies were received concerning this school.

The adoption of the Law on Pupils' and Students' Standard is a good example of the lack of partnership relations with the Ministry of Education. In the draft of the above mentioned law, the powers of the national councils prescribed by the Law on the National Councils of the National Minorities were derogated. 
The Book of Rules on Ongoing Professional Training and Qualifications of Teachers, Pre-School Teachers and Expert Associates (the Official Gazette of RS, nos. 14/2004 and $56 / 2005$ ) prescribes that ongoing professional training and qualifications of teachers, preschool teachers and expert associates is implemented according to special programmes, which might be optional and compulsory (Article 4) and that a teacher, pre-school teacher and expert associate are obliged to attend at least 100 classes of the programmes in 5 years' time, as follows: at least 60 classes from the list of compulsory classes and up to 40 classes from the list of optional programmes (Article 10). Since only one seminar was organized for the teachers and secondary school teachers in Romanian language, we expect that this problem will be resolved through the Mixed Commission of Serbia and Romania, and that seminars from Romania will be accredited with the Ministry of Education.

\section{ADMINISTRATIVE AUTHORITIES AND PUBLIC SERVICES}

The Romanian language is in official use in 9 municipalities, namely: Alibunar, Bela Crkva, Kovin, Kovačica, Sečanj, Zrenjanin, Žitište, Plandište and Vršac as well as in the place of Banatsko Novo Selo in the Municipality of Pančevo.

Traditional names of the places in Romanian language where the Romanian language is in official use are not respected. This in particular tackles the towns, which, except of Zrenjanin, do not also have names in Romanian language.

In the municipality of Plandište the name of the municipality is not also written in Romanian language.

In the municipality of Sečanj, the name of the municipality and the name of the only place with Romanian inhabitants, Sutjeska, are not written also in Romanian language. In the municipality of Bela Crkva, the name of the municipality is not also written in Romanian language. In the municipality of Žitište, the name of the municipality is not also written in Romanian language, as well as in the municipality of Kovin.

In the municipality of Kovačica, the name of the municipality is not also written in Romanian language. In the place of Uzdin, where the members of the Romanian national minority live, road signs are written in Serbian and English languages! In the municipality of Alibunar, the names of places Nikolinci and Vladimirovac are not also written in Romanian language and the name of the municipality is written in the same way as in the Serbian language.

Names of streets, squares and other toponyms are not also written in Romanian language in any of the municipalities where the Romanian language is in the official use. (In some places, such as Torak, Uzdin, etc., there are still names of streets written in Romanian language, as the leftover from the Eighties of the last century). Except for the buildings of the Municipal Assemblies, it is rare that the institutions established by the municipality have multilingual signs. 
The members of the Romanian national minority are not proportionally present in the republic bodies, as well as in the bodies of local self-government. In 2006, the Government of the Republic of Serbia adopted the Conclusion on measures for the increase of share of the members of national minorities at the bodies of the state administration, by which it shall directly and through its competent authorities and services undertake permanent measures to increase the share of the members of the national minorities in civil services. The conclusion should have been implemented in cooperation with the Personnel Management Agency, but nothing has been done about it. There is no report on the implementation of this Conclusion, or the national councils of national minorities may not have received it. At present no member of the Romanian national minority is employed with the Ministry of Human and Minority Rights, or any Romanian speaker.

Translation pools do not exist at the levels of the Republic or municipalities where the Romanian language is officially used, namely, there is no option to apply to the authorities in Romanian language. AP of Vojvodina is an exception because there applications may also be submitted in Romanian language.

On the occasion of appointment of judges and prosecutors in the Republic of Serbia, the National Council established that the constitutional and legal provisions on an adequate representation of the members of the Romanian national minority were not properly complied with (Article 77 of the Constitution of RS and Article 46 of the Law on Judges). No member of the Romanian national minority was appointed a judge at the Magistrate Court in Vršac, and in Zrenjanin neither at the Magistrate nor at the Higher Court, and there are no members of the Romanian national minority with the Prosecution Office, either. It is also similar at the level of AP of Vojvodina. The National Council is of the opinion that there are experts who fulfil all the relevant conditions for the appointment.

The adoption of the Law on the National Councils of the National Minorities made a significant step forward in legal regulations and a stable ground for further activities. The basic problem of the implementation will be to accept partner relations with the competent ministry (it exists at present) as well as with the ministries dealing with the issues of minorities, such as the Ministry of Culture, the Ministry of Education, the Ministry of Youth and Sports, the Ministry of Local Self-Government, namely the activities of the Council of the Republic of Serbia fro National Minorities. Financing of the activities of national councils is an important component of this (in 2010 financing will be reduced because another four new national councils are being established and the funds were not increased in relation to 2009, either, not even for the inflation percentage). The resources of the Budgetary Fund for National Minorities are symbolic this year, namely no major project may be financed from these funds of each national minority.

\section{PUBLIC INFORMATION MEANS}

Tradition initiated at the end of the 19th century and at the beginning of the 20th century in particular, resulted in the fact that the Romanians are nowadays the minority leaders, 
in respect of the local printed media. Almost every villages has its own periodicals or other publications. It also applies to the majority of the Romanian organizations.

The main problem of them is how to resolve systematic financing. Modest funds are obtained from the local communities, the National Council of the Romanian National Minority and from other sponsors.

The founding rights of the Libertate, Newspaper Publishing Institution from Pančevo have been transferred to the National Council of the Romanian National Minority. The Executive Council of Vojvodina still co-finances publishing of the Libertate, weekly newspaper, but small or no funds are allocated for publishing, as well as for the Lumina, periodical in literature, art and culture.

The programme in Romanian language is broadcasted by the Public Broadcasting Agency - RTV Vojvodina. On television there is an increase of programmes (duration of programmes) but there no adequate personnel training and technical equipment.

Audibility and viewing of programmes in Romanian language is extremely bad, so that the programmes cannot be properly watched in the South Banat, or two thirds of the Romanian population cannot watch it or listen to it. Radio Television of Vojvodina does not fully perform the function of the public agency of citizens because neither the signal nor the contents of programmes cover the territory concerned.

There is one private radio channel and one private television (RTV Viktorija from Vršac) broadcasting daily programme in Romanian language only. In addition to this programme, the programmes in Romanian language are also broadcasted by TV Pančevo, TV Kovačica and TV Banat from Vršac. Some other local televisions also broadcast programmes in Romanian language, either within paid periods (wedding parties, other parties - TV Lav from Vršac) or on the grounds of projects, such as TV Kladovo, TV Santos Zrenjanin. Private radio stations broadcast programmes in Romanian language for two hours daily (Radio Far Alibunar) or for one hour weekly, and there are several of them. Their basic problem is the scope and the quality. The request to obtain frequency was exactly grounded on the idea to also broadcast programmes in the languages of national minorities.

Information in Romanian language is also affected by transition Serbia is going through. The field of information have the most important role in this period. Intolerance and conflicts on ethnic grounds are also caused by ignorance and because of the lack of information, and not only the information media in minority languages, but also the information media in majority languages have the objective to incite tolerance, cooperation and establishment of mutual confidence in building of a multi-ethnic society.

Solutions to be adopted in this area may not be partial but systematic and just.

\section{CULTURAL ACTIVITIES AND ADVANTAGES}


In the domain of cultural manifestations in the territory of Vojvodina, there are very many of them and they are organized by various associations or institutions of the Romanians. It often happens that within one calendar year the dates of two similar or different manifestations coincide. It is the same with the Romanians, all cultural manifestations, including the largest ones, such as the Major Festival of Romanian Folklore from Vojvodina-Serbia or the Theatre festival of the Romanians suffer from the lack finances to organize cultural contents. Partial solutions are not sufficient. In addition to budgetary subsidies, there are always appeals to additional sponsors and donators, but the bad feeling of begging at all times remains.

As regards the conditions of the buildings of cultural institutions, in some places they are in good or in satisfactory conditions and in some places they are in very bad or warn out conditions. Naturally, things are much better in places where adequate cultural clubs had been built than in the places where the buildings are old and not adapted in time. Technical equipment is very rare. Due to the lack of financial resources and personnel as well, village libraries are closed, except for the libraries in Banatsko Novo Selo, Tork, Kovin and Alibunar, which are open from time to time.

Non-governmental organizations are especially active in organizing cultural manifestations, which are, as a rule, always a step forward in definition of the cultural concept of the Romanians of Serbia, and also in respect of numerous manifestations they organize.

In the field of publishing of books and magazines, things with the Romanians in Vojvodina are slightly better. In addition to the Libertatea from Pančevo, there are another four publishing companies. More than 50 periodicals are published, so almost every village has its own newspaper, and the village of Torak publishes 5 magazines.

The Department in Romanian language of the Sterija National Theatre from Vršac, as a professional theatre, which is financed from the provincial budget, has two premier theatre performances annually, but it is necessary that it has its co-ordinator and at least two actors who will be permanently employed with it.

We have proposed to the Ministry of Culture of the Republic of Serbia to purchase a part of books to be delivered to the libraries all over Serbia thus improving their book stocks, on one side, and to ensure a portion of funds to the publishers for new editions, on the other. We have also proposed that it co-finances the activities of the professional theatre in Romanian language. Our proposals have not been accepted.

The establishment of the Institute of Culture of the Romanians of Vojvodina, which is cofounded by the Assembly of AP of Vojvodina and the National Council of the Romanian national Minority, means the appearance of a new cultural scientific institutions of Romanians.

The newly established National Orchestra of the National Council of the Romanian national Minority is a new phenomenon on the Romanian cultural scene, which already 
proved to be a true place where talented people meet and also the place of already distinguished musicians contributing a lot by its concerts to the affirmation of Romanian folk music, folklore and numerous performers and singers.

It is necessary that in future this Orchestra, as well as the Choir of the National Council of the Romanian National Minority have better working conditions and obtain systematic financing.

In other fields of cultural-artistic activities, there are problems, weak points (galleries, village orchestras do not have some instruments, lack of professional choreographers, lack of funds to produce theatre performances, etc.). However, efforts are made to overcome such problems by enthusiasts who are present in almost all communities who give necessary positive attitudes in the field of culture and art of the Romanians of Serbia. We expect a lot from the Mixed Commission in this field, too.

\section{TRANSNATIONAL EXCHANGE}

Although in 2003 a bilateral agreement on protection of minorities has been signed between Serbia (then Serbia and Montenegro) and Romania and it has been ratified by the respective Parliaments one year later, the Mixed Commission has been only established few months ago, but it has not yet started its work. We expect the most of this Commission in solving the problems in the areas of education, culture and information particular. 